UNIVERSIDADE DE SÃO PAULO

FACULDADE DE FILOSOFIA, CIÊNCIAS E LETRAS DE RIBEIRÃO PRETO DEPARTAMENTO DE PSICOLOGIA

LEPPS - Laboratório de Ensino e Pesquisa em Psicologia da Saúde

Av. Bandeirantes, 3900, Monte Alegre, 14040-901, Ribeirão Preto - SP

Fone (0xx16) 33153645

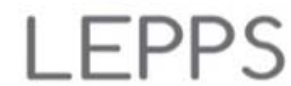

Laboratório de Ensino e Pesquisa em Psicologia da Saúde

FFCLRP.USP

\title{
Das (im)possibilidades do feminino: A sexualidade de mulheres com transtornos alimentares na perspectiva das adolescentes, suas mães e seus pais
}

Carolina Leonidas

Tese apresentada à Faculdade de Filosofia, Ciências e Letras de Ribeirão Preto da USP, como parte das exigências para a obtenção do título de Doutor em Ciências.

Área de concentração: Psicologia

Ribeirão Preto - SP 



\section{Das (im)possibilidades do feminino: A sexualidade de mulheres com transtornos alimentares na perspectiva das adolescentes, suas mães e seus pais}

Tese apresentada à Faculdade de Filosofia, Ciências e Letras de Ribeirão Preto da USP, como parte das exigências para a obtenção do título de Doutor em Ciências.

Área de concentração: Psicologia

Orientador: Prof. Dr. Manoel Antônio dos Santos 
Autorizo a reprodução e divulgação total ou parcial desta Tese, por qualquer meio convencional ou eletrônico, para fins de estudo e pesquisa, desde que citada a fonte.

\section{FICHA CATALOGRÁFICA}

\section{Leonidas, Carolina}

Das (im)possibilidades do feminino: A sexualidade de mulheres com transtornos alimentares na perspectiva das adolescentes, suas mães e seus pais. Ribeirão Preto, 2016.

323 p.: il. ; $30 \mathrm{~cm}$

Tese de Doutorado apresentada à Faculdade de Filosofia, Ciências e Letras de Ribeirão Preto, Universidade de São Paulo - USP. Área de concentração: Psicologia.

Orientador: Santos, Manoel Antônio dos.

1. Transtornos alimentares. 2. Feminilidade. 3. Sexualidade.

4. Família. 5. Psicanálise. 
Leonidas, Carolina

Das (im)possibilidades do feminino: A sexualidade de mulheres com transtornos alimentares na perspectiva das adolescentes, suas mães e seus pais

Tese apresentada à Faculdade de Filosofia, Ciências e Letras de Ribeirão Preto da USP, como parte das exigências para a obtenção do título de Doutora em Psicologia.

Aprovado em:

Banca Examinadora

$\operatorname{Prof}(\mathrm{a}):$ Instituição:

Julgamento: Assinatura:

Prof(a): Instituição:

Julgamento: Assinatura:

Prof(a): Instituição:

Julgamento: Assinatura:

Prof(a): Instituição: Julgamento: Assinatura:

Prof(a): Instituição:

Julgamento: Assinatura: 

Apoio financeiro:

Esta Tese de Doutorado recebeu o apoio da Fundação de Amparo à Pesquisa do Estado de São Paulo - FAPESP, com a concessão de bolsa de doutorado de maio de 2013 julho 2016 (Processo número 2012/23854-2).

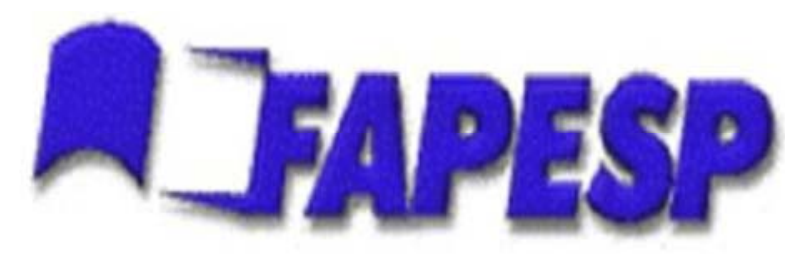



Todo ser humano do sexo feminino não é, portanto, necessariamente mulher; cumpre-lhe participar dessa realidade misteriosa e ameaçada que é a feminilidade. Não se nasce mulher, torna-se mulher.

Simone de Beauvoir, O Segundo Sexo 



\section{AGRADECIMENTOS}

Ao Prof. Dr. Manoel Antônio dos Santos, pelo exemplo como profissional e pesquisador em Psicologia, que me possibilitou tanto crescimento e aprendizado ao longo dos nove anos em que estivemos trabalhando juntos, desde minha Iniciação Científica. Só tenho a agradecer pelo acolhimento proporcionado desde 2007, pelo compromisso e envolvimento demonstrados em cada etapa de minha formação acadêmica e por sua incansável dedicação à formação de novos pesquisadores. Espero que este tenha sido mais um de muitos trabalhos que ainda nascerão de nossa fecunda parceria como pesquisadores no campo da Psicologia Clínica e da Psicologia da Saúde.

Aos membros do Grupo de Assistência em Transtornos Alimentares (GRATA - HCFMRP-USP): Profa. Dra. Rosane Pilot Pessa Ribeiro, Prof. Dr. José Ernesto dos Santos, Dra. Érika Arantes de Oliveira-Cardoso, Dra. Vivian M. M. Suen, Dra. Tatiana Rezende, Dra. Marina Manochio Pina, Élide Dezoti Valdanha Ornelas, Lílian Regiane de Souza Costa, Ana Paula, Daniela e estagiárias de Psicologia e de Nutrição, por iluminarem o meu conhecimento e tornarem menos árduo o meu trabalho com um tema tão complexo como os transtornos alimentares, e por terem me proporcionado a oportunidade da rica convivência com uma equipe que realmente trabalha de forma multi e interdisciplinar.

Aos membros do Laboratório de Ensino e Pesquisa em Psicologia da Saúde (LEPPSFFCLRP-USP-CNPq), pelo intenso intercâmbio semanal de experiências e conhecimentos, fundamentais para a consolidação de minha trajetória como pesquisadora.

À Profa. Janet Treasure, Ph.D., por ter me orientado durante o período de Doutorado Sanduíche no Institute of Psychiatry, Psychology and Neurosciences da King's College London. Seu vasto conhecimento e sua maneira cuidadosa de lidar com os alunos me possibilitaram uma amplitude imensurável de aprendizado e momentos preciosos em Londres, que levarei para toda a vida.

Aos membros da Eating Disorders Unit - IoPPN, King's College London, por terem me recebido no laboratório e colaborado com minha pesquisa.

Ao Bruno Palazzo Nazar, cuja amizade e coorientação durante o período que passei em Londres fizeram toda a diferença para que eu tirasse o máximo de proveito da experiência. Desde o apoio acadêmico até as dicas de lugares para visitar e quais restaurantes frequentar, sua presença foi indispensável. Em meio a tanto frio, encontrei um amigo com a warmth que eu precisava, e que só os brasileiros sabem oferecer. Obrigada. 
Ao Prof. Dr. Lazslo Antônio Ávila, por ter colaborado com o desenvolvimento desta pesquisa com discussões de casos em eventos científicos, com o envio de textos e com a exposição de aulas sempre enriquecedoras. Seus escritos e suas falas são inspiradoras.

Ao Prof. Dr. Fábio Scorsolini-Comin, por ser um exemplo de pessoa, profissional e pesquisador. Sua participação no meu progresso profissional e acadêmico é imensurável, obrigada pela disposição de me ajudar a crescer.

À Élide Dezoti Valdanha Ornelas, minha "Migs”, por ser minha melhor amiga, sócia, colega de trabalho e de pós-graduação. Obrigada por estar sempre ao meu lado, desde as colaborações acadêmicas e profissionais até os momentos mais importantes da minha vida pessoal. Você é para sempre.

Ao Mário Augusto Tombolato "Plaucius", por ter entrado no LEPPS como colega de Doutorado, e ter se tornado um grande amigo.

À Lilian Regiane de Souza Costa, pela amizade e parceria na vida acadêmica e na vida pessoal.

Às amigas Débora, Manoela, Tatá, Olívia, Lizandra, Carina, Luciane, Tayline, Denise e Tatiana, cujas amizades tornam a minha vida mais leve. Obrigada por nunca deixarem que eu me sentisse sozinha.

À minha família: minha mãe, Ana Maria, por ser meu exemplo de feminilidade. Por me mostrar que mulheres podem ser sensíveis e fortes, carinhosas e firmes, trabalhadoras e “família”, mães e mulheres. Ao meu pai, João, por nunca ter poupado esforços para nos oferecer tudo de melhor, e por ser essa pessoa marrenta tão manteiga. Aos meus irmãos Mariana e Fábio, por me trazerem alegria nos dias difíceis, e também nos dias felizes. São vocês que dão sentido à minha existência. Amo vocês, do tamanho do céu.

À Fundação de Amparo à Pesquisa do Estado de São Paulo - FAPESP, pela concessão de bolsa de Doutorado e bolsa BEPE, pelo apoio financeiro que foi primordial para a realização desta pesquisa e pelo aval científico que esse suporte representa.

Ao Leandro Barbosa Novo, pela caprichosa confecção da arte gráfica da capa e dos diagramas de categorias temáticas desta Dissertação.

Por fim, agradeço a todos que, de alguma maneira, direta ou indireta, colaboraram para a realização deste estudo. 


\section{RESUMO}

Leonidas, C. (2016). Das (im)possibilidades do feminino: A sexualidade de mulheres com transtornos alimentares na perspectiva das adolescentes, suas mães e seus pais. Tese de Doutorado, Faculdade de Filosofia, Ciências e Letras de Ribeirão Preto, Universidade de São Paulo.

Os transtornos alimentares (TAs) são caracterizados como graves perturbações no comportamento alimentar, que podem resultar em prejuízos biológicos, psicológicos e sociais. A prevalência é substancialmente maior no sexo feminino e os sintomas eclodem predominantemente na adolescência, coincidindo com a transição psicossocial que marca essa etapa do ciclo vital e a intensificação das vivências sexuais. Sob a ótica da psicanálise, os TAs podem ser compreendidos como respostas somáticas a estados de tensão emocional desencadeados por processos mentais que não puderam ser simbolizados. Essa dificuldade de simbolização parece estar relacionada à impossibilidade da adolescente se individuar, o que necessitaria da assunção de um corpo e uma mente de mulher adulta. A fusão psíquica e decorrente angústia de separação em relação à figura materna também estão relacionadas com as representações inconscientes da feminilidade: a irrupção da sexualidade na adolescência leva a menina a vivenciar um luto pela perda do corpo infantil que, assim como os pais da infância, está sendo deixado para trás. Partindo-se da hipótese de que o sintoma da recusa alimentar pode ser considerado como uma defesa inconsciente utilizada para obliterar o processo de separação-individuação, que é parte inerente ao desenvolvimento emocional, o presente estudo teve por objetivo investigar o desenvolvimento da sexualidade e da feminilidade em mulheres que desenvolveram TAs, na perspectiva das pacientes, de suas mães e de seus pais, buscando estabelecer relações entre esses aspectos fundamentais da constituição subjetiva e os sintomas que caracterizam o quadro psicopatológico. Trata-se de um estudo de caso coletivo, descritivo e transversal, com enfoque qualitativo. As participantes eram adolescentes e jovens adultas com TAs, vinculadas ao Grupo de Assistência em Transtornos Alimentares (GRATA) do Hospital das Clínicas da Faculdade de Medicina de Ribeirão Preto da Universidade de São Paulo (HC-FMRP-USP), e seus respectivos pais (casal parental, entrevistados em separado), totalizando sete tríades edípicas. Os instrumentos utilizados para a coleta dos dados foram: roteiro de entrevista semiestruturada, aplicada individualmente com cada membro da tríade; diário de campo, elaborado pela pesquisadora após as entrevistas; e Critério de Classificação Econômica Brasil/2015. As entrevistas foram gravadas em áudio para posterior transcrição e análise temática. Os dados foram interpretados com o apoio do referencial teórico da psicossomática psicanalítica de Joyce McDougall. Os resultados demonstraram que a dinâmica psíquica das tríades era marcada por fusão entre mãe e filha, e distanciamento afetivo do pai. A feminilidade era vivenciada tanto pelas filhas quanto pelas mães como equivalente à vulnerabilidade, tornando-se fonte de angústias. Para os genitores do sexo masculino, a feminilidade das filhas foi vivenciada como ameaçadora, suscitando afastamento entre pai e filha na época da puberdade. Evidenciou-se dificuldades, por parte das filhas, no acesso à genitalidade, que guarda relação com a dificuldade no processo de individuação e separação em relação aos pais da infância. Os achados proporcionam insumos para a prática clínica no que concerne à articulação entre as vivências relacionadas à sexualidade/feminilidade e a precipitação e manutenção dos sintomas de TAs, proporcionando uma compreensão mais abrangente dos aspectos psicológicos por parte dos profissionais envolvidos na assistência, prevenção e promoção de saúde na adolescência.

Palavras-chave: transtornos alimentares, sexualidade, feminilidade, relações familiares, psicanálise. 



\begin{abstract}
Leonidas, C. (2016). The (im)possibilities of the feminine: Sexuality of women with eating disorders from the perspective of female adolescents, their mothers and their fathers. $\mathrm{PhD}$ thesis, Faculdade de Filosofia, Ciências e Letras de Ribeirão Preto, Universidade de São Paulo.
\end{abstract}

Eating disorders (ED) are characterized by severe disturbances in eating behavior, which may result in biological, psychological and social prejudices. Prevalence is significantly higher in female gender and symptoms start mainly during adolescence, coinciding with the psychosocial transition that marks this stage of vital cycle and the intensification of sexual experiences. From the perspective of psychoanalysis, ED can be understood as somatic responses to emotional tension triggered by mental processes that could not be symbolized. This difficulty of symbolization seems to be related to the adolescent's impossibility to individuate, which would require an adult's woman body and mind. Psychic fusion and the resulting anxiety from separation of the mother figure is also related to the unconscious representations of femininity: the eruption of sexuality in adolescence leads the girl to grieve for her child body, and also her child's parents, which are being left behind. Starting from the premise that the symptom of food refusal may be regarded as an unconscious defense used to obliterate the process of separation-individuation, which is an inherent part of emotional development, the present study aimed to investigate the development of sexuality and femininity in women who developed ED, from the perspective of patients, their mothers and their fathers, seeking to establish links between these fundamental aspects of subjective constitution and the symptoms that characterize the psychopathological condition. It is a collective case study, descriptive and cross-sectional, with qualitative approach. Participants were female adolescents and young adults with ED, linked to the Group of Assistance on Eating Disorders (GRATA), from the Clinics Hospital of the Faculty of Medicine of Ribeirão Preto, University of São Paulo (HC-FMRP -USP), and their parents (parental couple, interviewed separately), totalizing seven oedipal triads. The instruments used for data collection were: semi-structured interviews, applied individually with each member of the triad consisting of daughter-mother-father; field diary, prepared by the researcher during data collection; and Brazilian Economic Classification Criterion/2015. Interviews were audiorecorded for later transcription and thematic analysis. Data was be interpreted with the support of the theoretical framework of Joyce McDougall's psychoanalytic psychosomatic. Results showed that the triads' psychic dynamic included mother-daughter fusion, and father's detachment. Mothers and daughters perceived femininity as equivalent to vulnerability and source of distress. Fathers were frightened by their daughters' femininity, which made them distance themselves. Daughters' difficulties regarding reaching genitality was evident, and was associated with difficulties of individuation and separation from the parents from childhood. This study provides input into clinical practice with regard to the relationship between the experiences related to sexuality/femininity and symptoms of ED, providing a more comprehensive understanding of the psychological aspects related to sexuality by the professionals involved in care, prevention and health promotion in adolescence.

Keywords: eating disorders, sexuality, femininity, family relations, psychoanalysis. 



\section{LISTA DE TABELAS}

Tabela 1. Caracterização das participantes segundo dados antropométricos

Tabela 2. Caracterização das participantes segundo dados sociodemográficos

Tabela 3. Caracterização dos pais das pacientes segundo idade, escolaridade, profissão/ocupação, situação conjugal, número de filhos e renda familiar aproximadas.

Tabela 4. Definição das classes econômicas a partir da distribuição da pontuação no CCEB/15 e renda média domiciliar no ano de 2015 ... 



\section{LISTA DE FIGURAS}

Figura 1. Mapa de associação de ideias da família Moraes................................................. 108

Figura 2. Mapa de associação de ideias da família Batista ................................................... 129

Figura 3. Mapa de associação de ideias da família Paiva..................................................... 155

Figura 4. Mapa de associação de ideias da família Garcia................................................... 177

Figura 5. Mapa de associação de ideias da família Teixeira ................................................ 193

Figura 6. Mapa de associação de ideias da família Ribeiro.................................................. 207

Figura 7. Mapa de associação de ideias da família Freitas................................................... 226

Figura 8. Mapa de associação de ideias confeccionado a partir da análise das entrevistas

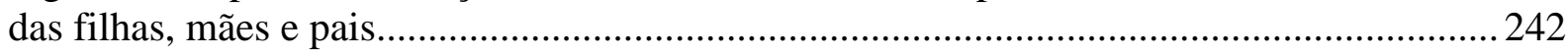





\section{LISTA DE SIGLAS}

AN

BEPE

BN

ABEP

ABA

ABIPEME

ANEP

CCEB

CEP

CFNI

COREQ

DSM

ED

EDI

FAPESP

FFCLRP

FRCP

FRCPsych

GRATA

HC-FMRP

IMC

IoPPN

LEPPS

MANTRA

OBE
Anorexia Nervosa

Bolsa de Estágio de Pesquisa no Exterior

Bulimia Nervosa

Associação Brasileira de Estudos Populacionais

Associação Brasileira de Anunciantes

Associação Brasileira dos Institutos de Pesquisa de Mercado

Associação Nacional de Empresas de Pesquisa

Critério de Classificação Econômica Brasil

Comitê de Ética em Pesquisa

Conformity to Feminine Norms Inventory

Consolidated Criteria for Reporting Qualitative Research

Diagnostic and Statistical Manual of Mental Disorders

Eating Disorders

Eating Disorders Inventory

Fundação de Amparo à Pesquisa no Estado de São Paulo

Faculdade de Filosofia, Ciências e Letras de Ribeirão Preto

Fellow of the Royal College of Physicians

Fellow of the Royal College of Psychiatrists

Grupo de Assistência em Transtornos Alimentares

Hospital das Clínicas da Faculdade de Medicina de Ribeirão Preto

Índice de Massa Corporal

Institute of Psychiatry, Psychology and Neurosciences

Laboratório de Ensino e Pesquisa em Psicologia da Saúde

Maudsley Model of Anorexia Nervosa Treatment for Adults

Order of the British Empire 
PHD

SLAM

TA

TCC

TCLE

USP
Philosophiae Doctor (Doctor in Philosophy)

South London and Maudsley NHS Foundation Trust

Transtornos Alimentares

Terapia Cognitivo Comportamental

Termo de Consentimento Livre e Esclarecido

Universidade de São Paulo 


\section{SUMÁRIO}

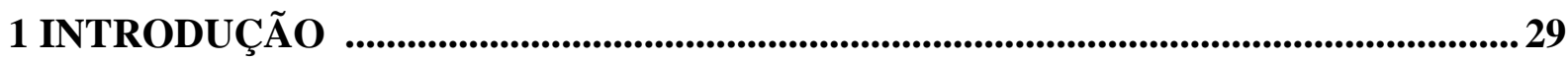

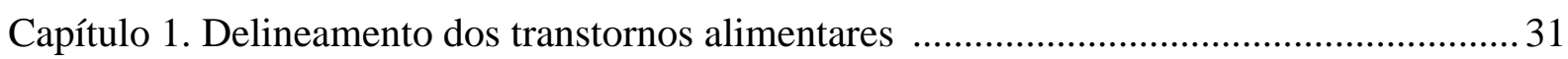

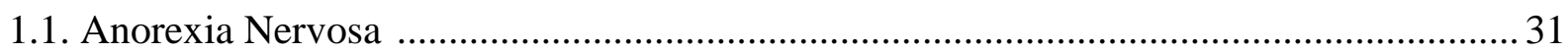

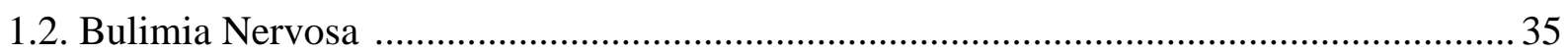

Capítulo 2. Marco teórico: Os transtornos alimentares sob a ótica da psicanálise .................. 40

2.1. A relação mãe-filha nos transtornos alimentares .......................................................... 44

2.2. A função paterna na família e na constituição da identidade dos filhos .......................... 49

Capítulo 3. Sexualidade e psicanálise ................................................................................... 53

3.1. O devir da feminilidade: a sexualidade feminina à luz da psicanálise ...........................56

Capítulo 4. Transtornos alimentares e sexualidade: Análise da produção científica ..............64

Capítulo 5. Feminilidade: o desenvolvimento da sexualidade feminina e a maternidade ........ 76

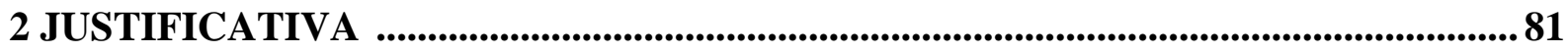

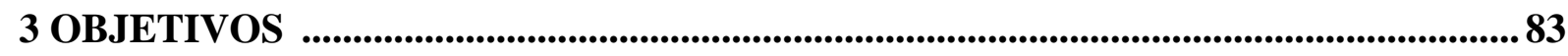

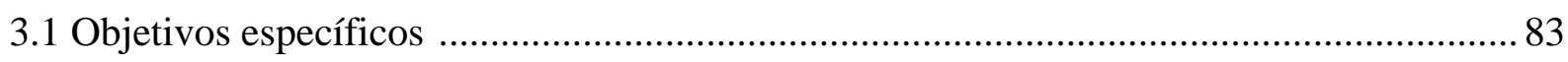

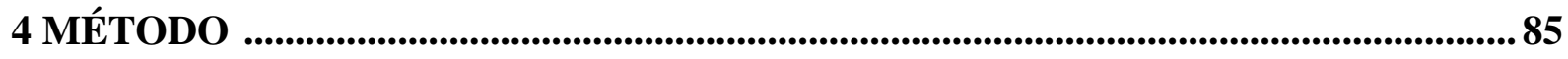

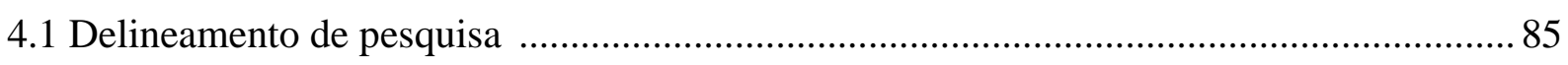

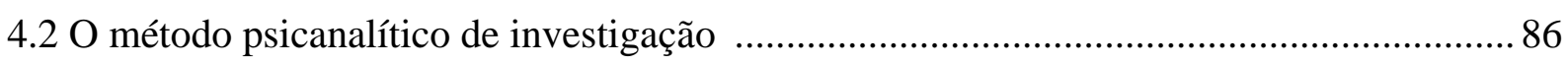

4.3 COREQ, Domínio I: Grupo de pesquisa e reflexão ..................................................... 89

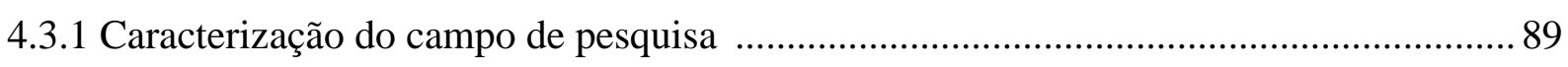

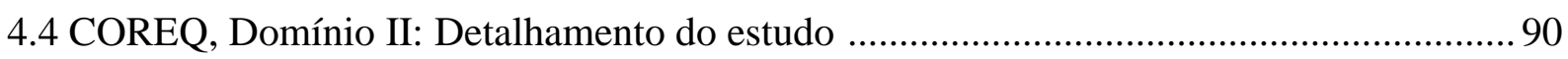

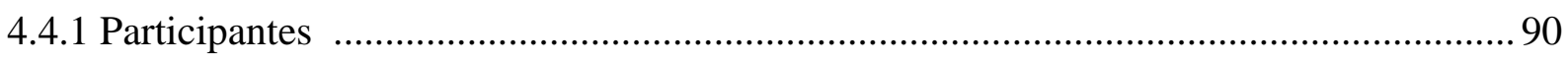

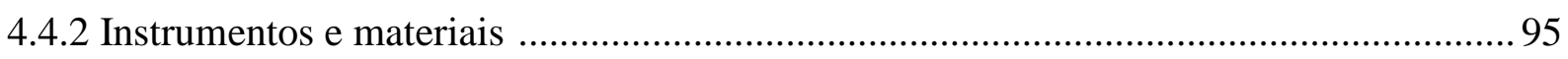

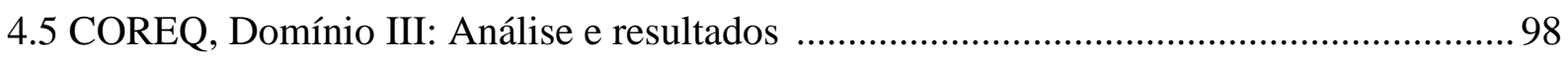

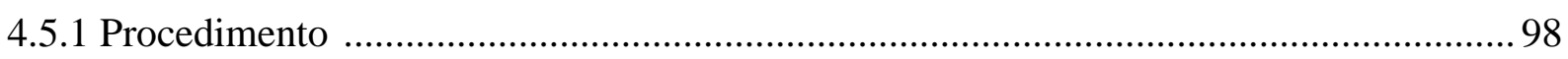

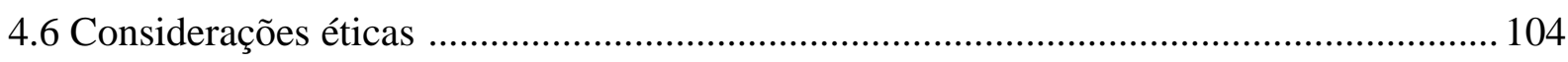

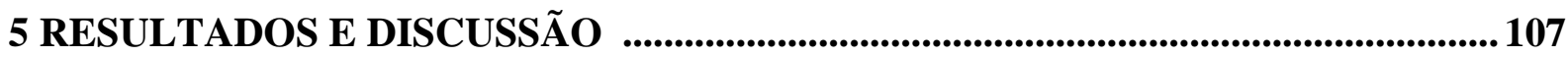

5.1 Eixo I - Análise vertical dos dados: A singularidade da experiência em família ............ 108 


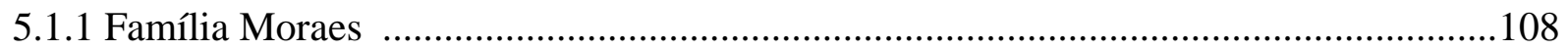

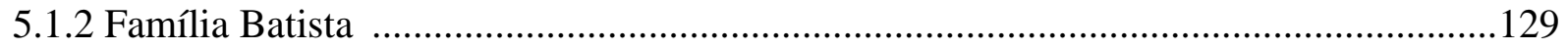

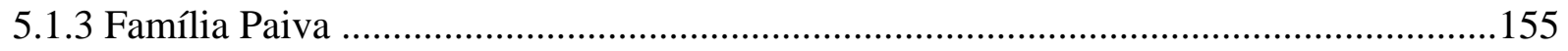

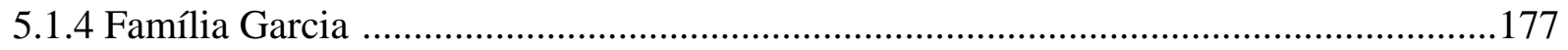

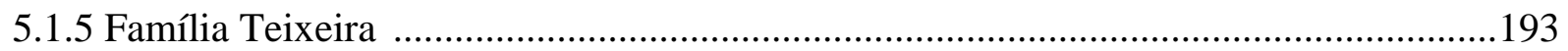

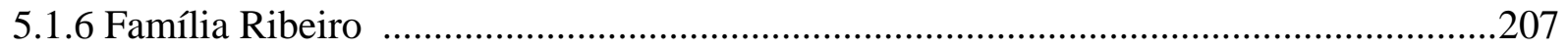

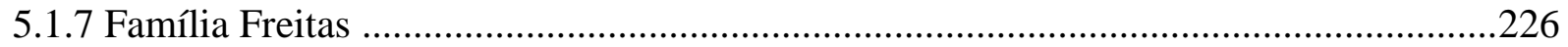

5.2 Eixo II - Análise horizontal dos dados: Síntese integrativa das experiências vivenciadas

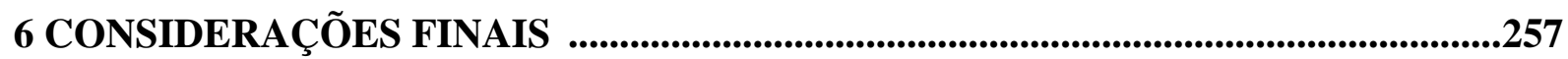

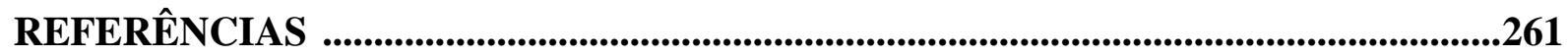

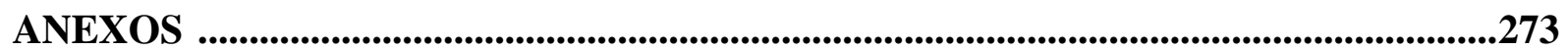

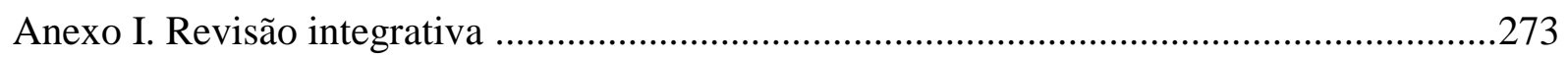

Anexo II. Autorização formal do coordenador do GRATA para realização da pesquisa .......305

Anexo III. Critério de Classificação Econômica Brasil 2015 ................................................306

Anexo IV. Carta de aceite do Comitê de Ética em Pesquisa FFCLRP-USP .........................309

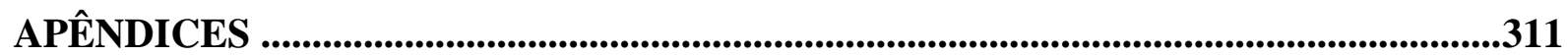

Apêndice I - Roteiro de Entrevista Semiestruturada PACIENTES ……................................311

Apêndice II - Roteiro de Entrevista Semiestruturada MÃES E PAIS ...................................313

Apêndice III - Termo de Consentimento Livre e Esclarecido (ACIENTES acima de 18

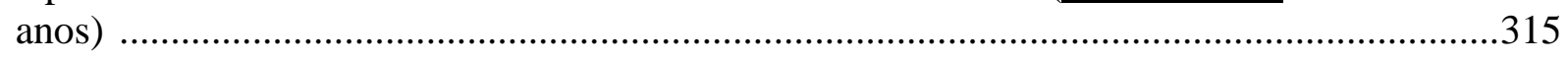

Apêndice IV - Termo de Consentimento Livre e Esclarecido (pais ou responsáveis legais

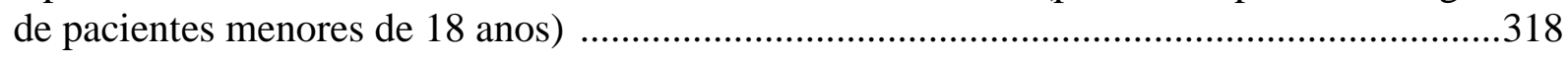

Apêndice V - Termo de Consentimento Livre e Esclarecido (MÃES E PAIS) .....................321 


\section{PREÂMBULO}

O delineamento desta pesquisa derivou da intersecção de histórias pessoais, profissionais e científicas, dentre as quais destaco, inicialmente, a minha inserção como voluntária em um serviço de assistência a pacientes com diagnóstico de transtornos alimentares (TAs) para realização de uma pesquisa de Iniciação Científica, com apoio da FAPESP (processo número 2008/50869-5). Este estudo, intitulado: Imagem corporal e atitudes alimentares de pacientes com anorexia nervosa, foi realizado sob a orientação do Prof. Dr. Manoel Antônio dos Santos e marcou meu ingresso no Laboratório de Ensino e Pesquisa em Psicologia da Saúde - LEPPS (FFCLRP-USP-CNPq).

Esse percurso inaugural na vida acadêmica teve continuidade com minha Dissertação de Mestrado, desenvolvida junto ao Programa de Pós-Graduação em Psicologia da Faculdade de Filosofia, Ciências e Letras de Ribeirão Preto (FFCLRP-USP), sob a orientação do Prof. Dr. Manoel Antônio dos Santos. Além disso, a continuidade de minha participação como psicóloga da equipe multidisciplinar também desempenhou papel crucial na escolha do tema desta tese.

Minha inserção no Grupo de Assistência em Transtornos Alimentares (GRATA) do Hospital das Clínicas da Faculdade de Medicina de Ribeirão Preto (HC-FMRP-USP) se deu no ano de 2007, como pesquisadora em nível de Iniciação Científica. Nessa época eu era observadora das reuniões semanais da equipe multidisciplinar de saúde e dos grupos de apoio psicológico voltados aos pacientes e aos cuidadores familiares. Essa pesquisa teve por objetivo investigar o modo como as mulheres com anorexia nervosa (AN) vivenciam seu corpo, antes e após a instalação do transtorno alimentar, e seus hábitos alimentares. O referido estudo desdobrou-se em algumas publicações (Leonidas \& Santos, 2010, 2011; 2012; 2013; Leonidas, Santos, \& Noce, 2008). Entre os principais resultados obtidos, pode-se destacar que 
a autoestima rebaixada era direcionada para o próprio corpo e, somada a outros fatores de personalidade, acarretava vivências de insatisfação intensa com a forma e o peso corporal, contribuindo para a distorção da imagem corporal. Configuravam-se, assim, as condições psíquicas para a adoção de hábitos alimentares disfuncionais, que colocavam em risco a saúde e o bem-estar geral das participantes.

Em 2010, após a finalização do curso de graduação em Psicologia, permaneci como psicóloga voluntária do GRATA e iniciei minhas atividades como coordenadora do grupo de apoio aos familiares. Dentro de um contexto estimulador da pesquisa, o serviço abriu novamente suas portas, dessa vez para abrigar meu projeto de mestrado (2010-2012). A Dissertação de Mestrado, intitulada Redes sociais e apoio social no contexto dos transtornos alimentares, também financiado pela FAPESP (processo número 2010/01257-7), buscou investigar o modo como se configuram as redes sociais de mulheres com diagnóstico de TAs, assim como o apoio social percebido por elas e suas possíveis implicações para a evolução do quadro psicopatológico. Dentre os principais resultados obtidos assinalamos as valiosas contribuições acerca do impacto da dinâmica das relações familiares sobre o TA, tanto na precipitação e manutenção do quadro clínico, quanto na configuração dessas relações, que se destacaram como a rede de apoio social mais significativa das participantes (Leonidas \& Santos, 2011, 2013, 2014, 2015a, 2015b; Leonidas, Crepaldi, \& Santos, 2013). Nesse cenário, no qual a família configura a principal de rede de apoio social das pacientes, a triangulação entre pai-mãe-filha foi evidenciada em quase todos os casos analisados.

Após a conclusão do mestrado, retomei minha posição de pesquisadora para tentar compreender, de forma mais aprofundada, as relações triangulares entre pai, mãe e filha acometida por TA. A partir da pesquisa de mestrado e de minha atuação como psicóloga do GRATA, pude perceber que essas relações são marcadas por indiferenciação e simbiose entre mãe e filha, assim como pelo distanciamento da figura paterna e conflitos frequentes entre os 
três. Essa percepção me suscitou algumas questões: como a filha pode se desenvolver e criar uma individualidade própria, se se mantém psiquicamente fundida à mãe ao longo da vida, em uma fixação na relação infantil pré-edípica? Seria a anorexia nervosa (AN) uma forma de evitar o aparecimento irrefreável dos atributos femininos, em uma tentativa de manter seu corpo de criança? E na bulimia nervosa $(\mathrm{BN})$, como seria vivenciada a feminilidade? Onde estaria o pai, que permanece excluído da relação fusional mãe-filha e não pode atuar como instância interditora da relação dual e narcísica que regula o funcionamento da dupla? Por fim, questionei-me em relação à vida afetivo-sexual dessas mulheres: se existe uma fusão notória com a mãe e, em decorrência, um impedimento ao despertar da feminilidade da filha, poderia haver espaço emocional disponível para o estabelecimento de uma vida afetiva e sexual satisfatória com um parceiro?

Com o auxílio do referencial teórico da psicossomática psicanalítica e da teoria da sexualidade de McDougall (1991, 1997), este estudo busca investigar possíveis relações entre o desenvolvimento da sexualidade e da feminilidade em mulheres com TAs, a partir das vivências na tríade pai-mãe-filha, e a precipitação e manutenção do quadro, sendo este tomado como expressão sintomática de conflitos de ordem psicossexual inscritos no corpo.

Por fim, é de extrema importância mencionar o período de Doutorado Sanduíche (Processo FAPESP número 2015/15103-5) realizado no Institute of Psychiatry, Psychology and Neurosciences (IoPPN) da King's College London, de Outubro de 2015 a Fevereiro de 2016. Sob a orientação da Profa. Janet Treasure, OBE, PhD, FRCP, FRCPsych, pude conhecer e analisar a fundo as principais intervenções psicológicas desenvolvidas pela equipe do Maudsley Hospital, parte do South London and Maudsley NHS Foundation Trust (SlaM), pioneira na assistência a pacientes acometidos por transtornos alimentares. O hospital oferece várias modalidades de tratamento para esses pacientes, tais como: Serviço de Assistência a 
Crianças e Adolescentes com Transtornos Alimentares, Serviço Daycare, ambulatórios e internações, entre outros.

Para conhecer e analisar as intervenções psicológicas desenvolvidas pela equipe do Maudsley Hospital, liderada pela Profa. Treasure, utilizei a taxonomia de técnicas de mudança de comportamento proposta por Michie et al. (2011), que se mostrou um instrumento bastante útil no reconhecimento dos componentes psicoterapêuticos mais efetivos, assim como dos componentes que poderiam ser aprimorados ou inseridos nas intervenções.

O período de Doutorado Sanduíche no IoPPN possibilitou tanto o aprendizado de como técnicas psicoterapêuticas de tratamento no contexto dos TAs são desenvolvidas e testadas, como também possibilitou que eu entrasse em contato com técnicas inovadoras ainda não utilizadas no Brasil, tais como a utilização de Estimulação Magnética Transcraniana (rTMS) no tratamento da AN. Finalmente, o período de Doutorado Sanduíche também forneceu subsídios para pensar nos próximos passos de minha carreira acadêmica e profissional, que contará com o desenvolvimento do Pós-Doutorado, no qual pretendo traduzir, adaptar e validar uma das intervenções psicoterapêuticas desenvolvidas pela equipe da Profa. Treasure, a saber: MANTRA - The Maudsley Model of Anorexia Nervosa Treatment for Adults. 


\section{INTRODUÇÃO}

Os TAs são quadros psicopatológicos caracterizados por graves perturbações no comportamento alimentar, que afetam, em sua maioria, adolescentes e jovens do sexo feminino (Borges, Sicchieri, Ribeiro, Marchini \& Santos, 2006; Oliveira \& Santos, 2006). Esses quadros podem resultar em prejuízos biológicos, psicológicos e sociais, que acarretam aumento da morbidade e mortalidade (Jones, Evans, Bamford, \& Ford, 2008). A AN e a BN são os dois tipos mais prevalentes de TAs, e serão abordados no presente estudo.

Muitas das pesquisas atuais acerca dos TAs vêm buscando elucidar aspectos etiológicos desses quadros, enfatizando principalmente o papel da cultura na gênese dos mesmos (Gorgati, 2002). A cultura ocidental impõe padrões de beleza e magreza que, quando atingidos, tornam-se símbolos de sucesso. Tais padrões estéticos exercem influência negativa no psiquismo de mulheres jovens e adultas, fazendo-as acreditar que o corpo esbelto seria a solução de seus problemas.

Apesar do papel da cultura ser de extrema importância na etiologia dos TAs, essa perspectiva engloba apenas uma parte do problema. Em se tratando de psicopatologias que transitam entre o somático e psíquico, é necessário um olhar e uma escuta que possam compreender os sintomas para além do somático. Segundo Gorgati (2002), é necessário perceber o sacrifício do corpo que as jovens acometidas realizam, e que as tornam "militantes de uma política pessoal” (p. 116).

\section{Construindo o problema de pesquisa}

Apesar do aspecto manifesto, físico, dos TAs indicarem nítida relação com a estética e a beleza social e culturalmente valorizadas, questões mais profundas podem ser rapidamente percebidas. Os sintomas podem ser considerados o que Gorgati (2002) nomeou de "reforma moral”, que expressam uma subjetividade aflita e solitária, não compartilhável com terceiros. Apesar desses quadros terem início em uma decisão aparentemente simples e superficial - o desejo de perder peso -, tal decisão envolve importante significado inconsciente. 
A literatura científica psicanalítica (Bruno, 2011; Halberstad-Freud, 2001; Miranda, 2011; Ribeiro, 2011) aponta que a dinâmica das famílias que possuem uma filha com TA apresenta padrões de semelhança no que concerne à fusão na relação entre mãe e filha, e o afastamento da figura paterna que, em geral, permanece voltado para o trabalho externo e sustento da casa (Beltrame \& Bottoli, 2010; Elliot, 2010). Nesse sentido, sob a ótica da psicanálise, os TAs colocam em evidência questões relacionadas à: fase pré-edípica, na qual mãe e filha parecem ter se mantido fixadas; individuação da filha, e consequente desenvolvimento da psicossexualidade e acesso à genitalidade - que implica em separação das figuras parentais da infância; questões internas do próprio casal parental, que emergem na literatura como emocionalmente distanciados (Leonidas \& Santos, 2013), abrindo espaço para que a mãe - a quem geralmente é delegada a função de cuidado dos filhos - tome-os como extensão narcísica de si mesma, a fim de suprir possíveis vazios existenciais.

Nota-se, portanto, que aspectos edípicos conflituosos e não elaborados encontram-se no cerne da precipitação dos TAs: as jovens mulheres acometidas por essas quadros não têm espaço interno para desenvolver relações afetivas extrafamiliares e não-incestuosas (Gaspar, 2010; Leonidas \& Santos, 2013), uma vez que permanecem fixadas ao primeiro objeto de amor - a mãe -, e demandando a entrada do pai nessa relação indiscriminada, para que a filha possa localizar seu lugar na família e constituir sua identidade.

A partir desses pressupostos, o presente estudo busca investigar a constituição da sexualidade feminina nos TAs, sob a perspectiva das filhas acometidas, suas mães e seus pais, ou seja, no interior da tríade edípica. A seguir serão delineados os principais tipos de TAs (AN e BN) e, em seguida, tais quadros serão descritos a partir do referencial teórico adotado neste estudo, a Psicossomática Psicanalítica, aprofundando especialmente em questões relacionadas às relações mãe-filha, pai-filha, sexualidade feminina e maternidade. 


\section{Capítulo 1. Delineamento dos transtornos alimentares}

\subsection{Anorexia Nervosa}

De acordo com o DSM-V (American Psychiatric Association, 2013), a AN pode ser caracterizada como uma recusa do indivíduo a manter o peso corporal na faixa normal mínima adequada à sua idade e altura, além de um temor intenso de ganhar peso e uma perturbação significativa na percepção da forma ou tamanho do corpo, resultando em caquexia, ou seja, em uma fraqueza geral do corpo e má disposição corporal decorrente da desnutrição. Existem dois subtipos de AN: o restritivo, no qual a paciente perde muito peso em um curto espaço de tempo, devido a dietas, jejuns ou excesso de exercícios físicos, e o purgativo, que se caracteriza por períodos de restrição alimentar intensa, alternados com períodos de compulsão alimentar seguida de rituais purgativos, tais como vômitos autoinduzidos ou uso abusivo de laxantes, diuréticos e drogas anorexígenas.

Segundo Borges et al. (2006), a desnutrição decorrente da AN costuma resultar em algumas complicações clínicas que podem ser descritas como: pele seca e com aspecto amarelado, cabelos finos, queda de cabelos, unhas quebradiças, problemas nos sistemas cardiovascular (bradicardia, arritimias cardíacas, hipotensão), gastrointestinal (retardo do esvaziamento gástrico, constipação, pancreatite, alteração das enzimas hepáticas), renal (edema, cálculo renal), hematológico (anemia, leucopenia), reprodutivo (amenorréia, infertilidade), metabólico (hipocalemia, hipoglicemia, desidratação) e endocrinológico (hipercolesterolemia, aumento do hormônio de crescimento e cortisol).

No que concerne aos aspectos constitucionais que configuram a personalidade de pacientes com AN, vários autores citam inferioridade, inadequação e insegurança, perfeccionismo, obsessividade, compulsividade, emoções negativas, retraimento e condutas de evitação (Borges et 
al., 2006; Cassin \& Von Ranson, 2005; Leonidas \& Santos, 2012; Nilsson, Sundboom, \& Häglöff, 2008; Peres \& Santos, 2006). Cooper, Deepak, Grocutt e Bailey (2007) sugerem que a experiência de "sentir-se gorda", vivenciada intensamente pelas pacientes com TA, parece estar relacionada a uma combinação de fatores, como angústia, sensações corporais internas e externas, sentimentos de rejeição, exclusão social, além de crenças negativas sobre si mesmas.

Segundo Morgan, Vecchiatti e Negrão (2002), a etiologia dos TAs é multifatorial, ou seja, vários fatores interagem entre si de uma forma complexa e se conjugam na produção dos sintomas, envolvendo: vulnerabilidade genética, traços de personalidade, psicopatologia parental, experiências adversas, pressões socioculturais, entre outros. Oliveira e Santos (2006) propõem a hipótese de uma influência combinada da dinâmica familiar - confusão das fronteiras que definem os subsistemas familiares, que dificultaria a formação da própria identidade e individualidade nos membros da família -, do meio cultural e de aspectos da personalidade do indivíduo como fatores concorrentes na etiologia dos distúrbios relacionados com a distorção da imagem corporal, que predispõem ao desenvolvimento de TAs.

Os referidos autores classificam esses fatores de interação como predisponentes - ou seja, fatores que aumentam a probabilidade de aparecimento dos transtornos alimentares, mas não os tornam inevitáveis; precipitantes - que marcam o aparecimento dos sintomas do transtorno; e mantenedores - que determinam se o transtorno vai se perpetuar ou não. No entanto, a influência desses fatores na vida do indivíduo vai depender da combinação única que eles adquirem em sua individualidade e sua história pessoal.

Os fatores predisponentes podem ser subdivididos em:

- Individuais: traços de personalidade, baixa autoestima, traços obsessivos e perfeccionistas, história de transtornos psiquiátricos, depressão, transtornos de ansiedade, tendência à obesidade, alterações da neurotransmissão nas vias noradrenérgicas e serotonérgicas, eventos adversos e abuso sexual. 
- Familiares: agregação familiar, hereditariedade, padrões de interação familiar, rigidez, intrusividade, evitação de conflitos, desorganização e falta de cuidados.

- Socioculturais: ideal cultural de magreza, hipervalorização do corpo como base para a autoavaliação, influenciando o autoconceito e a autoestima.

Já os fatores precipitantes podem ser caracterizados como rituais de emagrecimento que, no caso da AN, comumente são as dietas e os intensos jejuns. Esses comportamentos são decorrentes de fatores socioculturais comuns às sociedades ocidentais, em que predomina o ideal de magreza, ou de eventos estressores (mudanças de casa ou de escola, divórcio dos pais, puberdade, entre outros). Morgan et al. (2002) pontuam que estudos longitudinais demonstram que a dieta aumenta o risco para o desenvolvimento de transtornos alimentares. Ao aumentar drasticamente a restrição alimentar, o indivíduo fica desnutrido, porém o desejo de emagrecer e o medo de engordar, em contrapartida, tendem a aumentar. No entanto, para que a dieta leve a esse desfecho, deve acontecer simultaneamente com a exposição a outros fatores de risco relacionados à predisposição ao transtorno.

Dentre os fatores mantenedores, podemos mencionar os aspectos:

- Fisiológicos: a privação alimentar favorece episódios de compulsão alimentar e esses episódios interferem no metabolismo da glicose e da insulina.

- Psicológicos: a privação alimentar desencadeia pensamentos obsessivos sobre comida e maior necessidade de controle sobre a alimentação.

- Culturais: a magreza vista como símbolo de sucesso e aceitação social.

De acordo com relatos de pacientes, o início do quadro geralmente está relacionado com a ocorrência de algum fator estressante: comentários críticos sobre o peso, término de relacionamento, perda de um ente querido, entre outros eventos traumáticos. Em seguida, o indivíduo passa a viver em função da dieta, da preocupação com seu peso e sua forma corporal, das atividades físicas, de tabelas de calorias e do medo patológico de engordar 
(Borges et al., 2006). Esse tipo de pensamento obsessivo leva a uma disciplina muito rígida na realização de dietas, cujo êxito acarreta em sentimentos de controle para o indivíduo, fazendo com que este sinta que tem um núcleo de personalidade próprio (Rodríguez, Hernández, \& Bouly, 2000).

O perfil típico dos indivíduos que apresentam quadro de AN é composto pelas características: adolescentes do sexo feminino, raça branca e alto nível socioeconômico e cultural. No entanto, têm-se observado que esse grupo vem se tornando cada vez mais heterogêneo, uma vez que os casos de diagnóstico em adolescentes do sexo masculino, raça negra, pré-adolescentes e pacientes com baixo nível socioeconômico e cultural têm se tornado cada vez mais frequentes (Borges et al., 2006). Além disso, os referidos autores pontuam que a AN costuma ter início entre os 13 e 17 anos de idade, mas casos de início na infância ou após os 40 anos também têm sido observados. Rodríguez et al. (2000) apontam que, dentre os casos de AN, apenas 10\% correspondem à ocorrência em homens.

Quanto à epidemiologia, Smink, Hoeken e Hoek (2013) sugerem que DSM-IV-TM ${ }^{\mathrm{TR}}$ (Associação Americana de Psiquiatria, 2003) apresentava lacunas nos critérios diagnósticos propostos para TAs, fazendo com que a categoria residual “TAs não especificados” (TANE) fosse a mais utilizada em amostras clínicas e populacionais. Portanto, os autores mencionados acreditam que os estudos epidemiológicos publicados até recentemente não apresentavam dados totalmente fidedignos, considerando-se o problema da categoria diagnóstica que era atribuído aos pacientes. Após a publicação do DSM-V (American Psychiatric Association, 2013), Smink, Hoeken e Hoek (2013) realizaram um estudo de revisão sobre a epidemiologia dos TAs, levando-se em conta os novos critérios diagnósticos propostos que, segundo os autores, reduziu efetivamente o uso do diagnóstico TANE. Os resultados indicaram que a prevalência de AN entre mulheres chega a 4\%, e de BN 2\%, e ambas as categorias diagnósticas estavam relacionadas com altas taxas de mortalidade. As taxas de remissão 
apontadas por ensaios clínicos randomizados variaram entre 19 e 65\% entre os estudos incluídos na revisão.

Nota-se que, no geral, existe uma ampla variabilidade entre os dados epidemiológicos apresentados pela literatura específica. Isso se deve a diversas razões, desde questões metodológicas - variações nos métodos de avaliação adotados por cada autor - até socioculturais - hiper ou desvalorização da magreza em diferentes culturas, o que dificulta o estabelecimento de um padrão quantitativo relacionado à epidemiologia do transtorno em questão.

\subsection{Bulimia Nervosa}

Bulimia significa, etimologicamente, “fome de boi”. Ou seja, o termo remete a um apetite ávido, ao qual o indivíduo se entrega com voracidade e edacidade. Esse apetite, no entanto, não diz respeito apenas aos alimentos em si, mas a uma gama de objetos e atividades (Brusset, 2003). Contrapondo-se à preocupação com a economia e o estabelecimento de medida típicas da cultura contemporânea, a bulimia "aparece como o espelho invertido do culto do rendimento” (p. 8) e ilustra os efeitos do consumo exagerado da lógica de mercado.

O exagero típico dos quadros de BN geralmente ocorre em forma de atos privados e solitários, e configura um ataque à cozinha, à educação e aos costumes aprendidos, subvertendo as necessidades biológicas da fome e contestando o que é aceito ética e esteticamente, assim como as normas, os usos, os aprendizados e a dimensão social da refeição (Brusset, 2003). A partir dos ataques desferidos, surgem as reprovações morais e a vergonha vivenciada pelos indivíduos acometidos por esses quadros.

A primeira descrição da BN como entidade nosológica foi proposta por Russell, em 1979. O autor caracterizou esse quadro como uma variante da AN, que apresentava um 
sintoma-chave: o binge eating, ou "farra alimentar". Esse sintoma respondia a três critérios, a saber: (1) os pacientes bulímicos sofriam de intensa e irresistível necessidade de se alimentar de forma excessiva por um determinado período; (2) provocavam vômitos e faziam uso abusivo de laxantes para evitar o ganho de peso; e (3) apresentavam medo mórbido de se tornarem gordos (Rosa \& Santos, 2011; Vindreau, 2003).

Atualmente, segundo o DSM-V (American Psychiatric Association, 2013), constituem critérios diagnósticos para a $\mathrm{BN}$ :

1- Episódios recorrentes de compulsão alimentar periódica, que são caracterizados por:

- ingestão, em período limitado de tempo, de uma quantidade de alimentos definitivamente maior do que a maioria das pessoas consumiria em período e circunstâncias similares;

- sentimento de falta de controle sobre o comportamento alimentar durante o episódio (por exemplo, sentimento de incapacidade de parar de comer ou de estimar quanto está comendo);

2- Comportamento compensatório inadequado e recorrente, com o fim de prevenir o aumento de peso, como autoindução de vômitos, uso indevido de laxantes, diuréticos, enemas ou outros medicamentos, jejuns ou exercícios excessivos;

3- A compulsão periódica e os comportamentos compensatórios inadequados ocorrem, em média, pelo menos duas vezes por semana, há três meses;

4- A autoavaliação é indevidamente influenciada pela forma e pelo peso do corpo;

5- O distúrbio não ocorre exclusivamente durante os episódios de AN.

Há dois subtipos de BN: o purgativo, no qual acontecem os episódios de vômitos autoinduzidos e o uso abusivo de laxantes, diuréticos e enemas, e o não-purgativo, no qual o 
indivíduo realiza intensos jejuns e exercícios físicos excessivos, sem a ocorrência de vômitos e outros comportamentos compensatórios.

O transtorno também está associado a comportamentos impulsivos e comorbidades, tais como traços histriônicos e transtorno de personalidade do tipo borderline (Borges et al., 2006; Kaye, 2008; Paccola, 2006; Vindreau, 2003). Esse transtorno, de forma geral, indica padrões de impulsividade e instabilidade emocional que se refletem nos relacionamentos interpessoais, na autoimagem e nos afetos (DSM-V, Associação Americana de Psiquiatria, 2013). Também se manifestam graves dificuldades para lidar com o abandono - real ou imaginário -, já que a separação ou a percepção de rejeição pode acarretar sentimento de raiva inadequada e ações impulsivas, tais como comportamento suicida ou de automutilação. Além de instabilidade do humor, descontrole emocional e explosões de raiva, os pacientes podem apresentar tristeza, ciúmes intenso, apego afetivo exacerbado, teimosia e insatisfação pessoal (Rosa \& Santos, 2011). Quando esses comportamentos e sentimentos se apresentam de forma recorrente, intensa e persistente, produzem um padrão existencial marcado por dificuldades de adaptação ao ambiente social e suscetibilidade ao transbordamento afetivo. Pacientes borderlines tendem a lidar mal com qualquer tipo de adversidade, especialmente com aquelas que envolvem rejeição, desaprovação ou abandono. Quando se deparam com essas situações, costumam vivenciar uma reação de estresse intensa, com consequências imprevisíveis (Leonidas, Crepaldi, \& Santos, 2013).

Em termos clínicos, as pacientes bulímicas apresentam: pouca perda de peso, peso normal ou até acima do normal; distorção da imagem corporal pouco acentuada; maior incidência por volta dos 20 anos de idade; são mais extrovertidas; referem fome; os comportamentos de compulsão e purgação são motivo de vergonha e culpa, havendo desejo de ocultá-los; são sexualmente ativas; há comorbidades com transtornos afetivos e abuso de álcool e outras drogas (Borges et al., 2006). Além disso, essas mulheres também costumam 
apresentar baixo limiar à frustração, alto nível de ansiedade, autoestima rebaixada e prejuízos no controle dos impulsos (Rosa \& Santos, 2011).

Do ponto de vista do funcionamento psicológico, as pacientes com BN apresentam uma série de pensamentos e emoções desadaptativas a respeito de seus hábitos alimentares e seu peso corporal (Abreu \& Filho, 2004). Além disso, elas também apresentam autoestima flutuante e acreditam que o corpo bem delineado resolveria seus problemas de insegurança pessoal. Para conseguir alcançar esse corpo idealizado, as mulheres com BN realizam dietas excessivas, rituais purgativos e exercícios físicos extenuantes. Assim, atribui-se o desejo que essas mulheres possuem de emagrecer a uma desorganização pessoal, na qual a regulação e o controle da alimentação seriam uma tentativa de obter ordenação e estabilidade do estado psíquico caótico (Abreu \& Filho, 2004).

Em suma, a arquitetura emocional das mulheres com BN inclui: baixa autoestima, pensamento do tipo "tudo ou nada”, ansiedade, perfeccionismo, incapacidade de encontrar formas de prazer e satisfação na vida, busca de problemas mesmo nas coisas corriqueiras, alta exigência, incapacidade de "ser feliz" (Abreu \& Filho, 2004). Segundo Limbert (2010), tais características implicam em uma incapacidade dessas mulheres em desenvolver redes sociais saudáveis, uma vez que elas apresentam dificuldades nos relacionamentos interpessoais e não são socialmente ajustadas.

De acordo com o que é evidenciado pela clínica psicanalítica, a BN é, inicialmente, constituída na economia das experiências de prazer e desprazer que se desenvolvem no cerne das relações afetivas estabelecidas com o próprio corpo e a mãe. Corresponde a uma fixação na etapa oral do desenvolvimento libidinal, à qual o indivíduo regride perante a impossibilidade de acesso ao gozo genital. Brusset (2003) sugere que a BN também surge como um "gozo impossível, um tormento, um sofrimento, uma doença” (p. 8), pois, apesar de ser uma conduta aceita - e até mesmo escolhida e desejada - pelo indivíduo, torna-se fonte de 
angústia e alienação, uma vez que ele se sente tomado por uma necessidade de realizar o ato bulímico, durante o qual se sente fora de si.

No que concerne ao tratamento, Rosa e Santos (2011) sugerem que a psicoterapia auxilia na melhora dos sintomas de quadros de BN, mas é insuficiente como tratamento exclusivo. Até o momento, não há estudos controlados que tratam da eficácia das psicoterapias psicodinâmicas na BN, mas alguns autores apontam que essa modalidade de seguimento contribui para o tratamento das comorbidades, diminuição da ansiedade, melhoria dos relacionamentos interpessoais e elaboração dos traumas por abuso sexual. O guia prático para o tratamento dos transtornos alimentares, formulado pela Associação Americana de Psiquiatria (2006), aponta que a psicoterapia psicodinâmica é aplicável aos pacientes mais comprometidos, com maior incidência de comorbidades. 


\section{Capítulo 2. Marco teórico: Os transtornos alimentares sob a ótica da psicanálise}

Antes do século XVIII, a medicina herdava uma concepção unitária de homem, na qual corpo e mente eram indistintos e formavam uma unidade global. Com a adoção do método cartesiano e o triunfo da concepção positivista, a distância entre mente e corpo foi aprofundada, sendo a histeria a (talvez) única doença cujos sintomas não podiam ser explicados por meio de uma etiologia orgânica (Ávila, 1996). No final do século XIX, Sigmund Freud (1856-1939) provocou uma modificação no paradigma médico vigente na época com a descoberta do inconsciente e a fundação de uma nova teoria sobre os processos psíquicos (Peres, 2006). O médico austríaco, com a colaboração do psiquiatra francês Jean Martin Charcot (1825-1893), desenvolveu uma série de estudos a respeito da histeria e propôs a teoria de que o corpo - e consequentemente as doenças orgânicas - estariam suscetíveis às vicissitudes da mente e não apenas dos agentes biológicos. A partir dessa premissa, passa-se a considerar que “a saúde de um indivíduo se encontra intimamente relacionada à sua própria história” (Peres, 2006, p. 166). Segundo Ávila (1996), os sintomas histéricos vêm recebendo grande atenção da área médica, uma vez que desafiam os avanços da medicina na área de investigação etiológica e farmacológica. Foi com a publicação dos Estudos sobre a histeria (Breuer \& Freud, 1985/1996), que se passou a considerar o aspecto psíquico do corpo doente, ou seja, que a condição da representação corporal passou a ser considerada, e não apenas a anatomia. Freud afirmava que o corpo das histéricas não poderia ser definido apenas pelas paralisias e afasias, já que esses são apenas sintomas por meio dos quais as pacientes demonstravam algo mais complexo de si mesmas (Mezan, 1998), ou seja, seu mundo interno. Nesse sentido, a psicanálise apresentava-se como um modo inédito de investigação e tratamento, pois colocava a “possibilidade de representar a mediação da mente na produção do sintoma” (Ávila, 1996, p. 67).

A partir desses pressupostos, as doenças podem ser compreendidas para além do viés orgânico, como respostas fisiológicas - também nomeadas como respostas somáticas - a 
estados de tensão emocional gerados por processos mentais que não foram simbolizados (Peres, 2006). A ocorrência de processos libidinais arcaicos e a ausência do estabelecimento de conexões com conteúdos simbólicos parecem resultar na utilização de caminhos mais rápidos e diretos de escoamento das tensões. Ou seja, o inconsciente, impedido de se comunicar a partir do emprego de representações mentais, tende a utilizar o corpo como via única de expressão. A assunção psicanalítica, portanto, é de que os sintomas apresentam um sentido para cada indivíduo, que tem conexão com a sua história (Ávila, 1996).

Joyce McDougall (1991) sugere que pacientes somáticos apresentam pouca capacidade de elaborar afetos potencialmente desestruturantes, e por esse motivo acabam fazendo uso de mecanismos defensivos arcaicos para evitar desestabilizações emocionais que fujam de seu controle. Pode-se dizer que esses indivíduos “ejetam” os afetos do próprio aparelho mental, reduzindo-os a sua pura expressão somática. De forma geral, as somatizações são "processos causados por lacunas no aparelho mental que favorecem a tradução corporal de uma história sem palavras” (Peres, 2006, p. 173).

Segundo Bruno (2011), Freud pensava o fenômeno da histeria a partir da existência de conflitos inconscientes entre o desejo (sexual) e sua proibição. Tais conflitos seriam direcionados para o corpo e simbolicamente seriam representados por quadros clínicos como parestesia (paralisia de membros), cegueira temporária e falta de apetite (anorexia). Daí a comparação da psicanálise clássica entre a AN e a histeria. Já no caso das compulsões, o corpo seria usado como "objeto de descarga do desejo sexual, mas é proibido sentir o afeto" (Bruno, 2011). Dessa forma, o afeto não seria sofrido e nem experimentado: o corpo seria vivido em seu aspecto meramente físico, como objeto de descarga.

Nota-se, então, que os recursos psíquicos de indivíduos acometidos por TAs para lidar com a realidade tendem a ser escassos e pouco elaborados (Bruno, 2011). Há uma impossibilidade de se utilizarem áreas mais desenvolvidas da mente e a organização mental 
acontece a partir de princípios rígidos, leis e regras definitivas, que garantem a impermeabilidade do ego às mudanças. Miranda (2011) argumenta que os TAs se configuram a partir do momento em que o "o nada comer", ou o "comer o nada”, e o "tudo devorar" passam a ocupar um espaço primordial no psiquismo do indivíduo, “impedindo o desenvolvimento de suas potencialidades criativas” (p. 123). Não há espaço disponível para a vida de fantasia, para o prazer e, consequentemente, abre-se caminho para os pensamentos estereotipados e automatizados (Bruno, 2011). Não se pode ter medo nem sofrer dor e amor.

Para a psicanálise, os TAs podem ser considerados como manifestações sintomáticas orais de um conflito psíquico originado a partir de angústias vivenciadas em épocas primitivas da vida mental (Miranda, 2011). Os afetos não são vividos e a mente passa a ser alojada no corpo, que traduz algo da história do sujeito e das lacunas produzidas em seu aparelho mental. Segundo a autora, “as anoréxicas/bulímicas burlam a possibilidade de pensar a dor” (p. 124).

O direcionamento dos conflitos inconscientes para o corpo configura, de modo geral, uma forma de expressão desprovida de valor simbólico (Peres, 2006). Segundo McDougall (1989), perturbações na relação mãe-bebê são fatores etiológicos centrais nessa dificuldade de simbolização, que a autora denomina de desafetação - neologismo criado para fazer referência a distúrbios da economia afetiva, nos quais os afetos e suas representações são expulsos do aparelho psíquico.

O neologismo “desafetação”, criado por McDougall (1989), foi desenvolvido a partir da ideia de que uma pessoa se “desafeiçoa” de alguém ou de alguma coisa quando lhe retira sua afeição, ou seja, quando dela se desapega.

O prefixo latino “des” (que contém a ideia de separação ou de perda) pode sugerir metaforicamente que determinado indivíduo está psiquicamente "separado" de suas emoções e pode ter "perdido" a capacidade de ficar em contato com suas realidades psíquicas. (McDougall, 1991, p. 104) 
No contexto analítico, a autora se refere à palavra desafetada, ou seja, a palavra que se encontra separada de sua função de ligação pulsional, emergindo apenas como "estruturas congeladas, esvaziadas de substância e de significação” (McDougall, 1991, p. 104). Trata-se de um discurso sem afeto. Ao se referir à desafetação, a autora faz uma alusão à vivência dentro de uma prisão, sugerindo que "nela o indivíduo está protegido e pode sobreviver” (p. 105). São indivíduos que viveram emoções intensas em épocas muito precoces da vida, que ameaçavam seu sentimento de integridade e identidade. Assim, para sobreviverem psiquicamente, foi-lhes necessário desenvolver um sistema que evitasse a retomada de situações traumáticas, que comportavam uma ameaça de aniquilamento. Para tanto, qualquer representação carregada de afetos era simplesmente ejetada da consciência, evitando-se estabelecer contato com a mesma.

Eles não sofriam de uma incapacidade de vivenciar ou de exprimir uma emoção, mas sim de uma incapacidade de conter o excesso da experiência afetiva (próxima à angústia psicótica) e, portanto, nessas condições, de uma incapacidade de refletir sobre essa experiência. (McDougall, 1991, p. 105)

A figura materna desempenha a função primordial de proteger o bebê das tensões provenientes do ambiente (Peres, 2006). Para isso, é necessário que ela possa interpretar os sinais comunicativos do filho e nomear seus estados afetivos, de modo a favorecer a “dessomatização do aparelho mental” (p. 172). Quando essa tarefa é desempenhada de forma adequada, o bebê passa a desenvolver a capacidade de acesso à palavra e à simbolização. Em contrapartida, quando a figura materna não desempenha sua função de para-excitação, os sinais pré-verbais do bebê não são inseridos na linguagem e suas experiências não podem ser simbolizadas. Assim, os conflitos passam a ser exteriorizados no corpo, gerando as somatizações. 
A nomeação dos TAs como "patologias do vazio" nos remete à retirada afetiva, ao “preenchimento em branco”, ou seja, dizem respeito às “técnicas de evasão utilizadas pela mente como meio de sobrevivência em ambiente hostil” (Bruno, 2011, p. 97). Mas a que ambiente hostil estamos nos referindo? Tentaremos demarcar essa questão no próximo tópico.

\subsection{A relação mãe-filha nos transtornos alimentares}

Durante a adolescência, a jovem experimenta o reativamento do embate entre diferenciação e indiferenciação do binômio sujeito-objeto (Gorgati, 2002), ou seja, entre mãe e filha. Essa questão será mulher discutida posteriormente. No entanto, o objetivo deste tópico é pontuar que, na adolescência, a triangulação com as figuras parentais ganha novos enredos, conflitos edípicos são reavivados e, nos casos de TAs, a relação mãe e filha ganha destaque.

Há muito tempo, afinal de contas, já abandonamos qualquer expectativa quanto a um paralelismo nítido entre o desenvolvimento sexual masculino e feminino. Nossa compreensão interna dessa fase primitiva, pré-edipiana, nas meninas, nos chega como uma surpresa, tal como a descoberta, em outro campo, da civilização da Grécia. Tudo na esfera dessa primeira ligação com a mãe me parecia tão difícil de apreender nas análises - tão esmaecido pelo tempo e tão obscuro e quase impossível de revivificar - que era como se houvesse sucumbido a uma repressão especialmente inexorável. (Freud, 1972/1931, p. 234)

A vasta literatura disponível acerca da relação entre mãe e filha acometida por TA é convergente ao propor a hipótese de uma fusão da dupla, que envolveria a vivência de emoções ambivalentes e antagônicas. Mãe e filha se tornam dependentes uma da outra e, em contrapartida, sentem medo e horror em relação a tal dependência, que implica em uma busca infinita pela completude de um vazio que parece nunca ser preenchido (Miranda, 2011).

Segundo Lawrence (1991), as mães de mulheres com AN costumam ser excessivamente cuidadosas e ansiosas em relação ao bem-estar de suas filhas, inclusive no 
que diz respeito à alimentação. A autora descreve mães que se adiantavam às necessidades das filhas e satisfaziam o que acreditavam que as filhas queriam, sem que estas precisassem pedir. Mencionando Winnicott, Lawrence (1991) sugere que, nos primeiros estágios de vida, mãe e bebê têm um relacionamento íntimo e simbiótico, no qual o bebê sente a mãe como uma extensão de si mesmo. Para que este possa começar a se perceber como indivíduo, isto é, ser único e separado, é necessário que a mãe possa se afastar e sair do estado de fusão ilusória com o bebê, deixando que ele expresse seus desejos e angústias: "Se nunca lhe permitem expressar o que quer, ele [o bebê] poderá crescer muito bem nutrido, porém jamais aprenderá que tem uma voz e que esta é a voz a que as pessoas vão responder” (Lawrence, 1991, p. 68). Portanto, essa experiência é crucial para que a criança desenvolva a compreensão de si mesmo, o sentido de self, seus esquemas de autonomia e a habilidade de agir no mundo.

No entanto, a separação da menina em relação à mãe é problemática durante todo o seu desenvolvimento, pois todo passo em direção à independência é acompanhado por conflitos inconscientes vivenciados por ambas as partes da dupla, resultando em tendências regressivas à fase pré-genital (Halberstad-Freud, 2001). A necessidade de independência da filha desperta sentimentos de culpa e medo da perda do amor da mãe, principalmente quando a mãe se mostra incapaz de lidar com tal independência. Para a menina, a separação - que está relacionada com a busca pela autonomia - quase sempre implica em sensação de deslealdade e agressão contra a mãe, ainda que não haja ataques em atos ou em pensamentos. A mãe pode vivenciar a separação como uma traição, despertando sentimentos de culpa na filha, que passa a sentir a separação de forma paradoxal: por um lado, busca a autonomia para que possa traçar seu próprio percurso rumo à conquista da autoestima, feminilidade e sexualidade; por outro lado, sente-se culpada por desejar a autonomia, que é sinônimo de sofrimento para a mãe (Halberstadt-Freud, 2001). 
Campos et al. (2012), ao estudar as características de mães de filhas com TAs, identificaram importantes traços comuns da relação mãe-filha nos casos de AN: por um lado, havia devoção e paixão de ambas as partes; por outro, aniquilamento em decorrência da intensa fusão, que impede o desenvolvimento da individualidade. Essas relações eram marcadas por controle mútuo intensa dicotomia, ou seja, ao mesmo tempo em que mãe e filha se sentiam onipotentes na vida uma da outra, também sentiam-se impotentes; ao mesmo tempo que amavam, se aniquilavam.

De maneira condizente com o que foi proposto por Campos et al. (2012), a problemática da relação entre mãe e filha foi bem definida pelo conceito de “ilusão simbiótica”, criado por Halberstadt-Freud (2001). Tal conceito aprofunda a ideia de “simbiose”, desenvolvida por Margareth Mahler, ao fazer referência às relações patológicas entre mães e filhas, que ocorrem quando a mãe espera satisfazer todas as suas necessidades e desejos tendo um bebê. Quando o bebê é do sexo feminino, parece ser mais fácil para que a mãe se identifique com este e crie um laço inconsciente mútuo, ilusório e parasitário com a filha (Halberstadt-Freud, 2001). Esta última, por sua vez, sente que sua individuação e consequente separação da mãe poderão trair a necessidade que ambas têm da unidade formada na fase pré-edípica. Há um self precário, de ambas as partes, que necessita da manutenção desta unidade para sobreviver.

A ilusão simbiótica parece ocorrer principalmente em mães que vivenciam dolorosos sentimentos de incompetência pessoal, resultantes de conflitos não elaborados com suas próprias mães. Segundo Halberstadt-Freud (2001), a mãe experimenta sentimentos ambivalentes: por um lado, deseja partilhar da onipotência do bebê, que ela percebe como “todo poderoso”; por outro lado, enxerga a criança como impotente extensão narcísica de si mesma, e sente-se onipotente ao perceber o quanto é necessária para aquele bebê. Trata-se de 
mães que precisam de confirmações de sua boa maternagem. Sentindo-se poderosa, a mãe defende-se da dependência que tem de seu bebê e de sua própria mãe.

Ainda de acordo com os pressupostos de Halberstadt-Freud (2001), considera-se que os sentimentos negativos vivenciados pela mãe durante o início da maternagem podem fazer com que esta use a filha como forma de tamponar angústias e de realizar seus próprios desejos. A mãe comporta-se como indispensável - mesmo já não o sendo - e impede a separação, uma vez que, ao separar-se, deixaria de ser a primeira na mente da filha. A separação seria vivenciada pela mãe como abandono e golpe narcísico da filha, além de símbolo de sua falha em exercer a boa maternagem. Nota-se, portanto, que a ilusão simbiótica implica em uma desistência de seu próprio self - tanto da mãe quanto da filha - em vista de receber amor e satisfação de desejos. Tal desistência, além de abrir possibilidades para a precipitação de transtornos (tais como: fobias, paranoia e hipocondria), também afeta o desenvolvimento sexual da filha, que poderá se sentir alienada de seu próprio corpo, o que ainda será percebido como propriedade materna (Halberstadt-Freud, 2001).

Uma das formas encontradas para manter a ilusão simbiótica é manter sentimentos proibidos no plano inconsciente. Tais sentimentos envolvem: ódio, inveja, desejo de agressão, e até mesmo opiniões diferentes. Todos esses sentimentos, que podem ser vividos por ambas as partes da dupla mãe-filha, representam ameaça de quebra da ilusão e, portanto, daquilo que mantém certo nível de integração do self. Assim, é realizado um pacto inconsciente de sacrifício da própria independência em troca do cuidado e do amor. A dependência garante o amor, e resulta em uma intimidade fingida ou simulada que suprime sentimentos de culpa. “Qualquer ódio inconsciente é silenciado” (Halberstadt-Freud, 2001, p. 159). Nesse sentido, hipotetiza-se que se torna impossível que a filha desenvolva relações com verdadeira intimidade, uma vez que a vivência da intimidade implica na ameaça de diluir-se no outro. 
No caso específico dos TAs, a ilusão simbiótica entre mãe e filha é muito nítida. Miranda (2011) propõe a ocorrência de falhas na internalização do triângulo edípico pela menina: a filha passa a se identificar com as partes faltantes da mãe e desenvolve um vazio ao qual tenta preencher a todo custo, buscando a impossível completude. Por outro lado, trata-se de uma mãe intrusiva e destrutiva, que dificulta o pensamento, o uso de palavras e a simbolização em si (Lawrence, 1991). Dentro desse contexto, considera-se que o TA configura uma forma radical e inconsciente da menina se separar da mãe, de modo a escapar da intrusividade materna e alcançar sua individuação, fazendo nascer o seu próprio desejo.

Em consonância com as ideias trazidas por Halberstadt-Freud (2001) a respeito das dificuldades da mãe em se separar da filha, Miranda (2011) sugere que ela própria tenha vivenciado conflitos relativos à fase edípica, na qual possivelmente não houve a entrada do pai no mundo simbólico da filha (Miranda, 2007). A mãe toma o bebê como parte de si e deseja jamais abandonar a unidade fusional formada, enquanto que a criança, percebendo o vazio na mãe, identifica-se como objeto que pode suprir sua falta: “uma não pode deixar de nutrir a outra” (p. 31). No entanto, essa mãe, com sua "fome ilimitada de completude para seu vazio” (p. 30), adentra o espaço psíquico do bebê de forma intrusiva e devastadora. Nesse sentido, a mencionada autora propõe que o emagrecimento na AN expressa no corpo o desejo de separação da mãe, com a retirada dos conteúdos maternos colocados intrusivamente no psiquismo da menina. Já o comer compulsivo, por sua vez, caracterizaria a tomada do alimento como um fetiche que, de forma fantasiosa, fortalece o ego fragilizado e fragmentado da menina, atenuando ou aplacando suas angústias. Trata-se de uma reatualização da relação primitiva com a mãe-seio: o alimento supre o vazio e afasta as possíveis ameaças do ambiente, ilusoriamente curando e tranquilizando (Miranda, 2007).

A fusão e a decorrente angústia de separação em relação à mãe também estão relacionadas com as representações inconscientes da feminilidade: a irrupção da sexualidade 
na adolescência leva a menina a vivenciar um luto pelo seu corpo infantil que, assim como sua mãe, está sendo deixado para trás. Dessa forma, Miranda (2007) considera que a recusa alimentar pode configurar uma tentativa de conter a angústia de separação, ou seja, mantendo seu corpo de criança, a menina também mantém a relação primitiva e fusionada com sua mãe. Da mesma forma, o comer compulsivo também pode caracterizar uma forma de incorporar o objeto bom - o seio e, consequentemente, a mãe -, mantendo-a sempre por perto, juntamente com o afeto perdido.

\subsection{A função paterna na família e na constituição da identidade dos filhos}

Desde sempre, o ser humano necessita dos pares para se manter vivo, aquecido, alimentado, e a família configura o primeiro grupo que fornece ao homem os cuidados necessário para sua sobrevivência. A família, enquanto fruto da criação social, se modifica ao longo do tempo de acordo com as reorganizações político-econômicas e sociais da cultura na qual está inserida (Durham,1983). Conforme a humanidade sofre transformações sociais, a família também sofre (Mandelbaum, 2012). Uma das formas de se observar as mudanças ocorridas no cenário familiar é por meio dos atributos considerados inerentes à função paterna (Costa, 2014).

Até meados dos anos 50, o pai era considerado "chefe de família”, indicando sua posição enquanto principal provedor financeiro e, portanto, autoridade máxima dentro do lar. Ao cumprir sua função de provedor e trabalhador externo, o pai mantinha-se afetivamente distante da esposa e dos filhos, o que favoreceu a legitimação da figura materna como principal responsável pelo cuidado dos filhos e dos afazeres da casa (Gomes \& Resende, 2004). No entanto, as reorganizações dos papéis sociais masculinos e femininos na contemporaneidade têm implicado também em reconfigurações familiares: em função das 
novas demandas atuais, a mulher passa a se inserir no mercado de trabalho e o pai, por sua vez, passa a se aproximar do desenvolvimento dos filhos e a participar mais efetivamente da educação, do cuidado com a saúde, do desempenho escolar, da construção da identidade de gênero, entre outros (Beltrame \& Bottoli, 2010). Pode-se dizer que, na atualidade, houve tantas redefinições nas identidades individuais, conjugais e parentais, que as questões de gênero, casamento, família, maternidade e paternidade escapam aos padrões antigamente vigentes e tradicionalmente instituídos, o que leva à necessidade do desenvolvimento de experiências cada vez mais múltiplas, criadas dentro de cada grupo familiar de acordo com suas próprias particularidades e modos de funcionamento (Beltrame \& Bottoli, 2010).

Segundo Vieira e Nascimento (2014), as diferentes “paternidades” que foram surgindo ao longo dos anos podem ser divididas em três grupos, a saber: paternidade patriarcal, paternidade moderna e paternidade andrógena. A paternidade patriarcal, prevalente de 1620 a 1800, envolvia um distanciamento emocional entre pai e filho, uma vez que o pai era a autoridade máxima da família. A paternidade moderna, instituída por volta de 1800, incluía a ausência física do pai, pois este trabalhava fora e continuava exercendo o papel exclusivo de provedor. Por fim, a paternidade andrógena, que surgiu na década de 70 e permanece vigente em muitas famílias até os dias atuais, envolve maior participação paterna nos afazeres domésticos e no cuidado dos filhos (Costa, 2014).

Para a psicanálise, o pai tem a função primordial de interditor da relação mãe-filho, principalmente no período das vivências edípicas (Bouchereau \& Corcos, 2008; Gomes \& Resende, 2004). Tanto para Freud quanto Winnicott, tais vivências ocorrem por volta dos três anos de idade, e envolvem a capacidade da criança de investir libidinalmente em outro (Zimerman, 1999). A interdição paterna deve ocorrer sobre os desejos da criança em relação à mãe, e regular a capacidade da criança em investir em objetos reais. Porém, além da importância de interditar os desejos da criança, o pai também exerce função crucial na 
adolescência, momento em que o jovem se depara com a necessidade de definir sua identidade sexual (Costa, 2014).

De acordo com Winnicott (1945/2000), o bebê vivencia um estado de não integração nos estágios iniciais da vida, quando ainda não consegue diferenciar o "eu” do "não eu”. Nesse estágio, a mãe ainda não é percebida pelo bebê como algo separado e diferente de si, pelo contrário: o seio - e consequentemente a mãe - são tomados como parte de um mesmo todo. Ainda não existe um “eu” e, consequentemente, um “outro”. A individuação e o desenvolvimento do self tendem a ocorrer durante o desenvolvimento da criança, sendo que este desenvolvimento envolve várias etapas, e em cada etapa o pai desempenha uma função diferente: ele não é apenas o interditor da relação mãe-filho, mas seu papel se altera a cada etapa do amadurecimento da criança (Fulgêncio, 2007). A presença ou ausência do pai, a existência ou não de vínculo entre pai e filho, a sanidade ou insanidade paterna, sua personalidade livre ou rígida, são características que repercutem de várias maneiras sobre o desenvolvimento da criança (Winnicott, 1969/1994). Costa (2014) propõe que o falecimento do pai, até mesmo antes do nascimento da criança, tem uma função sobre o desenvolvimento desta, uma vez que o pai já está presente na realidade interna da mãe, que é transmitida ao filho.

No que diz respeito à relação entre pai e filha com TA, alguns autores propõem a existência de um vínculo inseguro, marcado pelo distanciamento afetivo e por dificuldades de diálogo (Back, 2011; Costa, 2014; Elliott, 2010; Hooper \& Dallos, 2012; Lam \& McHale, 2012; Nodin \& Leal, 2005). Tal insegurança no vínculo parece estar relacionada ao medo das filhas de serem abandonadas e rejeitadas pelos pais (Jones, 2005/2006). Segundo Elliott (2010), as filhas com TAs percebem os pais como fisicamente ausentes e emocionalmente indisponíveis, o que parece gerar um distanciamento entre os membros da dupla. Já para Nodin e Leal (2005), há uma precária elaboração inconsciente da relação com o pai, originada 
em momentos muito primitivos da vida psíquica das filhas, quando o pai não teria assumido a função de interditor da relação mãe-filha e dificultando, portanto, o desenvolvimento psicossexual desta última.

A idealização emergiu em alguns estudos (Elliott, 2010; Hooper \& Dallos, 2012; Nodin \& Leal, 2005) como o mecanismo de defesa mais utilizado, tanto pelos pais quanto pelas filhas, para lidarem com as dificuldades da infância e da vida em família. Hooper e Dallos (2012) sugerem que pais de filhas com TAs vivenciaram experiências de intenso sofrimento em sua própria infância, mas relatavam tais experiências de forma emocionalmente distanciada e, defensivamente, apresentavam visão idealizada desta época da vida. Nodin e Leal (2005) e Elliott (2010), por sua vez, propõem que a visão idealizada que as filhas apresentam da figura paterna também remete a um mecanismo de defesa, utilizado para negar o distanciamento afetivo e o medo do abandono.

Por fim, vale ressaltar que, segundo Winnicott, o pai maduro interdita as fantasias desconectadas da realidade, ao mesmo tempo em que favorece a criatividade do filho. "O pai, homem real, ao mesmo tempo em que aceita a rivalidade, não desautorizando, nem desmerecendo a fantasia, faz a sua parte e realiza o ato objetivo de intervir na consecução dos desejos da criança, impedindo, por exemplo, que esta, sistematicamente, durma com a mãe na cama do casal. Mas, ao mesmo tempo em que intervém, podendo até zangar-se, ele continua cuidando da criança, como sempre o fez, a partir da real maturidade dela. Depois da intervenção, aceita o eventual convite para andar de bicicletas ou, antes de dormir, lê para ele o livro de histórias, retomando com o filho a vida comum” (Fulgêncio, 2007, p. 118). 


\section{Capítulo 3. Sexualidade e psicanálise}

Na sociedade ocidental contemporânea, as expressões da sexualidade e a intensidade das experiências afetivo-sexuais são valorizadas como dimensões centrais na vida dos adolescentes e jovens adultos. É na adolescência que, geralmente, ocorre o início da vida sexual, em paralelo com as transformações do corpo ocorridas ao longo do tempo, a partir da puberdade. Não é por acaso que também é nessa etapa que eclodem os TAs, colocando em evidência as intensas distorções que incidem na imagem corporal, interligadas com sintomas que reverberam nas emoções, sentimentos e sensações de prazer e desprazer.

No presente estudo adotamos uma concepção de sexualidade que remete aos significados que cada sujeito atribui às suas vivências afetivo-sexuais, nas quais o seu corpo é atravessado por todas as experiências vividas na relação consigo mesmo e com o outro, e que traz, portanto, as marcas do afeto e do desejo. No conceito psicanalítico de sexualidade estão incluídas as dimensões não apenas das pulsões, mas também da aprendizagem (sobretudo nos anos iniciais da infância, a partir das interações estabelecidas com as figuras parentais) e as potencialidades do sujeito de se apropriar de suas vivências. Isso significa que é por meio desse conceito ampliado de sexualidade que podemos compreender o modo como cada sujeito organiza e sente aquilo que vivencia, atribuindo sentido a cada experiência vivida. Ao considerar essas premissas, é possível argumentar que a abordagem psicanalítica da sexualidade vai muito além da genitalidade, da anatomia e do funcionamento do corpo, pois os órgãos sexuais não existiriam fora de um psiquismo que os organiza.

[...] O “corpo que a psicanálise descreve quando estuda os sintomas "funcionais" ou conversivos é um corpo trabalhado, cujas manifestações não podem ser reduzidas às ações físicas e químicas do ambiente ou do organismo, mas que deve ser entendido com um corpo pulsional. Transtornos aparentemente somáticos só podem ser compreendidos em sua relação com um corpo que é erogeneizado [...]. A sexualidade é a produtora dos avatares do corpo, e a 
psicossexualidade se revela como a verdadeira história que subjaz ao indivíduo, seja em sua mente, seja em seu corpo. (Ávila, 1996, p. 76) ${ }^{1}$.

Com a globalização, constata-se que aquilo que parecia mais sólido, resistente à mudança, nossos corpos, nossas preferências sexuais, nossas identidades, nossa própria natureza enquanto seres sexuados, estão sendo ressignificados de formas muitas vezes radicais e transformadoras. Atualmente, a sociedade vive uma revolução inacabada, mas profunda, que tem transformado a vida sexual e íntima. Mudanças dramáticas na vida familiar e conjugal vêm ganhando ritmo desde os anos 1990, que incluem modificações no comportamento erótico, nas identidades sexuais, na parentalidade, relações entre homens e mulheres, homens e homens, mulheres e mulheres, adultos e jovens e em leis, normas e valores (Weeks, 2009).

Para Weeks (2009), o termo "liberação" sexual não é adequado para se referir aos progressos realizados nos âmbitos do prazer, do desejo, da diversidade e da escolha sexual. Citando Foucault (1979), Weeks (2009) pontua que “não se pode ‘liberar’ a sexualidade como se estivesse removendo a tampa de um caldeirão" (p. 16), uma vez que a sexualidade não é uma propriedade e não pode ser reprimida ou liberada. Pelo contrário, a sexualidade envolve uma série historicamente construída de possibilidades, ações, comportamentos, desejos, riscos, identidades, normas e valores que podem ser reconfigurados e recombinados, mas não simplesmente liberados. As mudanças que têm ocorrido na cultura englobam todos os aspectos envolvidos na sexualidade, desde práticas eróticas até a reorganização do espaço sexualizado, e desde interações cotidianas até religião, ética e lei (Weeks, 2009).

Segundo Birksted-Breen (2005), as formulações teóricas de Freud acerca da sexualidade feminina foram alvo de críticas desde a escrita de Algumas Consequências Psíquicas da Distinção Anatômica entre os Sexos (1925). Freud priorizava a inveja do pênis

\footnotetext{
${ }^{1}$ Grifos do autor.
} 
como central na iniciação para a feminilidade, mas a questão da determinação biológica versus outros aspectos constitucionais e culturais no desenvolvimento do feminino vem gerando grandes debates entre algumas perspectivas psicanalíticas desde aquela época. Enquanto Freud enfatizou a relativa independência do desenvolvimento de masculinidade e feminilidade em relação ao sexo biológico, Melanie Klein, em contrapartida, via a masculinidade e feminilidade naturais como negociadas através de impedimentos defensivos contra sua expressão. Para Klein, a menina tem sempre um conhecimento, ainda que inconsciente, da vagina, e anseios heterossexuais naturais desde o início da vida. (BirkstedBreen, 2005). Já na França, Lacan e outros psicanalistas seguem o caminho de Freud ao questionar a existência de uma pulsão heterossexual natural: tais teóricos não consideram que exista um sujeito masculino ou feminino dado previamente, e sim um sujeito humano que se desenvolve dentro dos termos da linguagem, ou seja, a partir de uma lógica que vem de fora do indivíduo (Birksted-Breen, 2005).

Kehl (2008) propõe que os seres humanos são precedidos por formações da linguagem que os inscrevem em determinadas posições na ordem simbólica: os significantes "homem” e “mulher” são os primeiros que nos designam antes mesmo do nascimento, antes que a criança se constitua em sujeito do desejo e tenha possibilidades de escolha. A biologia e a cultura nos designam "homens" ou "mulheres” e nossos pais assim nos acolhem a partir da diferença inscrita em nossos corpos, com a qual teremos de nos haver para enunciarmos nossa presença no mundo. A mencionada autora sugere que a posição que cada sujeito ocupa na ordem familiar, a representação que cada um tem no inconsciente dos pais e o que cada um herda das gerações passadas marca o desejo do sujeito, que o diferencia dos outros. 


\subsection{O devir da feminilidade: a sexualidade feminina à luz da psicanálise}

Quando encontram um ser humano, a primeira distinção que fazem é 'homem ou mulher?' e os senhores estão habituados a fazer essa distinção com certeza total. A ciência anatômica compartilha dessa certeza dos senhores num ponto, não mais que isto. (Freud, 1976/1933, p. 114)

A psicanálise se constitui como primeiro discurso fundado em uma interrogação sobre o feminino, centralizando a questão da diferença sexual (Neri, 2005). Neste estudo serão utilizadas, como referencial teórico, as propostas do Psicossoma em Psicanálise, associado com a Exploração Psicanalítica da Sexualidade Humana, ambas desenvolvidas por Joyce McDougall nos livros Teatros do Corpo (1991) e As Múltiplas Faces de Eros (1997). Essas propostas trazem a concepção de que as manifestações psicossomáticas, além de serem consideradas reações corporais ao sofrimento psicológico, indicam intensas vivências da impossibilidade da individualização da filha e de separação do corpo da mãe. Uma vez fundida à mãe, a filha passa a ter um “corpo combinado” (McDougall, 1991), ou seja, um corpo que traz elementos seus e também da mãe. O psiquismo tenta “fazer falar” por meio das inscrições físicas das somatizações. A seguir, serão descritos os construtos da psicossomática psicanalítica e da sexualidade feminina, de forma a demonstrar como ambos estão intimamente articulados na produção dos sintomas que são classicamente observados nas psicoses, nas perturbações mentais em geral e nos TAs em específico, que configuram nosso objeto de estudo.

Vale ressaltar que, segundo Holovko (2008), o conceito de feminilidade aborda a compreensão das mulheres a partir de seus próprios padrões, incluindo a presença de uma sexualidade com características próprias, femininas. Nesse sentido, o presente estudo traz a questão da feminilidade e da sexualidade feminina não apenas destacando aspectos da vida sexual das mulheres e do uso dos órgãos sexuais de prazer e reprodução, mas também das 
experiências corporais e emocionais especificamente femininas, com suas características marcantes (como a menstruação, sensualidade, maternidade, entre outras), que exercem papel crucial na construção da feminilidade. Consideram-se também as experiências edípicas e sua relação fundamental com os destinos da sexualidade feminina.

Reconhece-se que Freud fez descobertas consideradas revolucionárias acerca da sexualidade humana e de sua importância na vida psíquica da criança e do adulto. Entretanto, há várias críticas atuais a respeito de suas limitações conceituais, principalmente no que concerne às suas teorias sobre a sexualidade feminina. McDougall (1997) refere que, apesar de Freud ter sido revolucionário no sentido de ouvir as mulheres e considerar o que diziam como tendo significado e relevância clínica, uma vez que a época em que vivia era predominantemente falocrática, ele também temia os objetos de sua fascinação, ou seja, a feminilidade e o sexo feminino. Em seu texto "Feminilidade", Freud (1976/1933) caracterizava a natureza da sexualidade feminina como um enigma, tendo esse termo sido empregado em função da tortuosidade do caminho percorrido para a compreensão da feminilidade, campo teórico que mantém, até os dias atuais, várias questões em aberto. Quando falava sobre a sexualidade feminina, Freud se referia ao genital feminino como um "vazio ameaçador, uma falta, um continente obscuro e inquietante no qual não era possível ver o que ocorria” (McDougall, 1997, p. 4). Além disso, o fato de tomar a sexualidade masculina como ponto de partida resultava na ideia de que a menina apresentava uma inveja extrema do órgão visível do menino e deseja possuir, ela própria, um pênis.

Entretanto, segundo McDougall (1997), a maioria dos analistas contemporâneos concorda que a inveja do pênis do pai, assim como a configuração anatômica da menina pequena, representa um aspecto apenas parcial do percurso percorrido por ela durante o desenvolvimento da feminilidade. Melanie Klein (1945) propunha que, pelo fato de a menina ter dificuldade em enxergar seu órgão genital, e embora possa perceber as sensações clitoridianas e vaginais, ela 
vivencia seu órgão como faltante, diferentemente do órgão visível de seu pai. Essa vivência pode dar origem a experiências corporais bastante negativas para a mulher adulta, que pode perceber seu corpo como "um continente obscuro no qual monstros anais e orais espreitam” (McDougall, 1997, p. 7). Para Lacan (1958), o falo - cuja noção remete à representação do pênis ereto nos rituais gregos - alude à representação da completude narcísica e do desejo sexual, ou seja, pode ser considerado como significante primordial da falta e do desejo humano, tanto para a mulher quanto para o homem. No caso da mulher, esta pode vivenciar a ausência do pênis como uma falta narcísica, que se articula no complexo de castração, de modo que o “falta-a-ter” torna-se “falta-a-ser” (Lacan, 1958). Os órgãos genitais femininos, abertos à invasão, são representantes da vulnerabilidade, portanto o desejo de ter o falo remete à busca pela completude, por acreditar que o fato de possuí-lo manterá afastados os sentimentos de falta, vulnerabilidade e de não estar à altura (Birksted-Breen, 2005).

Birksted-Breen (2005) discute a existência de uma feminilidade negativa, que se baseia na experiência de falta, e de uma feminilidade positiva, que se refere às várias e ricas experiências relacionadas ao corpo feminino. A autora reforça que, ao falar de positivo, não quer dizer que a experiência será vivenciada como necessariamente boa, pelo contrário: pode estar permeada por inúmeros sentimentos negativos. A nomeação de "positivo” foi utilizada no sentido de contrário ao "negativo", ou seja, atribui à feminilidade algo além de apenas a ausência do pênis: refere-se às "vivências, ansiedades e conflitos relacionados aos órgãos femininos internos e a vivências e fantasias especificamente femininas” (Birksted-Breen, 2005, p. 146). A mencionada autora também ressalta que, tanto a feminilidade positiva quanto a negativa, assumem seu significado a partir da relação com os pais, incluindo a própria inveja do pênis, que está ligada ao relacionamento da menina com a mãe, e sua insatisfação e ciúme.

Além dos aspectos (in)visíveis dos órgãos sexuais e de suas vicissitudes específicas, a representação inconsciente que a mulher desenvolve de seu corpo também está relacionada 
com a importância libidinal que a mãe atribuía à sexualidade da filha, ao seu self físico e psicológico, bem como do quanto transmitiu para a filha seus temores inconscientes que estavam relacionados à sua própria condição feminina (McDougall, 1997). Nas palavras da autora: “As comunicações não-verbais sensuais e, mais tarde, as comunicações verbais entre mãe e filha determinam, em larga medida, se o erotismo oral há de triunfar sobre a agressão oral e se os impulsos eróticos anais hão de tornar-se mais importantes do que os impulsos sádicos anais, ou se vão combinar-se harmoniosamente com eles” (p. 8). Nesse sentido, considera-se que a integração da profunda ligação homoerótica com a mãe é uma das principais áreas de dificuldade para a constituição da sexualidade feminina (McDougall, 1991).

Ligações libidinais e sensuais são tecidas com os pais desde o nascimento, sendo que o bebê vivencia, nos braços da mãe, o primeiro projeto psíquico dos futuros relacionamentos amorosos e sexuais que irá estabelecer ao longo de sua vida. O componente erótico e terno na relação mãe-bebê é constitutivo do “eu feminino” (Ribeiro, 2011), uma vez que é a mãe quem libidiniza o bebê e marca em seu corpo as zonas de prazer e desprazer, erotizando-o. Além do holding materno de Winnicott e da rêverie materna de Bion, a capacidade da mãe de ser uma “sedutora suficientemente boa” (Godfrind, 2011, citado por Ribeiro, 2011) também está em cena quando se trata da sexualidade feminina, ou seja: a capacidade psíquica da mãe erotizar o corpo do bebê de forma adequada, nem excessiva e nem faltante, exerce influência na forma como a menina irá vivenciar sua corporeidade e sexualidade na vida adulta.

Para Halberstad-Freud (2001), o alcance da feminilidade madura - o tornar-se uma mulher independente e emocionalmente equilibrada - depende de que a menina realize duas tarefas: a primeira seria o matricídio, ou seja, a menina deve separar-se parcialmente da imagem materna internalizada; a segunda seria a descoberta de seus próprios sentimentos sexuais e identidade sexual. No entanto, a mencionada autora sugere que há obstáculos para 
tais tarefas, sendo um deles a identificação com a mãe: pode-se afirmar que a primeira relação objetal de toda mulher é homossexual, pois a mãe é o primeiro objeto de amor de todo bebê. No caso da menina, essa relação homossexual a vincula duplamente à mãe, pois pode acontecer que esta última também se identifique à filha, tomando-a como seu duplo e sua extensão. As semelhanças sexuais entre mãe e filha oferecem um espaço amplo para que ambas possam se engajar em identificações mútuas sem separação.

Na realidade, elas [separação e sexualidade] em geral interagem: positivamente quando o desenvolvimento sexual estimula a separação. negativamente quando uma separação bloqueada por sua vez bloqueia o desenvolvimento sexual da menina. (Halberstadt-Freud, 2001, p. 144)

Segundo McDougall (1991, 1997), a atitude do pai também configura um aspecto de importância dessa transmissão de investimento libidinal: a ausência ou o desinteresse do pai para com o bebê, assim como a consagração da mãe como única responsável por ele, instala a possibilidade de que os filhos representem um papel de extensão narcísica da mãe, ou seja, de suprir suas necessidades libidinais e resolver seus problemas inconscientes.

A situação edípica para a menina pode ser um refúgio da relação especular com a mãe, se ali houver abrigo, ou seja, se existir um pai seguro, um porto seguro. Um pai confiável é aquele capaz de apreciar a feminilidade de sua filha, e também de reconhecer e aceitar a interdição dessa relação. (Ribeiro, 2011, p. 28)

A mãe que, de fato, toma o bebê como prolongamento dela mesma, ou como objeto amoroso no lugar do marido, pode estar semeando futuros relacionamentos conflituosos para a filha. Além disso, filhos que estão destinados a encarnar os personagens designados pela mãe são desinvestidos assim que deixam de desempenhar tal função narcísica (McDougall, 1991), o que pode estar relacionado com a impossibilidade do abandono do corpo infantil na AN. 
Segundo Campos et al. (2012), a dinâmica psíquica envolvida nos casos de AN é essencialmente feminina, e tem como elementos centrais a alimentação, o corpo, a sexualidade e a relação mãe e filha. Os autores propõem que os sintomas de TAs podem ser considerados reatualizações de patologias antigas, transmitidas e não elaboradas por várias gerações. As mães de mulheres com TAs tiveram sua feminilidade desvalorizada e prejudicada na relação com suas próprias mães e, portanto, oferecem um modelo identificatório bastante empobrecido enquanto mulheres. A partir da impossibilidade de encontrar um modelo identificatório feminino, acredita-se que as jovens com AN utilizam os sintomas alimentares como forma inconsciente de fazer desaparecer os traços femininos.

O relacionamento que o bebê partilha com sua mãe nos primeiros meses de vida proporciona a formação das imagens somatopsíquicas que estão destinadas a se tornarem representações mentais de seu corpo feminino. Entretanto, o pai também desempenha um papel crucial nesse momento, uma vez que a menina necessita perceber que ele valoriza e aprecia a feminilidade da filha, assim como a de sua esposa. Discursos depreciativos dos pais a respeito da sexualidade da filha afetam sua imagem narcísica e podem ser transferidos para o significado que ela atribui à feminilidade (McDougall, 1997).

Gaspar (2010) relaciona diretamente o “esquecimento” do pai - muito comum nos casos de TAs, como decorrência da fusão mãe-filha - com questões de resistências ao desenvolvimento psicossexual. Para a mencionada autora, tal “esquecimento” mantém relação com um retorno aos primórdios da vida psíquica, à fase pré-edípica que antecede a entrada do pai na relação do bebê com a mãe e impede que a sexualidade - aspecto fundamental na constituição subjetiva - se desenvolva. Para Chabert (2004):

[...] parece que o esquecimento do pai tem como primeiro efeito manter um sistema eminentemente narcísico e fechado, excluindo justamente todo sinal de diferença, porque evoca muito rápido a destruição de uma unidade cuja preservação constitui uma preocupação primordial: alguma coisa, que se inscreveria na 
pulsionalidade autoconservadora, lutando avidamente contra todo surgimento de um sexual ameaçador. (p. 13)

Durante a adolescência, a menina vivencia um bombardeio pulsional (Miranda, 2007) e uma série de manifestações no corpo, que dão origem aos atributos corporais da mulher adulta. Diante das modificações incontroláveis do corpo, a menina experiencia impressões sensoriais e emoções que podem reavivar conflitos primordiais e colocá-la em confronto com o luto pela perda do mundo infantil, a começar pela percepção intensa de que seu corpo de criança está sendo abandonado e substituído por novos traços. Como consequência, juntamente com a percepção da perda do corpo infantil, há também a perda dos pais da infância, ou seja, da relação fusional com a mãe. Esse momento do desenvolvimento psicossexual da menina remete a representações inconscientes maternas em relação à sua própria feminilidade e a da filha, despertando angústias de separação e abandono (Miranda, 2007).

De acordo com Lawrence (1991) e McDougall (1991, 1997), se a mãe tem a disponibilidade mental de tolerar as mudanças no corpo da filha e recepcionar o despertar de sua feminilidade, então a adolescente poderá se adaptar às novas manifestações que se expressam em seu corpo e, assim, poderá sustentar a vivência da mulher que surge em si mesma. Entretanto, no caso dos TAs, as mães apresentam dificuldades em se separar das filhas, de forma que aceitar o despertar da feminilidade destas se torna uma experiência intolerável. Ao considerar que há uma contrapartida da filha, que também vivencia a angústia de separação e não quer abandonar a mãe, Miranda (2007) sugere que a recusa alimentar pode ser considerada como uma maneira de conter a separação, obliterando o intervalo eu-outro. Nesse sentido, os TAs podem ser compreendidos como tentativas da menina de continuar indiferenciada e assexuada, uma criança fusionada à mãe, buscando assim evitar uma possível desorganização e fragmentação do self, decorrentes do afastamento (sentido como abandono) da figura materna. 
A adolescência é uma fase em que conflitos recalcados na infância emergem e são repetidos, em uma tentativa inconsciente de elaboração (Gaspar, 2010). Não é a toa que os TAs eclodem, em sua grande maioria, em adolescentes do sexo feminino. “o sexo psíquico está longe de ser o simples decalque do sexo anatômico” (André, 2001, p. 34).

Ninguém nasce homem ou mulher, torna-se homem ou mulher ao atravessar o percurso edípico. (Kehl, 2008, p. 9)

A puberdade e a entrada na adolescência, marcada pela ocorrência da menarca, engloba uma série de processos fisiológicos e anatômicos, envolvidos na maturação genital: ganho de gordura em regiões significativamente sexuais, tais como seios e quadris; peso, cintura, rosto e pele sofrem alterações; o próprio sangue menstrual passa a aparecer com frequência mensal. Tais mudanças fisiológicas despertam a sexualidade pubertária e reverberam em processos psíquicos, uma vez que trazem à tona sentimentos edipianos, castração, frustração de desejos de maternidade e, para muitas jovens, sentimentos de humilhação (Ávila, 1996).

Em consonância com as ideias trazidas por Ávila (1996), Gaspar 2010 aprofunda a questão dos conflitos edípicos não elaborados psiquicamente, que são revividos na adolescência. Os entraves relativos ao desenvolvimento da sexualidade em jovens com TAs parecem configurar, segundo a autora, um tipo de resposta defensiva ao encontro com a genitalidade, momento em que sentimentos que ficaram para trás, aguardando solução, são retomados. Há uma recusa inconsciente à saída do mundo infantil e, consequentemente, à entrada na adolescência.

Em suma, os TAs envolvem organizações defensivas poderosas, nas quais a psique funciona de forma a perverter o desenvolvimento físico e emocional, a fome, o desejo e os atrativos femininos, que passam a caminhar no caminho contrário ao da natureza, chocandose com o despertar da genitalidade da menina (Miranda, 2007). 


\section{Capítulo 4. Transtornos alimentares e sexualidade: Análise da produção científica}

Partindo-se da questão temática: “De que forma a vivência da sexualidade e da feminilidade se articula com o desenvolvimento e manutenção dos sintomas de TAs?”, buscou-se sintetizar a produção científica nacional e internacional acerca do tema em questão, por meio da realização de uma revisão integrativa da literatura, descrita no Anexo I. Os dados oriundos da revisão integrativa serão expostos descritivamente a seguir.

A literatura científica especializada apresenta uma consonância no que concerne ao fato dos TAs serem considerados "problemas femininos” (Cella, Iannaccone, \& Cotrufo, 2013). Os autores pontuam que as mulheres são mais vulneráveis ao desenvolvimento desses transtornos, sendo que apenas 5-10\% dos pacientes com AN e 10-15\% dos pacientes com BN são do sexo masculino. Tais diferenças de gênero entre indivíduos que apresentam comportamentos alimentares disfuncionais pode ser melhor explicados pelos construtos de feminilidade e masculinidade. O estudo de Cella, Iannaccone e Cotrufo (2013) evidenciou que os participantes com traços femininos, independentemente do gênero biológico e da orientação sexual, apresentaram índices mais altos de sintomas de TAs do que participantes com traços de masculinidade, androgenia e/ou indiferenciação sexual. Homossexualidade masculina - que apresenta traços femininos acentuados - foi associada com maior insatisfação corporal e comportamentos alimentares anormais. De forma geral, concluiu-se que a feminilidade pode ser considerada como fator de risco para TAs, e que homens com transtornos de identidade de gênero podem ser mais vulneráveis a patologias alimentares do que homens heterossexuais.

Ao comparar características psicológicas, comportamentais e traços de identidade de gênero entre mulheres com e sem TAs, alguns autores (Behar, Barrera, \& Michelotti, 2003) perceberam que as mulheres com TAs se identificaram mais com o estereótipo tradicional do 
gênero feminino do que as mulheres sem esta patologia. Além disso, as mulheres acometidas foram caracterizadas como mais propensas a serem femininas, infantis, temperamentais, ambiciosas, desejosas de receberem elogios e de possuírem posição social elevada. Já as mulheres sem patologia foram apresentadas como mais felizes, confiantes, compreensivas, independentes, autossuficientes e capazes de tomar decisões. A feminilidade, portanto, emergiu como principal traço da identidade de gênero em pacientes com TAs. Por identidade de gênero os autores compreendem o estereótipo adquirido pelos indivíduos a partir do sistema de crenças e comportamentos atribuídos ao sexo masculino e feminino pela sociedade contemporânea, sendo que tal estereótipo pode se tornar bastante aversivo para alguns indivíduos, estando relacionados a insatisfação corporal e a patologias alimentares. Nesse sentido, o estudo de Behar, Barrera e Michelotti (2003) aponta para a significativa influência que o contexto sociocultural no qual os indivíduos estão inseridos exerce sobre a saúde mental e, consequentemente, sobre o desenvolvimento de quadros psicopatológicos, sendo a magreza e a beleza femininas consideradas os ideais de sucesso mais enfatizados pela cultura.

Segundo Hepp, Spindler e Milos (2005), o papel de gênero pode ser definido como a posição que o indivíduo assume como masculino ou feminino, tomando como base os conceitos socialmente construídos acerca do estereótipo cultural desses construtos, ou seja, os comportamentos, atitudes, interesses e características de personalidade considerados tipicamente masculinos ou femininos. No entanto, os autores propõem que masculino e feminino não são extremos de um continuum, mas, ao contrário, o papel de gênero de um indivíduo pode integrar traços de ambos. Considerando-se que o papel de gênero remete à autopercepção, autoestima, imagem corporal e satisfação corporal - aspectos psicológicos centrais nos TAs -, Hepp, Spindler e Milos (2005) realizaram um estudo que teve como objetivo investigar a relação entre papel de gênero e TAs. Diferentemente dos estudos mencionados anteriormente, os resultados do estudo de Hepp, Spindler e Milos (2005) 
evidenciaram que a feminilidade não estava diretamente relacionada aos sintomas centrais dos TAs, mas apenas a sintomas psicopatológicos não especificados relacionados a esses quadros. Portanto, os resultados não corroboraram a hipótese de que a feminilidade configura um fator de risco para a ocorrência de TAs. A masculinidade, por sua vez, foi definida como fator de proteção contra TAs, em convergência com a literatura.

Tomando-se por base o pressuposto de que dificuldades para desenvolver uma identidade sexual exercem importante influência no processo de adoecimento e de precipitação dos TAs, Januszek (2007) buscou investigar componentes da identidade sexual de adolescentes com AN, comparando-as com adolescentes sem condições clínicas (grupo controle). Tais componentes envolviam: o “Eu real”, o desejado "Eu ideal” e o normativo "Eu ideal”. Em relação ao “Eu real”, as adolescentes com AN se consideravam: menos sociáveis, seguras de si, emocionalmente fortes, com menos senso de humor e menor tendência a ter experiências sexuais. Consideravam-se menos corajosas, animadas, hábeis ou enérgicas do que as adolescentes sem condição clínica. Também se descreveram com mais características estereotípicas femininas: se percebiam mais chorosas, fracas e carentes, tímidas, caprichosas, submissas e sensíveis. Em relação ao desejado "Eu ideal”, as adolescentes de ambos os grupos declararam desejar ter mais características relativas ao estereótipo masculino do que ao feminino. Concluiu-se que a baixa autoestima na área da sexualidade tem relação com as discrepâncias entre o “Eu real”, o desejado "Eu ideal” e o normativo "Eu ideal” e pode dificultar que as adolescentes com AN desenvolvam um conceito coerente de si mesmas enquanto mulheres, o que poderia, por sua vez, dificultar o desempenho de papéis sexuais e o alcance de uma identidade sexual madura. Nesse sentido, uma das possíveis formas de lidar com tais dificuldades seria concentrar-se apenas nos atributos externos de gênero, tais como a aparência, e também aceitar o papel de pessoa adoecida que, até certo ponto, alivia a necessidade de assumir papéis sexuais. 
A literatura científica apresenta uma convergência consolidada no que diz respeito à associação entre sexualidade e insatisfação corporal, realização de dietas e compulsão alimentar (Meyer, Blisset, \& Oldfield, 2001). Tal associação parece ser mais complexa quando envolve a sexualidade feminina, uma vez que indivíduos com altos índices de feminilidade apresentam também altos índices de comportamentos alimentares restritivos, enquanto que indivíduos com altos índices de masculinidade apresentam baixos índices desses comportamentos. Tal afirmação pressupõe que a feminilidade - acentuada na homossexualidade masculina e embotada na homossexualidade feminina - mantém relação direta com a predisposição para a ocorrência de TAs.

Por “altos índices de feminilidade”, compreende-se que Meyer, Blisset e Oldfield (2001) procuraram se referir a indivíduos - não apenas mulheres, mas também homens homossexuais - que endossavam as normais tradicionais de gênero feminino, tais como dependência e passividade (Green, Davids, Skaggs, Riopel, \& Hallengren, 2008). Mahalik et al. (2005), ao desenvolverem o Inventário de Conformidade com as Normas Femininas (Conformity to Feminine Norms Inventory - CFNI), definiram a feminilidade como um construto multidimensional composto por atitudes e comportamentos que diferem amplamente entre as mulheres dependendo de seus padrões pessoais de aceitação e endosso às seguintes oito normas sociais tradicionalmente femininas: Agradável em relacionamentos, Envolvimento com crianças, Magreza, Fidelidade sexual, Modéstia, Envolvimento em relacionamento romântico, Comportamento doméstico e Investimento em aparência. A partir de seus padrões individuais de funcionamento emocional, cada mulher pode ter dificuldades para endossar certos papéis tradicionalmente femininos, enquanto que pode ter acentuada facilidade para endossar outros (Green et al., 2008). Essa afirmação tem importância prática significativa, uma vez que o endosso a certas normas femininas pode estar associado a altos índices de TAs, tais como magreza e investimento em aparência. Entretanto, Green et al. 
(2008) e Mahalik et al. (2005) sugerem que outras normas femininas tradicionais não foram associadas com a sintomatologia de TA.

De forma semelhante ao estudo de Meyer, Blisset e Oldfield (2001), Moore e Keel (2003) partiram do pressuposto consolidado pela literatura científica de que a homossexualidade feminina - na qual o traço de feminilidade é acentuado - atua como fator de proteção contra a ocorrência de sintomas de TAs, assim como a masculinidade. No entanto, Moore e Keel (2003) também apontaram resultados de pesquisas que contradizem esses pressupostos, sugerindo que algumas mulheres homossexuais apresentam altos índices de compulsão alimentar. Essa divergência na literatura pode ser explicada pela diferença entre as amostras estudadas pelos vários estudos que abordam a questão da sexualidade nos TAs, o que indica que as mudanças ocorridas ao longo do ciclo de vida podem afetar a vulnerabilidade para o desenvolvimento desses quadros. Nesse sentido, os autores buscaram testar a hipótese de que a associação entre orientação sexual e patologias alimentares nas mulheres é influenciada pela idade. Os resultados do estudo não corroboraram tal hipótese. Mulheres homossexuais relataram menos desejo de emagrecer e menos uso do exercício físico para perder peso quando comparadas a mulheres heterossexuais. No entanto, não houve diferenças significativas nas escalas Bulimia, Body Dissatisfaction e Weight Concern do EDI2, o que sugere que a orientação sexual pode influenciar apenas alguns tipos de atitudes e comportamentos alimentares disfuncionais em mulheres. Foram encontradas mais semelhanças do que diferenças entre mulheres homo e heterossexuais.

Por meio de um estudo exploratório e descritivo, de reflexão teórica, Ghizzani e Montomoli (2000) buscaram investigar o tema da sexualidade em mulheres com AN. Os autores abordaram vários aspectos que permeiam o quadro, enfatizando sobretudo a questão da imagem corporal, uma vez que as complexas atitudes das mulheres com AN frente aos seus corpos remetem à forma como elas lidam com sua sexualidade, aceitando ou recusando- 
a. A imagem corporal desempenha papel crucial nas atitudes frente às relações sexuais e, portanto, não é surpreendente que mulheres com AN apresentem dificuldades para se expressarem sexualmente, ou mesmo para desenvolverem relacionamentos íntimos, mantendo-se isoladas, ansiosas e emocionalmente retraídas. Temas como abuso sexual, capacidade de lidar com eventos estressores, perfeccionismo, padrões familiares, atitudes psicossexuais, entre outros, também foram discutidos pelos autores. Concluiu-se que a AN pode ser considerada um quadro psicopatológico multidimensional, caracterizado por uma variedade de transtornos orgânicos, psicodinâmicos e endocrinológicos. Os diferentes papéis desempenhados pelas alterações endocrinológicas e pelos comportamentos disfuncionais na promoção e/ou manutenção dos sintomas psicológicos e orgânicos são impossíveis de serem diferenciados, e muitos desses sintomas (especialmente as atitudes sexuais) fazem parte dos comportamentos típicos da AN, ou secundários à perda de peso e à depressão.

Com objetivo semelhante ao da pesquisa de Ghizzani e Montomoli (2000), o estudo de Romejko-Borowiec (2004) também investigou o desenvolvimento sexual de mulheres com TAs. Os autores realizaram uma vasta revisão da literatura científica acerca do tema, além de um estudo empírico no qual avaliaram 73 mulheres jovens e adultas com TAs, comparando-as com 31 mulheres sem condições clínicas. Os resultados corroboraram a literatura no que concerne à relação entre TAs e disfunção sexual. Os sintomas de TAs parecem estar relacionados com a adequação às normas impostas pela tradição e cultura em relação aos papéis femininos, sendo considerados meios inconscientes de resolução de conflitos de identidade sexual. Os autores consideram que, ao desenvolver um transtorno desse tipo, as mulheres podem evitar e/ou prorrogar confrontar-se com os papéis exigidos das mulheres adultas.

Em termos de relacionamentos afetivos e atividades sexuais propriamente ditas, Pinheiro et al. (2010) realizaram um estudo com 242 mulheres acometidas por TAs, dentre as 
quais $98 \%$ informaram terem vivenciado relacionamentos íntimos, sendo que em 55\% desses relacionamentos houve relação sexual, e $87 \%$ da amostra referiram ter tido relacionamentos significativos com diversos níveis de estabilidade ao longo da vida. Aproximadamente 60\% das participantes com TAs referiram perda da libido e ansiedade relacionada à sexualidade. Mulheres com AN demonstraram maior prevalência de perda da libido do que mulheres com BN e TA não especificado. Ausência de relações sexuais foi associada com baixo IMC ao longo da vida e ocorrência precoce do TA; perda da libido foi associada com baixo IMC, altos níveis de consciência interoceptiva e traços de ansiedade; e ansiedade sexual foi associada com baixo IMC, condutas de evitação de danos e ineficácia. A incidência de disfunções sexuais nas mulheres com TAs foi maior do que na amostra normativa. A partir dos dados demonstrados pelo estudo de Pinheiro et al. (2010), nota-se que o funcionamento sexual de mulheres com TAs encontra-se comprometido por sentimentos de ansiedade, retraimento, condutas de evitação e perda da libido. No entanto, considera-se que o estudo apresenta lacunas no sentido de fornecer subsídios para a compreensão da forma como esses sentimentos surgem e se manifestam no psiquismo dessas mulheres, comprometendo a vivência da sexualidade.

Kaltiala-Heino, Rimpelä, Rissanen e Rantanen (2001) buscaram examinar as associações entre puberdade precoce, desenvolvimento sexual precoce e psicopatologias alimentares do tipo bulímico - ou seja, distúrbios caracterizados por compulsão e purgação alimentares, mas que não haviam sido diagnosticados como BN por não se tratar de uma amostra clínica - em adolescentes entre 14 e 16 anos, de ambos os sexos. A amostra consistiu em 19321 adolescentes do sexo masculino e 19196 do sexo feminino recrutados em 258 escolas finlandesas. Os resultados indicaram que as adolescentes que apresentaram sintomas bulímicos também tiveram menarca precoce e experiências sexuais precoces. Dentre os adolescentes do sexo masculino, o início das ejaculações na idade normativa foi considerado 
fator de proteção contra a ocorrência de traços bulímicos, e o risco foi considerado elevado para aqueles que apresentavam início precoce ou tardio. Conclui-se que, para que se possa desenvolver práticas preventivas para TAs e intervenções precoces, deve-se voltar a atenção para adolescentes com maturação precoce (no caso das meninas) e/ou tardia (no caso dos meninos), assim como para o início prematuro das atividades sexuais.

Ruuska, Kaltiala-Heino, Koivisto, \& Rantanen (2003) realizaram um estudo que teve como objetivo avaliar possíveis relações entre TAs, puberdade e atitudes frente à sexualidade em uma amostra de 57 adolescentes do sexo feminino com AN e/ou BN. Adolescentes com BN apresentavam ocorrência da menarca - que marca a entrada na puberdade e, portanto, o início das vivências relativas à sexualidade, no qual a menina deve se adaptar às mudanças no corpo e às novas demandas da maturidade sexual - em idades mais precoces do que adolescentes com AN e/ou sem TAs. No que concerne às atitudes frente à sexualidade, as adolescentes com AN apresentavam atitudes mais negativas do que aquelas com BN, além de também apresentarem menor número de relacionamentos afetivos e interesse em namoro. Hipotetiza-se que as diferenças entre os traços de personalidade existentes entre mulheres com AN e BN estejam relacionados às diferenças que essas mulheres apresentam nas formas de lidar com os desafios relacionados ao desenvolvimento sexual típicos da adolescência, uma vez que tais formas de manejo dos desafios envolvem subjetividades pessoais e se reportam à interferência da organização emocional na forma de reagir às experiências (Leonidas, Crepaldi, \& Santos, 2013).

Ainda considerando a influência dos traços de personalidade de mulheres com AN e BN, Eddy, Novotny e Westen (2004) investigaram a ótica de profissionais que atuavam na área dos TAs, buscando compreender a visão desses profissionais acerca da articulação desse traços de personalidade com a sexualidade das pacientes. Os profissionais relataram que pacientes emocionalmente constritos e supercontrolados, que tendem a restringir a 
alimentação e não têm consciência interoceptiva de sensações de fome, apresentam comportamentos sexuais restritivos bastante similares à restrição alimentar. Da mesma forma, pacientes emocionalmente descontrolados e desorganizados, que tendem a apresentar ocorrência de compulsão alimentar e purgação, manifestam comportamentos sexuais impulsivos e autodestrutivos, semelhantes às atitudes alimentares. Portanto, é possível considerar que a forma como as mulheres acometidas por TAs lidam com a alimentação e com a sexualidade seja um reflexo, de modo geral, da desorganização psíquica gerada pela dificuldade de manejo de conflitos e frustrações intensas.

No que concerne às experiências sexuais indesejadas, o estudo de Castellini et al. (2013) teve por objetivo avaliar o curso longitudinal do funcionamento sexual, assim como a relação entre mudanças observadas na psicopatologia e história de abuso na infância com o funcionamento sexual em pacientes com AN e BN. Participaram da pesquisa 27 mulheres com AN e 31 com BN, que foram submetidas a um ano de tratamento com Terapia CognitivoComportamental (TCC), tendo sido avaliadas no início e ao final do tratamento. A avaliação indicou que as pacientes apresentaram melhora significativa em todos os domínios do funcionamento sexual, exceto aquelas que tinham histórico de abuso sexual. A redução da gravidade do TA estava diretamente associada à melhora do funcionamento sexual, novamente com exceção das participantes com histórico de abuso sexual. Concluiu-se que as psicopatologias alimentares podem ser consideradas fatores de manutenção da disfunção sexual em indivíduos acometidos por TAs. Indivíduos com histórico de abuso sexual representam uma subpopulação de pacientes com profundo mal-estar envolvendo a percepção corporal e o funcionamento sexual. Esse mal-estar parece não ter sido adequadamente abordado durante a intervenção de TCC. Porém, os autores ressaltam que os resultados devem ser considerados preliminares, dado o pequeno número de participantes da amostra. 
Os aspectos socioculturais do feminino e suas articulações com os sintomas de TAs também foram abordados por alguns artigos. Hoskins (2002) realizou um estudo descritivo e exploratório acerca da formação da identidade feminina, criticando a permanência ortodoxa das teorias psicanalíticas clássicas do self, não obstante as teorias pós-modernas terem desafiado as formulações antigas ao dar ênfase à importância dos processos de autocriação em relação à cultura ou discurso. Na concepção pós-estruturalista, a sexualidade é pensada como uma multiplicidade de combinações que não surgem a partir da imposição psicossocial. Critica-se a concepção essencialista de uma identidade fixa e congelada, presente em teorias que lançam um olhar estereotipado sobre os indivíduos que manifestam sexualidades desviantes da condição normativa. Apesar dos inúmeros estudos acerca dos TAs que têm sido desenvolvidos nos últimos anos, a autora pontua que muito tem sido trabalhado em termos de patologias individuais, negligenciando a compreensão das vivências das jovens como membros ativos da sociedade contemporânea, com todas as exigências para que as mulheres sejam belas, magras e bem-sucedidas. Ou seja, é preciso compreender de que forma a cultura influencia a vida de adolescentes do sexo feminino, considerando-se que os TAs afetam aspectos centrais do desenvolvimento da identidade. Dentre as realidades pós-modernas que podem afetar a formação da identidade, a autora menciona: a forma como a sexualidade é retratada pelos programas de televisão; o aumento do número de cirurgias plásticas e a facilidade para modificar o corpo; exposição a novas realidades a partir do uso da internet; entre outros. Sugere-se a utilização de novas teorias do self na pesquisa e na prática, de forma a ampliar a compreensão dos profissionais de saúde a respeito do modo com as identidades são constituídas nas sociedades pós-modernas.

Ainda considerando a questão da construção da identidade enquanto fenômeno psíquico e sociocultural, Heenan (2005) defende a abordagem psicanalítica feminista, adaptada do livro Fat Is a Feminine Issue, de Susie Orbach (1978), no qual os distúrbios da 
alimentação são relacionados ao modo como as mulheres vivenciam a própria feminilidade, sendo que tais vivências, quando se tornam intoleráveis para o psiquismo, são cindidas e projetadas em nível do corpo. Heenan desenvolveu um estudo exploratório e descritivo, que teve como objetivo explorar o material de um grupo de terapia psicodinâmica feminista para mulheres com diversos problemas alimentares, buscando entrelaçar tanto os conteúdos discursivos quanto os inconscientes, para compreender a função do peso corporal para o gênero feminino. O estudo de Heenan se aproxima da pesquisa de Hoskins (2002), na medida em que trabalha com o conceito de corpo como interface entre a mente consciente e inconsciente, inserida em um mundo tanto interno quanto externo (social).

Heenan (2005) sugere que, para muitas mulheres, é comum buscar a felicidade simbólica que a dieta e o corpo esbelto representariam, ou seja, atualmente, as mulheres crescem em um meio sociocultural no qual felicidade e bem-estar são o mesmo que serem magras. Apesar das melhoras trazidas pela abordagem psicanalítica feminista, a autora finaliza o estudo afirmando que possibilitar a construção de uma relação satisfatória de mulheres com TAs com seus corpos é algo extremamente desafiador. Para que essa relação possa ser conquistada, as terapias devem ser combinadas com abordagens cognitivocomportamentais.

Por fim, foi selecionado apenas um estudo (Lane, 2002), de caráter exploratório e descritivo, que teve como objetivo apresentar uma reflexão teórica psicanalítica acerca da AN e sua relação com outros problemas de autoagressão, tais como masoquismo e automutilação. O autor parte da psicanálise, que considera que a AN origina-se na relação infantil da criança com a mãe, que resulta em dificuldades na separação da dupla e no desenvolvimento de um self autônomo. A jovem mulher passa a se autoagredir como forma de expressar conflitos internos no corpo, tanto de forma simbólica quanto como uma forma de descarregar tensões e 
se autoconfortar, direcionar a dor mental para o corpo, autopurificar-se dos impulsos corporais, ou como forma passivo-agressiva de vingar-se das figuras parentais.

De forma geral, o autor sugere que tanto pacientes com TAs quanto autoagressores provêm de famílias disfuncionais, com mães altamente controladoras, pais (genitores do sexo masculino) ausentes e um histórico de eventos traumáticos. São pacientes depressivas e obsessivas, excessivamente apegadas às mães, que por sua vez desencorajam suas tentativas de emancipação. Os sintomas teriam a função inconsciente de manter as mulheres infantilizadas, com sentimentos negativos frente à menstruação, maturidade sexual, desenvolvimento corporal e feminilidade em geral. Tais sintomas englobam comportamentos autodestrutivos, que teriam como objetivo remover pensamentos sobre sexo, tentações e atividades. Tanto os TAs quanto as automutilações configuram formas deliberadas de autoagressão, que funcionam como forma de catarse, "purificando" a jovem e modulando estados de ansiedade, tensão sexual, raiva e vazio dissociado, despertando sentimento de alívio descrito como "quase físico” (Lane, 2002). Nesse sentido, as pacientes em questão fazem uso de substitutos que previnem a maturação e o desenvolvimento da feminilidade, fazendo com que a jovem regrida a fases pré-genitais do desenvolvimento psicossexual, com uso abundante de defesas típicas desse estágio, distanciando-a por um tempo da responsabilidade de responder às demandas da puberdade e da maturidade sexual. 


\section{Capítulo 5. Feminilidade: o desenvolvimento da sexualidade feminina e a maternidade}

Segundo Emidio (2008), a teoria freudiana foi desenvolvida a partir de uma visão falocêntrica, ou seja, o homem era o detentor do falo e invejado pela mulher. Esta última vive a falta e o desejo de completude ao longo de toda a sua vida, até o momento da gestação e concepção de um filho, que passa a ocupar o lugar de objeto fálico da mulher. Por considerar que a mulher atinge sua completude na maternidade, esta foi amplamente valorizada e explorada pela literatura psicanalítica, uma vez que encontra-se intimamente relacionada com as vicissitudes da sexualidade feminina.

Em seus textos “Feminilidade” (1976/1933) e "Sexualidade feminina” (1972/1931), Freud propõe três destinos possíveis para a inveja do pênis na mulher - ou, em outras palavras, para o confronto com a castração -, a saber: a inibição sexual, ou frigidez; complexo de masculinidade, ou virilidade; maternidade, sendo esta última a única possibilidade de se tornar mulher efetivamente (Birman, 1999), devido à sensação de completude que acompanha a gestação de um filho. Não se pode afirmar que o ideal da maternidade foi significativamente modificado desde a época de Freud, mesmo com as grandes mudanças socio-históricas ocorridas desde então (Emidio, 2008). Esse ideal continua atrelado ao feminino, o que pode ser observado na desaprovação social que emerge quando uma mulher afirma não desejar ser mãe. Segundo Emidio (2008), em tal situação, é como se a mulher “estivesse fugindo de seu papel social e não obedecendo à regra fomentada pela psicanálise freudiana de que o único caminho para tornar-se mulher se dá pela via da maternidade” (p. 76).

Em contrapartida, Badinter (1985) relativiza o paradigma freudiano ao afirmar que há exceções à regra do amor materno, uma vez que esse amor envolve vários aspectos da experiência da feminilidade, desde fatores constitucionais da personalidade de cada mulher até fatores socioculturais. A referida autora propõe ainda que o amor materno é um 
sentimento humano e, como todo sentimento, é incerto, frágil e imperfeito; pode estar, ou não, inscrito na natureza feminina, e pode variar em termos de intensidade para cada mulher. Nesse sentido, indo contra a perspectiva biológica, pode-se dizer que o interesse e a dedicação à criança podem se manifestar ou não: mãe não é aquela que concebe um filho, mas sim, aquela que deseja um filho, que tem a possibilidade de amá-lo e que se identifica com o papel de mãe (Baptista, 1995; Matsumoto, 2009).

De forma convergente com as concepções de Badinter (1985) e Baptista (1995), Emidio (2008) afirma que hoje em dia já se pode considerar a vivência da feminilidade como independente da vivência da maternidade. Em épocas anteriores, o desejo de ser mãe também estava relacionado a questões sociais, uma vez que a maternidade era a única forma que a mulher tinha para adquirir importância na família e no meio social. Entretanto, atualmente a feminilidade está relacionada a várias singularidades da mulher, que implicam em possibilidades de escolha na vida, e uma delas pode ser a de não ser mãe (Emidio, 2008).

Para Soifer (1980), a descoberta da gravidez e os momentos iniciais da gestação despertam sentimentos bastante ambivalentes: por um lado, o desejo de ter a criança e a aceitação de todas as mudanças envolvidas no cuidado a ela; e, por outro, a rejeição à gravidez, que geralmente encontra-se relacionada à intensificação das vivências persecutórias frente à maternidade, as quais se originam em sentimentos de culpa infantil: as fantasias de ataque à própria mãe e os desejos de ocupar seu lugar (Soifer, 1980). Ou seja, a vivência da maternidade coloca a mulher frente a frente com questões edípicas muito primitivas, que podem despertar angústias e dificuldades de aceitação da gravidez.

A concepção de uma criança é sempre precedida por uma série de fantasias e expectativas maternas e paternas, sendo que tais expectativas podem ser positivas ou negativas, dependendo do quanto aquele bebê foi desejado, quão preparados os pais se sentem para prover cuidados a ele, entre outros. Há, portanto, um lugar preestabelecido para o bebê 
antes mesmo de seu nascimento. Considera-se que o lugar reservado ao bebê no psiquismo dos pais influencia diretamente o desenvolvimento da criança, que crescerá sob a regência do amor, das fantasias e das expectativas depositadas pelos pais (Matsumoto, 2009).

O desejo de ter filhos encontra-se intimamente relacionado aos desdobramentos da sexualidade na mulher, tendo início na primeira infância, na relação primária com a mãe, e constitui uma questão central no psiquismo feminino e na construção da feminilidade (Ribeiro, 2011). Ao pesquisar as vicissitudes do desejo feminino de ter um filho, a referida autora constatou que a maternidade tem a função de trazer mudanças nas identificações da mulher com a figura materna. Tais identificações ocorrem ao longo de toda a vida e são frequentemente reeditadas.

Meira (2005) sugere que a mulher precisa passar por um intenso processo de adaptação para se tornar mãe, que implica em desenvolver uma nova identidade. Essa nova identidade - a de figura materna - inclui não apenas a ressignificação da própria feminilidade, mas também a obrigação de prover cuidados a um filho e servir de modelo para que esse filho possa se desenvolver de forma emocionalmente saudável. A facilidade ou dificuldade no exercício da parentalidade depende diretamente de quanto os pais se sentem preparados para as mudanças no relacionamento conjugal, no estilo de vida e nos seus próprios papéis desempenhados dentro da família, que sofrerão mudanças a partir da integração de um novo membro (Matsumoto, 2009).

Em suma, os processos vivenciados pelos pais na transição para a parentalidade podem afetar diretamente as relações iniciais com o bebê e seu desenvolvimento psicológico, uma vez que pais emocionalmente equilibrados proporcionam as condições adequadas para a saúde mental da criança. No entanto, a psicanálise enfatiza a importância do papel da mãe enquanto função estruturante do psiquismo da criança: para Freud (1996/1938), a relação com 
a mãe serve de modelo para todos os relacionamentos afetivos que o filho irá estabelecer ao longo de sua vida.

O exercício da maternidade consiste em uma tarefa bastante complexa para a mulher, pois envolve sentimentos muito ambivalentes: por um lado, a mulher vivencia as gratificações e alegrias decorrentes do ser mãe, mas, por outro lado, vivencia angústias e conflitos internos, que estão relacionados à qualidade da maternagem que a própria mãe recebeu enquanto filha. Ou seja, a forma como a mulher irá experienciar a maternidade depende da relação que ela mesma estabeleceu com o objeto materno introjetado, a “mãe interna” (Klein, 1934/1981), pois tal relação é fundamental na organização dos sentimentos e atitudes da mulher no desempenho da função materna. Para De Felice (2006), quando não há uma "mãe boa” internalizada - o que geralmente ocorre quando há predomínio de sentimentos de hostilidade e desconfiança em relação à mãe interna (Matsumoto, 2009) -, a vivência da função materna será mais provavelmente repleta de angústias e sentimentos de culpa do que por gratificações e alegrias. Conclui-se, então, que a relação com a figura materna introjetada é determinante na experiência emocional da mulher durante a gravidez e ao longo da maternidade.

Em um estudo sobre transmissão psíquica transgeracional com jovens mulheres acometidas por TAs, suas mães e avós, Valdanha, Scorsolini-Comin e Santos (2013) perceberam que as mães das jovens haviam herdado de suas próprias mães a maneira de exercer a maternidade. Os cuidados maternos, para as mães e avós do estudo, englobavam cuidados concretos relacionados à higiene das filhas, alimentação e afazeres domésticos. Tais cuidados foram transmitidos entre as gerações, com pouca possibilidade de elaboração: tratava-se de uma maternagem aprendida em momentos muito precoces do desenvolvimento, como consequência de injunções parentais e necessidades familiares. As mães não tiveram a possibilidade de desenvolver a maternagem de forma gradual, no tempo de maturação que essa função exige para que seja desempenhada de forma saudável. A mencionada autora 
considera que os TAs, muitas vezes, emergem com o intuito inconsciente de quebrar a homeostase da família e dos padrões de maternagem reproduzidos em sucessivas gerações pela via transgeracional.

De maneira geral, pode-se afirmar que a vivência da maternidade é uma experiência única na vida de cada mulher, influenciada pelas configurações afetivas de seu universo mental, que englobam os afetos, angústias, relações objetais, sua história pregressa vivida com a própria mãe e suas experiências infantis de cuidados (De Felice, 2006; Matsumoto, 2009). Nota-se que tanto os aspectos saudáveis do psiquismo da mãe podem atuar no desempenho da função materna, quanto os primitivos e não elaborados. Assim, a maternidade enquanto experiência saudável, feliz e gratificante depende da possibilidade do predomínio das partes mais sadias da mente atuando sobre a experiência da maternagem (De Felice, 2006). 


\section{JUSTIFICATIVA}

Segundo Wiederman, Pryor e Morgan (1996), a literatura clássica acerca dos TAs (Lasègue, 1873/1964; Janet, 1929; Waller, Kaufman, \& Deutsch, 1940, mencionados por Wiederman, Pryor, \& Morgan, 1996) reconhece a ocorrência de problemas relacionados à sexualidade como possíveis fatores causais desses quadros. O papel de gênero diz respeito ao modo como o indivíduo se posiciona no mundo, dentro das dimensões masculina e/ou feminina, independentemente do sexo biológico. No caso das mulheres, a vivência do papel de gênero feminino (ou seja, da própria feminilidade) está relacionada, de forma geral, à auto percepção, autoestima, imagem corporal e satisfação corporal, que configuram aspectos psicológicos centrais dos TAs (Hepp, Spindler, \& Milos, 2005). Nesse sentido, considera-se que ampliar a compreensão acerca do impacto da sexualidade no desenvolvimento e manutenção dos TAs pode contribuir para o aprimoramento da assistência.

Estudos que abordam a temática da sexualidade no contexto dos TAs apresentam dados convergentes a respeito das diferenças entre mulheres com $\mathrm{AN}$ e $\mathrm{BN}$, indicando que a AN estava relacionada às atitudes negativas frente à sexualidade, baixa frequência de atividades sexuais e ausência de relacionamentos afetivos, enquanto que a BN estava relacionada à atividades sexuais precoces e frequentes, e menarca precoce (Eddy, Novotny, \& Westen, 2004; Kaltiala-Heino et al, 2001; Ruuska et al., 2003). Tais estudos também evidenciaram que a feminilidade pode ser considerada fator de risco para o desenvolvimento de TAs, pois estava associada a altos índices de comportamentos alimentares restritivos e disfuncionais, enquanto que a masculinidade foi considerada fator de proteção. Ao abordarem a questão das normas socioculturais femininas e sua relação com a precipitação de TAs, alguns autores concluíram que as mulheres com esses quadros apresentavam maior propensão a serem femininas, infantis, temperamentais, ambiciosas, desejosas de receberem elogios e de 
possuírem posição social elevada. Em contrapartida, as mulheres sem TAs foram consideradas mais felizes consigo mesmas, confiantes, compreensivas, independentes, autossuficientes e capazes de tomar decisões (Behar, Barrera, \& Michelotti, 2003; Green et al., 2008; Moore \& Keel, 2003).

Nota-se, portanto, que mulheres acometidas por TAs vivenciam dificuldades muito peculiares relacionadas à feminilidade e à sexualidade, dificuldades estas que não são compartilhadas, em sua grande maioria, por mulheres sem as mesmas condições clínicas. No entanto, há lacunas na literatura no que concerne ao trabalho com o significado subjetivo da experiência da sexualidade e da vivência do feminino para mulheres acometidas por TAs. A literatura científica apresenta importantes evidências de que há dificuldades específicas, por parte das mulheres com AN e BN, frente à sexualidade. No entanto, há poucos estudos que abordam as sensações, percepções e sentimentos dessas mulheres a respeito de suas experiências sexuais e, portanto, as evidências empíricas de aspectos subjetivos da vivência da sexualidade e da feminilidade são escassas.

Neste panorama, acredita-se que o presente estudo poderá fornecer esclarecimentos mais pormenorizados a respeito das vivências da sexualidade e da feminilidade no contexto dos TAs, já que as evidências sugerem que esses construtos mantêm íntima relação com o quadro psicopatológico. Como contribuição potencial, considera-se que a ampliação do número de estudos qualificados nessa área poderá proporcionar maiores evidências para a prática clínica, levando a uma compreensão mais abrangente por parte dos profissionais envolvidos na assistência, prevenção e promoção de saúde. 


\section{OBJETIVOS}

Este estudo teve por objetivo investigar o desenvolvimento da sexualidade e da feminilidade em mulheres com TAs, buscando estabelecer relações entre esses aspectos fundamentais da constituição subjetiva e os sintomas que caracterizam o quadro psicopatológico.

\subsection{Objetivos específicos}

1- Investigar como as mulheres com TAs compreendem sua sexualidade;

2- Analisar como pais e mães concebem a sexualidade da filha com TA;

3- Identificar possíveis formas de articulação entre o desenvolvimento da sexualidade, que se dá a partir das vivências relacionais na tríade pai-mãe-filha, e os sintomas de TAs. 


\section{MÉTODO}

\subsection{Delineamento de pesquisa}

O presente estudo foi desenvolvido segundo o enfoque qualitativo de pesquisa, que se propõe a investigar em profundidade um determinado tema e se preocupa com o nível de realidade que não pode ser quantificado, ou seja, trabalha com o universo de significados, motivos, aspirações, expectativas, crenças, valores e atitudes (Minayo, 2008). Nesse sentido, Maykut e Morehouse (1994) definem a pesquisa qualitativa como uma abordagem flexível, que apreende a complexidade e a subjetividade nas narrativas das experiências humanas, incluindo sentimentos, pensamentos e emoções.

Segundo Tong, Sainsbury e Craig (2007), estudos qualitativos utilizam métodos não quantitativos para ampliar o conhecimento e para fornecer novas perspectivas na assistência à saúde. Buscando obter maior rigor metodológico, o presente estudo seguiu as diretrizes propostas pelo COREQ - Consolidate Criteria for Reporting Qualitative Research (Tong, Sainsbury, \& Craig, 2007), que oferece um checklist de 32 itens que devem ser seguidos para garantir o detalhamento e possível reprodução dos passos metodológicos das pesquisas qualitativas, possibilitando que os leitores possam compreender a forma como o estudo foi delineado e conduzido, assim como o modo como os dados foram acessados, codificados e analisados.

Também foi adotado o delineamento de estudo de caso coletivo (Stake, 2000), uma vez que o objetivo deste estudo envolve, de modo geral, a descrição e a caracterização das vivências de mulheres que fazem parte de um grupo específico - os TAs - e seus familiares, configurando a tríade pai-mãe-filha. Segundo Stake (2000), o estudo de casos coletivos não se interessa pela abordagem de um caso em particular, mas de vários casos de forma conjunta, 
visando investigar um fenômeno, população ou condição geral. Esses casos podem ser similares ou diferentes, redundantes ou variados, cada um tendo uma importância particular. O delineamento da pesquisa também pode ser caracterizado como transversal, já que os participantes serão abordados em um momento específico da sua trajetória de vida, ainda que esse momento esteja inserido em um contexto mais amplo (Polit, Becker, \& Hungler, 2004).

\subsection{O método psicanalítico de investigação}

A presente pesquisa foi pautada no referencial teórico da psicanálise enquanto método de investigação. Segundo Silva (2013), ao levar em consideração o inconsciente humano, a pesquisa psicanalítica busca investigar verdades contextuais e muito particulares a cada indivíduo, e não uma verdade absoluta que seja passível generalização. A impossibilidade de previsão do inconsciente não pode exigir uma sistematização completa e exclusiva (Iribarry, 2003). Apesar de se tratar de um campo do saber que muitas vezes é tomado como específico do trabalho clínico terapêutico (Rosa \& Domingues, 2010; Silva, 2013), Freud desenvolveu a psicanálise e por vezes empregou-a fora dos limites do setting terapêutico ao analisar obras de arte, textos, instituições, entre outros. Tais produtos de criação humana por ele analisados podem ser compreendidos como manifestações do inconsciente, carregadas de significados emocionais, conduzidos pelo desejo e direcionados à consciência (Silva, 2013).

A psicanálise traz particularidades que a diferenciam dos métodos concebidos como científicos, geralmente guiados pelo positivismo que caracteriza a maioria das publicações do século XIX (Oliveira \& Tafuri, 2012). Tais particularidades podem ser resumidas em dois pontos essenciais: primeiramente, o fato da pesquisa em psicanálise não ter como objetivo inferir generalizações para uma população específica; em segundo lugar, a estratégia de análise de dados em psicanálise se basear nos significantes e não nos signos (Iribarry, 2003; 
Oliveira \& Tafuri, 2012), ou seja, a análise enfoca os conteúdos latentes do discurso, mais do que os manifestos.

Safra (2013) caracteriza o procedimento analítico como uma “abertura sempre para o mais além” (p. 19). Ao observar, escutar e construir hipóteses ao longo de todo o tratamento, o analista se coloca aberto para perceber fatores novos e inesperados, e para abandonar suposições iniciais quando não se confirmam. Nesse sentido, a psicanálise enquanto modalidade de intervenção terapêutica se aproxima da metodologia da ciência, na qual o conhecimento é produzido pela investigação contínua do fenômeno (Safra, 2013).

Tanto na terapêutica quanto na pesquisa, o trabalho da psicanálise é pautado sobre o fenômeno da transferência (Rosa \& Domingues, 2010; Safra, 2013). Para Bleger (1971), os dados obtidos na pesquisa psicanalítica são provenientes da relação entre pesquisador e pesquisado. Assim como a presença e os questionamentos do pesquisador exercem influência sobre o pesquisado, fazendo-o refletir sobre sua própria história, as falas e comportamentos deste último também exercem efeitos sobre o pesquisador. Berlinck (2002) propõe que a transferência possibilita que o inconsciente emerja, sendo indispensável ao processo de análise e, portanto, ao processo de investigação em psicanálise. Nesse sentido, o pesquisador é colocado em um lugar específico, o de um não-saber a respeito de um enigma.

Para Iribarry (2003), um tipo de pesquisa pela transferência já acontece na própria clínica psicanalítica, uma vez que o analisando realiza uma investigação acerca de suas experiências a partir da transferência para com o analista, ambos atuando como pesquisadores-produtores da verdade contida no inconsciente do analisando. Além disso, o autor também considera que o pesquisador é o primeiro sujeito da pesquisa, pois, ao se movimentar pelas vias de acesso ao inconsciente dos participantes, também se movimenta pelo seu próprio inconsciente e entra em contato com suas próprias questões e sentimentos contratransferencialmente despertados pelo participante, e é a partir desse movimento que o 
pesquisador pode organizar dados e contribuições conceituais. A pesquisa e a escrita em psicanálise carregam a marca do inconsciente do autor, que se faz pela própria atividade de escrita (Oliveira \& Tafuri, 2012).

Silva (2013) ressalta a necessidade de nos atentarmos para o fato de que, nas entrevistas realizadas durante uma pesquisa acadêmica, as informações não chegam até o pesquisador de modo puro e que acabem por expressar a verdade mesma das questões abordadas. Quando o pesquisador se propõe a construir o caso a partir da história que lhe foi contada durante a entrevista, muitas das interpretações das palavras ditas pelo pesquisado envolvem conteúdos significantes do pesquisador, talvez até mais do que do sujeito que fala (Iribarry, 2003; Silva, 2013). O caso é sempre uma construção que envolve o mundo interno do pesquisador, na medida em que as falas e comportamentos do pesquisado seguem uma "travessia de observações e escutas realizadas pelo seu mundo interior, resultando em produção narrativa significada pelas suas experiências e vivências subjetivas” (Silva, 2013, p. 42).

Em suma, pode-se afirmar que todas as manifestações humanas, independente da forma como são apresentadas, são significativas e possuem um sentido coerente com a história de vida do sujeito e o contexto em que vive (Cambuí, 2013). Cada trajetória de vida é sempre particular e única, mas também conta com a participação das pessoas com que o indivíduo interage e das circunstâncias em que ele se insere diariamente. É nesse sentido que o método psicanalítico se faz indispensável: "na medida em que faculta a apreensão das relações existentes entre as dimensões psíquica e social, favorecendo a percepção de que problemáticas inconscientes influenciariam as condutas humanas em situações grupais, organizacionais e institucionais” (Aiello-Vaisberg \& Machado, 2005, p. 29). 


\subsection{COREQ, Domínio I: Grupo de pesquisa e reflexão}

\subsubsection{Caracterização do campo de pesquisa}

Buscando elucidar as características profissionais da pesquisadora e sua relação com os participantes da pesquisa (COREQ, Domínio I: Research team and reflexivity), o serviço de saúde no qual o estudo foi conduzido será descrito a seguir.

A coleta de dados do presente estudo foi empreendida no Grupo de Assistência em Transtornos Alimentares - GRATA. Trata-se de um serviço organizado por uma equipe multidisciplinar de saúde inserida na Clínica de Nutrologia do Hospital das Clínicas da Faculdade de Medicina de Ribeirão Preto (HC-FMRP-USP), no qual a pesquisadora responsável por este estudo atua como psicóloga voluntária desde o ano de 2010, tendo sido estagiária e pesquisadora em nível de Iniciação Científica no período de 2007 a 2009, e em nível de Mestrado de 2010 a 2012. Pelo fato de fazer parte da equipe permanente do serviço e já ter contato prévio com pacientes e familiares, não foi necessária a imersão no campo como etapa preparatória da coleta de dados. Foi concedida autorização formal da instituição para a realização da pesquisa, na pessoa do médico coordenador do GRATA (Anexo II).

O serviço tem como objetivo geral oferecer tratamento a indivíduos acometidos por TAs na cidade de Ribeirão Preto e região. Esse tratamento envolve: grupos de apoio psicológico e de orientação nutricional, tanto aos pacientes quanto aos familiares; acompanhamento nutricional, médico, psiquiátrico e psicológico aos pacientes; psicoterapia aos familiares; reuniões semanais da equipe multidisciplinar para discussão e tomada de decisões a respeito dos casos em seguimento, leitura de artigos científicos e apresentação das pesquisas realizadas dentro do serviço. O quadro de profissionais que compõem o GRATA atualmente engloba: quatro psicólogos, quatro estagiárias do curso de Psicologia, quatro 
nutricionistas, duas estagiárias do curso de Nutrição, dois médicos nutrólogos e uma psiquiatra.

\subsection{COREQ, Domínio II: Detalhamento do estudo}

\subsubsection{Participantes}

A população incluída neste estudo corresponde às pacientes, mães e pais que frequentaram o ambulatório no período da coleta de dados e que preencheram os seguintes critérios de inclusão:

(1) Paciente do sexo feminino, com $\mathrm{AN}$ ou BN, que estivesse sendo atendida no GRATA durante o período delimitado para a coleta de dados (de agosto de 2013 a dezembro de 2014). Os limites etários entre adolescência e vida adulta não são fixos e variam de acordo com fatores constitucionais, psicológicos, sociais, econômicos e culturais. Para fins deste estudo foi considerado o período de 14 a 25 anos como representativo da etapa da adolescência e da jovem adulta. Também configurou um critério de inclusão a disponibilidade dos pais da paciente para participarem voluntariamente da pesquisa, uma vez que as unidades de análise serão as tríades pai-mãe-filha.

(2) Mães e pais: terem filha diagnosticada com AN ou BN e apresentarem frequência de, ao menos, 50\% de participação nos atendimentos voltados à família, considerando os últimos seis meses.

Uma vez que este estudo é proposto dentro da abordagem qualitativa de pesquisa, com ênfase no aprofundamento das descrições coletadas e sua contextualização, um recorte desse universo de participantes torna-se necessário para a garantia da exequibilidade do projeto. Considera-se de suma importância a inclusão da maior diversidade possível de pontos de 
vista, de modo a enriquecer os dados e a alcançar os objetivos propostos. Nesse sentido, os seguintes critérios de seleção também foram respeitados:

(3) Pacientes de diferentes faixas etárias, diagnósticos (AN ou BN) e tempo de seguimento no serviço, desde que respeitado o tempo mínimo de um ano já descrito anteriormente, no item 1;

(4) Mães e pais que também apresentassem faixas etárias diversas, assim como aqueles familiares que, porventura, ocupassem diferentes posições dentro da família e na relação com a paciente (ex. pais adotivos, tios que desempenhassem o papel de pais, entre outros).

Também foram aplicados alguns critérios de exclusão, de forma a se evitar perda de informação em decorrência do status das informantes. Foram eles:

- evidência de prejuízo grave na linguagem ou comunicação;

- déficit sensorial (audição) ou cognitivo, que possa prejudicar a comunicação e a compreensão da tarefa.

Devido ao caráter exploratório desta pesquisa, a coleta de dados foi interrompida ao constatar-se a recorrência (saturação) dos dados, de acordo com Fontanella, Ricas e Turato (2008). Portanto, foram analisados dados de sete tríades edípicas. A Tabela 1, a seguir, expõe os dados antropométricos das participantes (filhas), obtidos a partir de consultas aos prontuários hospitalares. Para impedir a identificação, os nomes próprios foram substituídos por nomes fictícios, escolhidos pelas próprias participantes ao final da entrevista.

Como pode ser observado na Tabela 1, duas pacientes apresentavam diagnóstico de $\mathrm{BN}$, duas apresentavam AN do tipo restritivo e três apresentavam AN do tipo compulsão alimentar purgativa. As idades das participantes variavam entre 14 e 24 anos de idade. O tempo de tratamento variou entre dois e 48 meses. O IMC, na época de cada entrevista, variou entre 14,0 e 22,9 kg/m². Portanto, na época da coleta de dados, as participantes Sofia, Flávia, 
Maria, Gabriela e Manoela encontravam-se eutróficas, apesar de apresentarem outros sintomas alimentares, que serão melhor discutidos na sessão de Resultados. Ana Júlia e Helena apresentavam IMC abaixo do esperado.

Tabela 1. Caracterização das participantes segundo dados antropométricos.

\begin{tabular}{lccccccc}
\hline Participantes & Diagnóstico & Idade & $\begin{array}{c}\text { Peso } \\
\mathbf{( k g})\end{array}$ & $\begin{array}{c}\text { Altura } \\
\mathbf{( m )}\end{array}$ & $\begin{array}{c}\text { IMC } \\
\text { admissão } \\
\mathbf{( k g / \mathbf { m } ^ { 2 } )}\end{array}$ & $\begin{array}{c}\text { IMC } \\
\mathbf{a t u a l} \\
\mathbf{( k g / \mathbf { m } ^ { 2 } )}\end{array}$ & $\begin{array}{c}\text { Tempo de } \\
\text { tratamento } \\
\mathbf{( m e s})\end{array}$ \\
\hline Sofia & BN & 16 & 56 & 1,60 & 23,6 & 21,9 & 2 \\
\hline Ana Júlia & $\begin{array}{c}\text { AN do tipo compulsão } \\
\text { alimentar purgativa }\end{array}$ & 23 & 40,9 & 1,58 & 17,3 & 17,0 & 4 \\
\hline Flávia & BN & 17 & 53,1 & 1,58 & 17,3 & 21,8 & 6 \\
\hline Helena & AN do tipo restritivo & 24 & 34 & 1,56 & 13,8 & 14,0 & 24 \\
\hline Maria & $\begin{array}{c}\text { AN do tipo compulsão } \\
\text { alimentar purgativa }\end{array}$ & 24 & 53,7 & 1,53 & 16,7 & 22,9 & 48 \\
\hline Gabriela & AN do tipo restritivo & 18 & 57,3 & 1,71 & 15,5 & 19,6 & 12 \\
\hline Manoela & AN do tipo restritivo & 14 & 49,5 & 1,61 & 14,1 & 18,9 & 14 \\
\hline
\end{tabular}

Na Tabela 2 são sistematizados os dados sociodemográficos das participantes (filhas), recolhidos no início de cada entrevista. Duas participantes cursavam o Ensino Médio e duas cursavam a universidade. Helena não estudava, uma vez que havia concluído o Ensino Médio e curso técnico em Moda. Gabriela havia concluído o Ensino Médio e interrompido os estudos. Manoela estava cursando o nono ano do Ensino Fundamental. Três participantes trabalhavam: técnica de enfermagem (Ana Júlia, que também fazia curso universitário), vendedora de loja (Helena) e professora particular (Maria). Apenas Sofia estava em um relacionamento afetivo no momento da entrevista. Em relação à crença religiosa, três participantes não tinham religião, duas se declararam católicas e uma era evangélica. 
Tabela 2. Caracterização das participantes segundo dados sociodemográficos.

\begin{tabular}{|c|c|c|c|c|}
\hline Participantes & Escolaridade & Ocupação & $\begin{array}{l}\text { Situação } \\
\text { conjugal }\end{array}$ & Religião \\
\hline Sofia & $\begin{array}{l}\text { Ensino Médio } \\
\text { incompleto }\end{array}$ & Estudante & Namorando & Sem religião \\
\hline Ana Júlia & $\begin{array}{l}\text { Ensino Superior } \\
\text { incompleto }\end{array}$ & $\begin{array}{c}\text { Estudante } \\
\text { universitária } \\
\text { e técnica de } \\
\text { enfermagem }\end{array}$ & Solteira & Católica \\
\hline Flávia & $\begin{array}{l}\text { Ensino Médio } \\
\text { incompleto }\end{array}$ & Estudante & Solteira & Sem religião \\
\hline Helena & $\begin{array}{l}\text { Ensino Médio (curso } \\
\text { técnico) completo }\end{array}$ & Vendedora & Solteira & Sem religião \\
\hline Maria & $\begin{array}{l}\text { Ensino Superior } \\
\text { incompleto }\end{array}$ & $\begin{array}{c}\text { Estudante } \\
\text { universitária } \\
\text { e professora } \\
\text { particular }\end{array}$ & Solteira & Sem religião \\
\hline Gabriela & $\begin{array}{l}\text { Ensino Médio } \\
\text { completo }\end{array}$ & Nenhuma & Solteira & Evangélica \\
\hline Manoela & $\begin{array}{l}\text { Ensino Fundamental } \\
\text { incompleto }\end{array}$ & Estudante & Solteira & Católica \\
\hline
\end{tabular}


Na Tabela 3 encontram-se os dados sociodemográficos relativos aos familiares das pacientes.

Tabela 3. Caracterização dos pais das pacientes segundo idade, escolaridade, profissão/ocupação, situação conjugal, número de filhos e renda familiar aproximadas.

\begin{tabular}{|c|c|c|c|c|c|c|c|c|}
\hline Família & Pacientes & Pais & $\begin{array}{l}\text { Idade } \\
\text { (anos) }\end{array}$ & Escolaridade & $\begin{array}{l}\text { Profissão/ } \\
\text { Ocupação }\end{array}$ & $\begin{array}{l}\text { Situação } \\
\text { conjugal }\end{array}$ & Filhos & $\begin{array}{c}\text { Renda } \\
\text { familiar } \\
\text { aproximada } \\
\text { (R\$) }\end{array}$ \\
\hline \multirow{2}{*}{ Moraes } & \multirow{2}{*}{ Sofia } & Luana & 36 & $\begin{array}{c}\text { Médio } \\
\text { incompleto }\end{array}$ & $\begin{array}{c}\text { Encarregada de } \\
\text { loja/Desempregada }\end{array}$ & Casada & \multirow{2}{*}{ Duas } & \multirow{2}{*}{$2.200,00$} \\
\hline & & Wallace & 41 & $\begin{array}{l}\text { Fundamental } \\
\text { completo }\end{array}$ & $\begin{array}{l}\text { Operador de } \\
\text { empilhadeira }\end{array}$ & Casado & & \\
\hline \multirow[b]{2}{*}{ Batista } & \multirow[b]{2}{*}{ Ana Júlia } & Antônia & 53 & $\begin{array}{l}\text { Fundamental } \\
\text { incompleto }\end{array}$ & $\begin{array}{l}\text { Cozinheira/ } \\
\text { Aposentada }\end{array}$ & Casada & \multirow[b]{2}{*}{ Sete } & \multirow[b]{2}{*}{$4.000,00$} \\
\hline & & Cido & 52 & $\begin{array}{l}\text { Fundamental } \\
\text { completo }\end{array}$ & $\begin{array}{c}\text { Encarregado de } \\
\text { transporte } \\
\text { rodoviário/ } \\
\text { Aposentado }\end{array}$ & Casado & & \\
\hline \multirow{2}{*}{ Paiva } & \multirow{2}{*}{ Flávia } & Márcia & 52 & $\begin{array}{l}\text { Superior } \\
\text { completo }\end{array}$ & $\begin{array}{l}\text { Advogada/ } \\
\text { Aposentada }\end{array}$ & Casada & \multirow{2}{*}{ Três } & \multirow{2}{*}{$10.000,00$} \\
\hline & & José & 52 & $\begin{array}{l}\text { Superior } \\
\text { completo }\end{array}$ & Empresário & Casado & & \\
\hline \multirow{2}{*}{ Garcia } & \multirow{2}{*}{ Helena } & Golita & 44 & $\begin{array}{l}\text { Fundamental } \\
\text { completo }\end{array}$ & Artesã & Casada & \multirow{2}{*}{ Três } & \multirow{2}{*}{$2.200,00$} \\
\hline & & Pedro & 45 & $\begin{array}{l}\text { Fundamental } \\
\text { completo }\end{array}$ & $\begin{array}{c}\text { Área de } \\
\text { ferramentaria }\end{array}$ & Casado & & \\
\hline \multirow{2}{*}{ Teixeira } & \multirow{2}{*}{ Maria } & Maria & 49 & $\begin{array}{l}\text { Médio } \\
\text { completo }\end{array}$ & Carcereira & Casada & \multirow{2}{*}{ Duas } & \multirow{2}{*}{$4.600,00$} \\
\hline & & Lorival & 51 & $\begin{array}{c}\text { Médio } \\
\text { completo }\end{array}$ & Motorista & Casado & & \\
\hline \multirow{2}{*}{ Ribeiro } & \multirow{2}{*}{ Gabriela } & Rebeca & 37 & $\begin{array}{l}\text { Fundamental } \\
\text { incompleto }\end{array}$ & $\begin{array}{l}\text { Ajudante de } \\
\text { cozinha }\end{array}$ & Casada & \multirow{2}{*}{ Três } & \multirow{2}{*}{$2.000,00$} \\
\hline & & Ronaldo & 38 & $\begin{array}{l}\text { Fundamental } \\
\text { completo }\end{array}$ & $\begin{array}{l}\text { Produtor de } \\
\text { vendas }\end{array}$ & Casado & & \\
\hline \multirow{2}{*}{ Freitas } & \multirow{2}{*}{ Manoela } & Carol & 39 & $\begin{array}{l}\text { Superior } \\
\text { técnico }\end{array}$ & Contadora & Casada & \multirow{2}{*}{ Dois } & \multirow{2}{*}{$5.000,00$} \\
\hline & & Dionísio & 43 & $\begin{array}{l}\text { Superior } \\
\text { técnico }\end{array}$ & $\begin{array}{l}\text { Técnico em } \\
\text { Agropecuária }\end{array}$ & Casado & & \\
\hline
\end{tabular}

Todos os filhos residiam com os pais no momento da entrevista. No que concerne à posição na fratria: Sofia era a filha mais nova e tinha uma irmã; Ana Júlia era a sexta filha, 
sendo a primeira após o nascimento de cinco filhos homens, e tinha uma irmã mais nova; Flávia tinha uma irmã gêmea e um irmão mais novo; Helena era a filha mais velha e tinha dois irmãos; Maria era tinha uma irmã mais velha; Gabriela tinha um irmão mais novo e um mais velho; e Manoela tinha um irmão mais novo.

\subsubsection{Instrumentos e materiais}

Para a coleta de dados foram utilizados os seguintes instrumentos:

1- Roteiro de entrevista semiestruturada: A técnica de entrevista semiestruturada foi eleita para ser utilizada na coleta de dados por permitir o aprofundamento em determinado tema de pesquisa, indo além de uma conversa superficial para uma rica discussão a respeito de pensamentos e sentimentos (Maykut \& Morehouse, 1994). Em se tratando de uma relação entre duas pessoas (entrevistador e entrevistado), a entrevista pode ser compreendida como um diálogo dinâmico e mútuo, no qual ocorrem interações e trocas entre as partes, e de onde podem surgir os sentidos e significados para o indivíduo da experiência investigada.

Essa modalidade de coleta de dados implica em compor um roteiro de perguntas elaboradas de forma a atender os objetivos da investigação, adotando uma formulação flexível, de modo que a sucessão das questões e os detalhes deverão ficar por conta do discurso das participantes e da dinâmica da entrevista. A entrevistadora introduz o tema e a pessoa entrevistada tem liberdade para discorrer sobre ele, podendo assim explorar amplamente a questão. As perguntas são respondidas dentro de uma conversação informal, na qual a interferência da entrevistadora deve ser a mínima possível (Minayo, 2008).

Foram elaborados dois roteiros de entrevista semiestruturada, sendo: 
a) Roteiro de entrevista para pacientes (Apêndice I) - Este roteiro foi constituído pelos seguintes temas: (1) Dados sociodemográficos; (2) Informações acerca do TA; (3) Situação emocional da participante; (4) Informações relativas às experiências afetivo-sexuais; (5) Informações relativas à vivência familiar; (6) Desfecho da entrevista.

b) Roteiro de entrevista para mães e pais (Apêndice II) - Tanto para as mães quanto para os pais, o roteiro de entrevista aborda os seguintes temas: (1) Dados sociodemográficos; (2) Informações acerca do TA; (3) Situação emocional da filha; (4) Informações relativas à vivência familiar e às experiências afetivo-sexuais da filha; (5) Desfecho da entrevista.

2- Diário de campo: A pesquisadora tomou notas em uma caderneta de campo, antes, durante e depois da realização das entrevistas, o que favoreceu a análise posterior. Segundo Weber (2009), o diário de campo é um instrumento que o pesquisador se dedica a produzir dia após dia ao longo de toda a experiência investigativa, e que tem por base a realização de observações diretas dos comportamentos de um determinado grupo. Segundo Dalmolin, Lopes e Vasconcellos (2002), nos diários de campos são registradas as atividades desenvolvidas no campo de pesquisa, incluindo descrições, trechos de fala dos participantes, impressões e sentimentos da observadora. Este material é lido e relido durante o processo de pesquisa para que novas interpretações sejam feitas e para que algumas questões sejam aprofundadas. Por meio das anotações no diário de campo, foi possível levantar dados pertinentes ao contexto desta pesquisa - ou seja, o GRATA - e de seus participantes, assim como o movimento da pesquisadora inserida nesse contexto.

3- Critério de Classificação Econômica Brasil/2015 (CCEB/15): No Brasil, desde 1970, têm sido utilizados critérios padronizados de classificação socioeconômica, o que torna o país pioneiro no uso de critérios padronizados para esse fim (Ambrósio, 2010). No entanto, 
a implantação desses critérios seguiu uma história bastante complexa. O Critério Brasil foi criado em 1997, a partir da junção de dois outros critérios: ABA-ANEP e Critério ABIPEME, e passou por seis revisões, resultando na atual, implantada a partir de 1 de janeiro de 2015. Dentre as principais diferenças para o critério utilizado atualmente, estão a substituição da renda declarada por variáveis indicadoras de renda permanente e o uso da Pesquisa de Orçamentos Familiares do IBGE que amplia a abrangência da ferramenta. O novo Critério Brasil identifica de forma mais realista o potencial de consumo dos lares no Brasil (Associação Brasileira de Empresas de Pesquisas [ABEP], 2015). O Critério de Classificação Econômica Brasil 2015 encontra-se no Anexo III.

Para o seu desenvolvimento foram usadas 35 variáveis indicadoras de renda permanente (como educação, condições de moradia, acesso a serviços públicos, posse de bens duráveis a composição familiar, o porte dos municípios e a região onde estão localizados como parâmetros fundamentais para a segmentação e comparação entre os padrões de consumo dos brasileiros.) que permitiram a segmentação dos domicílios brasileiros em estratos e o posterior estudo da relação entre nível socioeconômico e potencial de consumo dos domicílios em relação a 20 categorias de produtos e serviços (dentre elas, alimentação no domicílio e fora de casa, artigos de limpeza, vestuário e saúde e medicamentos). (ABEP, 2015)

Por isso, o CCEB/15 é composto por 12 indicadores discriminantes da renda: número de automóveis, motocicletas, empregados mensalistas, máquinas de lavar roupa, máquinas secadoras de roupas, banheiros, DVD, computadores, micro-ondas, geladeira, freezer (podendo ser aparelho independente ou parte da geladeira duplex), máquinas lavadoras de louça, procedência da água utilizada no domicílio, se a rua em que o domicílio se encontra é asfaltada ou de terra e, por fim, nível educacional do chefe de família (considerado “chefe” a pessoa que contribui com a maior parte da renda do domicílio). A posse de tais itens é pontuada conforme as tabelas que se encontram no Anexo III. 
A nova regra de classificação divide a população brasileira em seis estratos socioeconômicos denominados A, B1, B2, C1, C2 e DE. De acordo com a pontuação de corte dos estratos, o indivíduo é classificado segundo o estrato correspondente aos pontos obtidos. A Tabela 4 indica a divisão em estratos socioeconômicos, a partir da pontuação obtida no CCEB/15, e as respectivas rendas familiares.

Tabela 4. Definição das classes econômicas a partir da distribuição da pontuação no CCEB/15 e renda média domiciliar no ano de 2015.

\begin{tabular}{llc}
\hline Classe & Pontos & $\begin{array}{c}\text { Renda média domiciliar } \\
\text { (Valor Bruto em R\$) }\end{array}$ \\
\hline A1 & 45 a 100 & $20.272,56$ \\
B1 & 38 a 44 & $8.695,88$ \\
B2 & 29 a 37 & $4.427,36$ \\
C1 & 23 a 28 & $2.409,01$ \\
C2 & 17 a 22 & $1.446,24$ \\
D - E & 0 a 16 & 639,78 \\
\hline
\end{tabular}

Fonte: ABEP (2015)

\subsection{COREQ, Domínio III: Análise e resultados}

\subsubsection{Procedimento}

A coleta de dados seguiu as seguintes fases:

FASE 1. Seleção dos participantes: As pacientes do GRATA foram selecionadas para participar da pesquisa a partir dos critérios de inclusão/exclusão previamente mencionados. Após o fornecimento de esclarecimentos acerca do tema da pesquisa, as pacientes selecionadas foram convidadas a participar, e foram informadas de que suas mães e 
pais também receberiam o convite. Mediante o aceite, foi agendado um horário de acordo com a disponibilidade de cada participante, preferencialmente em dia de retorno ambulatorial. O estudo foi explicado detalhadamente e foi pedido que os participantes (ou os responsáveis) assinassem o Termo de Consentimento Livre e Esclarecido - TCLE (Apêndices III, IV e V) para participação na pesquisa, onde constava por escrito os objetivos, o método, a responsabilidade ética da pesquisadora em relação aos dados obtidos e a possibilidade de desistência do entrevistado a qualquer momento do processo de coleta de dados. Não houve respostas negativas em relação ao convite para participar da pesquisa.

Nesta fase foi realizado o pré-teste: Como previsto no Cronograma de Atividades, um pré-teste foi inicialmente realizado para que os instrumentos e o procedimento de coleta de dados fossem testados quanto à clareza, compreensibilidade, ordenação das questões e precisão da linguagem, sendo assim aferidos junto à população-alvo do presente estudo. Foi recrutada para o pré-teste uma paciente e seus familiares que preenchiam os critérios de inclusão preestabelecidos.

A abordagem inicial da participante (paciente) consistiu na apresentação dos objetivos da pesquisa e no convite para que ela colaborasse com a mesma. Mediante anuência da participante, verificou-se sua disponibilidade e agendou-se um horário para que a entrevista fosse realizada no próximo retorno ao serviço ambulatorial. Os pais também foram convidados a participar da pesquisa e, mediante anuência, também foram agendados horários para a realização da entrevista em dias diferentes de retorno ambulatorial.

Ao aplicar-se o protocolo de pesquisa nos participantes selecionados para o pré-teste, notou-se que a entrevista teve duração média de 50 minutos, e que os participantes não demonstraram incômodo com esse tempo nem deram sinais de estarem cansados. Também foi possível notar que os participantes compreenderam todas as questões do roteiro de entrevista. 
Dessa maneira, verificou-se empiricamente a adequação do roteiro de entrevista aos propósitos da pesquisa, por esse motivo os instrumentos e procedimentos de coleta de dados previamente definidos não foram alterados. O material coletado por meio dos relatos dos participantes do pré-teste integrou os resultados da presente pesquisa.

FASE 2. Aplicação dos instrumentos: Todos os participantes convidados a fazer parte da pesquisa aceitaram o convite e formalizaram sua anuência mediante a assinatura do TCLE. Foram entrevistados seguindo os roteiros de entrevista semiestruturada já mencionados anteriormente, e apresentados nos apêndices deste relatório (Apêndices I e II). As entrevistas foram realizadas individualmente em uma sala reservada da instituição hospitalar, com condições apropriadas de conforto e privacidade. Em casos específicos - e desde que solicitado por algum dos participantes - as entrevistas poderiam ser agendadas fora das dependências do hospital, de acordo com a disponibilidade dos voluntários.

As entrevistas foram audiogravadas na íntegra por meio de um gravador MP3, mediante anuência dos participantes, para assegurar maior fidedignidade dos dados colhidos e preservar a objetividade do estudo. Nos registros em áudio ficam registradas a linguagem falada com seus aspectos não-verbais, como a entonação da voz, pausas, hesitações e intensidade das verbalizações, o que auxilia a análise dos dados. Após a realização das entrevistas com as filhas, foi aplicado o CCEB/2015.

Concomitantemente à aplicação da entrevista, foram elaboradas pela pesquisadora as anotações do diário de campo. Explicitou-se para os participantes a importância da utilização desse recurso para a caracterização do campo de pesquisa, enriquecendo as descrições com o detalhamento dos comportamentos observados e das impressões da pesquisadora. 
FASE 3. Análise dos dados: A análise seguiu os seguintes passos: as entrevistas audiogravadas foram transcritas na íntegra e literalmente, respeitando a sequência e a forma como foram expressas as falas. O material coligido nas entrevistas, juntamente com a transcrição do diário de campo e dos resultados do CCEB/2015, constituiu o corpus da pesquisa a ser analisado e interpretado. Esse material foi submetido à Análise Temática (Braun \& Clarke, 2006), procedimento que visa a ultrapassar o alcance descritivo da mensagem, excedendo os conteúdos manifestos até alcançar os conteúdos latentes. Os dados foram organizados em categorias temáticas, levando-se em conta a variedade e regularidade das respostas e os padrões convergentes de conteúdo dos relatos, assim como a triangulação dos dados provenientes das entrevistas dos pais, mães e filhas. A triangulação (Stake, 2000) implica em um processo de utilização de múltiplas percepções - em geral, a partir de diversas fontes de dados - para esclarecer significados e interpretações, e também para identificar diferentes formas de percepção de um mesmo fenômeno.

Segundo Braun e Clarke (2006), a análise temática deve ser considerada um método indispensável na realização de pesquisas qualitativas, que envolvem a análise de dados bastante diversos, complexos e subjetivos. Trata-se de um método para identificar, analisar e reportar padrões (temas) encontrados no corpus de pesquisa. Busca-se organizar e descrever os conjuntos de dados (entrevistas) de maneira detalhada, e interpretá-los de acordo com os objetivos da pesquisa.

As autoras mencionadas enfatizam o papel ativo do pesquisador na identificação, descrição e interpretação dos dados obtidos. Não se trata de "temas que emergem dos dados” e aos quais o pesquisador apenas “dá voz”, mas sim de um esforço contínuo por parte do pesquisador para observar e refletir sobre os dados coletados e desenvolver ligações com a abordagem teórico-metodológica adotada. Nesse sentido, é importante que sejam tomadas 
decisões a respeito da abordagem adotada, que esta seja coerente com o objeto de pesquisa e com o que o pesquisador deseja saber.

O processo de realização da análise temática é iniciado quando o pesquisador começa a procurar e perceber padrões convergentes de significados e questões de potencial interesse nos dados, tanto durante quanto após a finalização da coleta de dados. O fim do processo envolve reportar o conteúdo e significado dos temas. No entanto, esse processo não é linear: o pesquisador "vai e volta" inúmeras vezes ao conjunto inteiro de dados, aos trechos de entrevistas analisadas e à interpretação dos dados que está sendo produzida (Braun \& Clarke, 2006). Os passos metodológicos envolvidos no processo de análise temática proposto por Braun e Clarke (2006) e adotados no presente estudo serão descritos a seguir:

(1) Familiarização com os dados: consiste na imersão do pesquisador nos dados, até o ponto de se perceber familiarizado com a profundidade e extensão dos conteúdos. Envolve leituras repetitivas e ativas, buscando significados e padrões.

(2) Criação de elementos de análise iniciais: desenvolvimento de uma lista inicial de ideias sobre os principais elementos de análise que constam nos dados e que são relevantes para a pesquisa em questão. Os elementos iniciais servem para identificar características dos dados (conteúdos semânticos ou latentes) que o pesquisador considera relevantes, e que sejam referentes a segmentos "brutos" dos dados, mas que podem ser avaliados de maneira significativa para a compreensão do objeto de pesquisa.

(3) Procurando temas: quando todo o conjunto de dados tiver sido codificado e coligido, parte-se para a criação de temas maiores, que englobam os elementos de análise iniciais e os une de forma combinada, a partir da convergência temática. Para ilustrar os temas desenvolvidos, é possível utilizar-se de diagramas, mind maps, tabelas, entre outros. 
(4) Revisando temas: esta fase se inicia quando o pesquisador houver desenvolvido um conjunto de potenciais temas, e envolve o refinamento dos mesmos. Os temas são reorganizados: combinados, divididos em dois ou mais temas ou mesmo excluídos.

(5) Definindo e nomeando temas: quando o pesquisador tiver um mapa temático satisfatório, deve-se definir e refinar novamente os temas a serem analisados. Por "definir e refinar”, as autoras enfatizam a importância de identificar a essência do que se trata cada tema, e determinar qual aspecto dos dados cada tema aborda.

(6) Produzindo o manuscrito: esta fase se inicia no momento em que o pesquisador tem um conjunto definitivo de temas, e envolve a análise final e escrita do manuscrito. Nesse momento, é importante que a análise ofereça uma visão concisa, coerente, lógica, não repetitiva e relevante a respeito dos dados obtidos. A escrita final deve fornecer evidências suficientes dos temas oriundos dos dados, por exemplo, trechos de entrevistas que demonstrem a prevalência do tema em questão.

Os dados obtidos foram divididos em dois eixos, a saber:

\section{a) Eixo I - Análise vertical dos dados}

Neste momento da análise dos dados, foram descritos os materiais produzidos por cada tríade filha-mãe-pai, considerados neste estudo como unidades familiares, para que se procedesse ao reconhecimento das particularidades de cada uma. As unidades de análise vertical foram as tríades pai-mãe-filha, identificadas por um sobrenome familiar fictício, por exemplo, Família Moraes. A análise foi pautada por um fio condutor, que buscava elucidar a forma como se desenvolveu a feminilidade e sexualidade da filha dentro de cada unidade familiar, assim como as relações afetivo-sexuais e o modo como a experiência dessas relações podem afetar e ser afetadas pelo TA.

É importante destacar também que a análise favoreceu a identificação da percepção que mães e pais tinham da sexualidade da filha, uma vez que essa compreensão pode ter 
desdobramentos emocionais cruciais na expressão dos sintomas alimentares, mantendo estreita relação com o quadro psicopatológico. Esse tipo de análise se assenta nas associações dos entrevistados diante das questões propostas. Consiste essencialmente em colocar em evidência a significação das palavras, ações e produções imaginárias de cada participante, que emergiram no material ideativo produzido na relação estabelecida com a entrevistadora. Os temas retirados dos relatos dos participantes nas entrevistas foram complementados pelas descrições e impressões anotadas no diário de campo.

Neste eixo, também serão apresentados os dados de classificação socioeconômica, oriundos do CCEB/2015.

\section{b) Eixo II - Análise horizontal dos dados}

Esta última etapa da análise dos dados é dedicada à interpretação das convergências e divergências encontradas nos relatos dos participantes, sendo que os resultados serão apresentados e discutidos sob a ótica de cada conjunto de participantes, a saber: mães, pais e filhas, e as duplas mãe-filha, pai-filha e o casal parental. Os pontos em concordância e que estivessem relacionados aos objetivos do estudo foram considerados para a discussão, permitindo descrever em detalhes os conteúdos e sentidos recorrentes que surgiram, buscando-se com esse enfoque colocar em relevo a densidade e a riqueza discursiva do material coligido.

\subsection{Considerações éticas}

O presente estudo foi aprovado pelo Comitê de Ética em Pesquisa da Faculdade de Filosofia, Ciências e Letras de Ribeirão Preto da Universidade de São Paulo (CEP-FFCLRPUSP), obtendo aprovação sob processo CAAE n ${ }^{\circ}$ 11955112.4.0000.5407 (Anexo IV). A coleta e análise dos dados estão sendo conduzidas de acordo com a resolução n ${ }^{\text {196/96 do }}$ 
Conselho Nacional de Saúde, que regulamenta a "pesquisa envolvendo seres humanos" (Brasil, 2012). A participação dos pacientes e familiares no estudo foi voluntária, de modo que, antes do início da coleta dos dados, como já mencionado anteriormente, todos os sujeitos formalizam sua anuência mediante a assinatura do termo do TCLE (Apêndices III e V). Para os participantes menores de 18 anos foi solicitada aos pais ou responsáveis a autorização de sua participação por meio de sua anuência expressa na assinatura de um TCLE específico para tais situações (Apêndice IV).

Além disso, a coleta dos dados foi efetuada em conformidade com a disponibilidade e motivação dos participantes. Não foram utilizadas técnicas de persuasão de qualquer espécie no sentido de tentar convencer quem não quiser participar a mudar de ideia e todos os participantes podiam desistir de participar do estudo a qualquer momento, sem prejuízos para o seu atendimento na instituição. Esses cuidados evidenciam que o respeito aos voluntários e à própria instituição constituíram um dos princípios básicos que nortearam este estudo. 


\section{RESULTADOS E DISCUSSÃO}

A apresentação dos resultados e da discussão será feita, primeiramente, pelo Eixo I (item 4.1), que inclui a análise vertical de cada tríade e conta com a construção de quatro elementos de análise, cujo objetivo foi facilitar a leitura e compreensão de cada caso. Os elementos de análise são: 1. O transtorno alimentar; 2. A relação familiar; 3. O despertar da feminilidade; 4. Relacionamentos afetivos e vida sexual. Além disso, antes da apresentação de cada tríade, será exposto um mapa de associação de ideias que inclui as categorias temáticas presentes na análise de cada tríade, e que se serão sintetizadas e discutidas no Eixo II. Dessa forma, no Eixo I, as tríades pai-mãe-filha constituíram as unidades de análise.

Posteriormente (item 4.2), será apresentado o Eixo II, que engloba categorias temáticas derivadas da síntese integrativa dos elementos de análise que compuseram a descrição das tríades, buscando elucidar os aspectos convergentes e divergentes, de um lado das vivências dos familiares e, do outro, das filhas. 


\subsection{Eixo I - Análise vertical dos dados: A singularidade da experiência em família}

\subsubsection{Família Moraes}

Sofia, a filha: “Não, eu não sinto nada, na verdade."

Luana, a mãe: "Se ela também me largasse pra lá, eu acho que eu não ia dar conta"

Wallace, o pai: "Depois que um elo de corrente quebra, não adianta tentar soldar"

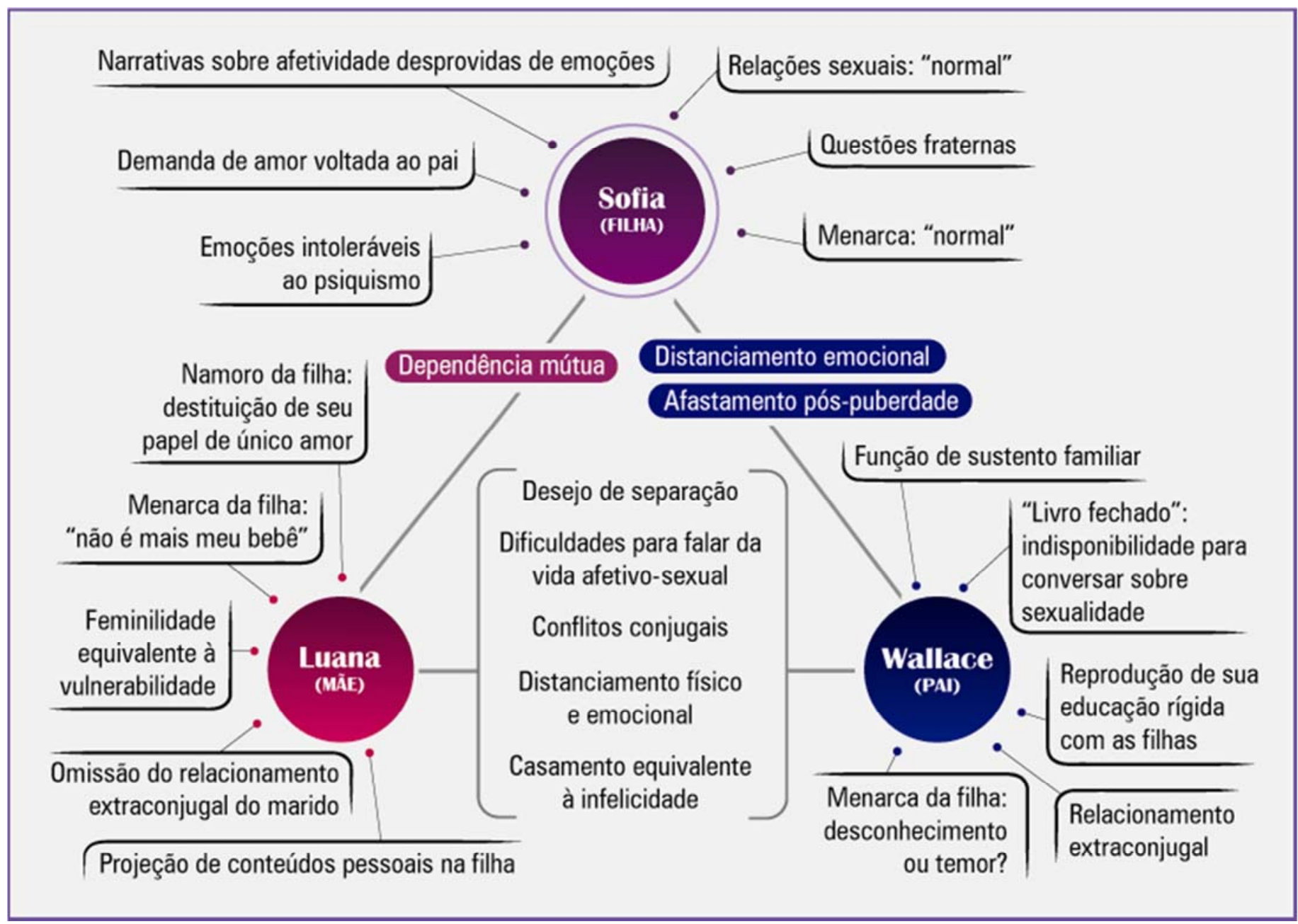

Figura 1. Mapa de associação de ideias da família Moraes. 
Sofia iniciou o tratamento no GRATA em abril de 2013, com 16 anos de idade, devido a episódios frequentes de compulsão alimentar, seguidos de vômitos. Pesava na época 60 kg, tinha $1,60 \mathrm{~m}$ de altura e IMC $=23,6 \mathrm{~km} / \mathrm{m}^{2}$, que caracteriza eutrofia, ou seja, o peso estava dentro da normalidade para sua idade e altura. Os episódios de compulsão alimentar haviam se iniciado havia três anos, após Sofia ter sido reprovada em um concurso para modelo, no qual havia cerca de 30 participantes e ela deveria ter sido selecionada entre as primeiras 15 colocadas. A paciente relatava que se sentia feia e gorda, e admitia que gostaria de pesar 50 kg.

O diagnóstico atribuído pela equipe de saúde foi de BN, com traços de transtorno de personalidade borderline. Segundo o DSM-V (American Psychatric Association, 2013), esse transtorno, de forma geral, indica padrões de impulsividade e instabilidade emocional que se refletem nos relacionamentos interpessoais, na autoimagem e nos afetos. Também se manifestam graves dificuldades para lidar com o abandono - real ou imaginário -, já que a separação ou a percepção de rejeição pode acarretar sentimento de raiva inadequada e ações impulsivas, tais como comportamento suicida ou de automutilação. Além de instabilidade do humor, descontrole emocional e explosões de raiva, os pacientes podem apresentar tristeza, ciúmes intenso, apego afetivo exacerbado, teimosia e insatisfação pessoal (Rosa \& Santos, 2011). Quando esses comportamentos e sentimentos se apresentam de forma recorrente, intensa e persistente, produzem um padrão existencial marcado por dificuldades de adaptação ao ambiente social e suscetibilidade ao transbordamento afetivo. Pacientes borderlines tendem a lidar mal com qualquer tipo de adversidade, especialmente com aquelas que envolvem rejeição, desaprovação ou abandono. Quando se deparam com essas situações, costumam vivenciar uma reação de estresse intensa, com consequências imprevisíveis (Leonidas \& Santos, 2013). 
A entrevista com Sofia foi realizada dois meses após o início do tratamento, portanto, os dados antropométricos não haviam sofrido mudanças significativas naquele momento: 56 $\mathrm{kg}, 1,60 \mathrm{~m}$ de altura e IMC $=21,9 \mathrm{~kg} / \mathrm{m}^{2}$. Durante a entrevista, a participante falou pouco e manteve um tom de voz muito baixo, dificultando a compreensão. Olhava sempre para as mãos, que mantinha entrelaçadas no colo, e às vezes raspava o esmalte preto das unhas, que já estava pela metade. Evitava o contato visual com a pesquisadora e sorria pouco, sempre de forma "forçada". Vestia uma blusa cinza bastante colada ao corpo, calça jeans preta, sapatilhas e uma tiara na cabeça.

A renda da família Moraes, segundo relato do pai, era de aproximadamente 2.200,00 reais. No entanto, o resultado do CCEB/2015 indicou que a família se encaixa no estrato socioeconômico B2, que inclui rendas familiares de aproximadamente 4.427,36 reais. Trata-se de um estrato socioeconomicamente baixo, considerando-se que a família é composta por quatro membros adultos e uma criança.

\section{O transtorno alimentar}

Sofia relatou, inicialmente, que suas dificuldades com a alimentação envolviam episódios de perda do controle, nos quais comia exageradamente e fazia uso de métodos purgativos para compensar o ganho calórico, tais como vômitos e uso de laxantes. Atribuiu o início dos sintomas a um concurso do tipo "garota estudantil”, no qual 30 garotas participaram do desfile, mas apenas 15 foram selecionadas para a final, e Sofia não obteve sucesso nessa competição.

No entanto, ao longo da entrevista, evidenciou-se que a referida perda do controle que era expressa, em primeiro momento, na alimentação excessiva - também emergia em outras situações de sua vida, tais como no ato de "descontar a raiva" nos familiares e no namorado. Os relatos acerca desse sentimento (raiva) foram marcados por indiferença. A 
participante disse desconhecer suas raízes, assim como da BN. Sofia referiu como sente uma necessidade incontrolável de comer sem parar, o que remete à busca do gozo impossível descrito por Brusset (2003). Segundo este autor, os episódios compulsivos envolvem vivências extremamente angustiantes e que causam alienação, fazendo com que o sujeito se sinta obrigado a realizar condutas que o afastam de si mesmo, e sobre as quais não consegue exercer controle. Trata-se de uma impossibilidade das defesas psíquicas conterem afetos destrutivos, fazendo com que as emoções se transformem em atos destrutivos (McDougall, 1991).

Durante a entrevista, Sofia confidenciou que costumava fazer cortes em sua pele. As escarificações também podem ser considerados exemplos das emoções angustiantes, que não podem ser nomeadas e pensadas, apenas transpostas para o corpo físico e vividas sensorialmente, “por redução dos afetos à sensação” (Couvreur, 2003, p. 44).

Porque a maioria das vezes que eu me corto é por causa do meu pai, mas nem sempre é uma briga feia. Às vezes só uma coisinha que ele fala já me machuca, sabe? (Entrevista com Sofia)

Quando questionada a respeito dessas “coisinhas” que o pai fala e que a machucam, Sofia não consegue descrevê-las, indicando a impossibilidade de conter as emoções negativas despertadas pela fala paterna. Nesse momento, o direcionamento da angústia para o corpo, em forma de pequenos cortes desferidos na pele, surge como única possibilidade de alívio para a tensão acumulada.

Para a mãe (Luana), a filha sempre apresentou insatisfação com o corpo, desde quando era criança e os primos chamavam-na de gorda. Considera que era o meio que os meninos encontravam de deixa-la "agitada”, pois sabiam que ela se irritava com tais comentários. No entanto, a atitude de "parar de comer" e "só tomar água” começou havia quatro anos, devido ao fato de não ter sido selecionada em um concurso de garota estudantil. Luana relatou que 
Sofia não gosta de “ouvir não": é como se o "não” fosse “o fim” para a filha, que "não aceitava perder" de jeito algum.

No entanto, o pai apresentou uma visão diferente no que concerne ao despertar do TA: acredita que sua própria rigidez na educação da filha pode ter influenciado o início dos sintomas.

Tipo, de primeiro, eu falava pra ela que até os... até os dezoito ano ela não ia namorar. Não deixava ela sair nem nada, tudo essas coiserada porque, tipo assim, eu sou das antigas mesmo. [...] Aí a partir do momento que ela começou isso, eu fiquei pensando que era por causa que eu não deixava ela namorar, essas coiserada tudo. Liberei ela pra namorar, tudo, mas continua, tudo... a mesma... [...] Até pensei que era por certas situações que aconteciam entre mim, minha esposa, entendeu? (Entrevista com Wallace)

Além da rigidez com que admitia criar a filha, Wallace também considera que os conflitos que mantinha com a esposa também podiam estar relacionados com o TA da filha. Tais conflitos serão melhor explicitados na sequência.

\section{As relações familiares}

Durante a entrevista, Wallace confidenciou que manteve um relacionamento extraconjugal por seis anos, e que é motivo de conflitos na família até os dias atuais. A esposa descobriu essa relação e, desde então, Wallace considera que ele e a esposa nunca foram felizes, pois “depois que um elo de corrente se quebra, não adianta tentar soldar, que nunca é a mesma coisa”. O participante repetiu várias vezes um discurso a respeito de confiança. E manifestou a culpa que sente por ter quebrado a confiança da esposa, revelando sua desesperança de reconquistá-la um dia.

Também houve momentos na entrevista em que Wallace explicitou o desejo de ir embora de casa, abandonar a família e se afastar dos problemas. Tais confidências indicam a dupla face do sentimento de culpa: por um lado, a culpa por ter "quebrado o elo de 
confiança" da esposa, e por outro, a culpa inconsciente pelo desejo de não mais fazer parte daquele casamento e daquela família, uma vez que "só vive dentro de casa por causa da netinha”. Além disso, Wallace também contou que sempre teve problemas com sua esposa, desde o início do casamento e antes mesmo de iniciar o relacionamento extraconjugal: por diversas vezes relatou que "nunca conseguiu fazer a esposa feliz", e se referiu ao casamento como "besteira", mostrando-se profundamente frustrado e insatisfeito com a relação conjugal.

Quando a gente, a gente pensa que tá amando ou ama uma pessoa, a pessoa propõe e a outra faz muita besteira. Entendeu? Porque ela não deveria ter... Ter largado os estudos, por mais que ela gostasse de mim, por minha causa, você está entendendo? Mas quando a gente... Você sabe, quando a gente tá gostando, ou pensa que está gostando, a gente faz muita besteira na vida. (Entrevista com Wallace)

Wallace sempre insistiu para que as filhas se formassem e tivessem um emprego, “para não depender de homem nenhum”. Parece que há uma relação inconsciente entre sua infelicidade no casamento e o que espera da filha: ao desejar que a filha seja independente, o relato parece indicar o desejo de que a filha seja diferente da mãe, essa mãe que “desistiu de tudo", que abdicou de si mesma pelo marido, e que foi conivente com a "besteira" de se casar. Até mesmo quando a filha mais velha engravidou na adolescência, Wallace não insistiu para que ela se casasse, mesmo que carregasse o estigma de “mãe solteira”.

Não sei se amava ou pensava que amava ela, então eu falei pra ela "Ó, tipo assim, eu estou em outra cidade, é... Você vai ter que escolher entre o estudo e a mim, porque... A minha pessoa, porque... Eu não vou estar confiando em você.” Aí beleza, então ela desistiu de tudo para estar comigo. Então acho que é por isso que hoje ainda esse casamento persiste, porque eu penso no que ela fez lá atrás, né, porque... Não sei se existe amor mais... Da minha parte. (Entrevista com Wallace)

Os conflitos conjugais parecem se misturar com os conflitos vivenciados na relação dos pais com as filhas, pois, segundo o relato de Wallace, a esposa impede que ele exerça a função paterna na educação das filhas. Ao tentar puni-las por algo que fizeram de errado (por exemplo, quando elas saem de casa escondidas para ir ao carnaval, apesar do pai ter dito que 
não poderiam ir), a esposa intervém dizendo que Wallace “não tem moral para bater nas filhas”, se referindo ao fato de que ele também erra. As filhas, por sua vez, repetem o discurso da mãe: "Então me fala se você tem moral de me corrigir, você que tem um caso com fulana". Pelo discurso de Wallace e pela emoção que expressou ao chorar durante a entrevista, nota-se que o participante sente-se desmoralizado em sua função de autoridade, sofre intensa angústia pelo desejo frustrado de regular as condutas e interditar a vida das filhas, mas sente-se impotente frente ao sentimento de culpa por ter "quebrado o elo de confiança" da esposa e também frente aos ataques das três mulheres, quando tenta se impor dentro de casa.

Para Wallace, o relacionamento extraconjugal parecia denotar uma espécie de punição sádica aplicada contra a esposa, de quem não esconde sentir muita raiva pelas brigas reiteradas e insatisfações acumuladas ao longo de décadas. Ambos os cônjuges pareciam culpar-se um ao outro pela "besteira" do casamento, que condensava a infelicidade e o inferno conjugal que estavam vivenciando havia 26 anos. Por sua vez, a esposa parecia se unir cada vez mais às filhas, especialmente à Sofia, fechando o cerco e mantendo o marido de fora da relação.

Ah, sei lá, eu tinha... Que nem eu te falo, é... Tinha raiva, tudo, do... das brigas... Quando nós tinha nossas brigas... ela usava nossas filhas, então minha raiva aumentava. Então... era um modo dela se vingar de mim era usando nossas filhas... $e$ eu, por minha vez, num... num... num largava pra... pra ter, sei lá... num sei... Só sei que, é... é besteira, foi besteira em cima de besteira, então... é complicado. (Entrevista com Wallace)

Wallace nunca havia comparecido ao tratamento de Sofia, apesar das insistências por parte da equipe multidisciplinar. Por esse motivo, precisei ligar na casa da participante para convidar o pai a participar da pesquisa e também do grupo de familiares, aos quais ele aceitou prontamente. (Diário de campo, entrevista com Wallace)

Luana não mencionou o relacionamento extraconjugal do marido durante a entrevista.

[...] Se emocionou ao falar da relação com o marido e da falta de apoio relacionada a ele, mas percebi que a participante não dava muita continuidade aos meus questionamentos acerca do relacionamento conjugal. Percebi que havia muitos conflitos entre marido e mulher, mas Luana não se sentiu confortável para falar sobre 
os mesmos, apesar de algumas insistências de minha parte. (Diário de campo, entrevista com Luana)

Quando questionada a respeito do casamento, respondeu de forma monossilábica, relatando apenas que não mantinha relação sexual com o marido e que evitava conversar com ela para não discutir. No entanto, referiu-se várias vezes à falta de apoio e ao sentimento de desamparo que sentia por não poder dividir com o marido as responsabilidades dos cuidados de saúde com Sofia.

Ah, às vezes eu nem sei ainda, sabe quando você ainda não descobriu qual que é o meu papel? Porque, sabe, eu tento fazer o máximo, quando eu vejo alguma reportagem, assim, eu vou assistir, pra ver se eu tô fazendo certo, se meu papel é esse... Porque fica difícil, se pelo menos meu marido ficasse do meu lado, era mais fácil, eu acho que eu ia dividir. Ah, tem coisa que eu fico só pra mim, sabe, aí às vezes você só chora, vai fazer o que? (Entrevista com Luana)

Assim como Wallace, Luana também se referiu ao casamento como um erro do qual ela se arrepende. Relatou ter medo de que acontecesse a mesma coisa com a filha, e por isso procurava conversar sempre com ela, dizendo que ela era "muito nova para namorar". A relação de Luana com sua própria mãe emergiu nesse momento como algo central na infelicidade que refere sentir desde o casamento: Luana confidenciou que tinha medo de que, se não se casasse com Wallace, ficaria sozinha ("pra titia”), e gostaria que a mãe tivesse percebido essa insegurança e conversado mais com ela, oferecendo-lhe apoio na importante decisão entre casar ou não casar, “fazer a loucura” ou não. Evidencia-se aqui a deficiência do holding materno (Winnicott, 1960), ou seja, uma possível lacuna vivenciada na relação com a mãe. Luana parece se ressentir da ausência de uma figura materna suficientemente boa, que pudesse sustentar um ambiente emocionalmente seguro e não intrusivo, o que reforça a importância que a psicanálise atribui a uma mãe-ambiente que possa conter e sustentar as angústias da filha. Quando há disponibilidade do holding, os sentimentos agonizantes podem ser transformados em experiências positivas (Januário \& Tafuri, 2011) e certas angústias 
impensáveis podem adquirir sentido. Se Luana sente que não teve essa “sustentação” básica por parte da mãe, fica a questão: como “sustentar" emocionalmente a própria filha?

A ideia de separar-se do marido foi mencionada por Luana algumas vezes, em função de sentir-se sozinha e sem apoio. Relatou que “não consegue ver o casamento mais”, e que só mantém as aparências no relacionamento com o marido por causa das filhas. Sofia parece ocupar o lugar de parceira da mãe: “[...] a Sofia é mais apegada, ela acaba se preocupando mais comigo, entendeu? Senão... Se ela também me largasse pra lá, eu acho que eu não ia dar conta não".

Apesar do discurso de Luana indicar a necessidade de Sofia estar sempre próxima à mãe, evidencia-se também uma contrapartida da demanda de proximidade da própria Luana, que também se “apegou” à filha e passou a fazer tudo o que ela gosta, desde comprar sapatos pela internet até ir à "balada". O relacionamento mãe-filha se mostra totalmente indiferenciado, caracterizando um vínculo fusional e simbiótico. O gozo auferido na manutenção da proximidade com a filha e na percepção de ser única e exclusiva em sua vida se expressa em alguns trechos da entrevista, como nos relatos a seguir:

[...] E sempre as duas [filhas], uma tem ciúme da outra, sempre, desde pequenas, então é uma coisa que é delas mesmo, o ciúme. E ela sempre falou, a Sofia: "Mãe, se você engravidar de novo, eu vou embora de casa", sempre falou isso, que ela não queria mais irmão. Aí veio a sobrinha, ela tem ciúme, mas ela cuida, tá sempre brincando as duas, mas ela tem ciúme também. Ela é muito ciumenta, a Sofia... As duas têm muito ciúme de mim. [...] Sair pra gastar, a gente sai um pouco... Tudo que ela gosta eu procuro sair com ela, até balada, como eu falei, eu já cheguei a ir com ela. [...] É, então tudo que ela gosta de fazer, assim, eu gosto de participar. [...] Mesmo não gostando, mas eu... Sabe, tenho um prazer de ir com ela. (Entrevista com Luana)

[...] Usava uma roupa discreta: blusa preta, calça jeans, sapatilha do tipo Melissa de cor vermelha escura e bolsa de cor mostarda, que manteve no colo durante toda a entrevista. Ao reparar na sapatilha, me lembrei que no grupo de familiares daquele dia - que havia sido realizado pouco antes da entrevista - Luana relatou que a forma mais efetiva de deixar Sofia feliz era comprando sandálias "Melissa"; disse também que as duas são "loucas por compras", e que faz tudo com a filha, "até ir na balada", mesmo não gostando. Disse que não tem nada que gosta de fazer, só cuidar da neta e da família, e por isso não se importava de acompanhar a filha aos lugares. (Diário de campo, entrevista com Luana) 
Durante a coleta de dados, a dificuldade de separação entre mãe e filha ficou rapidamente explicitada, como pode ser observado no excerto extraído do diário de campo da entrevista com Sofia:

[...] Pedi que a mãe aguardasse no corredor de espera do ambulatório enquanto a entrevista fosse realizada; mãe e filha se entreolharam, ficaram alguns segundos em silêncio, e a mãe disse para Sofia: "Depois você me encontra, ou você quer que eu venha te buscar?”. A filha não respondeu de imediato, mas logo em seguida disse que encontraria a mãe no corredor. Expliquei que logo após a entrevista seria iniciado o grupo de pacientes na mesma sala, e que Sofia poderia ficar direto para o grupo, enquanto a mãe iria para o grupo de familiares. Ambas se entreolharam novamente e permaneceram em silêncio, sorrindo de forma incômoda. (Diário de campo, entrevista com Sofia)

Segundo Halberstadt-Freud (2001), as semelhanças entre mãe e filha e o fato de compartilharem do mesmo gênero facilita a identificação mútua e o desenvolvimento de uma relação fusional, sem intervalo, sem separação. A referida autora propõe que mães narcisicamente insatisfeitas tomam as filhas como extensão de si mesmas, sendo que estas têm a responsabilidade - transmitida inconscientemente - de "realizar os projetos narcísicos da mãe” (Ribeiro, 2011, p. 61). Nesses casos, Halberstadt-Freud afirma que a independência e a sexualidade da filha permanecem impossibilitadas de existir e, quando insistem em existir, despertam extrema dor psíquica. Tomando por base esses pressupostos, pode-se pensar na contrapartida da mãe, que também tem a sua independência e sexualidade comprometidas, sem espaço para emergirem de forma plena e satisfatória. Ao viver a vida da filha - fazer tudo o que ela gosta, sair com ela até na balada, entre outros comportamentos inadequados - a mãe nega a sua própria existência enquanto mulher, além de seus desejos em relação ao parceiro, abdicando de toda forma de prazer na vida conjugal. Mãe e filha permanecem aprisionadas em uma relação onde só há espaço para as duas, que se fundem a ponto de se tornarem uma entidade psíquica única. 
Sofia descreveu o pai como uma pessoa afetivamente distante, que não conversa muito e que não se manifesta quando a filha desconta sua raiva, seja nos familiares ou no próprio corpo, por meio dos cortes na própria pele. O discurso da participante parecia elucidar um pai que tinha olhos para várias mulheres (esposa, filha mais velha, amante, e até mesmo para a neta), mas nunca para Sofia.

Uma vez eu escutei ela [a mãe] conversando com meu pai. [...] Foi a primeira vez que ela viu meu braço, que ela tinha descobrido que eu me cortava, ela foi conversar com meu pai, ela achou que eu tava dormindo... Ela falou que eu tava assim por causa dele e que era pra ele tentar conversar mais comigo, que ele sempre deu mais atenção pra T. do que pra mim, que desde quando a gente era criança ele falava que gostava mais da T. do que de mim. (Entrevista com Sofia)

Como já mencionado anteriormente, os cortes na pele parecem estar relacionados com sentimentos agonizantes "por causa do pai”, uma vez que "só uma coisinha que ele fala já “machuca". Trata-se de sentimentos que a participante não consegue nomear, seja para a pesquisadora durante a entrevista, seja para si mesma. Por vezes Sofia relatou que "não sente nada", inclusive quando contou sobre o desejo do pai de ter um filho do sexo masculino, apesar de já ter mencionado o medo de decepcioná-lo. Esse discurso permeado pelo desejo de “sentir nada" - encenado dramaticamente na mortificação corporal - é condizente com o que foi percebido pela pesquisadora e descrito no diário de campo: a participante manteve o olhar voltado para as próprias mãos, a voz baixa e transpirando insegurança, a manutenção da mesma postura ereta e empertigada durante toda a entrevista. Sofia mostrou-se lacônica. Falou muito pouco, como se não houvesse material simbólico para transmitir suas emoções ao outro. A sensação da pesquisadora no contato com Sofia foi de um "nada”, de alguém que estava ali, mas lutava por não estar, e que às custas de intensa dor psíquica liberava algumas poucas palavras, em conta-gotas.

O “nada” percebido pela pesquisadora e o “não sentir” trazido pela participante na entrevista remete à ideia de pulverização da vivência afetiva (McDougall, 1991), que implica 
que a experiência de uma emoção intensa não pode ser reconhecida por alguns indivíduos e, portanto, não pode ser psiquicamente elaborada. Trata-se da inexistência da condição de continência dos sentimentos agonizantes, condição esta que é criada na base da experiência do bebê com a mãe, uma vez que o bebê precisa de outra mente que tenha condição para conter seus impulsos. Acredita-se que a impossibilidade de continência está intimamente relacionada com os vômitos e os cortes na pele, que caracterizam formas de vivenciar sensorialmente a dor que não pôde ser pensada.

No que concerne à relação com a mãe, Sofia relatou apenas que “é boa" e que as duas “conversam muito”. Nota-se que a figura paterna esteve mais presente no discurso de Sofia, que mostrou ter consciência de várias insatisfações vivenciadas na relação com o pai, como já descrito anteriormente. A participante não mencionou o relacionamento extraconjugal do pai, mantendo silêncio sobre essa “ferida” (segredo familiar), assim como Luana. Essa omissão parece traduzir os efeitos de um pacto inconsciente com a mãe: a supressão de certas verdades dolorosas como método para não se purgar do sofrimento e, assim, não permitir que venham à tona as feridas abertas.

\section{O despertar da feminilidade}

Sofia teve a primeira menstruação com 12 anos de idade. Achou "normal”, relatou não ter sentido ou pensado nada a respeito desse acontecimento. Contou para a mãe que, segundo o relato da participante, também não falou nada, e Sofia não sabe se a mãe contou para o pai.

A questão da sexualidade não era assunto abordado na casa de Sofia, mesmo a irmã tendo tido uma filha aos 17 anos, fruto de uma gravidez não planejada. A participante contou que a gravidez da irmã representou uma grande decepção para todos, inclusive para Sofia.

Porque além de eu achar que eu ia me afastar dela, que eu ia perder ela, eu fiquei com ciúmes porque ia ter um bebê dentro de casa... E eu era... Sempre fui a mais nova, né? (Entrevista com Sofia) 
Esse evento parece ter despertado diversas fantasias inconscientes. Sofia sentiu que perderia seu lugar de "bebê" da casa quando a sobrinha nascesse. Tendo o nascimento da sobrinha coincidido com a época do início do TA, pode-se pensar no valor simbólico do adoecimento como uma tentativa de Sofia em manter-se identificado ao lugar de "bebê", que necessita de cuidados extremos - e do alimento - fornecido regularmente pela mãe, não deixando espaço para que esta se interessasse pelo outro bebê que estava a caminho. Nesse sentido, o comer compulsivo parece denotar uma busca pela incorporação do objeto bom - o seio da mãe -, mantendo-se assim fusionada a ela (Miranda, 2007). No momento em que essa coincidência entre o nascimento da sobrinha e o aparecimento dos sintomas de TA foi pontuada pela pesquisadora, Sofia manteve-se em silêncio, parecendo mergulhar todo o seu ser ao olhar fixamente para as mãos entrelaçadas no colo.

A participante começou a se interessar por namoro por volta dos 11 anos de idade, pois “fazia tudo que a irmã fazia”. Portanto, quando a irmã começou a namorar, aos 14 anos, Sofia também começou. As duas eram bastante próximas: saíam juntas, a irmã levava as amigas para casa e incluía Sofia nas conversas. Porém, tudo isso mudou depois que a irmã engravidou, ainda que esta não tenha "juízo para cuidar de uma criança” e deixa a filha ser cuidada pela avó. Sofia parece ter se sentido traída e abandonada pela irmã, assim como esta abandonou a filha para morar com o namorado (que não era o pai da criança).

Ah, ela foi morar com esse namorado dela porque minha família não gosta dele, sabe? E ela preferiu ficar com ele do que cuidar da minha sobrinha. Então eu acho que ela não seria uma boa mãe... (Entrevista com Sofia)

O bebê presentificava a impossibilidade de escamotear a relação sexual. Graça à identificação com a irmã, Sofia podia agora manifestar seu horror pela possibilidade de ficar grávida caso transgredisse o mandamento materno (ainda está muito cedo para você namorar). Por conseguinte, a mãe manifestou sentimentos ambivalentes em relação à menarca da filha: 
Luana contou que se sentiu feliz pela filha estar "ficando mocinha", mas também sentiu tristeza por pensar que a filha já não era mais “seu bebê”.

Ah, eu fiquei feliz né, falei: “Minha filha já tá ficando mocinha”, por que eu falava "meu bebê", né, tá ficando mocinha... É gostoso, mas ao mesmo tempo a gente gostaria que ficasse aquela criancinha... Porque quando começa a desenvolver já começa a pensar em namorado, você já vai... É um pensamento mais preocupante. (Entrevista com Luana)

A fala de Luana remete à angústia vivida devido à possibilidade de que Sofia, ao se desenvolver, passasse a se interessar por outras pessoas além da mãe: no momento em que a filha deixa de ser um bebê, consequentemente deixa de necessitar da mãe como antes, o que parece ser intolerável para Luana, que, inconscientemente, deseja manter a relação de total dependência por parte da filha. Nesse sentido, a filha parece ocupar o lugar de falo da mãe, de algo que lhe possibilita a sensação imaginária de completude narcísica, livrando-lhe do sentimento de falta e do convívio penoso com a castração (Birksted-Breen, 2005; Kehl, 2008). Quando questionada a respeito da preocupação decorrente do desenvolvimento físico da filha, Luana esboçou medo de que acontecesse algo que ela não conseguiu nomear claramente, mas que parecia estar relacionado a fantasias de abuso sexual.

Ah, do tipo que eu te falei, de namorado... Porque o lugar lá que a gente mora a gente sabe que vive todo tipo de gente... Minha preocupação era essa, eu sabia que ela ia namorar porque ela sempre foi corpudinha, né? Então eu fiquei preocupada sim, ela gosta de roupa curta. Ela vem de calça porque é aqui no HC, mas ela gosta de shortinho, gosta de roupa assim. [...] Eu falo assim: "Fia, eu só tenho medo de você sair na rua, porque hoje em dia tem muita gente que não presta”. [...] Ah, que alguém pegue ela, sabe, faça alguma maldade... Meu medo é esse. Porque hoje você vê muito, você vê as meninas com oito anos de idade os homens já ficam mexendo, aí... (Entrevista com Luana)

McDougall (1997) pontua a dificuldade de representação psíquica da vagina, por se tratar de um órgão invisível que gera inúmeras sensações corporais, as quais a menina não consegue localizar e compreender, e que por isso ela precisa da mãe para ajudá-la a integrar 
essas sensações difusas (Ribeiro, 2011). Nesse sentido, a forma anatômica do órgão genital feminino - “invisível” - evoca fantasias, principalmente de ser aberto à invasão, tornando a mulher um representante fácil da vulnerabilidade (Birksted-Breen, 2005). Por se tratar de uma abertura corporal cujo fechamento, diferentemente da boca e do ânus, não pode ser controlado, sua presença desperta na menina a sensação de que esta não poderá controlar o acesso de outros ou de si mesmas (Bernstein, 1998). Trata-se do que a autora chamou de angústia de penetração, que remete ao terror por possuir um "buraco aberto através do qual coisas podem entrar e sair, e que não há como abrir ou fechar, nem controlar o acesso” (p. 199).

Ao tratar o corpo da filha adolescente como algo que deve ser escondido por meio de roupas largas e compridas, Luana coloca a feminilidade como uma experiência a ser temida e evitada, pois representa um perigo à integridade da própria mulher. Há, portanto, uma equivalência inconsciente entre feminilidade e ameaça, entre sexo e perigo, o que possivelmente influenciou negativamente a forma como essa mãe experimenta sua própria sexualidade. Considerando-se que a experiência da mãe com seu corpo de mulher faz parte do processo de desenvolvimento sexual da filha (Ribeiro, 2011), é possível pensar que os significados inconscientes que Sofia irá imprimir em seu corpo feminino serão próximos aos da mãe, ou seja, signos de angústia e temor aterrorizante.

Wallace também relatou algo que se aproxima do temor em relação à vagina e ao feminino: quando questionada a respeito da forma como lidou com a menarca da filha, contou que não soube quando isso aconteceu, pois sua criação havia sido como uma "ditadura”, demonstrando que não poderia se aproximar de nada que denotasse o desabrochar da sexualidade da filha.

[...] Quando minhas filhas nasceram, pra você ter uma ideia, eu nem trocava uma fralda, por ser menina, entendeu? [...] Por ser menina. Porque eu achava que... Não era legal um pai tá trocando a fralda da própria filha. Nunca vi a minha menina de 
dois, três anos tomar banho, peladinha na minha frente. Não, nunca... Você pode achar até machismo, mas é, era... Foi a forma que eu fui criado na nossa cidade. E ainda existe, pros lado do nordeste, esse tipo, entendeu? E cada vez mais que a gente assiste... Que a gente assiste televisão e vê esse negócio de pedofilia dentro da própria casa, a gente fica cada vez mais constrangido em ter uma filha pequena e ver ela pelada, porque tipo assim, acha que quando... Se você tá... Querendo ou não, se vai trocar uma fralda você tá vendo sua filha pelada e alguém pode ver e falar assim "Nossa”. (Entrevista com Wallace)

Entende-se que no discurso de Wallace há temores inconscientes relacionados ao tabu do incesto no tratamento dos pais - genitores do sexo masculino - com suas filhas, o que acabou distanciando-o dos cuidados e manejos físicos do bebê, por exemplo, na limpeza e troca das fraldas. Assim como no discurso de Luana, a feminilidade emerge como algo aterrorizante, impedindo que o pai se aproxime da filha e aprecie seu corpo de menina. A transição adolescente, principalmente com a emergência dos caracteres sexuais secundários no corpo da filha, atrai o olhar do pai para algo assustador, tingindo esse novo interesse inconsciente pela filha com uma conotação incestuosa. Sem pais para traçarem uma geografia de prazer e desprazer em seu corpo (Ribeiro, 2011) e auxiliá-la a dominar as angústias genitais, a filha pode ter criado uma imagem narcisicamente prejudicada de seu self e de sua própria sexualidade (McDougall, 1997).

\section{Relacionamentos afetivos e vida sexual}

No momento da entrevista, Sofia namorava havia nove meses. Relatou que era um “namoro tranquilo", apesar de por vezes “descontar a raiva” no namorado, mesmo não conseguindo identificar os motivos que lhe despertavam esse sentimento destrutivo. Considera-se uma pessoa difícil para se relacionar, pois sente tristeza e nervosismo “de uma hora para outra”, e desconta em quem está por perto, principalmente no namorado. Esse relato parece bastante semelhante aos vômitos, pois remete à impossibilidade de conter 
sentimentos - e alimentos - dentro de si. A impulsividade e labilidade emocional são marcas características de seu funcionamento mental.

Nos relatos sobre o namoro, a participante respondeu as perguntas da pesquisadora de forma bastante pragmática e distanciada, despida de emoções, como se não pudesse reconhecer seus próprios sentimentos e sua ligação emocional com o namorado. Não deu continuidade a nenhum assunto por conta própria, limitando-se apenas a responder ao que lhe era inquirido. A descrição da primeira relação sexual, que foi com o namorado após três meses de relacionamento, também foi desprovida de afeto. Caracterizou a experiência de iniciação sexual como “normal”. Após alguma insistência por parte da pesquisadora, Sofia relatou que nunca teve orgasmo ou prazer no sexo, e que "não se sente à vontade" durante a relação sexual. Recusou-se a contar das conversas que teve com o namorado a respeito da vida sexual do casal, relatando apenas que "ele acha que ela não gosta de ter relação". Acredita que o namorado esteja feliz com a atividade sexual do casal, ainda que Sofia não esteja. Quando a pesquisadora a convidou a pensar em que ela gostaria que fosse diferente, ela não soube responder, demonstrando dificuldade para localizar seu próprio desejo.

[...] Durante todo o tempo da entrevista, tive a sensação de "fechamento", como se a participante não quisesse se expor, ou não conseguisse se expressar. Por vezes me ocorreu o pensamento: "Será que ela não consegue falar sobre suas experiências apenas aqui comigo, ou será que é algo com o qual ela nunca entra em contato?”. (Diário de campo, entrevista com Sofia)

Observa-se que, no discurso de Sofia, a relação sexual caracteriza o que McDougall (1991) denominou de “experiência psíquica insuportável”, possivelmente porque o ato sexual implica necessariamente em estabelecer contato com seu corpo feminino, que já não é mais um corpo de bebê e que insiste em se mostrar sexuado. Hipotetiza-se que há, portanto, um luto não resolvido pela perda do corpo infantil, acompanhado de receio de decepcionar a mãe, que diz repetidamente que "a gente gostaria que ficasse aquela criancinha”. 
Luana, a mãe, relatou ter se sentido "assustada" quando a filha começou a se interessar por meninos e namoro. Inicialmente a participante trouxe que esse "susto" estava relacionado a um medo de que a filha repetisse "a loucura que ela fez" ao casar-se muito cedo, sem estar preparada para a experiência conjugal.

Ah, eu conversei com ela, mas fiquei meio assustada, falava que ela estava muito nova, que ela tinha que ver com quem ela ia namorar... Se era isso que ela queria... Porque 13 anos, eu falo, eu comecei a namorar com o pai dela eu tinha 12 anos, e eu casei com 15, só que eu falo pra ela: "Eu me arrependo”, entendeu? Aí eu falo isso pra ela. "Não mãe, mas eu não tô namorando pra casar”, aí eu falei: "Mas acontece, eu também não namorei pra casar". Aí eu ficava com medo, porque eu falava: “Nossa, eu já não tenho um casamento que é bom”, e eu tinha medo de acontecer o mesmo com ela. [...] Isso, [tinha medo] que ela fizesse o que eu fiz, a loucura que eu fiz, entendeu?[...] Tudo bem que eu casei nova, mas eu nunca quis isso pra elas. (Entrevista com Luana)

Nota-se que Luana traz em seus relatos, ainda que implicitamente, uma ideia do casamento como uma sentença de prisão, uma experiência mortificante que desperta muito sofrimento e que ela não deseja para as próprias filhas. No entanto, em momentos posteriores da entrevista, a mãe também relacionou o medo do namoro da filha com a possibilidade desta lhe ser "tomada" pelo namorado. Quando questionada a respeito de como se sentiu quando a filha começou a namorar, Luana respondeu:

Ah, eu estranhei um pouco, ainda mais que eu achei assim, que ela se afastou um pouquinho de mim. Porque ele vai lá em casa todo dia... Até eu brinco com ela assim, eu brinco, mas eu tô falando sério, eu falo: "Você tá tomando a minha filha de mim". Porque acaba tomando, ela acaba se afastando um pouco. Eu estranhei sim. [...] Só que eu acho bom também que quando ele tá lá pelo menos ela não tá no quarto trancada, né? Mas... Ela ficava no quarto assim, aí ela saía, às vezes eu tava na pia, ela chegava, me abraçava... Porque ela é bem grudenta também. Mas... Eu assustei sim, achei estranho. (Entrevista com Luana)

Nas falas mencionadas acima, é possível notar a comparação que a mãe faz entre o lugar que ela mesma ocupa na vida da filha e o namorado, como se este último estivesse ocupando o lugar que costumava ser originalmente dela: antes Sofia saía do quarto e ia até a 
mãe, abraçava-a enquanto ela estava na pia; após o início do namoro, a mãe percebe que a filha sai do quarto para ficar com o namorado. Nesse sentido, o discurso de Luana remete à angústia pela possibilidade da entrada de um terceiro em sua relação com a filha, como se o namorado pudesse romper a relação fusional da dupla.

Quando Luana relata que a filha estava “se afastando” dela em função do namoro, evidencia-se o medo do abandono. Entretanto, o seguinte trecho do diário de campo da entrevista realizada com a mãe remete ao medo dela própria abandonar a filha, indicando a dependência mútua presente na relação da dupla e suas marcas profundamente narcísicas:

No final da entrevista, ao se despedir, Luana disse: "Vou lá encontrar a Sofia, ela deve achar que eu abandonei ela". Essa fala da participante me suscitou o pensamento de que talvez ela goste dessa dependência de Sofia, principalmente porque ela - Luana - parece ter a mesma dependência e, assim, sente-se correspondida. (Diário de campo, entrevista com Luana)

Como já mencionado anteriormente, quando mãe e filha se encontram em uma relação fusional e simbiótica, a emancipação emocional da filha, assim como sua independência e desenvolvimento da sexualidade, são extremamente angustiantes para ambas (HalberstadtFreud, 2001; Ribeiro, 2011). Mãe e filha encontram-se presas em uma relação na qual não há espaço e disponibilidade interna para viverem outras relações. Tais relações configuram ameaça à existência de cada uma, uma vez que mãe e filha existem apenas enquanto extensão uma da outra. Considerando esses pressupostos, o namoro de Sofia parece emergir de forma latente no discurso da mãe como uma ameaça à sua própria integridade psíquica: se a mãe vive a vida da filha, o que aconteceria com essa mãe se a filha passasse a viver sua própria vida com um terceiro? Pode-se hipotetizar que, no caso da filha passar a se dedicar mais ao namorado, Luana não teria outra saída que não fosse voltar o olhar para sua própria relação conjugal e para as profundas frustrações e insatisfações vivenciadas, as quais preferiu - de forma inconsciente - ejetar de seus pensamentos. 
Wallace, por sua vez, confidenciou ter recebido uma educação bastante severa na infância, pois tinha um pai muito rígido que batia nos filhos. Essa foi a forma de educar que ele conheceu e, consequentemente, internalizou como modelo de cuidado parental, que tentou aplicar na educação de suas próprias filhas. Relatou que bateu nas duas por várias vezes, principalmente quando desobedeciam suas ordens. No entanto, quando Sofia começou a apresentar os sintomas de TA e a automutilação, Wallace questionou se a educação que dava à filha estaria sendo rígida demais, a ponto de causar-lhe os problemas que ela havia passado a apresentar. Por esse motivo, tentou ser mais maleável no cuidado da filha, o que implicava em conceder-lhe permissão para namorar.

A princípio quando ela começou a namorar, eu... Me incomodava muito, entendeu? Sabe... Mas eu vi que... Eu fui conhecendo o rapaz... Ele é filho único, um rapaz... É trabalhador, que eu vi que tava fazendo bem pra ela... Pelo contrário, eu não sei como que ele aguenta ela (risos). Tem dia que ela tá num... Num humor insuportável. Entendeu? Tá fazendo bem pra ela. Liberei, a hora que ele pede pra sair com ela, seja dia no meio de semana, tudo bem... Pra ver. Eu falei "Uai, eu acho que o erro era meu." Mas só que as coisas continuam do mesmo, ela num... Eu não vejo ela mudar sobre essa questão de, de... Do problema dela. (Entrevista com Wallace)

Além disso, Wallace também relatou o medo de que a filha se interessasse por um “malandro”. Certa vez, soube por um colega que Sofia estava envolvida com um garoto que “mexia com drogas”. Indignado, proibiu terminantemente o namoro.

Aí eu... Proibi. Eu falei pra ela "Eu não quero. Se eu souber que você tá namorando com ele..." eu vou usar as palavras exatamente que eu usei, "E se eu souber que você continua namorando com ele, se eu te ver... por aí, pela pracinha... é... Eu bato em vocês dois. Eu bato em você e bato nele." [...] Eu não vou mentir, eu bati nela umas duas, três vezes por causa desse cara. Entendeu? (Entrevista com Wallace)

Saber do que acontece na vida das filhas por terceiros é algo bastante frequente no relatos paternos. É como se o pai estivesse excluído do que acontece com as filhas no âmbito emocional e afetivo, sendo encarregado apenas de suprir as necessidades materiais do lar. 
Nota-se, portanto, que a família Moraes se caracteriza por ostentar o ideal da família tradicional, remanescente do patriarcado, no qual o pai é definido como alguém emocionalmente distante, voltado para o mundo trabalho e responsável por prover o sustento da casa (Beltrame \& Bottoli, 2010). Em contrapartida, também se pode notar que o pai busca a todo momento participar da vida e da educação das filhas, mas é interditado pela esposa.

[...] Eu falava [para a esposa]: “Ó, agora pra isso eu sou pai? Sempre que eu ia corrigir você falava que eu não tinha moral, por causa disso, disso e disso. Agora, por causa desse problema agora [o TA] você me vê que eu sou o pai delas? Pra por dinheiro dentro de casa eu sou o pai delas? Pra comprar coisa pra elas eu sou o pai delas, agora... Na hora de corrigir eu não sou pai, não tenho moral, nunca fui um bom pai, não é isso?” (Entrevista com Wallace)

Além disso, Wallace também relatou que batia nas filhas por sentir que ambas “estavam desafiando sua autoridade de pai”, ou seja, trata-se de um pai que, além de excluído da vida familiar, também se sente falicamente desmoralizado dentro da própria casa e que necessita se impor utilizando a única força de que se considera detentor - a força física - para ser respeitado enquanto figura de autoridade. Tal desfalicização do pai remete ao esvaziamento da imago paterna, que teve início a partir dos discursos feministas e homossexuais que "romperam radicalmente com os pressupostos do patriarcado" (Birman, 2006, p. 168). Assim, a superação do patriarcado e as novas formas de subjetivação parecem resultar no desaparecimento do imperativo da autoridade paterna, fazendo com que os genitores do sexo masculino necessitem ressignificar seu papel dentro da família. 


\subsubsection{Família Batista}

Ana Júlia, a filha: "Foi totalmente monstruoso"

Antônia, a mãe: "Então aí, quando eu fiz os 15 anos dela...”

Cido, o pai: "Eu não vi meus filho crescer, né?”

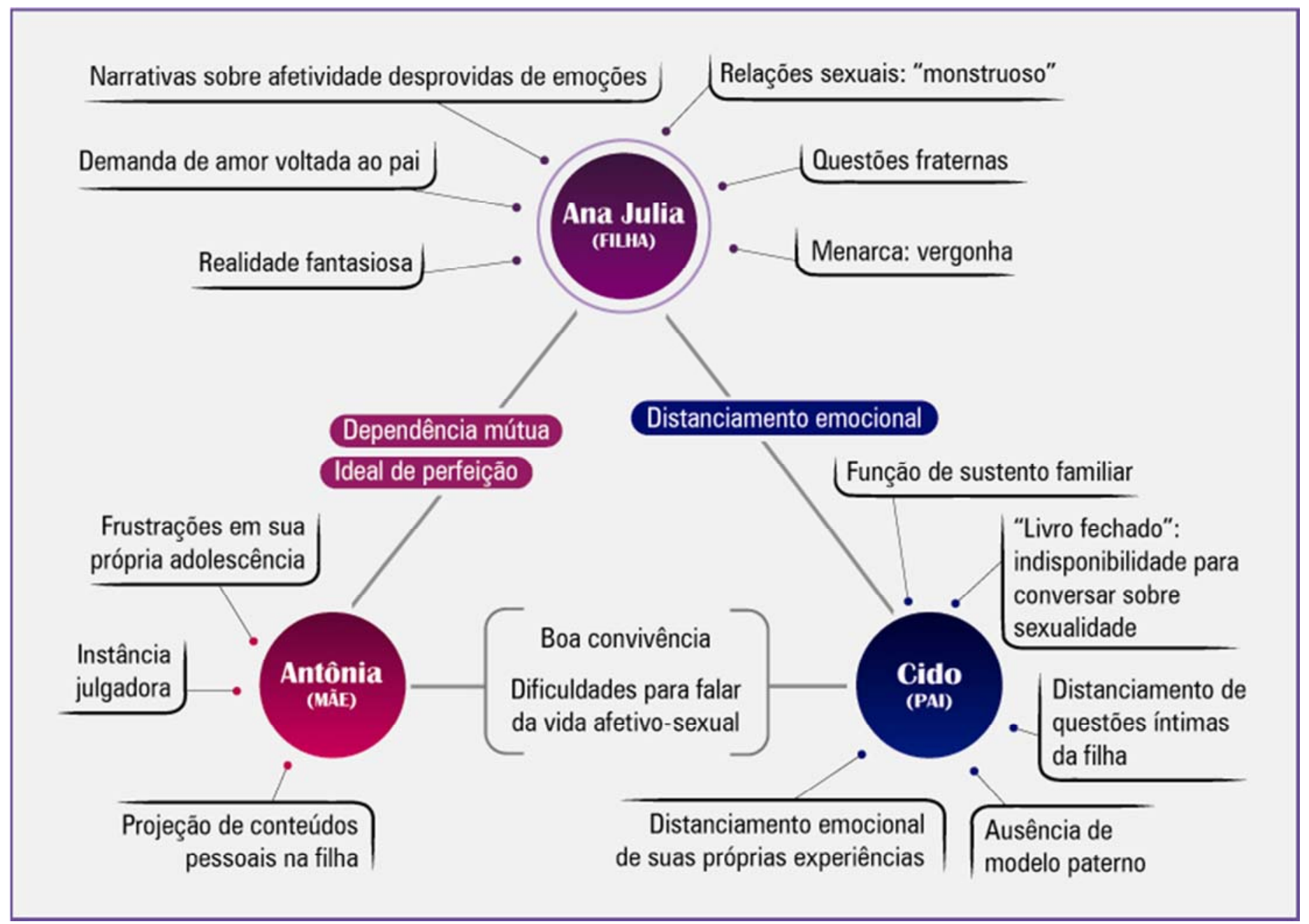

Figura 2. Mapa de associação de ideias da família Batista. 
Ana Júlia iniciou o tratamento no GRATA em março de 2013, com 23 anos de idade, devido a episódios frequentes de compulsão alimentar, seguidos de vômitos. Relatava, na época, que sentia fome, mas não tinha vontade de comer. Sentia nojo de mastigar os alimentos e, quando conseguia engoli-los, sentia necessidade de induzir o vômito. Recebeu o diagnóstico de AN do tipo bulímico e apresentava traços de transtorno de personalidade borderline e transtorno obsessivo compulsivo. Pesava 43,3 kg, tinha 1,58 $\mathrm{m}$ de altura e IMC = $17,3 \mathrm{~kg} / \mathrm{m}^{2}$, considerado abaixo do ideal para a idade e altura da participante, e indicando possibilidade de desnutrição.

Na época da entrevista, Ana Júlia encontrava-se em seguimento no GRATA havia quatro meses. O peso havia diminuído (40,9 kg), assim como o IMC (17 kg/m²). Segundo os dados do prontuário, a participante apresentava graves resistências ao tratamento, evitando seguir as recomendações médicas e nutricionais, o que tem relação com a diminuição do peso corporal. No momento da entrevista, Ana Júlia estava vestida com calça jeans, blusa cinza, casaco preto fino e sapatilha preta. Falava baixo, mantinha as mãos unidas no colo e as pernas também unidas. Manteve a postura ereta e quase não se mexia durante a entrevista.

A renda da família Batista, segundo relato do pai, era de aproximadamente 4.000,00 reais - havia considerado apenas sua própria renda, e não a dos filhos que já trabalhavam. No entanto, o resultado do CCEB/2015 indicou que a família se encaixa no estrato socioeconômico A, que inclui rendas familiares de aproximadamente 20.272,56 reais. Acredita-se que a grande divergência de dados entre o relato do pai e o resultado no CCEB/2015 tenha se dado em função da configuração familiar relacionada à moradia: os pais moravam em uma chácara em outra cidade, e Ana Júlia (que respondeu ao CCEB/2015) morava em uma casa com seis irmãos. Na época da entrevista, três irmãos haviam se mudado após o casamento. Entretanto, apesar da saída dos irmãos da casa, Ana Júlia computou itens no CCEB/2015 que eram de posse desses irmãos, por exemplo, carros, motocicletas, 
computadores, entre outros. Portanto, o resultado apontado pelo instrumento engloba a renda de todos os membros da família $(n=9)$ juntos.

\section{O transtorno alimentar}

Ana Júlia contou que seus problemas com a alimentação estão relacionados a não conseguir engolir o alimento, por "achar nojento" o ato de mastigar e por ter o pensamento de que o alimento ficará dentro de seu estômago. Além disso, quando começou a sentir esse “nojo”, a participante estava passando por um período que ela nomeou como "estado depressivo”, no qual permanecia fechada em seu quarto a maior parte dos dias e tinha medo de sair na rua.

Quando questionada a respeito de experiências que poderiam estar relacionadas com o “estado depressivo”, Ana Júlia narrou uma série de tribulações e eventos adversos ocorridos quase simultaneamente: morte do primo, morte da amiga em acidente de moto, morte de um amigo da família e até mesmo um incidente ocorrido no Rio de Janeiro, que suscitou comoção nacional, quando um jovem entrou em uma escola e atirou a esmo em crianças, ferindo e assassinando diversas. Nota-se que todas essas fatalidades e eventos dramáticos envolvem mortes prematuras e tragédias que acometem jovens e crianças, tanto próximas do seu círculo de relações como distantes de sua rede pessoal. Para Ana Júlia, era difícil sair da proteção que sentia no confinamento de seu quarto e frequentar lugares e espaços sociais onde as pessoas circulam, devido ao medo constante de que uma tragédia poderia acometê-la.

Eu até fui um dia no Carnabeirão [evento a céu aberto, no qual as pessoas cantam e dançam ao som de um trio elétrico] e eu quis voltar, não quis ficar, porque eu... Aquele monte de gente já me dava desespero, aí eu já pensava que alguém ia entrar com arma e ia sair atirando no povo, ou que fosse sair alguma briga, que eu não gosto de ver briga porque eu choro e tal, fico desesperada... Aí na mesma hora que eu entrei no Carnabeirão, o meu irmão teve que voltar e vir me buscar, porque eu não queria ficar ali. (Entrevista com Ana Júlia) 
Essa situação descrita se assemelha muito a um ataque de pânico. Ao tentar aprofundar a questão do “desespero" narrado pela participante, a pesquisadora percebeu uma mudança em seu comportamento - encolheu os ombros e abaixou a cabeça - e seu tom de voz ficou rebaixado ao confidenciar que não conseguia entender o motivo de sentir desespero em relação à possibilidade de morte. Esses dados remetem a uma dificuldade da participante de aceitar também as perdas da infância, ou seja, da “Ana Júlia criança” e, assim, aceitar seu próprio crescimento, os relacionamentos sociais e, de forma geral, as adversidades que podem surgir a partir do contato com o mundo externo, fora do ambiente protetor do quarto.

Para Antônia, o TA da filha teve início aos 15 anos de idade, após uma decepção amorosa que ela experienciou com o "príncipe” de sua festa de aniversário. Contou que fez uma festa de 15 anos para Ana Júlia “com tudo o que uma menina quer”, e o príncipe seria um colega de escola da filha, por quem ela era apaixonada. No entanto, o garoto não quis lhe dar o beijo do príncipe, pois, segundo o relato de Antônia, sabia que Ana Júlia era apaixonada por ele e "ele não é homem para namorar moça séria". Antônia acreditava que, depois desse evento, Ana Júlia se “desencantou” e por isso nunca namorou, não tinha o hábito de sair e acabou por desenvolver o TA.

Eu achei, da parte dele, que ele foi muito sincero, só que pra ela foi uma decepção grande, que a primeira pessoa que a gente gosta, a gente nunca esquece, né? Sempre tem o primeiro amor, a primeira paixão... Tudo, o primeiro beijo... Então né, aí fica... Foi decepcionante pra ela, ela não tinha outro lugar pra correr ou pra se agarrar a não ser nesse problema que ela veio a desenvolver, que é o distúrbio alimentar, então... (Entrevista com Antônia)

Ao narrar os acontecimentos da festa de 15 anos, Antônia se referia ao "príncipe" com mágoa e ressentimento, que fizeram com que a pesquisadora pensasse na possibilidade de que a decepção por não ter havido o "beijo do príncipe” se tratava de um desapontamento narcísico vivenciado não apenas pela filha, mas também - e talvez mais intensamente - pela 
mãe. Partindo dessa conjetura, a pesquisadora procurou investigar mais a fundo as circunstâncias da festa.

Ela queria muito, muito, foi tudo perfeito, tudo do jeitinho que ela queria, mas... Decepção, né. Por um lado eu me vi realizando um pouquinho da minha adolescência na festa dela e, por outro lado, eu fiquei decepcionada até agora com essa história de príncipe não ter o beijo, então... (Entrevista com Antônia)

Nota-se, portanto, que a festa de 15 anos - incluindo o "beijo do príncipe” - era um desejo da mãe desde a sua própria adolescência. E que permaneceu em suspenso por tantos anos, até finalmente ter sua possibilidade - que terminou sendo frustrada - na festa dos 15 anos da filha.

Na minha época não tinha essas mordomias que tem hoje, até estudar a gente não estudava direito porque tinha que trabalhar, né. E aí eu tive cinco filhos, depois tive ela, aí eu falava: "Vou fazer uma festa de 15 anos pra minha filha", e ela sempre: "Ai mamãe, quero a festa, quero a festa, tal... Quando eu fizer 15 anos quero uma festa, mas quero que você escolhe bonitinho pra realizar o teu sonho". Eu nunca tive uma festa de aniversário, nunca tive um parabéns, assim, quando eu era pequena, até os meus 18, 19 anos, nunca ninguém chegava em mim e: “Oi, parabéns, felicidades”, me dava um abraço, nem pai, nem mãe, ninguém... A gente vivia mais pra trabalhar, religião e mais nada, aí depois que eu fiz os meus 19 anos, aí eu fui saber o que é uma festa de aniversário, o que é ganhar um abraço, não presente, mas um abraço sincero, gostoso, sabe? Porque o dia que a gente nasce é um dia que marca, né, então aí quando eu fiz os 15 anos dela, eu me senti um pouquinho junto com ela, na festa, foi legal. (Entrevista com Antônia)

Partindo-se do pressuposto de que a festa de 15 anos e o príncipe eram desejos irrealizados da mãe, e que não houve o "beijo do príncipe”, culminando com a “decepção”, pode-se pensar que a frustração foi potencializada como uma experiência de sofrimento materno que Ana Júlia tomou para si, por não ter podido realizar o desejo da mãe. Bruch (1978) foi a pioneira em chamar a atenção para o tipo de relacionamento peculiar que filhas com anorexia mantêm com suas mães. Segundo Miranda (2011), a relação mãe-filha é um dos elementos nucleares nos TAs: de modo geral, a filha percebe a inconsistência da relação conjugal dos pais e a consequente fragilidade da mãe, e se identifica com suas partes faltantes. 
Desse modo, a filha tentará preencher o vazio da mãe, e viverá afetos que não são apenas seus, mas que são provenientes da fusão de suas próprias experiências afetivas com as da mãe ("Quando eu fizer 15 anos quero uma festa, mas quero que você escolhe bonitinho pra realizar o teu sonho"). A festa de 15 anos e o beijo do príncipe parecem se tratar de ideais da mãe que não puderam ser realizados em sua adolescência, e que Ana Júlia mimetiza ao se ver, inconscientemente, encarregada de realizar, como se recebesse um mandato invisível, identificando-se com aquela que poderia suprir a demanda materna, em uma reedição extemporânea da adolescência da mãe.

Cido, o pai, relatou que não consegue atribuir um motivo específico para o início dos sintomas de TA da filha, pois passava muito tempo fora de casa trabalhando e não percebeu quando Ana Júlia começou a emagrecer, tendo atentado para a gravidade do problema apenas quando a esposa chamou sua atenção. Quando questionado a respeito de possíveis eventos que aconteceram na vida da filha na época do início do transtorno, e que, na opinião dele, poderiam estar relacionados com o quadro psicopatológico, Cido respondeu:

Então, cê sabe que isso até hoje eu me cobro? Eu não 'anotei', você vai me desculpar, mas eu não sei se... Aquele negócio de 'boe-boe-boemia', não sei nem falar essa palavra. [...] Bulimia, eu nem, eu não percebi, eu vi que naquela época começou a surgir essas conversas aí, foi mais divulgado, que existia, mas só que foi mais divulgado, aí que eu fui... Aí eu fui descobrir, mas eu achava que também ela não tinha esse tipo de problema, sabe, porque a gente notava esse assunto nela, porque ela não comia mesmo... Aí nesse caso aí, foi um caso meio chocante pra mim, sabe, eu não esperava isso aí... (Entrevista com Cido)

Nota-se, portanto, que Cido apresentava dificuldades para compreender o que é a BN. E, antes de “compreender", no sentido cognitivo, aceitar, o que envolve um processo de elaboração mais afetiva do que racional. A recusa de admitir o transtorno da filha, como se fosse algo abominável, faz Cido ter dificuldade de nomear o sofrimento da filha. Não se trata de uma simples dificuldade de conhecimento médico, pois após hesitar, ele rapidamente ele nomeia corretamente a categoria diagnóstico na qual a filha foi categorizada (“bulimia”). 
Interessante que o primeiro significante utilizado (“boemia”) parece apontar para um tipo de comportamento transgressivo relacionado a excesso, desregramento e busca de conforto na bebida, geralmente identificado como próprio do sexo masculino. No entanto, em momento posterior à entrevista, o pai narrou a mesma decepção amorosa contada por Antônia, que Ana Júlia vivenciou aos 15 anos de idade e que, na opinião dos pais, fez com que a filha adoecesse. Não soube explicar o que aconteceu entre Ana Júlia e o menino por quem era apaixonada, pois não se envolvia na vida afetiva da filha, como pode ser percebido no seguinte excerto de fala:

[...] Agora, os meu filho, eu procuro eles não fazer coisa errada, as minhas filha, assim, ela pode namorar quem ela quiser, se for uma pessoa, assim, que... eu acho que a gente tem que conhecer, sabe? Não quero que a minha filha namora uma pessoa que não... não que, assim, que não é honesto... (Entrevista com Cido)

Pode-se supor que, para Cido, a função paterna envolve conhecer a pessoa com quem seus filhos se relacionam e emitir o aval para que o relacionamento aconteça sob o beneplácito dos pais. Porém, claramente o pai não se deixa envolver em questões que vão além de “dar a palavra final”. Assim, as experiências emocionais e os sentimentos de satisfação ou infelicidade vivenciados nos relacionamentos afetivos não são conversados entre pai e filha. Evidencia-se que a relação pai-filha na família Batista se inseria nos moldes da sociedade tradicional (patriarcal) que ditavam o exercício da paternidade, nos quais o pai permanecia à margem das dimensões afetivas da família nuclear, sustentando sua posição de figura de autoridade responsável pela provisão financeira e mantendo relativo distanciamento das questões internas da casa e da dinâmica familiar (Beltrame \& Bottoli, 2010).

O distanciamento emocional do pai e a consagração da mãe como única responsável pelo cuidado da filha abre amplo espaço para que a filha ocupe o lugar de extensão psíquica da mãe, buscando satisfazê-la narcisicamente (Halberstad-Freud, 2001; McDougall, 1991, 1997). Portanto, a atitude do pai representa um aspecto de suma importância no 
desenvolvimento emocional e psicossexual da filha: para que execute sua função de interditor da relação mãe-filha, é necessário que o pai seja um abrigo, represente um porto seguro para esta última, ainda que possa não estar fisicamente tão presente quanto a mãe.

\section{As relações familiares}

A participante é a sexta filha de uma prole de cinco irmãos. Portanto, ocupa uma posição muito peculiar na dinâmica familiar, definida pela ordem de nascimento. Tendo sido a primeira filha do sexo feminino, depois seguida de mais uma irmã, sofreu as vicissitudes esperadas de uma caçula que convivia em meio a um ambiente fortemente influenciado pelo signo masculino. Ou seja, Ana Júlia tinha cinco irmãos mais velhos - todos do sexo masculino - e uma irmã mais nova. Segundo a participante, sua relação com os pais era de muita dependência para a realização de tarefas concretas, tais como entregar currículos para buscar emprego: não conseguia entregá-los sozinha, pois sentia "medo e vergonha de falar" com as pessoas. Portanto, os pais precisavam levá-la de carro e estar ao seu lado para que ela pudesse desempenhar essa tarefa. Esses dados remetem a uma dependência emocional - que não se traduz apenas em um plano concreto - dos pais, sem os quais a participante sente-se frágil, uma "porcelana”, como se pudesse se fragmentar diante da mínima pressão sofrida.

[...] E eles vê assim que a minha irmã é mais independente, assim, dos meus pais e vê que eu ainda sou aquele, aquela coisinha de porcelana muito frágil... E pra tudo tem que ter alguém perto, quando eu cortei meu dedo minha irmã foi, minha mãe teve que ir no hospital lá pra me ver dar três pontos no meu dedo, teve que ir... E eles, eles acham assim, já que eu não tenho namorado, "alguém tem que se preocupar em tempo integral com a Ana Júlia", tanto com a alimentação, quanto com cuidado de... De tá presente assim do lado dela pra ir fazer alguma coisa, se não ela não consegue ir”. Então é realmente isso mesmo, eu não consigo ir... (Entrevista com Ana Júlia)

Ao escutar o trecho acima, retirado do relato de Ana Júlia na entrevista, a pesquisadora vivenciou a sensação de que a dependência da participante em relação a seus pais despertava neles algo que, para ela, era sentido satisfatoriamente como preocupação: sua personalidade 
frágil, do tipo "porcelana”, parecia fazer com que os pais e os irmãos estivessem sempre presentes, ocupando-se com seu cuidado e se preocupando com seu bem-estar.

Então eles percebem assim que, às vezes, assim, eu desisto fácil das coisas por medo ou por vergonha mesmo de falar. Então eles percebem que eu preciso deles, por mais que eu vou tirar carta, ter meu carro, mas eu ainda vou precisar deles, assim... (Entrevista com Ana Júlia)

Bruch (1978) notou que as pacientes com TAs tendem a ter autoestima rebaixada e sentimento de não ter competência pessoal para desincumbir de suas tarefas e desafios cotidianos. Tanto Ana Júlia quanto seu pai mencionaram o longo tempo que passaram quase sem verem um ao outro durante a infância da filha. Evidenciou-se que houve uma aproximação entre pai e filha após a ocorrência do TA, quando o pai foi instigado pela esposa a voltar o olhar para a filha, que se encontrava gravemente emagrecida. Pode-se pensar na função psíquica que o TA desempenha na dinâmica dessa família. Uma delas seria a de aproximar o pai da filha, uma vez que, antes do início do quadro, ambos mantinham uma relação distanciada do ponto de vista emocional.

Então, a gente num, num... Eu pessoalmente não descobri, assim, não dei falta porque eu quase não ficava, né, na hora de se alimentar... Eu trabalhava, depois quando eu parei, aí eu já quase não ficava em casa, ficava mais em $C$. [cidade onde os pais residiam]. E quando vim descobrir foi agora, que ela tava emagrecendo, aí minha esposa me alertou: "Olha, ela tá com tantos quilos, não sei o que, eu acho que ela não pode nem trabalhar, porque ela não tem peso", ela tava fazendo curso, a gente pagando... Aí que foi que eu fui descobrir [...] (Entrevista com Cido)

Cido relatou que sempre optou por se manter distante da vida amorosa dos filhos e que nunca opinava nos relacionamentos afetivos. Contou que, desde que os filhos sintam que gostam da pessoa com quem estão se envolvendo, e que se trate de uma pessoa honesta, aceita o namoro. Nota-se, pelo relato do pai, a dificuldade de envolvimento na vida emocional dos filhos, ou seja, as experiências afetivas e os sentimentos decorrentes não são compartilhados entre pai e filhos. Essa atitude de reserva se estende também aos outros assuntos de interesse 
dos filhos e filhas. Para a filha que se encontra em processo de desenvolvimento, essa atitude pode ser interpretada como omissão, negligência ou até mesmo indiferença. Se a filha enfrenta dificuldades de perceber seu valor próprio, isso pode ser vivenciado como mais um indicador de desvalorização, evidência de sua insignificância.

O distanciamento emocional parece ter sido naturalizado no psiquismo de Cido, uma vez que, até o momento da entrevista, não havia pensado sobre algumas questões referentes à vida afetiva de Ana Júlia. Nesse sentido, considera-se que a realização da entrevista favoreceu que o pai pudesse se permitir pensar e reavaliar sua participação na vida emocional da filha, uma vez que a função paterna não se restringe a sustentar sua posição em relação ao mundo do trabalho, à provisão de mantimentos e à autoridade do lar (Beltrame \& Bottoli, 2010).

Eu não procurei ir a fundo no assunto, mas foi até bom você me alertar pra isso aí, que eu vou perguntar pra ela, assim, foi até bom você me alertar, porque... eu não... Sabe quando você não se importa com uma coisa, com a vida dos outros? Então você não tem... mas eu vou... Foi bom você me alertar, eu vou perguntar pra ela que fim que levou, quê que tá fazendo... Que ela deve ter comentado alguma coisa e eu não prestei atenção, porque não era assunto meu, mas foi bom você me alertar, eu vou perguntar pra ela. (Entrevista com Cido)

Cido sente-se constrangido perante a entrevistadora, ao buscar justificar sua atitude usual ("porque não era assunto meu”), o que denota que o sentido que ele atribui ao ser pai prevê assuntos que são de sua alçada, como pai, e assuntos que não são - por exemplo, os que remetem à vida subjetiva dos filhos. Não é algo endereçado especificamente à filha, mas ao conjunto de filhos de sua extensa prole. Os relatos de Antônia, por sua vez, foram bastante convergentes aos do marido, ao descrever a relação de preocupação existente entre os membros da família, principalmente no que concerne à Ana Júlia. Contou que a filha se preocupa muito e sofre quando seus pais ou irmãos enfrentam algum problema de saúde. No entanto, a preocupação parece ser bastante direcionada à mãe, pelo fato de a filha considerá-la perfeita. 
[...] E ela acha que não tinha que acontecer comigo, pode acontecer com qualquer pessoa, menos comigo, pode acontecer com ela e com qualquer um, menos eu, ela acha que eu sou perfeita e eu falei pra ela: "Eu não sou perfeita”. [...] Ela acha que eu sou perfeita, a mãe que faz tudo muito bem feito, tudo direitinho, deu educação pra nós tudo direitinho, tem que andar naquele padrão. Não, não sou, eu erro também, tenho bastante erro, mas eu converso muito com ela isso. (Entrevista com Antônia)

Pode-se pensar que, da mesma forma que a preocupação da mãe é vivenciada de forma satisfatória pela filha, a recíproca também parece ser verdadeira: a mãe não consegue ocultar sua satisfação ao perceber a preocupação da filha, vista como mais um elemento que reforça a dependência de Ana Júlia. Também se sente gratificada ao ser entronizada pela filha com o estigma da "perfeição”, termo que foi utilizado várias vezes pela mãe durante a entrevista - e em nenhum momento pela filha.

É, tem hora que eu falo as coisas pra ela, ela tá lá no quarto dela, eu vou lá e falo, eu volto lá na sala e: "Ai, meu Deus, não era isso que era pra eu ter falado", aí volto lá e falo: "Ana, tá tudo bem?", ela fala: "Tá, mãe", "Você achou ruim do que a mãe falou?", "Não, mãe”, "Filha, você desculpa a mãe? A mãe não é perfeita, me desculpa, não era isso que ia falar”, "Não, mãe, mas sabe que aquilo que você falou tem fundamento? Eu tô pensando no que você falou, porque o dia que você falar alguma coisa que eu não gostar, eu vou deixar passar um tempo, vou te chamar e a gente vai conversar” [...] (Entrevista com Antônia)

O relato da mãe foi escutado pela pesquisadora como algo pronto, dissociado da realidade e que provavelmente remetia a algo que a participante acreditava que a pesquisadora gostaria de ouvir, por identificar como parte dos ideais da atitude materna: remeteu a um desejo de ser, de fato, considerada a mãe perfeita pela filha, e de que a pesquisadora também considerasse que as atitudes que assumia enquanto mãe eram adequadas. Outro aspecto também bastante presente nas falas de Antônia é a ressalva que ela procurou frequentemente fazer da importância que ela tem para os filhos.

“Oi, A. [filho], tá tudo bem?”, aí ele fala: “Ah não tá”, aí eu falo: “Filho, vem, senta aqui perto da mãe e vamos conversar", "Ah, não quero conversar agora”, "Tá bom, então, a hora que você quiser conversar eu tô aqui”, aí ele vai lá pro quarto dele, 
toma um banho e volta: "Ah mãe, sabe, desculpa por ter falado isso que eu não queria conversar, mas só você me entende.” [...] (Entrevista com Antônia)

Pode-se pensar que o desejo inconsciente que Antônia alimenta de encarnar “ $a$ mãe perfeita" esteja relacionado ao medo, também inconsciente, de ser abandonada pelos filhos, uma vez que o ser mãe tem sido sua função precípua dentro da família havia muitos anos, desde o nascimento do primeiro de seus sete filhos. Segundo Halberstadt- Freud (2001), ao perceber a fragilidade da mãe e a dependência emocional que esta mantém dos filhos, a menina encontra dificuldades para se separar e desenvolver sua independência, autonomia e sexualidade. O desejo de separação pode ser experimentado pela filha como deslealdade ou agressão à mãe, em função da fantasia de que esta se sentirá traída. Nesse sentido, mãe e filha parecem ter desenvolvido uma relação fusionada, na qual Ana Júlia se manteve como a “porcelana” delicada e quebradiça, a menina que precisa dos cuidados intensivos da mãe para não deixar de existir, de modo que isso mantém Antônia como a mãe “perfeita”, responsável pelos cuidados da filha adoecida.

De forma análoga à gratificação narcísica auferida pela mãe por ser considerada “perfeita” pela filha, Ana Júlia também trouxe o relato de ter sido intensamente desejada pela mãe. Contou que a mãe sempre quis ter uma menina, pois a filha carregaria seu sobrenome, diferentemente dos outros filhos. Além disso, Ana Júlia também contou que a mãe apresentou quadro de depressão após o nascimento do último filho - o quinto da linhagem -, pois desejava uma menina, e também entrou em depressão após o nascimento da última filha mais nova do que Ana Júlia - pois, segundo a participante, a mãe “não queria a outra filha”.

[...] "Não, mas eu quero uma menina! Eu quero uma menina porque vai ter meu sobrenome e tal, que não sei que tem... quero cuidar e tal...”. E daí nesse último irmão meu mais novo, assim, dos homens, ela entrou em depressão... Porque ela não queria ele, ela queria que tivesse vindo uma menina, ela entrou em depressão, não queria ver ele de jeito nenhum, até foi minha tia, minha vó que cuidou do meu irmão, né? [...] E daí teve uma vez que eles tentou de novo, daí ela tava grávida. Aí minha mãe contou pro meu pai, isso ela me contando depois, falou assim: “Ó, se não for 
menina você pode dar pra adoção que eu não vou querer”. [...] Quando deu pra ver certinho, viu que era uma menina, minha mãe morreu, quase morreu... Quase morreu do coração que... E gritava pra todo mundo que era uma menina, chorava de noite, assim, passando a mão na barriga: "Eu não acredito que eu vou ter uma menina $e$ tal...”, e o meu pai todo emocionado, né, que ia ter uma menina e tal... (Entrevista com Antônia)

Nota-se, portanto, uma fantasia de ser a única filha amada e desejada pela mãe. A perfeição da mãe aparece como garantia da existência da filha, ou seja, de seu sentimento de existir para outrem, de ser alguém de valor aos olhos do outro. É também o que avaliza a fantasia de ter nascido do desejo extremado da mãe, o que nutre a fantasia de ser aquela que tem o poder de complementar seus desejos, suas faltas, seus furos. Em contrapartida, a mãe relatou que “queria ter ficado só nos meninos”, pois já tinha cinco filhos. A gravidez de Ana Júlia foi inesperada, aconteceu de forma repentina, mas revestida de significado de um acontecimento maravilhoso.

Aí de repente eu engravidei de novo e tive a Ana Júlia. Foi muito maravilhoso, porque eu achava que eu só ia ter filho homem, aí tive ela e falei: “Legal, muito bom” [...] (Entrevista com Antônia)

Apesar de não haver descrito o recebimento da notícia da gravidez de Ana Júlia com o mesmo entusiasmo com que a filha a descreveu - já que a narrativa da filha era baseada em fatos contados pelos pais, mas também associados e entrelaçados com seus próprios desejos e fantasias -, Antônia demonstrou o intenso desejo de ter uma filha para realizar sua festa de 15 anos. Como já descrito anteriormente, a festa de 15 anos era um desejo de Antônia que fora frustrado em sua adolescência, em função das parcas condições financeiras e dos costumes de sua família, na qual os membros começavam a trabalhar desde cedo e "viviam para trabalhar”. Evidencia-se que, antes mesmo de sua concepção e nascimento, Ana Júlia já contava com um lugar no psiquismo da mãe, que envolve a necessidade de preenchimento de 
lacunas decorrentes das frustrações de sua própria adolescência, como a festa de debutante nunca usufruída e o esperado "beijo do príncipe”.

Kehl (2008) sugere que a representação que cada indivíduo tem no inconsciente dos pais e o que herda das gerações passadas marca o seu próprio desejo. Tal representação preexiste ao nascimento do filho, uma vez que este já existe de algum modo no psiquismo dos pais. Devido às semelhanças físicas, anatômicas e de gênero, há grandes chances de ocorrerem identificações entre mãe e filha, nas quais a filha poderá ser inconscientemente encarregada de preencher as possíveis insatisfações narcísicas da mãe, tornando-se sua extensão. Tomando-se por base esses pressupostos, é possível compreender que o "beijo do príncipe” era um desejo compartilhado entre mãe e filha, e que o não acontecimento desse beijo gerou uma frustração também compartilhada entre as duas, não como individualidades distintas, mas como complementos uma da outra. Enquanto prolongamento materno, Ana Júlia parece ter sofrido uma dupla frustração: a sua e a de sua mãe, cuja satisfação encontravase a seu encargo. Parte do sonho materno pode ser realizado - a festa dos 15 anos, mas a outra parte, que alude à escolha do objeto amoroso fora do círculo familiar, não pôde ser satisfeita.

\section{$O$ despertar da feminilidade}

Para Ana Júlia, a menarca foi vivenciada com sentimentos de vergonha, desconforto e estranhamento, decorrentes de uma sensação nova por precisar usar absorvente e sentir a menstruação - “aquilo” - descer. Sentia que a reação de sua mãe e suas tias era discrepante frente ao que ela mesma estava sentindo, uma vez que todas a abraçaram e beijaram, demonstrando orgulho por ela ter se tornado "mocinha".

Aí eu chamei a minha mãe, eu falei: "Mãe, me empresta um absorvente seu que... que a minha primeira menstruação desceu...", mas morrendo de vergonha da minha mãe... Aí a minha mãe: “Ai, que legal, você já veio a menstruação, que bonitinha, já ficou mocinha...". Aí ela não se contentou, daí teve o outro dia que foi churrasco na minha casa, minhas tias todas lá presentes, ela vai e me fala que eu já era mocinha 
[riso], aí que eu morria de vergonha mesmo, daí minhas tia vinha e abraçava, beijava... E eu falava: "Mas isso não é bom, não sei pra que vocês tão falando isso, porque isso é horrível! ”. (Entrevista com Ana Júlia)

Ana Júlia não soube descrever os motivos que a faziam tomar a menstruação como algo “horrível”. Além disso, o conteúdo manifesto no relato da participante era bastante divergente da forma como ela se expressava: ao mesmo tempo em que falava do horror à menarca, contava do orgulho da mãe e das tias dando risadas. Ou seja, a forma de Ana Júlia se expressar parecia dissociada do conteúdo e dos sentimentos negativos provenientes da experiência da primeira menstruação. Segundo Pec, Bob e Raboch (2014), a dissociação pode ser definida como uma fragmentação da experiência consciente, que está tipicamente relacionada ao estresse agudo e/ou de longo prazo, que perturba de forma significativa o autoconceito, a identidade, a memória e a percepção do mundo externo. Nesse sentido, podese pensar que Ana Júlia trata do tema da menarca com certo distanciamento emocional, quase no limite do desinvestimento afetivo, provavelmente por se tratar de um tema que envolve intensas emoções e que ameaça seu sentimento de integridade, traduzindo seu desconforto com a feminilidade.

Acredita-se que o estranhamento relatado pela participante não se restringe apenas às sensações físicas da primeira menstruação, mas também à percepção inconsciente do processo de amadurecimento, de “tá passando de menina para moça, de tá virando mulher”, deixando de ser criança e, portanto, separando-se inevitavelmente da mãe. Para McDougall (1997), a sexualidade humana é inerentemente traumática, devido aos conflitos psíquicos gerados pelo choque entre o mundo interno de pulsões primitivas e as forças repressivas do mundo externo. A noção de um self separado do objeto de amor - o "seio-universo" da mãe - é acompanhada de uma forma primitiva de depressão, que emerge a partir da frustração e da fúria pela perda desse objeto. O devir da feminilidade implica, portanto, na elaboração do luto pela perda do objeto primordial do qual, para Ana Júlia, é impossível separar-se. 
Antônia descreveu a menarca da filha de forma emocionalmente distanciada, dizendo apenas que foi "legal" e que, no dia em que aconteceu, levou-a para comprar "o que precisava”. A posterior interrupção da menstruação (amenorreia) em decorrência do TA foi nomeada pela mãe de “decepção”, e parece ter sido algo que, para ela, permaneceu mais marcado do que a própria menarca.

Pra mim foi uma decepção, né. Porque aí eu pensei: “Mas, como?”, eu nunca tive, eu menstruei com nove anos e até hoje, eu nunca tive isso de ficar um mês, dois meses sem menstruar, e ela ficou, aí eu falei: "Não é normal, vou procurar um médico pra saber, né?” Aí o médico falou, ela já tava com 15 anos, falou que tudo era porque ela era muito magrinha, muito sem peso, muito sem quilo. [...] (Entrevista com Antônia)

Assim, o estranhamento quanto à alteração do ciclo menstrual da filha sobrepôs-se à percepção de que poderia ser um indicador de uma problemática maior, que a levava ao estado de grave desnutrição, que a mãe se negava a ver. A segunda decepção descrita por Antônia foi “o namoro que não deu certo”.

Então, aí depois dos 15 anos que ela parou de menstruar por uns meses, veio a decepção do namoro que não deu certo, do que ela queria fazer que não deu certo, $e$ ela já foi diminuindo a comida [...] (Entrevista com Antônia)

O trecho acima, recortado da entrevista de Antônia, remete ao questionamento: a decepção advém do que Ana Júlia queria fazer e não deu certo, ou do que a mãe esperava que acontecesse na vida da filha, e que se frustrou? Ao descrever seu namoro com o atual marido, Antônia relatou: “Foi muito bom, foi legal, e eu me preocupava porque ele morava em R. e eu morava em B., aí: “Ah porque tal dia ele vem”, aí arruma cabelo, arruma unha, fica bonita, escolhe roupa e onde a gente vai, era legal”. Logo em seguida, ao ser questionada a respeito do desejo de que Ana Júlia tivesse um namorado, Antônia respondeu: "Ela não é namoradeira, ela é assim, ficou só naquilo e pronto, mas seria legal se ela arrumasse um namorado... “Ai, mãe, hoje eu vou sair. Mãe, que roupa que eu ponho, tá bom assim, sabe?”. 
Percebe-se que há o desejo manifesto, por parte da mãe, de que a filha passe pelas mesmas experiências que ela, e também de ela poder ser a mãe presente em um momento especial da vida da filha, compartilhando sua satisfação de ter o acalentado príncipe. Desse modo, os ideais da mãe parecem estar fundidos aos da filha.

Para Cido, a chegada da menarca de Ana Júlia foi considerada “normal”, associada com boa saúde. Tratava-se de um dos assuntos que eram conversados apenas entre a mãe e as filhas, assim como os correlatos: sexo, namoro, uso de anticoncepcional, entre outros “assuntos de mulher”.

Ah, são assuntos, esses assuntos mesmo que você sabe. Sabe... Às vezes... Igual... Tem a outra irmã dela, que é mais nova, então ela toma anticoncepcional, mas isso aí, é... Isso aí ela toma porque ela foi medicada, que ela teve que fazer exame, a mãe dela sempre leva... Ela não teve nenhum problema que a minha esposa poderia passar, a única coisa que eu achei estranho... Eu falei: "Mas tá tomando anticoncepcional? Mas não tem nem namorado, pra que isso?", aí: "Não, ela toma...”, porque eu não sabia, eu não acompanhei, eu não fui no médico pra saber como é que é, ela falou: "Não, é porque ela sente cólica demais, ela teve problema, então teve que tomar”, eu falei: “Tá bom, então tá ótimo! Então, não é o que eu tô pensando? Não é!” [riso]. (Entrevista com Cido)

Nota-se que o pai apresenta dificuldade para nomear os assuntos que, em sua opinião, não são da alçada do genitor masculino, referindo-se a eles como "esses assuntos mesmo que você sabe”. Além disso, as reticências excessivas podem ser consideradas indícios de dificuldades para relatar questões a respeito da feminilidade das filhas - no caso, o uso de anticoncepcional e a possibilidade da filha vir a manter relações sexuais. Essas questões ficam evidenciadas em um trecho do diário de campo da pesquisadora:

Durante a entrevista, Cido se mostrou sorridente e disposto a participar. Ao contrário do que a esposa havia previsto, Cido foi bastante participativo e não se negou a responder nenhuma das questões. No entanto, foi possível notar certa dificuldade, embaraço e por vezes constrangimento para discorrer sobre as questões relativas à sexualidade da filha e à sua própria, uma vez que o participante respondia às questões de forma evasiva, introduzindo outros assuntos que escapavam do que estava sendo questionado. [...] Enquanto o participante falava, várias vezes tive a sensação de que ele parecia desconectado da filha, do que acontecia com ela, seu mundo 
interno, tanto em relação ao transtorno alimentar quanto a outros aspectos do desenvolvimento. O relato me suscitava a sensação de que o pai foi pego de surpresa pelo emagrecimento da filha, e que desde então tem procurado participar assiduamente do grupo de apoio psicológico aos familiares oferecido pelo serviço como forma de se aproximar da filha e tentar compreender o que se passa com ela. Eu sentia como se o pai atribuísse à mãe o papel de cuidar das filhas, enquanto que seu papel era de ser o provedor material da casa e de "zelador", embora distante, da preservação de sua virgindade. (Diário de campo, entrevista com Cido)

\section{Relacionamentos afetivos e vida sexual}

Ana Júlia confidenciou que nunca manteve um relacionamento afetivo a longo prazo, tendo tido apenas três envolvimentos até o momento da entrevista. O primeiro relacionamento, que a participante denomina “meu primeiro amor”, trata-se do colega de sala de aula por quem se apaixonou aos 13 anos de idade, o mesmo jovem a quem os pais se referiram quando mencionaram a decepção amorosa que a filha sofreu na adolescência. A participante relatou que foi apaixonada por esse jovem durante cinco anos, mas nunca chegaram a namorar devido ao fato de que ele não queria se relacionar de forma séria, alegando que desejava se relacionar com outras meninas.

Depois de acalentar por tanto tempo esse amor platônico, o segundo envolvimento afetivo foi com outro colega de sala, dessa vez do curso de auxiliar técnico, aos 22 anos de idade. Ana Júlia narrou um acontecimento bastante marcante em sua vida afetiva: após três meses se relacionando com o garoto no curso, a participante decidiu passar a noite com ele e, para tanto, precisou mentir para a mãe, dizendo que dormiria na casa de uma amiga.

Aí eu acabei mentindo pra minha mãe que eu ia dormir na casa de uma amiga minha, só que eu fui dormir na casa dele, e eu achei que ele era, do jeito que ele era comigo, assim, preocupado, carinhoso, e tal... Do jeito que ele era comigo na escola, assim, quando a gente se via, e chegou na hora [de manterem relação sexual pela primeira vez] não foi nada daquilo. Eu queria dormir mesmo abraçada com ele e tal, e ele me forçou a fazer as coisas que eu não queria fazer, né, então dali ele fez tudo que ele tinha que fazer, porque tava só nós dois em casa. E me magoou demais isso, eu às vezes me sinto culpada por isso ter acontecido. Daí eu tive esse namorinho, daí eu larguei dele e tal, e depois no ano passado eu tive um também, um namorinho. (Entrevista com Ana Júlia) 
Logo após essa narrativa, Ana Júlia começou a contar do terceiro relacionamento, porém de forma muito breve, pois foi um “namorinho” passageiro, que durou apenas três semanas. A pesquisadora sentiu-se chocada com a história sobre o garoto do curso técnico, cogitando a possibilidade de a participante ter sofrido um abuso sexual. Pode-se considerar que o choque vivenciado contratransferencialmente pela pesquisadora foi análogo ao choque que Ana Júlia provavelmente sentiu no momento, embora não tenha se dado conta disso, já que, mais uma vez, narrou o acontecimento de forma dissociada, emendando uma história na outra e sem expressar aparentemente qualquer tipo de sofrimento.

Durante a entrevista, Ana Júlia mencionou a vivência de um possível abuso sexual, e o relato dessa experiência fez sentido com o que eu senti contratransferencialmente: senti que estava invadindo sua privacidade, fazendo perguntas muito íntimas, e que ela se protegia por meio da postura física rígida e das respostas que, muitas vezes, pareciam se esquivar das minhas perguntas. No momento em que a participante narrou esse acontecimento - em um relato que parece embebido em fantasias -, senti um choque muito forte e permaneci perplexa por alguns segundos ouvindo a história. Pela forma distanciada e desprovida de afeto como a participante narrou o acontecimento traumático, pensei que eu estava sentindo o choque que ela não conseguira elaborar, talvez pelo sexo ainda ser uma experiência desconhecida para ela e, como tal, assustadora. (Diário de campo, entrevista com Ana Júlia)

No entanto, após a releitura da transcrição da entrevista, a pesquisadora vivenciou uma impressão de que Ana Júlia havia permanecido passiva na relação sexual, congelada pela intensidade dos sentimentos aflorados, sem poder expressar o desejo de que o jovem fosse carinhoso, ou mesmo o desejo de interromper o ato sexual. Pode-se pensar que a participante ainda se sentia como aquela menina de 15 anos, que esperava viver um conto de fadas com seu “príncipe”, mas foi tratada como uma adulta, ou nem isso, como um objeto de prazer fácil e imediato. A pesquisadora sentiu como se a participante não houvesse compreendido perfeitamente o que havia lhe acontecendo no momento da relação sexual, uma vez que sua descrição implica o intercurso como algo que envolve aspectos muito primitivos e 
“animalescos” do ser humano, contrários ao que Ana Júlia esperava da noite que passou com o rapaz.

Não, eu achei que ia acontecer a relação sim, mas não do jeito que ele... Bom, sempre ele me apresentou ser um cara, assim, respeitador e tal, quando eu falava "não" na sala de aula, ou em algum lugar que a gente tava perto, ele respeitava, e tal... E chegou no dia, eu falei: "Então a gente vai ter uma relação", mas só que eu achei que ia ser todo carinhoso, todo com jeito e tal, e na hora não foi nada disso, foi totalmente monstruoso. (Entrevista com Ana Júlia)

Ana Júlia parece ter presenciado sua realidade fantasiosa se quebrar, e vivenciou a realidade como uma tragédia, algo “monstruoso” e permeado por muita dor e humilhação, e que era difícil “digerir”. Vivia uma realidade infantilizada, na qual o sexo era motivo de vergonha, assim como beijar em público: "De beijar também, às vezes tinha que assim, a gente conversando assim e ele chegava pra me dar um beijo, assim, na frente do intervalo inteiro, então eu morria de vergonha e daí eu ficava com as bochechas, assim, ardendo de vergonha e já ia pro banheiro”. Tratava-se de uma realidade estranha, pois se sentia até então protegida, dependente do cuidado alheio, pois ainda era a menina cuidada pelos pais e irmãos (cinco irmãos!), a “porcelana” que pode se trincar ou quebrar sob pressão.

[...] Notei que ela me fitava com olhos grandes, quase arregalados, e quando me olhava eu tinha a sensação de que se sentia muito amedrontada. Em contrapartida, mostrava firmeza na forma de falar, seu discurso não era reticente. Notei uma incompatibilidade entre essa firmeza na fala e o físico esmaecido, como se houvesse uma luta interna entre a força necessária para crescer e se diferenciar e a tenacidade com que se agarrava a um persistente processo de infantilização. (Diário de campo, entrevista com Ana Júlia)

A vergonha e o sentimento de culpa que envolvem o ato sexual, descritos por Ana Júlia, podem ser caracterizados como respostas ao paradoxo entre o desejo de se separar da mãe versus a devoção e dependência da filha em relação a ela. O acontecimento com o garoto do curso técnico nunca foi compartilhado com ninguém, nem mesmo com os pais ou com a melhor amiga. O fato de ter mentido para a mãe sobre dormir na casa da amiga parece ter 
intensificado o sofrimento (derivada da culpa, pois se oferecera sexualmente) da noite que passou com esse garoto, pois além da frustração da expectativa que tinha daquela noite, Ana Júlia também sentiu que decepcionou os pais.

Ai, é horrível, porque às vezes o meu pai e minha mãe me põem assim lá em cima, porque eu tô sendo guerreira de tá aqui tendo acompanhamento, pedindo ajuda, e eles tá participando mais, assim, observando a alimentação, então eles falam: "Ai Ana Júlia, você tá superando cada dia mais o que você, o que a gente achou que não ia dar pra você superar". [...] E o meu pai e minha mãe dá mó força agora, fala: "Ai, cê tá aqui em cima, e tal, tá se superando", e na hora que eles falam isso de mim, me elogia e tal, eu fico pensando ainda na história de: "Poxa, eu menti, tá certo que foi uma vez só, mas eu menti por uma coisa que eu achei que ia ser tão boa pra mim, $e$ acabou sendo desastrosa”. E eu não consigo falar, aí eu fico chateada comigo por ter mentido pra eles e eles achar que eu sou uma pessoa, assim, guerreira, lutadora, cada dia mais, e eu ter na cabeça aquele negócio de ter mentido pra eles. (Entrevista com Ana Júlia)

A relação sexual parece ter sido duplamente decepcionante: por um lado, Ana Júlia sentiu-se desapontada por não ter vivido o sexo da forma como esperava e, por outro lado, sentiu que decepcionou os pais por haver contado uma mentira sobre a noite que passou com o garoto. No entanto, pode-se pensar na possibilidade de que o sentimento de haver decepcionado os pais relaciona-se não apenas com o fato de haver omitido uma parte tão impactante de sua vida íntima, mas principalmente de se tratar de algo que aconteceu - ou foi vivenciado pela participante - de forma animalesca e "grosseira", diferentemente do conto de fadas que a mãe esperava que a filha vivesse. Dessa maneira, os ideais maternos foram mais uma vez contrariados, com o agravante de que agora havia sido por escolha da filha, diferentemente da primeira decepção, causada pela recusa do garoto de assumir o lugar de "príncipe” que lhe fora outorgado.

No que concerne à primeira relação sexual, Ana Júlia confidenciou que sua primeira vez havia se dado quando tinha 15 anos de idade, com o "príncipe”, o garoto da escola que fora seu “primeiro amor”. 
Foi com aquele menino da sétima série que eu era apaixonada, eu fiquei apaixonada por ele uns três, quatro anos, não me lembro mais... E era amigo meu e ele me passava, assim, total segurança, assim, parecia que ele gostava... parecia não, ele gostava de mim, assim... Mas não pra ser a namorada dele assim fixa, porque ele gostava de beijar outras meninas. Então, como eu tava tão apaixonada por ele, eu falei que a minha primeira vez ia ser com ele, e eu contei pra ele, morrendo de vergonha, mas eu contei. [...] Porque eu gostava tanto, eu gostava, amava tanto ele que eu queria que a minha primeira vez fosse com ele, e eu sempre, é assim, nos filmes, novela, livro... Fala que a primeira vez tem que ser com um cara que você realmente ama, então por ele eu suspirava, assim, e o coração já doía de tanto pensar nele, eu ficava 24 horas pensando nele, e daí eu contei pra ele que eu queria que a minha primeira vez fosse com ele. [...] Aí eu falei: "É porque eu quero mesmo, porque eu amo você, então tem que ser com você, porque se não depois eu não sei se eu vou amar outra pessoa do jeito que eu te amo.” (Entrevista com Ana Júlia)

Esse excerto de fala mostra a relação de continuidade que a participante estabelece entre sua vida e as narrativas de ficção, tais como filmes, novelas e livros que consome. Evidencia-se, novamente, a vivência de uma realidade fantasiosa, idealizada, que se aproxima dos contos de fadas, com direito a suspiros e coração disparado. É possível hipotetizar que o episódio depressivo apresentado por Ana Júlia dois anos antes da época da entrevista, durante o qual a participante passava a maior parte do tempo fechada em seu quarto, relacionava-se com uma tentativa de fugir dos traumas vividos, além do desejo de escapar da dor da realidade e das tragédias às quais todos os seres humanos estão suscetíveis de sofrer. O quarto, a casa, a família e o paredão de irmãos pareciam configurar um espaço de acolhimento, no qual Ana Júlia sentia-se segura e protegida de todos os perigos da realidade. Consequentemente, o crescimento e a entrada na vida adulta parecem ser vivenciados com muito sofrimento, sendo negados por meio da sintomatologia insólita do TA que, de quebra, mantém a preocupação e os cuidados recebidos dos familiares -, mas levando a participante a permanecer fixada em etapas iniciais do desenvolvimento psicossexual.

Antônia considerava-se “um livro aberto para todos escreverem e lerem”, ou seja, sempre esteve disposta a conversar com os filhos sobre o que quisessem, inclusive sobre relacionamentos afetivos. Contou que não soube quando Ana Júlia começou a se interessar por namoro, mas que costumava dizer: "Se você quiser namorar, ficar, você tem que falar pra 
mãe, não faz nada escondido nem nada que vai te magoar depois”. Essa frase, vista pelo olhar crítico da pesquisadora, adquire um insuspeitado poder de profecia auto realizadora. Tal qual a maldição emitida por uma feiticeira de conto de fadas, a sentença acabou se convertendo em realidade e o que aparece como temor na narrativa materna termina por se materializar na vida da filha. Desde cedo Ana Júlia parece ter internalizado que não poderia esconder nada de sua mãe, no que se refere à sua intimidade sexual, o que pode estar relacionado com o agravamento do seu sentimento de culpa pelo segredo que guardava a sete chaves: a noite que passou com o jovem do curso técnico. Nota-se que a mãe procurava aconselhar a filha com o intuito de evitar as consequências não desejadas, como o risco de uma gravidez não planejada, buscando resguardar o bem-estar da filha. Nessa vertente, alguns valores sociais parecem ter sido transmitidos de mãe para filha:

Pra prevenir, né, porque tem muitas meninas que com 10 anos já tão grávidas, não é legal ficar dormindo com um, dormindo com outro assim, tendo relação com qualquer um, não é legal isso, não é legal, eu não acho. Desde que o mundo é mundo, eu nunca aceitei esse negócio de ficar. "Aí hoje tô namorando um”, sai com um hoje, depois sai com outro, esse negócio de ficar... Ficar, primeiro tem que ir pra motel, primeiro tem que ir conhecer a pessoa, pra depois namorar direito... Não, o certo não é isso. (Entrevista com Antônia)

Evidencia-se, portanto, que Antônia provavelmente não concordaria com a atitude da filha de passar a noite na casa do garoto com quem estava se relacionando, especialmente devido ao fato de eles não haviam consolidado uma relação de namoro. Nesse sentido, a angústia vivenciada por Ana Júlia naquela noite parece ter sido intensificada pela voz acusadora da “mãe interna” (Klein, 1934/1981), indicando que sua atitude “não era legal” e que ela rompera com o pacto de ouvir a mãe e, sobretudo, “dizer tudo" à mãe ("você tem que falar pra mãe, não faz nada escondido nem nada”).

O relato do pai se assemelha ao de Antônia no que diz respeito à consideração acerca da possibilidade das filhas manterem relações sexuais antes do casamento. No entanto, relatou 
que não tinha o hábito de conversar sobre esse assunto, principalmente pelo fato de não ter estado presente durante a infância das filhas.

Ah, a gente conversa assim, meio... Meio cabeça baixa, né? É difícil encarar de frente, assim sabe, igual eu tô conversando com você, não dá pra encarar, você fala meio com a cabeça baixa, meio assim. [...] Talvez o receio, porque você não acompanhou desde o início, né? Então, agora... Você tinha que ter pegado nos 10 anos, aí você junto com a mãe, sabe? Aquilo lá. Então, como você já pegou ela já praticamente mocinha, que a mãe dela veio falar da primeira menstruação, já tava praticamente moça... Então, você tem aquele receio de ficar falando [...] Porque, igual eu comentei com você, eu não vi meus filhos crescerem, né? Eu trabalhava, chegava em casa só à noite, 10 horas, saía três, quatro horas da manhã... Chegava 10 horas da noite, então não tinha tempo pra isso. (Entrevista com Cido)

Quando questionado a respeito da vida sexual de Ana Júlia, Cido relatou que desconhece esse aspecto da vida da filha, e que sua percepção é de que ela nunca teve relações sexuais. Atribuiu isso ao fato de vir de família humilde, na qual não havia diálogo, e também ao fato da esposa ser "reprimida" para conversar sobre "esses casos". Relatou que sua “desenvoltura ficou bem a desejar”, referindo-se a seu papel de pai, principalmente pelo fato de não ter tido uma figura paterna em sua vida.

Então, por isso que hoje a minha desenvoltura ficou bem a desejar. [...] Eu não falo as dificuldades que eu tive de criança com o pai, de não ganhar um presente, sabe, não poder contar com ele pra nada, sabe? Nem pedir um doce, uma bala, sabe. Ele me largou e a minha mãe quando eu tava com um ano e oito meses. [...] Ele é separado, até hoje, são separados. Eu... até domingo agora eu fui visitar ele, que ele tá doente, né? [...] Aí eu fui lá na casa de uma irmã minha por parte de pai, eu fui e visitei ele e tudo, cumprimentei... porque... eu tinha ficado com raiva dele... Eu conheci ele, eu tava com 35 anos, aí quando foi daí uns dois, três anos mais ou menos, ele arrumou uma menina de 16 anos e arrumou um filho com ela. E através, quando ele veio me comunicar essa situação, eu apelei com ele, né? Apelei, assim, que eu falei pra ele: "Cê arruma uma mulher dessa idade aí e que futuro você tem pra dar pra essa criança?” (Entrevista com Cido)

Nota-se que Cido se sentia prejudicado por não ter tido um pai, principalmente pelo fato de que não pôde internalizar um modelo paterno que lhe possibilitasse ser um pai adequado para seus filhos. Nota-se que, da mesma forma que a maternidade coloca a mãe 
frente a frente com questões edípicas muito arcaicas de sua constituição subjetiva (Soifer, 1980), também a paternidade força o pai a entrar em contato com a maneira como seus próprios pais foram internalizados. Ou seja, pode-se considerar que a forma como o pai irá experienciar a paternidade depende da relação estabelecida com os pais introjetados (Klein, 1934/1981). Nesse sentido, examinar as relações objetais do casal parental pode proporcionar um conhecimento valioso para que se compreenda suas limitações, assim como suas potencialidades, como pais. Isso porque, em certa medida, o desempenho das funções parentais está condicionado pelos modelos interiorizados.

Vale ressaltar que tanto Antônia quanto Cido apresentaram dificuldades para falar de sua própria vida sexual e afetiva, uma vez que as perguntas que abordavam esses temas eram respondidas de forma evasiva, monossilábica e reticente, evidenciando resistências e negações inconscientes acerca da sexualidade, que provavelmente é tomada como um tabu.

No final da entrevista, a participante relatou que o marido muito provavelmente não aceitaria participar da pesquisa, pois não iria responder "àquelas perguntas”, referindo-se às questões sobre sexualidade - sua e da filha. Argumentei que ele poderia ficar à vontade para responder da forma que se sentisse mais confortável, $e$ que eu explicaria isso a ele. Essa fala me fez pensar no quanto a própria participante se sentiu desconfortável com as perguntas sobre sexualidade, e no quanto era difícil para ela mesma pensar em si mesma enquanto mulher. (Diário de campo, entrevista com Antônia)

Ana Júlia apresenta dificuldade de se envolver amorosamente e confiar na possibilidade de estabelecer um vínculo duradouro com um parceiro. Contudo, está longe de ter consciência de que seu anseio por um relacionamento de proximidade e confiança com um rapaz se dá em bases completamente idealizadas e, portanto, suas tentativas são vulneráveis a rupturas. O rompimento de vínculos, por sua vez, a precipitam na sensação de inexistência.

Em Sobre o narcisismo: uma introdução, Freud (1976/1914) considera um relacionamento afetivo satisfatório quando existe equilíbrio no montante de energia libidinal que os parceiros investem em sim mesmo e no outro. Quando a libido objetal supera a energia 
investida no ego há um empobrecimento do eu em detrimento do outro. No vínculo idealizado, a pessoa atribui ao ser amado a condição de ter todos os atributos que ela admira e que sente lhe faltarem. O objeto é permanentemente enaltecido. É como se a outra pessoa fosse um sol, do qual dependesse para iluminar sua vida opaca, pois se vê como um planeta apagado, sem luz própria, a depender da luz que recebe do ser amado para sobreviver psiquicamente. Em contraposição, quando o vínculo é baseado em uma percepção não idealizada, há espaço para uma percepção da existência real do outro, que não é percebido como mero prolongamento do eu, mas um ser dotado de desejos próprios e limitações. Desse modo, há possibilidade de trocas genuínas, mas é preciso se contentar com as gratificações possíveis e suportar as frustrações inerentes ao relacionamento.

A mãe de Ana Júlia afirma que tenta se apresentar à filha como uma pessoa que têm seus limites e que, portanto, não está longe de ser infalível. Contudo, é pouco provável que se apresente realmente por seus limites, falhas e imperfeições. Quando se vive uma relação extremamente idealizada, o perigo é confundirem-se uma com a outra, o que faz com que a filha vá progressivamente se anulando e se transformando em uma sombra do objeto materno enaltecido. Assim, para não perder sua tão desejada perfeição, se perde de si, seu amor próprio, sua autoestima e sua autoconfiança. Tanta idealização, no limite, pode despertar sua inveja, fazendo com que a natureza idealizada do vínculo se torne hostil. Mãe e filha não se dão conta dessa dinâmica relacional intoxicante. 


\subsubsection{Família Paiva}

Flávia, a filha: “A B. é uma bonequinha, é uma princesa. Eu sou a fera... Não sei o que eu sou."

Márcia, a mãe: "Ela é muito diferente, ela fugiu da regra. Da minha regra, do que eu sou, do que eu aprendi, do que eu acho certo.”

José, o pai: "Porque, quando mais novo, eu sempre fui muito mulherengo, mesmo, sempre."

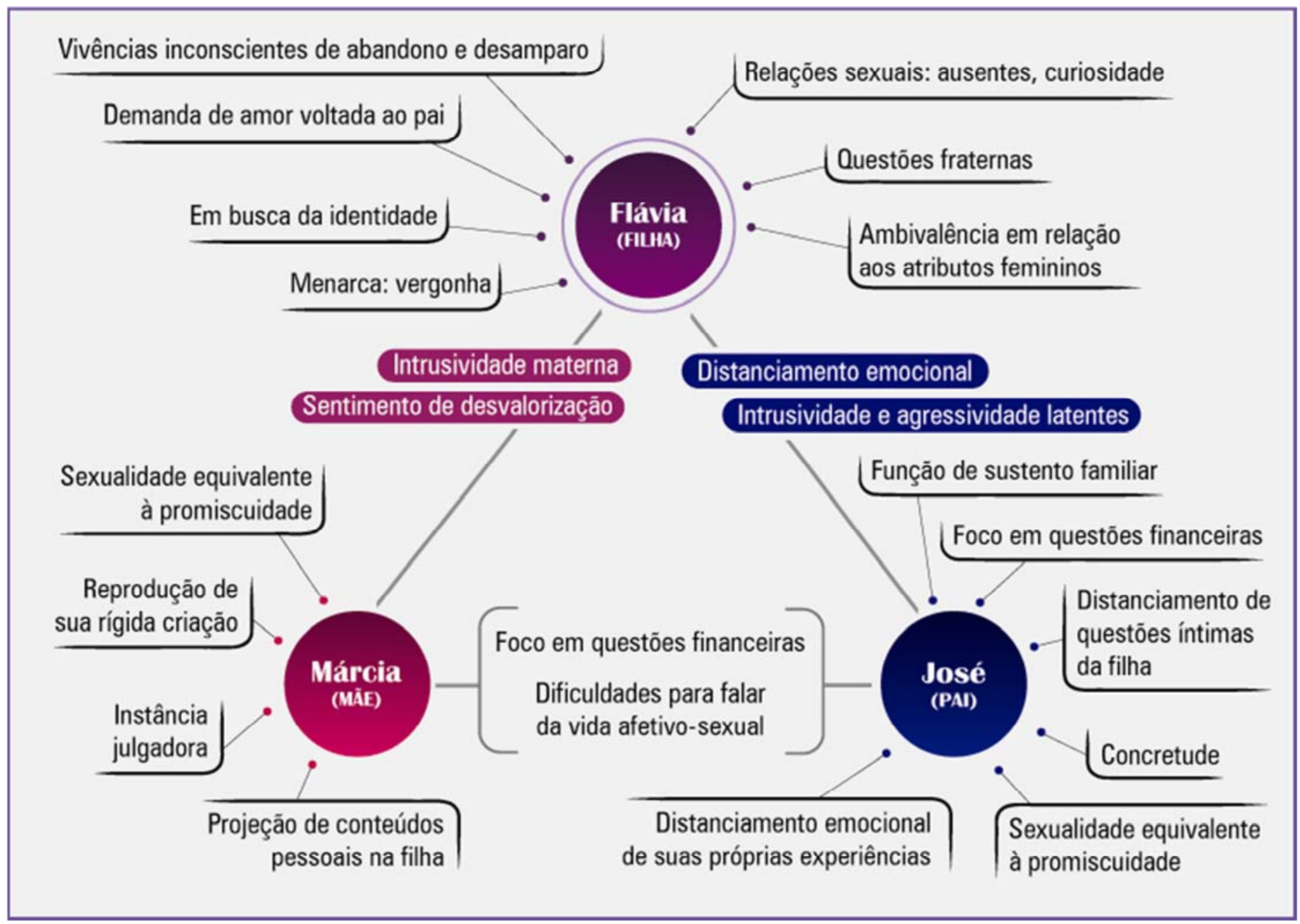

Figura 3. Mapa de associação de ideias da família Paiva. 
Flávia iniciou o tratamento no GRATA no ano de 2012, quando tinha 15 anos de idade, após apresentar emagrecimento, pois havia perdido cinco quilos em dois meses. Apesar de não se tratar de uma perda significativa do ponto de vista clínico, a participante apresentava distorção grave da imagem corporal, insatisfação com o peso e referia ter fome, porém sentia nojo ao mastigar os alimentos. Também realizava rituais purgativos diários, incluindo vômitos e uso abusivo de laxantes. Foi diagnosticada com AN do tipo purgativo, com peso de 43,3 kg, altura de 1,58 m e IMC = 17,3 kg/m², considerado abaixo do ideal para a idade e altura da participante. Também foram evidenciados traços de transtorno de personalidade borderline, ainda que esse diagnóstico não pudesse ser estabelecido devido à idade da participante.

Na época da realização da entrevista, Flávia tinha 17 anos e fazia tratamento no GRATA havia, aproximadamente, dois anos. Pesava 53,1 kg e tinha IMC $=21,8 \mathrm{~kg} / \mathrm{m}^{2}$. O diagnóstico de AN do tipo purgativo estava sendo revisto pela equipe multiprofissional, uma vez que a participante já não referia desejo de perder peso e também não apresentava períodos de restrição e purgação alimentar. No entanto, queixas relacionadas à imagem corporal ainda eram evidentes nos relatos de Flávia, que referia o desejo de ganhar massa muscular e buscava realizá-lo por meio de dietas bastante seletivas e da realização diária de atividade física (musculação) frenética.

[...] Assustei-me quando ela chegou: esperava vê-la bastante emagrecida, de forma condizente com seu diagnóstico de AN do tipo purgativo. Entretanto, a jovem que se apresentou a mim era fisicamente forte, com ombros largos, braços musculosos e pernas grossas. Vestia-se com calça jeans e blusa branca, ambas bastante justas, deixando os músculos à mostra. Sentava-se encurvada, evitava o contato visual direto comigo, observando-me apenas com o canto dos olhos, como se estivesse com medo. (Diário de Campo, entrevista com Flávia)

Em relação à configuração familiar, Flávia tinha uma irmã gêmea univitelina e um irmão de 14 anos de idade, e os três eram estudantes de escola particular. A mãe tinha 52 anos 
e era advogada. O pai tinha a mesma idade que a esposa e era empresário. Ambos tinham curso superior completo. Na residência moravam os cinco membros da família, e a renda relatada pelo pai era de aproximadamente $10.000,00$ reais. Segundo o resultado da pontuação no CCEB/2015, a família se encaixava no estrato socioeconômico B1.

\section{O transtorno alimentar}

A insatisfação com o corpo esteve presente na vida de Flávia desde os 15 anos de idade, quando sentiu necessidade de perder peso e passou a restringir a alimentação, contar calorias e realizar rituais purgativos que incluíam vômitos e uso de laxantes. No momento da entrevista, a insatisfação continuava presente, ainda que com uma apresentação diferente: Flávia havia passado a desejar o ganho de massa muscular e o aumento de massa magra. A comparação com a irmã e o consequente sentimento de inferioridade em relação a ela também emergiram no relato como fontes de insatisfação.

[...] no começo desse ano eu comecei a ir pra outro lado, tipo comecei a querer ficar maior, com mais músculo, sei lá achava: "Nossa, como minha perna tá fina, nossa eu não tenho seio" e aí eu ficava olhando... E minha irmã tem muito seio e eu ficava: "Por quê que ela tem?". Ela tem muito, tipo muito. E todo mundo, tipo passava um homem do lado dela muito bonito e ele ficava olhando e eu ficava... Queria tá tipo a B. [irmã]... Nossa, eu queria ter seio, queria colocar silicone, né. [...] (Entrevista com Flávia)

Para Flávia, a autocobrança em relação ao seu desempenho no balé foi um dos fatores que culminaram no desenvolvimento do TA. Sentia que "estava se destruindo" ao buscar o destaque desejado, que implicava em ter um corpo "palito". No entanto, suas próprias comparações com a irmã também emergiram como possíveis fatores precipitantes do quadro: a irmã surgiu inúmeras vezes nos relatos de Flávia como alguém mais favorecida em termos físicos e de personalidade. Nota-se, portanto, que a insatisfação de Flávia vai além do corpo: 
há uma vivência persistente de inferioridade, como se irmã fosse melhor, chamasse mais atenção das pessoas pelas qualidades, que extrapolavam os aspectos físicos.

Ah... Eu acho que até hoje eu fico, parece que ela, sabe... Assim, ela é branquinha, ela é loira e tem olho azul e ela se desenvolveu bem antes que eu. E ela sempre teve o corpo maior que o meu, né, e aí tipo... antes eu não tinha percebido que era por causa do corpo que os meninos gostavam mais dela, né. Aí depois que eu fui percebendo, que eu vi que eu precisava ser... Sei lá, mais bonita, mudar meu corpo, alguma coisa assim, sabe. Eu não sei se é por isso que eu mudei. Agora, por exemplo, eu não tento mudar, pros outros, pra eles me verem, sabe, só sei que, quando alguém deles me critica, eu fico... Eu não gosto. (Entrevista com Flávia)

Para Márcia, os sintomas de TA da filha alternavam entre momentos de restrição e compulsão alimentar, pois ao mesmo tempo em que ela tinha medo de engordar e restringia drasticamente a alimentação, também apresentava momentos de fome intensa, seguida da ingestão demasiada de alimentos: “[...] ela tá com muita fome, então ela come muito, toma uma garrafa de café e, se deixar, se não ficar chamando a atenção, se ela tiver sozinha, ela come seis bisnaguinhas, ela come tudo o que ela ver que ela gosta [...]”.

Ao ser questionada acerca do início dos sintomas de TA da filha, Márcia relatou que Flávia "sempre foi uma menina de temperamento muito difícil”, ou seja, desde a infância era preciso que os pais “chamassem mais a atenção” de Flávia do que dos outros dois filhos. Observa-se, no relato materno, que a participante atribuía a precipitação do quadro a aspectos de personalidade da filha, que se diferenciavam dos outros filhos, que não apresentavam maiores dificuldades no processo adaptativo e, muito menos, um quadro psicopatológico.

Ahhh, era... Brigava muito, reclamava muito, não sabe dividir as coisas... Impõe muito, então eu tinha sempre que estar mediando as coisas, eu e meu marido, né, então muitas vezes não aceita, não aceitava que a gente falava, chamava a atenção... Ela nunca foi de obedecer, ela sempre foi muito contestadora, né, então muitas vezes o meu marido tinha que chamar a atenção e acho que, com 16 anos, se ela apanhou umas três vezes foi muito. Então, a gente achava que era por isso. [...] (Entrevista com Márcia) 
José, por sua vez, relatou que Flávia já não mais apresentava dificuldades com a alimentação, exceto pelos rígidos critérios no momento de selecionar o que vai comer: “quer ficar bombada", e por isso "come praticamente quase tudo", mas é bastante exigente nos tipos de alimentos que ingere, privilegiando alimentos construtores. Ao buscar compreender possíveis vivências associadas ao despertar do TA da filha, José pontuou uma contradição entre a valorização do visual pela filha e sua negligência com a higiene pessoal.

[...] e hoje a gente vê que ela tem essa questão de valorizar bastante o visual dela. Só que... é estranho porque... ela não toma banho. A gente tem que ficar falando: "Flávia, vai tomar banho." Às vezes ela entra no carro e a gente fala: "Você tá cheirando suor!", ela entra no banheiro, fica uma hora no banheiro e não toma banho. Então, tem dia que eu falo: "Flávia, não é possível isso, você ficou no banheiro, você tá cheirando suor, você não tomou banho!" [...] Escovar dente, ela não escova os dentes. Então toma o café da manhã e vai pra escola sem escovar dente. E não adianta, né, a gente fala, insiste: “Ô, Flávia, é assim, ó, você tá vendo?" Tive que levar ela em dentista, fazer tratamento de canal, obturação, agora tem que voltar novamente. [...] (Entrevista com José)

O relato do pai mostrou convergências com o da mãe no que concerne aos aspectos de personalidade da filha, que este considerava como "agressiva, não dava liberdade para falar”. Ou seja, José também apresentava dificuldades para lidar com o “temperamento difícil” de Flávia, diferente da outra filha - B. -, que ambos os pais descreviam como tendo uma personalidade mais maleável, fácil de lidar. Evidencia-se, portanto, a ocorrência de vários conflitos familiares decorrentes da dificuldade dos pais de lidarem com as demandas e necessidades subjetivas de Flávia.

\section{As relações familiares}

Os relatos de José e Márcia apresentaram contradições no que diz respeito à dinâmica familiar: ambos relataram não terem o hábito de “ficar massacrando”, “ficar bisbilhotando” a vida dos filhos, mas, em contrapartida, descreveram várias situações nas quais precisaram conversar com Flávia sobre suas condutas, principalmente em relação a saídas com amigos, 
lugares que frequentava, amizades com meninas “mal faladas” e relacionamentos afetivos, sendo que tais conversas acabavam gerando conflitos e discussões sérias com a filha. Flávia, por sua vez, refere que se sentia presa e invadida pelos pais. Gostaria de ter mais liberdade para poder sair e se relacionar com quem desejasse.

Márcia se mostrou bastante interessada em participar da pesquisa:

Assim que entramos na sala reservada para a realização da entrevista, Márcia disse: "Eu tenho muita coisa para falar sobre a sexualidade da Flávia” e, em outro momento, já durante a entrevista propriamente dita, reforçou o que já havia sido esclarecido a respeito do sigilo: "Isso é uma conversa que vai ficar entre nós, né?" (Diário de Campo, entrevista com Márcia)

Contou várias situações nas quais precisou “bisbilhotar” a vida de Flávia para saber o que ela fazia quando saía com os amigos, incluindo a descoberta inesperada de que a filha havia se relacionado com um vizinho, cujos pais eram conhecidos de sua família. Márcia não conseguiu explicar detalhadamente como soube do relacionamento, mas contou que perguntava frequentemente para B. e para os próprios pais do garoto o que havia acontecido quando Flávia foi até a casa deles. Foi em uma dessas “investigações” que descobriu que a filha havia se trancado no quarto com o garoto.

Ah... Eu acho que foi uma coisa mais superficial, mas eu achei assim, a Flávia é muito precoce nessa parte, porque a Flávia sempre foi quieta e ela... A gente percebe que ela quer sair, ela quer passear, ela quer namorar e a gente nunca proibiu, a gente só queria saber com quem ia, estava, isso é uma coisa natural, né, nós nunca falamos nada, eu estranhei, achei que ela ia demorar um pouco mais, mas eu falei pra ela: "Olha, filha, não pega bem isso pra você", eu e meu marido falamos sem brigar com ela, sabe, sem fazer muito oba oba, a gente falou: "Olha, isso é ruim pra você, ninguém vai falar do rapaz, vai falar de você, a sociedade é assim”. (Entrevista com Márcia)

Com base neste excerto, percebe-se que Márcia apresentava alguns temores relacionados ao despertar da sexualidade da filha, principalmente devido a uma equivalência inconsciente da sexualidade à promiscuidade: ao ser questionada sobre como foi para ela 
saber da real natureza do relacionamento de Flávia com o vizinho, Márcia prontamente associou com a forma como a filha seria vista pelas outras pessoas, o que indica que a preocupação com a preservação das aparências pode ser mais forte do que o propalado interesse pelo bem-estar da filha. Tal equivalência pode ser melhor compreendida ao se observar o relato da mãe acerca de suas próprias experiências:

[...] Eu tenho 52 anos, mas, na minha época, se você entrar no quarto de uma pessoa, principalmente dentro da casa dele, com os pais presentes... Tanto que o pai [do vizinho] achou ruim né, então a gente quis mostrar pra ela que aquilo não era normal pra nós! Então, nossa... Todo mundo falava: fulana não presta, onde já se viu, né, e outra coisa, até hoje é assim e eu vejo que... Eu ouço isso, eu ouço do meu filho de 14 anos: "Mãe, eu não vou ficar com uma moça namoradeira e que fica dando bola pra tudo quanto é amigo meu”, ele tem 14 anos. Pra te falar a verdade, eu tive poucos namorados, me casei com o meu segundo namorado, estou casada há 27 anos né, e meu pai sempre foi uma pessoa muito dura, muito enérgica, então: "Olha, você não faz isso porque isso tá errado, você vai ficar falada, não sei mais o quê”. [...] Era errado ficar até tarde na rua, morar junto com o namorado, não casar, coisas assim... (Entrevista com Márcia)

A rígida educação que Márcia diz ter recebido em sua infância e adolescência parece ter sido reproduzida em sua relação com a filha, assim como conteúdos não elaborados, relacionados a namoro, sexo e condutas femininas diante do sexo oposto. Segundo Borges e Magalhães (2011), entre uma geração e outra se transmite uma realidade, um mundo de hábitos e significados que faziam sentido para a geração anterior. No entanto, a forma como tal realidade é transmitida pela mãe pode, muitas vezes, ser invasiva e devastadora para o psiquismo da filha. Essas vicissitudes podem ser percebidas em Flávia, que demonstrava curiosidade a respeito dos conteúdos que a mãe tratava como tabus, o que fazia com que esta última se sentisse “assustada”. Outra situação relatada por essa mãe na entrevista envolve a descoberta de fotos que a filha havia tirado de si mesma com a câmera digital.

Ao mesmo tempo que ela é muito fina, ela é provocante, também é a sainha bem curtinha, o batom vermelho, é o salto bem alto, ela faz questão de quanto mais curto, melhor, ela gosta de chamar a atenção. Ela gosta de ser sensual, ela é sensual! [...] Se você for na sala a qualquer momento, se ela tá sozinha, ela só assiste filmes de sexo, e 
eu esses dias eu precisei da máquina fotográfica [...] e a dela tava ali em cima na mesa, e eu peguei, né, no que eu peguei e abri eu vi as fotos dela, tava aberta, não fui procurar! Então tinha fotos dela nua, dela... Então ela abria as pernas, abria a vagina e tirava foto... Do bumbum... Tudo bem aberto! E eu falei: "Gente, não sei o que essa menina tá fazendo com essas fotos", a minha preocupação é se alguém pega a máquina! [...] Então ela passava o batom vermelho, isso nas madrugadas em que ela trancava a porta do quarto e ficava... Então, fotos assim, sensuais, nuas, ela tem um monte de fotos, deve ter algum motivo... Eu não sei por que ela faz isso, se é uma forma de extravasar, se é normal, eu não sei o que é normal, né, hoje em dia não sei o que é normal. Acho a palavra normal muito forte, muito esquisita né, mas... Isso tudo me assusta, porque na minha cabeça foge daquilo que eu vivi, entendeu? (Entrevista com Márcia)

Além da tentativa inconsciente de reproduzir os padrões de sua própria criação no exercício da função materna - “Sabe, você faz tudo e a pessoa tá sempre vendo só seu lado ruim, do mesmo jeito que a Flávia acha que eu faço com ela, meu pai fez isso comigo muito [...]” -, Márcia também encontrava dificuldades em perceber a filha como diferente de si mesma, ou seja, de compreendê-la como uma jovem que tinha desejos, curiosidades e hábitos singulares e divergentes dos seus, especialmente no que diz respeito à sexualidade e ao manejo do próprio corpo, seus impulsos e necessidades. Nas narrativas de Márcia é possível notar que ela se manteve comprometida com as regras impostas pelo pai: não teve outros namorados além do marido - que foi a única pessoa com quem manteve relações sexuais -, não saía de casa sem a autorização dos pais, não costumava "ficar até tarde na rua", entre outros aspectos contrastantes com as condutas que percebe na filha. Flávia, por sua vez, tentava de várias formas buscar sua individualidade: ia para lugares diferentes do que havia comunicado aos pais, ficava fora de casa até mais tarde do que os pais permitiam, tentava manter amizades com pessoas de que gostava - ainda que os pais fossem terminantemente contra tais amizades - e, principalmente, sentia intenso desejo de ter relações sexuais.

Ao descrever sua relação com o garoto por quem havia sido apaixonada, Flávia estabelece uma associação entre o sentimento afetivo e a comida e, logo em seguida, entre a “ousadia” sexual e a independência dos pais. 
Ah, não sei, eu queria conhecer ele só. Porque quando eu ficava com ele, eu ficava muito ansiosa, sabe, ficava muito... Ficava muito... E tudo que passava, tipo eu não ficava com vontade de comer, eu ficava com... Eu sei lá, eu ficava com... O meu estômago, ele ficava embrulhado, era uma sensação tipo... Eu não sei... [...] Ah, eu queria ser tipo... Igual ele, sei lá... Queria ser um pouco ousada sabe, tipo queria ser... sabe? Um pouco independente, porque, nossa! O meu vizinho, ele era muito independente, ele tem a minha idade! E eu ficava: "Como é que você sai, assim?”. E eu queria fazer isso também, e aí eu ficava muito, sabe... Sei lá, porque que eu não posso sair assim, por que não?! [...] E eu ficava: "Por quê que eu também não posso sair assim, por que que eu não posso ser mais independente?”. Escolher as coisas que eu gosto de fazer, que eu sinto que os meus pais, principalmente minha mãe, que ela está muito presente, eles me deixam muito presa, sabe? Muito presa... Mesmo quando eles não estão lá, eu quero fazer alguma coisa e eu... não posso. Não sei. (Entrevista com Flávia)

Tanto as falas reticentes quanto as afirmações do tipo “não sei”, presentes em inúmeros momentos da entrevista de Flávia, denotam a impossibilidade de manter um contato mais fraco e íntimo com os próprios sentimentos e desejos, que parecem ter sido soterrados sob uma gama de exigências parentais, incorporadas em um superego rígido e punitivo. A dificuldade mencionada pela participante em relação a não conseguir dialogar com os pais e negociar sua autonomia, o desejo intenso de ser ouvida por eles e ter suas necessidades afetivas e sexuais reconhecidas e legitimadas, parecem ter sido reproduzidos na relação com a entrevistadora, que por vezes sentiu que Flávia tinha muita necessidade de se expressar, mas não encontrava palavras apropriadas, o que denota a falta de um lugar para se colocar o desejo.

[...] Percebi que a insatisfação com a imagem corporal continuava presente, mas que não se tratava apenas do corpo propriamente dito, mas provavelmente tinha a ver com a sexualidade e a constituição de sua identidade. Era como se a participante se questionasse o tempo todo: "Quem sou eu? Que corpo é este, que irrompe em seus clamores? Por que tenho que reprimir minhas necessidades se meu vizinho se permite ter canais de satisfação?”. Senti que ela tinha muita necessidade de falar sobre o que estava vivendo em casa, o ambiente opressivo da vida em família. Os sintomas de TA foram mencionados poucas vezes em seus relatos, indicando que os conflitos internos e a angústia resultante eram prioritários (e, muito provavelmente, anteriores ao quadro psicopatológico). O contato com Flávia despertou em mim sentimentos de compaixão, dó e desejo de abraçá-la com ternura, como se ela clamasse, na transferência, pelo acolhimento de alguém que pudesse compreendê-la. (Diário de campo, entrevista com Flávia) 
Como já mencionado anteriormente, as comparações com a irmã foram bastante reiteradas no relato de Flávia, sempre no sentido desfavorável à participante. Nos primeiros minutos da entrevista, ao descrever o que sentia em relação ao próprio corpo, a participante confidenciou a tristeza que experienciava quando via que a irmã chamava a atenção das pessoas à sua volta, principalmente de homens bonitos. Flávia expressou o desejo de ter “muito seio”, assim como sua irmã, e a mãe mencionou outros aspectos de B. que também eram fontes de insatisfação para Flávia e os quais ela buscava "imitar”, tais como o cabelo loiro, os olhos azuis e a altura. Para a mãe, B. é uma "princesa” que irá se casar com um “príncipe encantado”.

[...] A Flávia acha que a irmã chama muita atenção, mais do que ela, porque a irmã é mais alta, loira, tem os olhos claros, tem peitão, isso nas palavras da Flávia, porque ela chama mais atenção. Mas a Flávia, quando sai, ela chama mais atenção porque ela se veste bem, ela sabe combinar as coisas, ela faz aquela maquiagem bem carregada, então não tem quem não olha. [...] Ah elas são muito diferentes, eu acho que é o que eu falei, eu não acho que... Ela pensa num príncipe encantado, a outra [B.]. Ela vai ser uma pessoa que eu acho, assim, que ela vai se apaixonar e vai casar e pronto. Agora, a Flávia não. A Flávia é mais conquistadora, aventureira, acho que a Flávia vai demorar... (Entrevista com Márcia)

Flávia descreveu várias situações nas quais não se sentia amada e apreciada pela mãe. Apesar de descrevê-la como “sempre presente”, não se sentia amparada em suas tristezas nem valorizada enquanto mulher. Nota-se, portanto, que a presença física da mãe parece não ter sido suficiente para que Flávia internalizasse uma figura materna cuidadosa e afetuosa. Pelo contrário, sentia-se frequentemente sozinha e insegura, buscando delinear, com sofreguidão, seu espaço próprio e sua importância no mundo.

[...] Eu demoro um tempão pra escolher a roupa, aí eu chego pra tomar café, aí eu falo pra minha mãe, e eu culpo, parece tipo que eu culpo ela por não gostar de mim, aí eu saio, vou pra escola. Aí na hora que eu chego na escola, eu tenho vergonha. Eu tenho vergonha de levantar pra ir no banheiro, eu tenho vergonha de fazer pergunta, eu tenho vergonha... [...] E quando eu preciso dela, ela não tá lá, entende? [...] "Se você não melhorar, o problema vai ser seu, você tem que melhorar”, só que, tipo, como se... sabe... Eu me senti... Ela me trata... sabe... Então o problema é só meu? Eu 
sou uma pessoa independente, eu entrei nessa sozinha, então eu saio dessa sozinha? $\mathrm{Na}$ verdade ela é sempre presente, mas ela nunca, sabe... toma atitude. Um dos momentos mais marcantes assim, eu tava lá tentando falar alguma coisa com meu pai, falando com os dois, aí meu pai começava a estressar e tal, aí ele me levava pro quarto e me batia e ela não fazia nada, ela ficava quieta olhando pra mim, não sabia se ela tava concordando ou não. Uma dessas coisas que eu lembro. A outra foi quando mais, tipo... Eu ia sair do ballet, né, aí ela falou: "Eu tinha falado pra você sair faz tempo”, sabe, nem ligava muito. (Entrevista com Flávia)

A mãe parece ter sido internalizada como figura negligente e pouco confiável, na medida em que negligencia o sofrimento da filha e permite que o pai a torture reiteradamente em sessões de abuso físico. Além do sentimento de profundo desamparo, Flávia também descreveu a sensação de ser tratada como uma criança, pois a mãe “não conversava”, apenas negava seus pedidos - por exemplo, o pedido de começar a fazer musculação em uma academia distante de sua casa. Gostaria que a mãe "conversasse direito”, "não tivesse medo de discutir”. Percebe-se que a participante sentia falta de subsídios para entender as coisas e, consequentemente, sentia-se uma eterna criança, incompreendida e, por sua vez, incapaz de compreender o que acontece à sua volta. Sentia-se pequena frente às imposições dos pais, e tinha o desejo, provavelmente compensatório, de ser musculosa: “Eu queria ficar muito maior”. O tamanho, nesse sentido, parecia se referir não apenas ao corpo físico, mas também a uma tentativa de se sentir emocionalmente estruturada e capaz de lidar com as adversidades da vida sem se dobrar. A mãe de Flávia, por sua vez, considera a filha "briguenta, reclamona e contestadora", sempre precisou chamar sua atenção, diferentemente da forma como educava os outros dois filhos, que demandavam menos esforço.

Os recorrentes conflitos e discussões entre Flávia e seus pais, o desejo de que estes oferecessem um espaço para ouvi-la em seus clamores e a sensação de sempre “perder” para a irmã, podem ser consideradas tentativas inconscientes de compreender qual era a relevância que os pais atribuíam a ela e o que sua existência representava dentro da família. José descreveu a seguinte situação ocorrida por ocasião do nascimento das filhas: 
Olha, quando elas nasceram, falo das duas, né, porque nasceram juntas, eu me senti muito feliz. Na época, quando a Márcia ficou grávida, que eram trigêmeos, eu... não pensei em nada, ficou até... Assustou, né. [...] Mas aí, no terceiro mês, o... O feto, né, o terceiro não vingou... A Márcia fazia os ultrassom, via-se só a B. A Flávia não via, então não se tinha, a gente ficou sabendo do sexo bem depois... A Flávia tava meio virada, então o médico falou: “Olha, eu não sei, eu não posso falar." E, lógico, a minha torcida naquela oportunidade era que fosse um menino e uma menina. Inconscientemente, eu nunca falei isso. Não que eu falasse: "Ah, você quer um menino." Não, nunca. E nem fiquei infeliz quando elas nasceram. Fiquei muito feliz. A Flávia nasceu... ruim, ficou vários dias na UTI, né, eu acho até que foi uma falha médica, porque a Márcia estava preparada pra fazer o parto e eles não quiseram, acharam que deviam segurar um pouco mais e aí a Flávia emagreceu muito né, engoliu fezes, teve sérios problemas na... Tanto que na filmagem o médico, o... o fotógrafo lá não filmou a Flávia, porque eles achavam até que naquele momento ela não sobreviveria, porque a $B$. nasceu tranquila, sem problema nenhum, e ela tava muito magra, parecia uma menina da Etiópia, só se via as costelas, assim, só pele e osso. E depois, né, que a gente viu ela, que prepararam ela, lá, e tal, a gente... Deu toda... a... Todo o suporte pra ela. [...] Desde essa época ela já foi meio assim, arredia. As enfermeiras falavam que a Flávia era muito nervosa, mesmo bebê. (Entrevista com José)

Quando o pai conta que “a Flávia não se via, a gente ficou sabendo do sexo bem depois" e que "na filmagem o fotógrafo não filmou a Flávia, porque eles achavam até que naquele momento ela não sobreviveria", evidencia-se a inexistência a que a filha havia sido relegada desde o início. Nem mesmo o pai “botava fé” em que ela fosse vingar. Ela teve, assim, um início de vida extremamente desfavorável, desde a gravidez gemelar - teve de dividir o útero com a irmã, ter de superar a invisibilidade que a recobria e ainda por cima o desejo paterno de que fosse um menino. Depois, ela sofreu fisicamente com o atraso do parto, “emagreceu muito, engoliu fezes, teve sérios problemas”. Seu ingresso no mundo se dá de maneira trôpega, como um ser minúsculo, “muito magra, parecia uma menina da Etiópia, só se via as costelas, assim, só pele e osso". É interessante observar que, por diversas formas, na escolha do sintoma anoréxico se perpetra inconscientemente um enlace fantasmático com esse início. Como se ela se identificasse com essa “menina da Etiópia, [...] só pele e osso”, e respondesse desse lugar às exigências parentais. 
A partir da história narrada pelo pai, evidenciam-se diferenças marcantes na trajetória de Flávia e sua irmã gêmea, desde o ato de nascimento. Enquanto que a participante parecia um bebê inviável, que inclusive foi propositalmente excluído das fotografias e filmagens, e que permaneceu internado na UTI durante meses, a irmã havia sido levada para casa, onde foi cercada de cuidados e pôde ser amamentada ao seio. Quando Flávia dizia: "Eu não sei o que eu sou”, é possível associar com a dúvida que os próprios pais tiveram em relação ao sexo da filha durante toda a gravidez, além do desejo do pai de que o bebê fosse um menino. Portanto, qual seria realmente o desejo dos pais em relação à existência de Flávia enquanto filhamulher? Quais fantasias inconscientes foram alimentadas pela participante a partir da percepção da ausência de fotos de seu nascimento, em contraste com o reinado absoluto de sua irmã nas fotografias? Pode-se pensar que as comparações com a irmã tenham tido seu início nesse momento, que parece ter despertado fantasias no sentido de que a irmã "chamava atenção” suficiente para ser notada, fotografada e filmada, ao contrário de Flávia, condenada ao ostracismo ou a uma existência fragilizada e descarnada, envergando um corpo "só pele e osso”.

\section{O despertar da feminilidade}

A necessidade de se expressar mantinha íntima conexão com o desejo de independência mencionado por Flávia em vários momentos da entrevista. Ao falar de independência, acredita-se que a participante se referia inconscientemente ao desejo de individuar-se, sair da invisibilidade mortificante do ponto de vista da identidade, de modo a poder ter opiniões, vontades e existência própria. É o desejo de experimentar a vida caminhando sobre “as próprias pernas”. Nesse sentido, a percepção de sua própria sexualidade emerge como um contato muito íntimo - e também perturbador - consigo 
mesma, como uma aproximação em relação a seus próprios desejos e, portanto, a necessidade de realização de sua própria existência.

Ainda no que concerne ao desenvolvimento da sexualidade, o interesse de Flávia em manter a amizade da amiga, caracterizada pelos pais como "safadinha", emerge como esforço de aproximação a uma realidade tão desejada como temida, por ainda ser desconhecida. Por meio dessa amiga a participante podia conhecer pessoas diferentes, “mais velhas", com experiências diferentes das suas.

Ah... Porque era muito mais legal! Ela conhecia um monte de menino, a gente saía, ia pra um lugar lá que tinha um monte de gente que ela conhecia, um monte de menino muito mais velho que a gente. E aí era muito mais legal. (Entrevista com Flávia)

Ao conhecer pessoas tão diferentes de si, Flávia parecia estar buscando conhecer a si mesma a partir de seus pares, permitindo-se sondar seus próprios interesses e desejos. A própria sexualidade estava sendo explorada, o que pode ser percebido quando a participante expressava angústias relacionadas a ser chamada de “menino” e “lésbica” pelos amigos, e de “Zé Ruela” pelo pai. Esse apelido dado pelo pai ressoava, de algum modo, aquele desejo primário de que a filha nascesse homem. Quando questionada a respeito de como achava que os pais se sentiam tendo uma filha, Flávia relatou que o pai a tratava de forma "estranha, como se fosse um menino”. Contou que o pai costumava chamá-la para ajudá-lo na reforma do sobrado da casa, e que considerava esse tipo de atividade como tipicamente masculina. No entanto, ao ser solicitada a descrever melhor essa situação, Flávia relatou que o pai costumava convidar apenas o filho, irmão de Flávia, para ajudar na reforma: “Aí eu fiquei: "Mas por quê ele tá chamando o M.?”. Aí eu comecei a ir lá. Porque ele não me chamava antes”. A partir desse relato, pode-se pensar na contrapartida da participante, que não é apenas solicitada pelo pai a realizar as atividades “de homem”, mas que também procura o pai para acompanhá-lo na realização de tais atividades, que ela própria considera como tipicamente masculinas. 
Há, portanto, intenso desejo de estar próxima ao pai, de perceber seu olhar voltado para si. Porém, a realização desse desejo vinha acompanhada de comprometimentos no plano da autoimagem e na vivência da feminilidade, o que pôde ser percebido pelas hesitações e ambivalência com que Flávia assumia seu posicionamento enquanto mulher: em determinados momentos, vestia-se de forma provocante, utilizava batons de cores fortes, pintava os cabelos de loiro e assumia uma postura ostensivamente sedutora, encarnando a imagem-clichê de mulher fatal. Em outros momentos, desejava ganhar músculos, acompanhava o pai e o irmão em atividades "de homem", era chamada de "lésbica" pelos colegas da escola. Essas contradições emergem de forma explícita na questão que ela endereça a si mesma: “Eu sou a fera... Não sei o que eu sou”. Entende-se que a participante está buscando compreender o desejo de seus pais em relação a ela e, consequentemente, conhecer a si mesma para poder ocupar seu lugar no mundo como mulher.

Observa-se que o relato de Flávia traz, de forma subjetiva, o medo do abandono paterno: a participante deseja manter-se próxima ao pai, realizar atividades com ele e buscar formas (o que inclui os sintomas) para que ele a enxergue. Nesse sentido, o TA pode estar relacionado com a percepção do pai como alguém emocional e fisicamente indisponível: ao buscar a aprovação paterna, a filha identifica-se com o pai (Elliot, 2010; Nodin \& Leal, 2005), passando a estar sempre próxima a ele, idealizando-o intensamente. Tal idealização pode ser considerada formação reativa de uma relação pai-filha pouco elaborada (Elliot, 2010).

Flávia teve sua primeira menstruação aos 10 anos de idade, experienciada com bastante desconhecimento a respeito de seu próprio corpo e sentimento de vergonha. Quando a mãe a parabenizou, Flávia pediu várias vezes que ela falasse baixo, para que ninguém a escutasse. A participante apresentou dificuldades para explicar a vergonha que sentira naquela época: 
Ah não sei por quê, parecia uma coisa assim, que só a mulher tinha. Ai, que era estranho, que se meu pai e meu irmão soubessem, eles iam ficar: "Nossa, quê que é isso? Olha, ela já menstruou”, sabe? E eles iam ficar pensando... E eu pensava: "Nossa, mas eles vão saber que eu menstruei, vão ficar percebendo que eu mudei" [riso] [...] Eu achava que era uma coisa de mulher, assim, que não podia falar, eu achava que era uma coisa sigilosa, não sei por quê. (Entrevista com Flávia)

Nota-se que a menarca, como símbolo do devir da feminilidade, indicava que Flávia estava deixando de ser criança e caminhando no sentido de se tornar mulher ("mocinha"). A vergonha e o desejo de esconder a menstruação podem ser considerados, portanto, consequências das dificuldades que Flávia vinha vivenciando em relação à sua existência enquanto filha-mulher. Como poderia se tornar mulher se ainda se considerava "a fera"? Seria ela uma mulher feroz?

A mãe não demonstrou dificuldades explícitas ao tomar conhecimento da menarca da filha, tendo apenas dito: “[...] mas era mais uma preocupação, né, não resta dúvidas, porque é mais uma mulher, né...”. Ao ser indagada a respeito do que significava o fato de Flávia ser “mais uma mulher”, Márcia respondeu: “Não, não, eu não me preocupei naquela época, né, porque eu não pensei que as coisas fossem tomar esse rumo, que a Flávia tinha propensão a esse distúrbio, né. A gente não imaginou isso e também não achei que ela fosse extravasar a sexualidade dela dessa forma”. Não foi possível esclarecer a que “distúrbio” Márcia estava se referindo, se ao TA ou às questões relacionadas à expressão da sexualidade, sobre as quais havia contado em momentos anteriores da entrevista, expressando o medo de que Flávia pudesse "ser esquizofrênica”. No entanto, evidencia-se que a mãe estabelecia relações entre a sexualidade da filha e o transtorno do comportamento alimentar, ainda que de forma inconsciente e dificilmente acessível em uma única entrevista.

Para José, a menarca de Flávia foi algo “natural”, mas que poderia ter acontecido em idade mais avançada, pois, segundo o médico da família, a menstruação "tinha influência no crescimento". Ou seja, quando questionado a respeito da forma como se sentiu ao saber que a 
filha havia tido sua primeira menstruação, José nitidamente recorreu à concretude, evitando dar qualquer vazão aos sentimentos - possivelmente angustiantes, relacionados ao desenvolvimento da sexualidade da filha - e priorizando o discurso biomédico. Não foi possível aprofundar o assunto, uma vez que o celular de José começou a tocar incessantemente. Após cancelar as chamadas duas vezes, na terceira vez optou por desligar o celular: “Deixa eu desligar essa porcaria... É a Márcia”.

[...] Considerando-se que a esposa encontrava-se na sala de espera da instituição hospitalar, bem próxima à sala onde estava sendo realizada a entrevista com seu marido, pode-se pensar nas insistentes ligações como indícios de persecutoriedade e tentativa de controle por parte da esposa, relacionada às fantasias em relação aos conteúdos que o marido pudesse estar compartilhando com a pesquisadora. A pesquisadora poderia estar sendo tomada como uma pessoa estranha, que estava adentrando as fronteiras da intimidade familiar, que Márcia se esforçava por manter intactas. (Diário de campo, entrevista com José)

A partir do evento narrado, hipotetiza-se que a entrada de pessoas novas na família, ainda que de forma passageira e pontual, tal como uma pesquisadora realizando entrevistas, consistia em uma situação que representava ameaça à dinâmica familiar instituída e preservada, sobretudo pela mãe. A forma como a mãe lidou com a “entrada” da pesquisadora na vida íntima familiar demonstra, no plano da relação transferencial, o modo como ela provavelmente lidava com a introdução de outras pessoas no círculo familiar, tais como amigas e possíveis namorados da filha. Hipotetiza-se que a mãe se sentia invadida e persecutoriamente ameaçada com a possibilidade de a nova pessoa ameaçar romper a estabilidade e abalar a organização familiar que ela tanto prezava.

\section{Relacionamentos afetivos e vida sexual}

Na época da entrevista, Flávia nunca havia tido relações sexuais, apesar de ter relatado que "gostaria de já ter feito" sexo. Sentia-se "pressionada” sempre que se encontrava em situações de intimidade com alguém e, para ilustrar tal sensação, Flávia contou de vezes em 
que estava "ficando" com algum garoto em festas e seu pai a viu. Nesses momentos, a participante sentiu-se "travada", como se o olhar do pai a impedisse de se aproximar da própria sexualidade.

Ah eu não sei, eu acho que vai dar alguma coisa errada, eu fico lá: "Vai dar errado", me sinto insegura, sei lá. Eu acho que, primeiro, eu não penso nisso... Tem hora que eu sinto... Eu tenho vergonha, sabe, eu não sei... Eu tenho vergonha. (Entrevista com Flávia)

O pai me colocava de forma bastante invasiva, tanto no relato de Flávia quanto na relação com a pesquisadora. Interrompia os questionamentos, falava mais alto e, em situações de grupo terapêutico, impedia que outras pessoas se pronunciassem. Havia uma agressividade latente que podia ser facilmente percebida.

No dia em que a entrevista estava marcada, José compareceu ao grupo de apoio psicológico dedicado aos familiares, coordenado por mim e por outra psicóloga do serviço. O encontro do grupo ocorreu antes da entrevista. José chegou suado e com os primeiros botões da camisa abertos, deixando aparecer boa parte do peito, sendo o primeiro a falar. Disse que não gostava de "ser obrigado" a ir ao grupo, pois precisava trabalhar. [...] Mostrou estar bastante irritado e contrariado. Com uma atitude um tanto quanto agressiva, mal deixava as psicólogas e os outros membros do grupo se pronunciarem. A sensação despertada foi de invasão e raiva. (Diário de campo, entrevista com José)

A partir dessas percepções a respeito do pai, pode-se pensar na internalização que

Flávia tinha operado da figura paterna, que possivelmente era representada como figura castradora e invasiva, que impedia a filha de realizar seus próprios desejos. Permanecia “travada”, presa ao desejo do pai.

"Então, você [Flávia] quer sair com ele? Então tá bom, manda ele vir aqui, conversa com seu pai, o pai dele é amigo do seu pai, ele conhece a gente, quando era mais novo vinha aqui em casa, então ele vem aqui, conversa comigo, conversa com seu pai, fala onde vai. A gente não quer que você saia com ninguém que você não, não namore. Você tem que ter consciência e nós também temos que saber onde você vai.” (José, citando discurso da esposa) 
Quando questionado a respeito de seus sentimentos em relação ao desenvolvimento afetivo e sexual da filha, José apresentou um relato emocionalmente distanciado, sempre evitando ter acesso aos sentimentos, dando prioridade as aspectos de concretude. Relacionou a sexualidade com a necessidade de amadurecimento, e este último, por sua vez, ao trabalho e ao crescimento financeiro. José acreditava que, quando o indivíduo amadurecia, ele podia ter consciência da importância de trabalhar e das consequências de não trabalhar, e a sexualidade seguia o mesmo caminho: o indivíduo amadurecido podia ter consciência de que "aquilo não era só uma brincadeira”. O participante fez uma equivalência entre a sexualidade e o ato de comprar um carro: “[...] eu tinha que trabalhar, eu precisava trabalhar, eu tinha consciência daquilo, sexualmente a mesma coisa. Depois quando eu adquiri meu carro não era só uma brincadeira, eu tinha consciência”. Nota-se uma intensa dificuldade para relatar sentimentos, o que também era expresso pelo constrangimento ao falar de sexo com a filha.

No relato de José evidenciou-se que o constrangimento para falar de sexo com Flávia estava relacionado à forma como os homens costumam lidar com as mulheres:

Ah, tem, né [expressando incômodo]... A gente sempre fala. Que nem você estar na roda de amigos e um cara falar da sua filha, ali, não bate bem, né. E a gente sabe até que seria natural, né, às vezes eu falava, você vê na televisão, né, a filha posando nua. "Ah, é bonito, e tal." Mas lá dentro você: puta que... Não é bem por aí, eu acho que não daria muito certo. Mas você aceita, né. [...] Eu acho que a gente não foi preparado, né, pra isso. Eu acho que, apesar de todo estudo, de toda abertura que eu tive na faculdade, eu venho de uma época que era reprimido isso. Então são conceitos que a gente vem trazendo lá de trás ainda, né, que eles... não desaparecem do dia pra noite, eles vão... Com o tempo você vai modificando, tem a sua cabeça, lógico, mais aberta, mas tem coisa que eu acho que não sai, né, é questão até da personalidade da gente [riso]. Não sai. (Entrevista com José)

Pode-se pensar no modo como o próprio pai lida com a sexualidade, e a sexualidade feminina em particular, encarando-a de forma pejorativa e aproximando-a a um sentido de promiscuidade. Nessa linha de raciocínio, pode-se compreender o desejo que José nutria de ter um filho: possivelmente existia a fantasia de que um garoto jamais seria olhado pelos 
outros como “promíscuo”, jamais seria desejado por outros homens e jamais seria encarado da mesma forma que José encarava as mulheres. De que forma Flávia poderia emergir em sua condição de mulher, se o pai não podia valorizá-la enquanto tal?

Ao descrever seu próprio desenvolvimento psicossexual, José contou que iniciou a atividade sexual muito precocemente, aos 13 anos. Revelou, rindo, que não se lembrava da primeira vez em que teve relação sexual. O relato de José mantém um distanciamento emocional de suas próprias experiências, que novamente associa com dados concretos, tais como trabalho, independência financeira e compra de veículo próprio. O participante parecia fazer equivaler sua "potência” sexual à "potência” de ter conseguido amealhar dinheiro suficiente para comprar seu próprio carro aos 13 anos de idade.

Pra ser honesto, eu acho que eu não lembro da primeira vez, viu, não sei [riso] [...] Eu diria que no passado era muito mais reprimido, a questão sexual. [...] Antigamente se você falava em sexo, você... O que a gente fazia era... Nesses "inferninhos" mesmo, né, esses lugares aí que era apropriado, então. [...] Das primeiras vezes foi assim, foi nesses lugares mesmo, acontece que eu tive facilidade, pelo momento meu, né, de trabalho, porque eu comecei a trabalhar com 12 anos em banco, e naquela época, banco pagava um salário muito bom. Então, hoje, vou falar, bancário ganha uma merreca hoje, mas na minha época não, eu ganhava muito dinheiro, porque eu comecei com 12 anos, se comparado com hoje eu ganhava... Depois de três, quatro meses eu ganhava oito, 10 salários mínimos. E eu saí do banco ganhando muito bem. Então, tanto que eu te falei, com 13 anos eu já comprei o meu carro. [...] Mas, qual a facilidade? Pela condição financeira daquele momento e os amigos que eu tinha eram todos pessoas idosas, mais velhas do que eu, eu era criança. Mas eu era bem, teoricamente, maduro, né, pela idade que eu tinha, então eu ia junto. Então era: "Vamos pra [cidade vizinha]?”, pegava o carro e ia. Então passava a noite lá. Então, como diz o outro, era casa de prostituição. [...] (Entrevista com José)

Apesar de mencionar tantas vezes a idade com que começou a trabalhar, é possível perceber que a independência financeira precoce de José acarretou problemas no sentido de conduzi-lo a atividades típicas de pessoas mais velhas, às quais o participante, aos 13 anos de idade, não tinha condição emocional suficiente para metabolizar. Além disso, evidenciaram-se durante a entrevista frequentes esquivas e tentativas de evasão do assunto em pauta e demora em confidenciar sobre as idas furtivas à “casa de prostituição” na adolescência, que podem 
estar relacionadas à dificuldade de falar abertamente sobre suas atividades sexuais com prostitutas frente à figura da pesquisadora-mulher. Tal interpretação parece também ter apoio na seguinte fala do participante: “Olha, é, até, até, eu diria pra um homem... Falar isso acaba sendo... Seria constrangedor se eu tivesse falando com um homem, mas eu sou monogâmico. Desde que eu casei eu sou fiel à minha esposa. Eu nunca saí com outra pessoa”. No entanto, em momento posterior da entrevista, José confidenciou que manteve dois relacionamentos concomitantes durante três anos, um com sua esposa e outro com uma mulher de sua cidade natal. Portanto, conclui-se que há uma tentativa, por parte de José, de ocultar atos que poderiam ser socialmente dignos de reprovação.

No que concerne à relação do casal parental, na época da entrevista estavam casados havia 28 anos, sendo que eles haviam namorado por cinco antes do casamento. José confidenciou que, antes de se casar, "sempre havia sido muito mulherengo". Sua mãe o aconselhava a se casar apenas depois que "já tiver feito o que tinha para fazer em sua adolescência: viajar, namorar, curtir a vida", porque quando se casasse, deveria ser fiel à esposa. José acreditava que havia "seguido inconscientemente" o conselho da mãe, pois "era avesso, meio arredio", e "gostava de namorar". E, mais uma vez, a compra do veículo emergiu no relato:

[...] Tá, eu gosto de namorar, de ir em baile, na, né, que hoje é balada, antigamente era baile, né... [a mãe dizia] "Faça." E eu, inconscientemente, eu segui, né, porque eu era meio avesso ali, eu era meio arredio. Eu, com 13 anos, eu comprei o meu primeiro carro, meu pai nunca teve. Então eu falo isso pros meus filhos, eles: "Ah pai, que é isso?” Meu pai, ele dirigia caminhão grande, de transporte, e eu aprendi a dirigir no caminhão. Eu fui tirar carta com uns 18 anos, sem fazer nada, eu já sabia dirigir. Então eu fui precoce. (Entrevista com José)

Quando questionado sobre o termo “mulherengo", que empregou ao se referir a si próprio no passado, José relatou que os relacionamentos que mantinha antes do casamento eram “muito sem vínculo de responsabilidade”. Nota-se que o senso de responsabilidade 
mencionado pelo participante acompanhava o ideal cultural de casamento, segundo o qual os membros do casal devem ser fiéis um ao outro e à família. Porém, tal responsabilidade não se aplicava à Márcia enquanto pessoa, uma vez que a "monogamia" - que, segundo o relato de José, parecia remeter à ideia de respeito para com o cônjuge - passou a acontecer apenas após o casamento propriamente dito, e não durante os cinco anos em que namoraram e, portanto, já tinham um vínculo afetivo estabelecido. Como já mencionado anteriormente, durante o namoro com Márcia, José manteve outro namoro concomitante, com uma mulher de sua cidade de origem:

Ah, tava junto com uma menina hoje, ou... Como diz o outro, uns meses, ou um ano... Namorei uns dois, três anos uma moça lá de [nome de cidade] também... Até namorei a moça... Namorava a Márcia aqui e namorava ela lá. [riso] E ela era ainda a primeira namorada, e acabei largando lá e depois casei com a Márcia. (Entrevista com José)

Apesar de sua mãe ter contado dessa outra namorada para Márcia, esta não mencionou o fato em sua entrevista. Todos os questionamentos da pesquisadora em relação ao relacionamento conjugal foram respondidos de forma monossilábica, e logo eram inseridos ou retomados assuntos relacionados à Flávia. As fugas recorrentes em relação aos temas que faziam com que Márcia se aproximasse de sua própria vida afetiva e sexual, podem ser consideradas indicativas de que tais vivências eram bastante angustiantes. Nesse sentido, a forma como tentava arduamente controlar a vida da filha pode ser compreendida como modo inconsciente de expressar o desejo de que esta seguisse "as suas regras, o que ela havia aprendido, o que ela achava certo”, regras que, para Márcia, ainda representavam a forma correta de viver a vida. Normas que, se seguidas, poderiam levar à felicidade. Hipotetiza-se que a negação e recusa de olhar para possíveis insatisfações conjugais tinha a função de evitar questionar certas regras e pautas de conduta que vinham regendo sua vida desde o início, e que haviam sido transmitidas e mantidas na família pela via transgeracional. 


\subsubsection{Família Garcia}

Helena, a filha: "Eu sou diferente das outras pessoas... Feia, estranha, esquisita" Golita, a mãe: "Eu acho que a Helena precisa ser amada”

Pedro, o pai: “Ah, nunca me interessei, sinceramente. Isso é função do pai?”

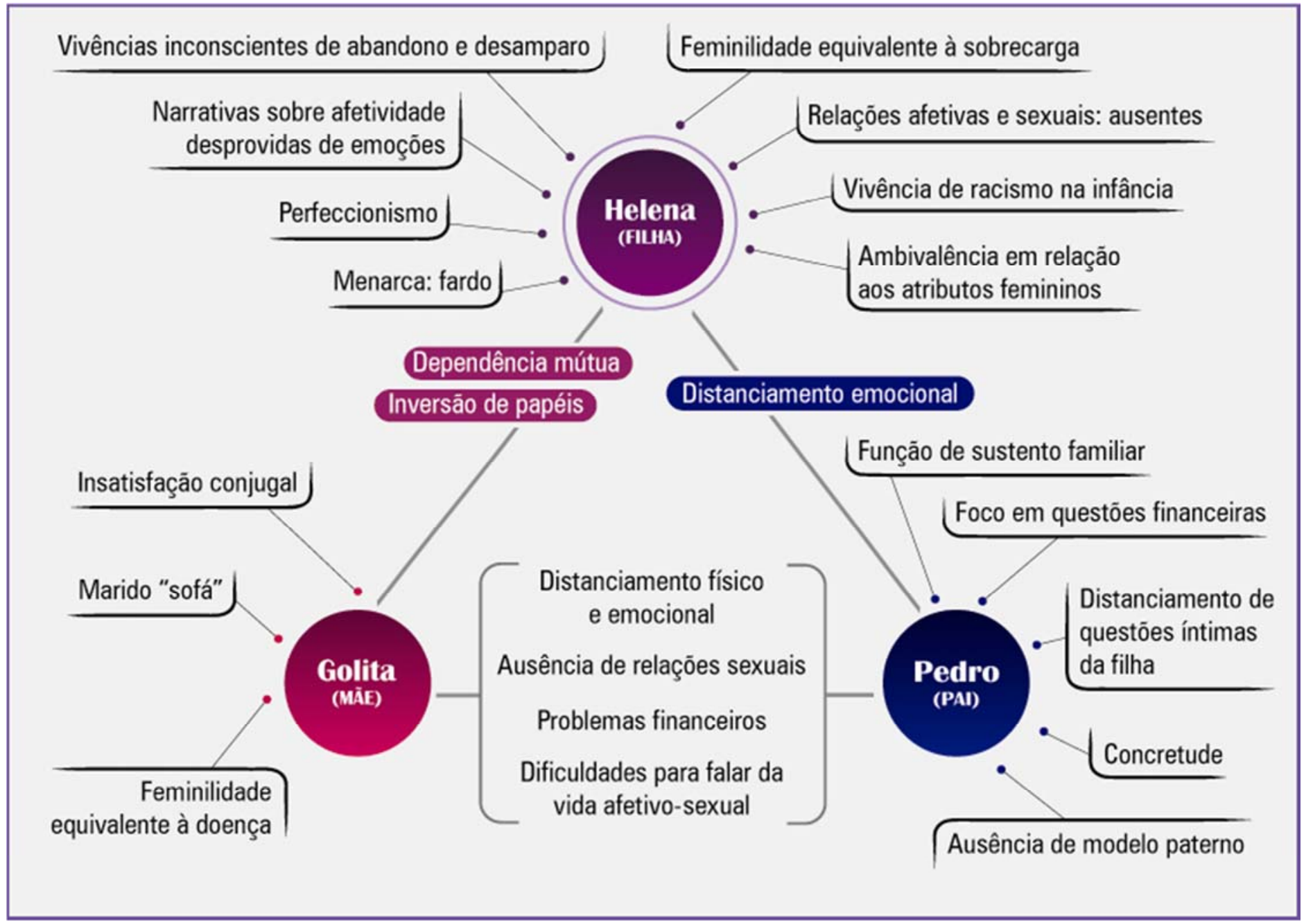

Figura 4. Mapa de associação de ideias da família Garcia. 
Helena havia iniciado o tratamento no GRATA cerca de sete meses antes da realização da entrevista. Seus dados antropométricos eram: $33,3 \mathrm{~kg}, 1,56 \mathrm{~m}$ e $\mathrm{IMC}=13,8 \mathrm{~kg} / \mathrm{m}^{2}$, que caracterizava desnutrição grave. Foi encaminhada ao serviço por um médico de sua cidade, com queixas de insatisfação corporal (principalmente em relação às pernas, que achava grossas demais). A participante referiu AN desde os 15 anos, quando iniciou restrição alimentar devido ao desejo de emagrecer, apesar de sempre ter apresentado baixo peso, segundo o relato da mãe. Helena também referia aversões a alguns alimentos, tais como: arroz, feijão, massas, leite. Segundo dados do prontuário, a participante também apresentava traços obsessivo-compulsivos e de transtorno de personalidade borderline, ainda a serem confirmados pela equipe psiquiátrica.

$\mathrm{Na}$ época da realização da entrevista, os dados antropométricos de Helena não apresentavam mudanças significativas: o IMC havia aumentado apenas $0,2 \mathrm{~kg} / \mathrm{m}^{2}$. A participante vestia-se com calças jeans escuras, sapatilhas pretas, blusa e jaqueta também de cores escuras. A quantidade de maquiagem no rosto chamava a atenção:

No dia da entrevista, deparei-me com os mesmo olhos grandes e fixos, em um rosto fortemente maquiado. Aquela maquiagem carregada, cuja cor esbranquiçada destoava do resto do corpo negro, me fez pensar em um perfeccionismo acentuado, onde nenhuma "imperfeição" poderia ficar à mostra. Posteriormente, quando Helena mencionou na entrevista os ataques recebidos da avó materna em relação à cor de sua pele, pude começar a compreender toda aquela maquiagem-máscara. (Diário de Campo, entrevista com Helena)

Helena, assim como seu pai, tinha a pele negra. A mãe, em contrapartida, tinha a pele muito branca e os cabelos claros. O rosto de Helena destoava do resto do corpo, pois o excesso de maquiagem tornava-o esbranquiçado. Os olhos grandes eram marcantes tanto pela maquiagem quanto pela forma fixa com a qual ela olhava para a pesquisadora. O silêncio e as reticências configuraram a maior parte da entrevista.

O discurso de Helena era repleto de momentos de silêncio e reticências, desprovido de emoções, expressões de afeto e simbolização. Percebi uma fixação acentuada no 
concreto, que envolvia principalmente a perda de peso e a insatisfação com a imagem corporal. (Diário de campo, entrevista com Helena)

A composição familiar incluía a mãe, que tinha 44 anos de idade e trabalhava como artesã, pois apresentava um problema na coluna e não podia realizar esforço físico; o pai, de 45 anos e que trabalhava na "área de ferramentaria"; e dois irmãos mais novos, sendo um de 21 anos e outro de 15. Tanto o pai quanto a mãe possuíam ensino fundamental completo. Helena e o irmão mais velho haviam completado o ensino médio completo e cursos técnicos a participante realizou curso técnico em Moda e trabalhava como vendedora de roupas. Na residência moravam os cinco membros da família. A renda aproximada relatada pelo pai era de 2.200,00 reais. No entanto, a pontuação no CCEB/2015 indicava participação no estrato socioeconômico B2, que engloba rendas de aproximadamente quatro mil reais. Trata-se, portanto, de uma família economicamente desfavorecida, considerando-se que a renda mencionada sustenta cinco membros.

\section{O transtorno alimentar}

De forma um tanto monossilábica e com discurso empobrecido, Helena relatou vivenciar insatisfação com o corpo desde os 15 anos de idade, juntamente com intenso sentimento de culpa que lhe assaltava logo após ingerir algum alimento, inclusive água. A precipitação dos sintomas foi relacionada pela participante ao adoecimento da mãe, que precisou se submeter a uma cirurgia na coluna, atribuindo a Helena a responsabilidade de cuidar da casa. Nessa época, a participante referiu sentir-se muito sobrecarregada, pois além de estudar, precisava “lavar, passar, cozinhar, limpar”.

Elliot (2010) refere que muitas jovens com AN experienciaram a aquisição - ou atribuição por parte dos pais - de responsabilidades parentais muito precocemente. A necessidade de exercer tais responsabilidades despertava intensos sentimentos de ansiedade, 
além de confundir o psiquismo das jovens, uma vez que se tratava de responsabilidades muito sérias para sua idade, disponibilidade e condição de amadurecimento. Além disso, o mencionado autor também pontua que a ausência emocional do pai faz com que a filha necessite amadurecer muito cedo. Acredita-se que essa interpretação possa ser estendida para o casal parental enquanto unidade, ou seja, o adequado amadurecimento emocional e a organização da realidade psíquica da jovem dependem, dentre outros fatores, das figuras parentais, que precisam proteger a filha das situações que a ameaçam (McDougall, 1991).

Além da sobrecarga, Helena também se mostrou como alguém que sofre por seu perfeccionismo acentuado: manter o peso desejado (aproximadamente $30 \mathrm{~kg}$ ) emergiu no relato como um meio de alcançar seus objetivos e, consequentemente, a dificuldade de manter tal peso era fonte de grave frustração consigo mesma. O perfeccionismo também parecia permear outros aspectos de sua vida:

[Não gosta de errar] Em nada! Eu nunca gostei de errar na escola, nunca gostei de tirar nota baixa. Na verdade, eu nunca tirei nota baixa, porque eu sempre corri muito atrás. Eu não gosto de errar em nada, se eu erro pode ser em alguma coisa mínima assim, mas eu não gosto. (Entrevista com Helena)

Quando errava, Helena dizia que “pensava naquilo pra sempre”. Também relatou sentir-se "feia, estranha, esquisita", e diferente das outras pessoas. Tais sentimentos pareciam estar relacionados com comentários depreciativos recebidos da avó, que dizia que Helena era suja devido à cor de sua pele.

[...] Porque sempre para a família da minha mãe, pra você ser bonito, você tem que ser loiro, de olho azul. Do jeito que é o padrão deles. Como eu nunca fui, então eu sempre convivi com aquilo. [...] que eu fosse feia, esquisita, porque eu não era do jeito que eles queriam que eu fosse. (Entrevista com Helena)

Segundo Golita, a filha apresentava "nojo" da comida, como se fosse "algo que não era limpo”. A mãe atribuía o início do TA às “coisas da adolescência”, que incluíam uma 
desilusão amorosa, na qual o garoto por quem Helena era apaixonada havia começado a namorar outra garota. Apesar de a desilusão ter acontecido havia nove anos, Golita relatou que a filha não pode ouvir falar o nome do garoto e, desde então, começou a "se pôr defeito": "Foi desse dia então que ela começou a só chorar, falar que tava feia, que tava gorda, que tava não sei o quê que tem... Porque antes disso não, ela não se punha defeito, ela encarava a vida numa boa.”

Desde a assim nomeada “desilusão amorosa”, Golita percebia que a filha havia se fechado para amizades e outros relacionamentos interpessoais e afetivos. O sentimento de solidão havia passado a ser imperativo na vida de Helena que, apesar de reclamar do fato de não ter amigos, segundo o relato da mãe, parecia preferir ficar sozinha. No entanto, o relato de Golita trouxe um dado marcante: a percepção de que o TA poderia ser uma expressão de necessidade de cuidado.

[...] Mas uma coisa que me preocupa, eu tenho uma coisa na minha cabeça que me incomoda, eu acho assim, ó: parece que hoje ela fica um pouco presa nessa doença, porque ela quer dizer assim: "Mãe, eu cuidei tanto de você, agora acho que tá na hora de você cuidar de mim”. [...] Então, parece que tem hora que ela não quer melhorar, você entende o que eu quero dizer? Parece que ela quer dizer: "Mãe, agora é hora de você cuidar de mim, todo aquele tempo que eu cuidei de você". Porque eu fiquei de 98 até 2004 operando da coluna, você faz ideia? Foram três cirurgias em seguida, assim, engatilhadas. Quase uma atrás da outra. (Entrevista com Golita)

O pai, Pedro, mostrou uma visão mais objetiva e concreta do TA, creditando que a insatisfação de Helena com o corpo poderia estar relacionada ao curso de moda e, consequentemente, ao padrão físico das modelos. Quando questionado a respeito de possíveis acontecimentos que poderiam estar relacionados ao início do TA, Pedro forneceu respostas bastante superficiais, sempre se referindo a eventos relatados a ele pela esposa, o que sugere distanciamento afetivo entre pai e filha. Algumas observações do diário de campo ilustram tal distanciamento:

Tive muita dificuldade na condução da entrevista, pois as falas de Pedro eram muito confusas e por vezes não pude compreender o que ele estava tentando me dizer. Não 
se tratava de dificuldade na fala, mas no próprio raciocínio: era como se o participante nunca houvesse pensado nos temas que eu estava abordando, e sentia-se "perdido" com o que estava sendo questionado. Não pude compreender o sentido de muitos de seus relatos. (Diário de campo, entrevista com Pedro)

Percebe-se que o pai não compreendia a gravidade do quadro psicopatológico da filha. De fato, não percebia o transtorno como uma ameaça à vida da filha, uma vez que acreditava que se tratava de uma fase, comparando o problema a "gostar de bicicleta".

Ah, eu achava que era fase de... Do dia a dia da pessoa, né, uma fase que tá enfrentando, né. Igual o meu filho normal, né, o outro filho que eu tenho... Tem 20 anos... Teve uma fase, né, depois ele mudou, primeiro gostava muito de bicicleta, isso e aquilo outro, isso e aquilo outro, e achava que ia passando, assim, como se fosse uma fase, né, agora ele quer outro tipo de, de coisa. Eu achava que era uma fase que a pessoa ia passando e que ia... terminar. E eu tava enganado, né. (Entrevista com Pedro)

Considerando-se o trecho exposto e o fato de que Pedro havia comparecido ao tratamento da filha apenas uma vez em sete meses, hipotetiza-se que se trata de um pai emocionalmente distante, voltado para o mundo do trabalho e com dificuldades de se aproximar da família e manejar os próprios afetos. A disposição paterna para cuidar da filha tem sido relacionada na literatura com a forma como esta última lida com a realidade e as situações adversas (Elliot, 2010). É possível, portanto, estabelecer relação entre a dificuldade de Helena para encarar conflitos - tanto os práticos, como os de natureza psíquica, e a impossibilidade de encontrar no pai um espaço mental disponível para aliviar sua dor. A seguir, as relações familiares serão mais bem descritas.

\section{As relações familiares}

Pedro relatou que é muito parecido com a filha: ambos são “fechados", com dificuldade de expor o que pensam e sentem. Para ele, apoiar e acolher a filha em suas angústias parecia estar relacionado com o fato de não ter recebido apoio e acolhimento em sua 
própria posição de filho: o participante relatou que havia perdido o pai aos dois anos de idade e, portanto, “não teve oportunidade de chamar de pai” e não teve alguém em quem "se espelhar”. Pode-se pensar na importância que existe em se sentir acolhido enquanto filho, para então poder reproduzir tal acolhimento quando na posição de pai.

A dificuldade de aproximação e consequentemente distanciamento emocional entre pai e filha parece ter resultado em uma única via de contato, a financeira. Segundo Pedro, a mãe encontra-se mais próxima da filha no dia-a-dia, é responsável por cozinhar e oferecer cuidados: "ela escora mais na mãe”, e procura o pai para "pagar alguma coisa, fazer alguma coisa pra ela, tipo coisa que a mãe dela não consegue fazer”. Tais atividades incluíam: ir ao banco, levar ao trabalho e ao curso de moda. As questões financeiras foram mencionadas várias vezes por Pedro, emergindo como mediadoras das relações do pai com os filhos e a esposa. Quando questionado a respeito do relacionamento conjugal, Pedro relatou:

Ah... Até então... Normal, bem, né... Vou dizer que a gente deu aí a vida, né. Sempre tem umas discussões, coisa assim... Aí vem também, né, a... A dificuldade financeira que... Ninguém gosta de passar por isso, mas sempre passa. Você tem um bom emprego aí de um dia do outro você perde o emprego aí... suas condições de vida muda, né, aí tem sempre aqueles, né, contratempos que vai... Sufocando, aí. (Entrevista com Pedro)

Acredita-se que a questão financeira sempre presente no relato do pai indica a concretude psíquica, relacionada com a dificuldade de pensar, viver e falar sobre afetos, sentimentos e emoções. Dessa maneira, a relação conjugal enquanto vínculo sentimental parece ter sido deixada de lado e o casamento parece ter se restringido ao exercício da paternidade e provisão financeira.

Apesar de todas as dificuldades de Pedro para se aproximar emocionalmente da família, o distanciamento parece ser mútuo no que diz respeito à esposa. Esta última refere-se ao marido como “sofá”, remetendo-se à sua presença-ausência na família. 
Quando ele tá arriado, como se diz o ditado, ele não quer conversa com ninguém. Entendeu? O dia que ele tá de boa, ele conversa, o dia que ele não tá, minha filha... Ele não conversa com ninguém, ele fica como se fosse um sofá mesmo. Não presente. É difícil, entendeu, um marido que tá ausente... Quer dizer, um marido que tá presente e ao mesmo tempo tá ausente. Complicado. [...] É um marido que não te dá atenção, não dá atenção pros filhos... Parece que você é um peso, ele já chegou a falar que a família tá sendo um peso pra ele, então isso vai te magoando. O marido falou que tá cansado, que tá com saco cheio de tudo, então você vai... Você vai esgotando da vida [...] (Entrevista com Golita)

Ao comparar o marido com um sofá, hipotetiza-se que Golita sinta-se sozinha e desamparada. Em uma relação na qual os sentimentos não são expostos, a via de expressão encontrada parece ter sido o transtorno de Helena: quando Golita dizia ao marido “a Helena quer sua atenção", evidencia-se uma projeção na filha de conteúdos da própria esposa, que deseja a atenção do marido.

No que diz respeito aos filhos, Golita falou a respeito de uma divisão de “lados” dentro da família, como se houvesse o lado da mãe e o lado do pai, e os filhos precisassem escolher em qual lado permanecer.

Ah, eles ficam tudo chateado. Tudo chateado, porque eles são todos do meu lado. Porque eles sabem que o pai tá errado, porque ele trata todo mundo mal. Sabe aquela pessoa que é ríspida? Ele conversa com todo mundo, com a gente com rispidez. Assim, ele conversa com ela, dá atenção. Então nessa parte não é que eu quero fomentar o pai contra a filha, mas é que eu vejo que ela não tá errada. Entendeu?Então fica difícil, entendeu? Aí a gente vai conversar com ele e ele fala: “Não, você tá jogando meus filhos contra mim”, mas eu não tô jogando. (Entrevista com Golita)

A divisão de lados esteve presente durante toda a entrevista de Golita, na qual se evidencia pouca implicação nos problemas familiares e várias acusações em relação ao marido, como se a participante tentasse mostrar que o lado dela estava “certo”.

A insatisfação com o relacionamento conjugal também me pareceu bastante clara na entrevista - "marido-sofá" -, junto com uma dificuldade de aproximação de seu próprio papel na dinâmica familiar: enquanto Golita dizia que gostaria que o marido fosse mais participativo no tratamento de Helena, me lembrei de um grupo no qual ele participou, e que suas tentativas de falar ou questionar foram cortadas pela esposa, 
que dizia: "Ele não sabe de nada”. Me perguntei se Golita de fato oferece espaço para que o marido esteja presente. (Diário de campo, entrevista com Golita)

Portanto, nota-se que, apesar dos sentimentos de solidão e do desejo de se aproximar do marido, Golita parece ter optado inconscientemente pelas acusações e pelo julgamento, talvez como consequência da impossibilidade de expressar o afeto e também como expectativa de que o marido "enxergasse" o que ela considerava como "erros" e passasse a ser mais presente na família.

Helena denominou sua relação com a mãe como “normal”, sem discussões, mas sem proximidade. Contou que, quando tinha aproximadamente 10 anos, a mãe precisou se submeter a vários procedimentos cirúrgicos devido a um problema na coluna vertebral, tendo atribuído as funções da casa à filha. Assim, Helena teve que assumir responsabilidades e obrigações muito precocemente, e se sentia sobrecarregada. Considerava que não havia tido chance de viver a vida conforme a sua idade, viver o amadurecimento no tempo devido.

[Se sentia] Mais nova porque eu nunca vivi nada, de acordo com a minha idade... E às vezes muito mais velha, porque eu acho que eu vivi muita coisa que eu não deveria ter vivido, numa idade que eu era nova. Assim, essa responsabilidade de cuidar de casa, de cuidar de irmão, sabe, de buscar irmão na escola... Sabe, às vezes de ter que sustentar a casa, quando eu comecei a trabalhar, porque não é uma responsabilidade que era minha, então eu tomei aquilo pra mim. Então, eu me sinto mais velha assim, mas, às vezes, mais nova por, sei lá, não ter tido as experiências de acordo com a minha idade. (Entrevista com Helena)

Quando falava de suas próprias experiências, falava no tempo verbal passado: “Não ter curtido a juventude”, como se a juventude já tivesse passado e ela não tivesse apenas 24 anos de idade. O relato da participante remetia a ideias de morte, como se sua vida estivesse próxima do fim.

No entanto, apesar do vazio no discurso manifesto, o contato com Helena despertava intensos sentimentos contratranferenciais de vazio e solidão, que me deixavam muitas vezes sem saber o que dizer, mergulhada em um universo de nada. Por vezes me percebi perplexa com a ausência de vida, como se Helena vivesse no "piloto 
automático”. Fez-me pensar não em vida, mas em sobrevida. (Diário de campo, entrevista com Helena)

Ainda em relação à saúde da mãe e à assunção, por parte de Helena, das responsabilidades domésticas, Golita disse: “Ela sempre foi um pouco minha mãe”. Apesar de ter solicitado a ajuda do marido quando precisou se submeter à primeira cirurgia, Golita relatou que o marido “deixou a desejar e, em vez dele cuidar da casa, ele deixava por conta dela”. Como já mencionado anteriormente, tendo em vista que as responsabilidades atribuídas à Helena em idade muito precoce podem tê-la sobrecarregado, a mãe considerava que o TA poderia ser uma forma de pedir ajuda e cuidados. Foi a vez de Helena ter a "saúde debilitada".

Golita acreditava que Helena culpava o pai pela sobrecarga de tarefas, dizendo que ele não a ajudava e “jogava tudo" para que ela fizesse. Em contrapartida, o relato de Helena na entrevista remetia à uma mágoa da mãe: “Assim, ela não aguenta fazer muita coisa, mas o que ela aguenta fazer, ela também não faz, sabe... Ela não é uma mãe, assim, muito dedicada a casa, aos filhos, fazer comida, essas coisas, ela não faz muito. Não sei porque... Mas, assim, coisas que ela aguentaria fazer, ela não faz. Às vezes, ela espera eu chegar do serviço pra fazer”. Portanto, é possível perceber que Golita apresentava dificuldades para olhar para sua própria responsabilidade no crescimento da filha e para se implicar no sintoma alimentar que esta última desenvolveu.

Helena relatou histórico de maus tratos na infância, quando sofreu com o preconceito e o racismo de membros da família, principalmente da avó, que dizia que ela era "suja". Confidenciou que sempre se sentiu diferente: "Pra a família da minha mãe, pra você ser bonito, você tem que ser loiro, de olho azul... Do jeito que é o padrão deles”. Nota-se, portanto, que o sentimento de ser “feia, esquisita” tinha raízes em vivências da infância.

Hipotetiza-se que Helena trazia experiências de muito desamparo na infância, quando se sentia mal tratada pela família extensa e desprotegida pelos pais, uma vez que a mãe tinha a 
saúde debilitada e não podia cuidar dela - pelo contrário, era Helena quem desempenhava o papel de cuidadora -, e o pai que "só falava em dinheiro", ou seja, o pai que não conseguia se aproximar da filha e acolher suas angústias.

\section{O despertar da feminilidade}

Helena teve sua primeira menstruação aos 12 anos de idade, quando passou a sentir-se estranha, como se a menarca configurasse mais uma "responsabilidade", dentre tantas que ela já tinha. Definiu a menstruação como “uma carga, um fardo”. O devir da feminilidade, para Helena, parecia estar associado com enorme sobrecarga: menstruar todo mês, cuidar dos irmãos (ou filhos?), do pai, da mãe adoecida, dos afazeres domésticos, entre outros. Seria a feminilidade um fardo?

[...] Pros meus irmãos as coisas são mais fáceis, eu acho. Eles não têm que ser dona de casa, uma coisa que sobrou pra mim, só por saber que eu sou mulher, eu acho. (Entrevista com Helena)

Apesar de dizer que "não achava ruim ser mulher”, Helena também dizia que "não gostava de ter características femininas”. Logo no início da entrevista, e em vários outros momentos, a participante relatou incômodo com os seios, sendo que o emagrecimento configurava uma tentativa de esconder o corpo e evitar o crescimento dos atributos femininos, dos quais ela tinha muita vergonha. Helena teve dificuldades para justificar o incômodo com os seios:

Não sei, talvez pelo fato de eu não querer ter seio... Porque eu acho que fica feio no corpo, não sei... Me incomoda. Isso começou a me incomodar logo que eu comecei com o transtorno. Antes eu não ligava tanto... Na verdade, eu nunca tive muito corpo feminino assim, sempre fui magra, mas me incomoda isso. (Entrevista com Helena)

O seio também emergiu no relato de Golita: a participante revelou que "aprendeu a ficar mocinha sozinha", pois sua mãe era muito "antiquada" e "não ensinava nada sobre 
isso". Confidenciou que, quando seus seios começaram a crescer, sua mãe dizia que "era doença que tava nascendo”.

É, doença. Minha mãe não falava que era peito que tava nascendo, falava que era doença que tava nascendo em mim. Aí eu ficava apavorada, sabe? Aí eu fui descobrir que era seio conversando com as amigas. Então eu fui descobrindo as coisas sozinha, na rua, brincando com as amigas. (Entrevista com Golita)

A feminilidade e seus símbolos, portanto, vêm sendo inconscientemente associados à doença e transmitidos psiquicamente entre as mulheres da família há pelo menos três gerações. O sintoma de aversão aos atributos femininos, principalmente o seio, surge como duplamente determinados: desejo intenso de emagrecer - e assim, portanto, eliminar tais atributos, e também como identificação inconsciente à mãe e à avó. No ódio ao seio, hipotetiza-se também o repúdio inconsciente à relação com a mãe, tanto em termos de identificação com o gênero quanto da própria vinculação emocional, cuja primeira aproximação se deu por meio do seio da mãe, na amamentação.

Apesar do repúdio aos atributos femininos, Helena apresentava interesse por se vestir bem, estar sempre arrumada e maquiada, o que foi evidenciado tanto pela sua apresentação física quanto pelo interesse por moda e desejo de ser estilista. Pode-se pensar em uma ambivalência em relação ao feminino, que parece ser valorizado nos aspectos externos, mas cuja vivência subjetiva parece insuportável. O apreço pela boa aparência era algo que Golita percebia como diferente entre mãe e filha:

[...] Ela é teimosa, ela tem umas mania que às vezes me desagrada. Ela tem muita mania de comprar coisa que não usa... Ela tem uma mania compulsória de querer comprar sapato sem necessidade, né... E tudo isso a gente tem que relevar, porque tem mulher que tem essa mania, né? [...] Eu não, às vezes é até por isso que eu não suporto, eu sou uma mulher que não tem essa mania de comprar, nem sapato e nem bolsa... E nem roupa. (Entrevista com Golita)

Nota-se, portanto, que sua própria feminilidade não emergia como algo a ser valorizado. Pensando em termos de transmissão psíquica e na importância da identificação 
com a mãe na feminilidade primária (Ribeiro, 2011), a ambivalência de Helena em relação ao feminino pode ser compreendida como expressão da ambivalência do desejo de proximidade com a mãe, sendo que o repúdio ao seio emergia como algo que aproximava mãe e filha, e a (des) valorização da feminilidade (expressa pelo apreço a roupas, maquiagem e autocuidados) como algo que as separava.

O “ser mulher” também emergiu no relato de Helena como uma “carga pesada”, uma vez que envolvia afazeres domésticos, limpeza da casa, preparo das refeições e, ainda, o trabalho fora da casa. Ao ter tido que realizar todas essas atividades em épocas muito precoces da vida, Helena parecia sentir que havia perdido a adolescência e, consequentemente, a possibilidade de viver relacionamentos, sexualidade e prazer. Como já mencionado anteriormente, sentia-se velha, como se sua vida já estivesse acabando. As experiências afetivas de Helena, assim como as percepções e experiências parentais de Golita e Pedro, serão discutidas a seguir.

\section{Relacionamentos afetivos e vida sexual}

O casamento, para Helena, remetia ao "ser dona de casa":

Eu nunca pensei muito nisso, pensava só que eu fosse namorar alguém, mas nunca pensei em casa, assim... Na verdade, eu não quero me casar, porque eu não quero ser dona de casa, eu já fiz muito isso (risos). (Entrevista com Helena)

Nota-se, portanto, que as possibilidades de envolvimento afetivo estavam impedidas no psiquismo de Helena, pois pareciam aproximá-la do "ser mulher", que era equivalente a "ser dona de casa". Helena nunca havia se relacionado afetiva e/ou sexualmente com ninguém, nem mesmo beijado. Quando indagada sobre essa ausência de relações íntimas, a participante relatou que acredita não ser fisicamente agradável para as pessoas, além de se sentir “diferente, feia, estranha, esquisita”. 
Em contrapartida, a mãe contou de um interesse que Helena teve por um garoto no início de sua adolescência, tendo sofrido uma "desilusão" amorosa quando o garoto se envolveu com outra jovem. Segundo o relato de Golita, a filha "não suporta ouvir falar nem o nome, nem dele nem da menina". Inclusive, a participante acredita que foi a partir da mencionada desilusão amorosa que a filha "começou a se pôr defeito" e "falar que estava gorda".

Helena relatou que acreditava que, quando tivesse 24 anos, iria conhecer alguém por quem poderia se interessar, e então iria namorar. No entanto, como a expectativa não foi realizada, a participante preferiu não pensar mais em namoro.

Eu já pensei, hoje não penso mais. Porque não quero me frustrar, eu não penso mais em conhecer ninguém, porque e se não acontecer, né? Então é melhor não pensar nisso. (Entrevista com Helena)

Em relação ao sexo propriamente dito, Helena contou que não pensa no assunto: “Acho que eu tenho tanta coisa na cabeça que não dá espaço”. Sentia-se envergonhada por nunca ter tido relações sexuais, o que, mais uma vez, a diferenciava da maioria das pessoas. Considerava-se “velha demais para nunca ter tido nada com ninguém”.

A ambivalência em relação ao feminino, mencionada anteriormente, também emergiu no relato de Helena quando esta se remeteu ao corpo como algo que poderia "agradar" o garoto por quem foi apaixonada na adolescência. No entanto, mesmo tendo em mente a ideia do corpo como atrativo para o sexo masculino, a participante não conseguia tolerar a imagem de ter um “corpo feminino”.

Ah, sei lá, porque depois acho que ele começou a namorar outra pessoa, mais nova que eu ainda, só que tinha mais corpo que eu. Só que ao mesmo tempo que eu não tinha corpo, eu achava que eu teria que ter corpo só pra conseguir alguma coisa, eu não queria ter, porque pra mim ia incomodar se eu tivesse um corpo feminino. Eu não sei explicar por que. (Entrevista com Helena) 
Acredita-se que a vivência de um “corpo feminino” implica na vivência da própria feminilidade enquanto conjunto de experiências vividas pela mulher na relação consigo mesma, com o outro, e que coloca o corpo como palco das relações. O corpo traz, portanto, as marcas do afeto e do desejo. Helena parece impedida de desejar, de viver o prazer e a sexualidade. Apesar de sentir-se "velha", apresenta-se despreparada para viver o "ser mulher”. Apresenta-se como uma criança indefesa.

[...] Porém, em alguns raros momentos, eu percebia uma semente de afeto, ainda que negativo: quando Helena se referia à saúde prejudicada da mãe, à sua impossibilidade de realizar os afazeres domésticos (que ela então atribuía à filha) e à fixação do pai nas questões financeiras, pude perceber sentimentos de mágoa (e talvez até raiva) de suas origens, que pareciam impedi-la de ter uma vida que ela chamava de "normal". Ao mesmo tempo em que se sentia desprovida de experiências de vida, sentia-se velha demais, em função da quantidade de atividades "adultas" que vinha realizando desde a puberdade. Sentia-se diferente de todos. (Diário de campo, entrevista com Helena)

Trata-se, portanto, de um psiquismo que sofreu violências e que foi impedido de se desenvolver. Segundo Elliot (2010), “a incapacidade de superar experiências passadas resulta em estagnação” (p. 44). Hipotetiza-se, portanto, que a sobrecarga afetiva e a dor mental de Helena ultrapassaram as possibilidades de suas defesas psíquicas, transformando as emoções em atos agressivos direcionados a si mesma (McDougall, 1991), que podem ser observados no corpo esquálido, na intensa restrição alimentar, em sua própria percepção de incapacidade de crescer profissionalmente, na impossibilidade de criar vínculos emocionais, entre outros.

No que concerne à relação conjugal parental, tanto Golita quanto Pedro confidenciaram que não têm tido vida sexual há muito tempo. O distanciamento emocional do casal, já discutido anteriormente, parece ter acarretado um distanciamento também físico. Golita acreditava que o marido fingia que dormia quando ela se deitava ao seu lado, e relatou fantasias de adultério. 
[...] Eu fico cabreira, você entendeu? Fico pensando: "Se não tem aqui em casa, será que não tem fora?". [...] Aí eu fico pensando: "O homem tá de carro, onde que eu vou seguir esse homem a pé? Com essa coluna boa que eu tenho". Então às vezes eu fico pensando: "E se esse homem tá me botando um chifre e eu não tô nem sabendo?”. (Entrevista com Golita)

Golita também descreveu ideias de separação conjugal, e relatou que quando expunha tais ideias ao marido, este falava "que era para ela pegar os filhos e ir embora". Pedro, em contrapartida, sentia-se "sufocado" com os "contratempos" cotidianos, principalmente relacionados ao aspecto financeiro da família. Tais contratempos emergiram no relato do participante como motivos de muitas brigas entre o casal, além do “abandono” da relação após o nascimento dos filhos.

Tanto Golita quanto Pedro demonstraram ter restrições para falar sobre sua vida íntima, assim como para tratar de assuntos relativos à sexualidade com Helena. Pedro perguntou várias vezes à pesquisadora a respeito de qual era seu papel enquanto pai:

Ah, nunca me interessei, sinceramente. Isso é uma função do pai? Que que você acha? [...] Eu acho que não. Tendo uma mãe presente... [...] Ah porque eu acho assim, né, que a filha sempre vai se abrir mais com a mãe, né? Eu acho, eu acho. Se você não vai dar essa resposta eu não vou ficar sabendo qual é o outro lado, né (risos). (Entrevista com Pedro)

Nota-se que Pedro não conseguia se aproximar de questões íntimas da filha, acreditando que tais questões deviam ser cuidadas pela mãe. Por fim, Helena apresentou percepção semelhante à de sua mãe no que diz respeito à valorização de Pedro aos aspectos financeiros da família.

Meu pai, até com a minha mãe assim, ele cobra muito dinheiro. Ele não é um pai muito presente, de uma recreação com a família... De ir conversar... Mas ele sempre foi assim. Então eu não sei... Eu não sei se eu queria um casamento assim, sabe. $\mathrm{Na}$ verdade, eu acho que eu não queria um casamento, mas se fosse pra ser assim, eu também não queria, não. (Entrevista com Helena) 


\subsubsection{Família Teixeira}

Maria, a filha: "Foi estranho ver como a minha vida mudou por causa desses atributos femininos”

Maria, a mãe: "Sabe por que a gente briga? Porque eu sei tudo de você e você sabe tudo de mim”

Lorival, o pai: "Eu acho que ela gosta mais de mim que da mãe dela"

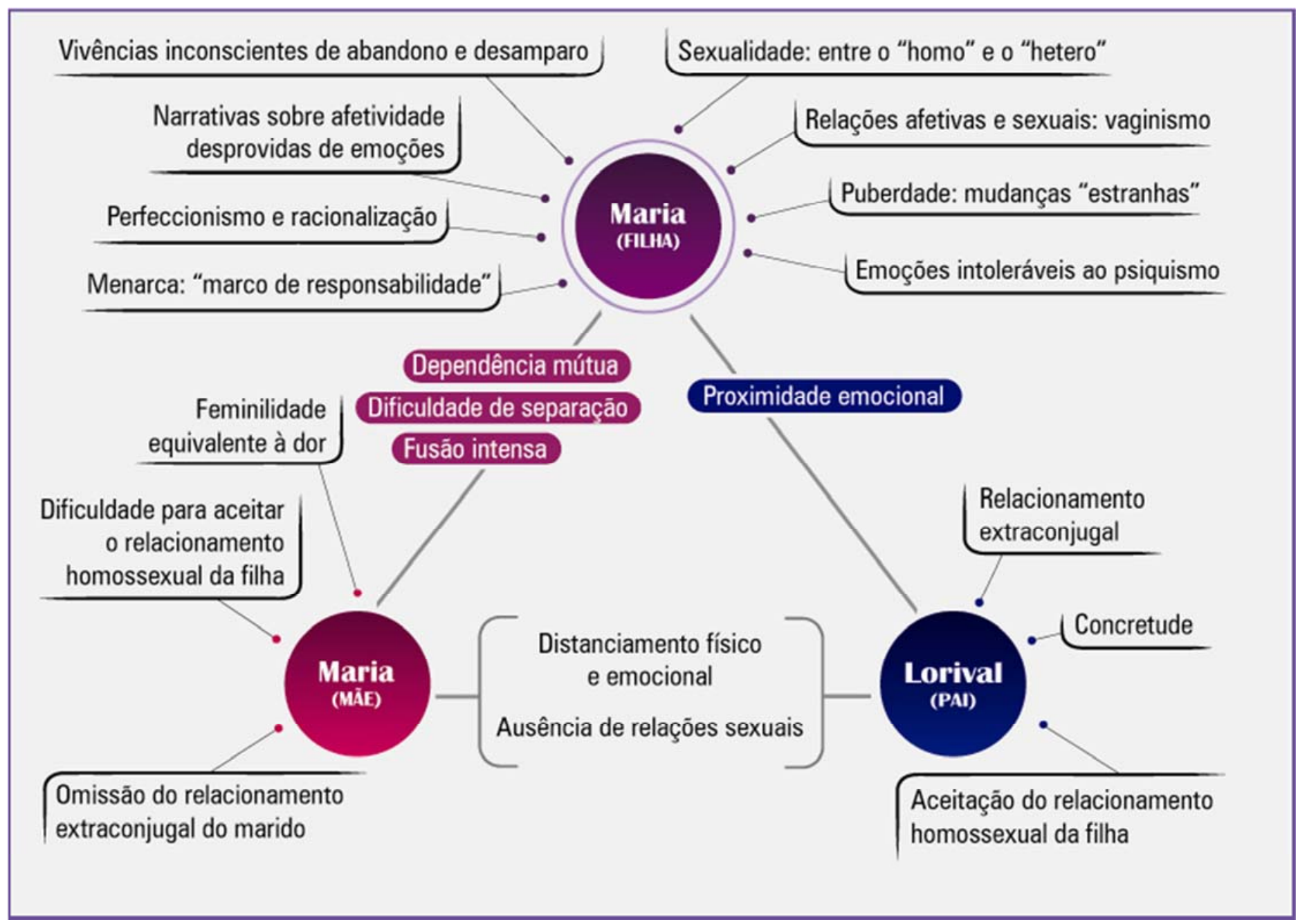

Figura 5. Mapa de associação de ideias da família Teixeira. 
Maria (filha) iniciou o tratamento no GRATA no ano de 2011, aos 20 anos de idade, após uma internação de três meses no serviço de Psiquiatria da instituição hospitalar onde o presente estudo foi conduzido. Apresentava grave perda de peso, com intensa distorção da imagem corporal. Pesava 39,1 kg, $1,53 \mathrm{~m}$ de altura e $\mathrm{IMC}=16,7 \mathrm{~kg} / \mathrm{m}^{2}$, indicando desnutrição. A equipe de Psiquiatria atribuiu-lhe o diagnóstico de AN do tipo purgativo e transtorno de personalidade narcisista. Este último, segundo o DSM - V (American Psychatric Association, 2013), envolve autoestima variável e vulnerável, com tentativas de regulação por meio da busca de atenção e aprovação, e grandiosidade declarada ou encoberta.

No momento da entrevista, Maria (filha) estava com 24 anos de idade e encontrava-se fisicamente bastante diferente do início do tratamento no GRATA. Havia ganhado peso $(\mathrm{P}=$ 53,7 kg, $\mathrm{A}=1,53 \mathrm{~m}$ e IMC $=22,9 \mathrm{~kg} / \mathrm{m}^{2}$ ), alisado os cabelos (que anteriormente eram curtos e enrolados) e aparentava mais maturidade. Em contrapartida, mantinha a firmeza na fala, a inteligência e a racionalidade que havia apresentado logo no início do tratamento.

Durante a entrevista, percebi que Maria apresentava explicações bastante racionais de suas próprias vivências, e tive fantasias de que tais explicações eram provenientes de suas leituras e seus anos de terapia. No entanto, pensei que tais explicações eram bastante distanciadas de suas emoções, pareciam até um pouco "mecânicas", algo "pronto”, proveniente de fontes externas. (Diário de campo, entrevista com Maria filha).

Segundo os dados do prontuário hospitalar, o diagnóstico de AN do tipo purgativo de Maria (filha) estava sendo revisto, uma vez que a participante encontrava-se eutrófica e os vômitos eram associados à momentos de angústia, e não à compulsão alimentar (que ocorria de forma bastante esporádica). O diagnóstico de transtorno de personalidade narcisista ainda estava em vigor.

A renda familiar, segundo o relato do pai, era de aproximadamente 4.600,00. No entanto, a pontuação no CCEB/2015 indicou que a família se encaixa no estrato socioeconômico B1, que compreende rendas de aproximadamente oito mil reais. 


\title{
O transtorno alimentar
}

Segundo Maria (filha), o TA está relacionado a sentimentos de ansiedade, tristeza e desânimo, que podem resultar na perda da fome ou na compulsão alimentar, “como uma forma de se dilacerar, de se punir”. Geralmente tais sentimentos são oriundos da impossibilidade de "atingir expectativas, atingir metas", o que faz com que Maria (filha) sinta-se frustrada e "perdida”. De forma bastante racionalizada, Maria (filha) descreveu suas tentativas de lidar com conflitos emocionais:

\begin{abstract}
Ah... Leitura, me desapegar da matéria, me desapegar disso que, que... Que eu sou materialmente, me lembrar de momentos que eu vivenciei muito bons e que não importavam se naquele momento eu estivesse magra, gorda, preta, branca, cabelo longo, curto, enrolado, liso... Não importava... Lembrar desses momentos, refletir sobre isso, pensar que essas conquistas significativas que eu fiz na minha vida, elas não estão relacionadas, nunca estiveram, ao meu corpo... (Entrevista com Maria filha)
\end{abstract}

Maria (mãe) relatou que, no início do aparecimento dos sintomas, “estava cega”, pois “não enxergava o peso, o número de quilos que ela [filha] havia perdido". Começou a perceber que a filha estava sentindo tonturas e passou a "ficar mais perto dela". Notou que a filha passou a trancar a porta quando entrava no banheiro ("Eu nunca gostei que trancasse o banheiro") e a ficar muito tempo lá dentro. Uma das vezes em que insistiu para que a filha saísse do banheiro, percebeu o cheiro de vômito e começou a pensar na possibilidade “dela ter bulimia”. Após três desmaios da filha, levou-a ao hospital, onde permaneceu internada durante três meses e iniciou o tratamento no GRATA.

Algo muito marcante para Maria (mãe) foi ter visto a filha nua, tão emagrecida.

Eu achei que eu fosse perdê-la, porque ela já estava muito magra, e elas não deixam a gente vê-las sem roupa, nua né, então a primeira vez que eu vi foi pra mim, assim, foi um horror, um verdadeiro horror. [...] Pra mim foi um horror, assim... É uma visão que eu acho que se eu viver mais cem anos eu acho que eu não vou esquecer. (Entrevista com Maria - mãe) 
No momento da entrevista, Maria (mãe) ainda tinha muita dificuldade de aceitar “o número de vezes que ela (a filha) come, a quantidade de comida que ela come, o número de vezes que ela vai ao banheiro". Relatou que se sente "extremamente irritada”, apesar de saber que a filha ainda estava doente e em sofrimento. Sentia-se impotente vendo o sofrimento da filha e gostaria que existisse "um remédio, uma força que tirasse isso dela".

Lorival contou que a alimentação sempre foi prioridade em sua casa, devido às muitas dificuldades financeiras que passou na infância. Sentia vontade de comer alguns alimentos principalmente doces - que não podia, pelo fato de não ter dinheiro suficiente. Portanto, sempre criou as filhas para "comer bem mesmo, comer bastante”. Percebeu que a filha estava comendo compulsivamente quando a família fez uma viagem à praia e puderam passar alguns dias juntos, pois trabalhava muitas horas por dia e mal via a filha. Apesar disso, Lorival relatou que "sempre sabia quando Maria (filha) não estava bem, quando estava mentindo", mas preferia esperar que a filha contasse o que estava acontecendo, pois a considera agressiva e "não era bom bater de frente".

Lorival atribui o início dos sintomas sugestivos de perturbação do comportamento alimentar ao primeiro relacionamento afetivo da filha, que foi homossexual. Tal relacionamento será melhor descrito posteriormente.

\section{As relações familiares}

Tanto o pai quanto a mãe descreveram Maria (filha) como agressiva, especialmente quando tentam corrigir ou criticar algo em seu comportamento. Lorival relatou ser "mais duro com ela, não dá moleza", e acreditava que essa forma de lidar com a filha fazia com que ela “gostasse mais dele do que da mãe”, pois mesmo depois de uma briga, “já estavam os dois ali ‘juntado’”. Nota-se que, segundo o discurso do pai, Maria (filha) necessitava que o pai exercesse a função de interditor para "segurar" sua raiva. 
A relação entre mãe e filha era permeada por intensa fusão, o que pode ser observado logo de início pela escolha de cada uma para os nomes fictícios: ambas escolheram o nome "Maria”. A filha não atribuiu motivo à escolha do nome, enquanto que a mãe justificou a escolha ao fato de se tratar do nome de sua própria mãe, demonstrando a presença de conteúdos identificatórios de ordem transgeracional. Nota-se que dentre as mulheres da família Teixeira há um enlace do singular e do transgeracional na elaboração da imagem psíquica, que parece estar alienada à relação com a figura materna (Azevedo, Fères-Carneiro, \& Lins, 2015).

O nome "Maria” remete às santas da Igreja Católica, cujos jejuns intensos estavam relacionados à busca de um estado puro e ao cumprimento de penitências que sempre se renovam (Miranda, 2011). Partindo-se da observação da existência de uma relação fusionada entre mãe e filha, hipotetiza-se que tais penitências sejam oriundas da culpa inconsciente pelo amor profano pela mãe.

Porque minha mãe é muito casta, santa, né... Tem toda essa coisa de religião... (Entrevista com Maria - filha)

Em contrapartida aos jejuns, há os episódios de compulsão alimentar, que parecem ser a única via de expressão da agressividade e da voracidade de Maria (filha), uma vez que os aspectos de sexualidade são punidos e reprimidos, como será exposto posteriormente.

Além da escolha do nome, o discurso de Maria (mãe) trouxe várias nuances que ilustram a fusão existente entre mãe e filha. Ainda que na relação estejam presentes muitos sentimentos de carinho e preocupação mútuos e genuínos, também foi possível notar a dificuldade da mãe para tolerar as diferenças entre ela própria e a filha: o modo da filha se alimentar, o número de vezes que ela vai ao banheiro, o tempo que ela despende tomando banho, entre outros, eram motivos de muita raiva para a mãe. Evidencia-se o quanto é difícil para a mãe tolerar não saber o que a filha faz dentro do banheiro e longe dela: "Eu nunca 
gostei que trancasse o banheiro". Proximidade e intimidade muitas vezes extrapolavam o limite da individualidade e geravam sentimentos de ódio. Em contrapartida, ao sair da mesa de jantar e trancar-se no banheiro, Maria (filha) endereçava algo aos pais, que parecia legitimar as vezes em que a mãe precisou arrombar a porta.

Somos muito parecidas. Eu acho que, ela fala: "Sabe por que a gente briga? Eu sei tudo de você e você sabe tudo de mim”. (Entrevista com Maria - mãe)

A relação entre mãe e filha foi descrita pelas duas como “muito próxima”, de "muita amizade", mas "não dependente”. Porém, tal proximidade parece ter sido quebrada quando a mãe descobriu sobre o relacionamento homossexual da filha, que será posteriormente discutido.

Para Maria (filha), os pais são afetivamente “frustrados”. São “companheiros, amigos, mas a vida sexual deles não existe”. Apesar de certa relutância da mãe, Maria (filha) tentava conversar sobre a vida afetivo-sexual dos dois, que de certa forma se tornou acessível às filhas depois da descoberta de um relacionamento extraconjugal de Lorival.

No ano passado, no primeiro semestre do ano passado, apareceu uma mulher falando que tinha uma filha do meu pai, de 15 anos. E aquilo foi: "Quê? Oi?" (risos), porque meu pai, meu... Meu pai, sabe? Meu pai não é: "Ah gostosa”. O meu pai é sossegadão, sabe? Meu pai é família, assim, entendeu? Minha mãe também, assim... Enfim... (Entrevista com Maria - filha)

A filha contou que o pai se relacionou sexualmente com a mulher uma única vez, e não quis assumir a criança quando ela contou que estava grávida, então deu-lhe dinheiro para que ela realizasse um aborto. Quando Maria (filha) adoeceu, Lorival acreditava que a culpa era dele, como algum tipo de punição por ter permitido que a mulher abortasse seu filho. Maria (filha) contou que a mãe se sentiu muito traída, mas que a experiência serviu para que ela se posicionasse de uma forma diferente no relacionamento, expondo mais seus desejos. 
Ao relatar o relacionamento extraconjugal do pai, a filha não expressou sentimento algum, pelo contrário: seu discurso foi emocionalmente distanciado, sem expressão de raiva, tristeza ou qualquer outra vivência. Lorival e Maria (mãe) não mencionaram o relacionamento extraconjugal em suas respectivas entrevistas. Lisboa e Féres-Carneiro (2015), a respeito de acontecimentos significativos dentro da família, propõem que esses acontecimentos, quando não elaborados ou superados ao longo da história familiar, dão origem a construções intersubjetivas silenciosas e aniquiladoras, as somatizações. Nota-se que os três membros da família evitaram entrar em contato com as angústias que poderiam ser geradas a partir do relacionamento extraconjugal de Lorival: os pais não mencionaram o acontecimento, e Maria (filha) descreveu o acontecimento de forma racionalizada e distanciada, sem se aproximar dos sentimentos negativos que tal acontecimento teria gerado. Portanto, o relacionamento extraconjugal de Lorival configura um acontecimento significativo e não elaborado dentro da família Teixeira.

\section{O despertar da feminilidade}

Maria (filha) teve sua menarca aos nove anos de idade. Para ela, o acontecimento foi “uma bosta”, pois sentia-se "privada de sua liberdade”: "Eu queria andar de bicicleta, queria nadar! (risos)”.

Mas, nossa, eu ficava puta da vida, e depois disso começou a crescer tudo... Peito, quadril, tudo ficou diferente, assim, sei lá. Eu sei, foi uma coisa que me alterou muito, a menstruação, sabe? Não foi simplesmente um sangramento, assim, hormonalmente, é uma coisa que me alterou bastante, sabe? Preferências, eu fiquei mais séria, sabe coisa que me alterou bastante, sabe? Eu fiquei menos espalhafatosa, assim, fiquei mais séria, mais centrada, não sei explicar... Foi um negócio meio bizarro. (Entrevista com Maria - filha)

A participante considerava que a menarca havia sido um "marco de responsabilidade”, pois na mesma época estava iniciando o sexto ano do Ensino Fundamental 
e sentia-se com muitas responsabilidades novas. Relatou que chorava todo mês quando menstruava, "era um Deus nos acuda". Nota-se, portanto, que a participante estava vivendo um intenso processo de luto pela infância, que estava sendo deixada para trás.

A mãe relatou que a filha havia menstruado aos 11 anos de idade, "exatamente como foi com ela”. Contou que ela "entrou no banheiro, se trancou no banheiro, chorou bastante”. Quando questionada a respeito do sofrimento da filha, Maria (mãe) atribuiu motivos bastante concretos: lembrou-se de que quando as filhas tinham 11 e nove anos, levou-as ao médico e este informou-lhes de que quando as filhas menstruassem, parariam de crescer. As duas eram “pequenininhas como a mãe”, e quando Maria (filha) menstruou, a mãe acreditou que o choro se devia ao fato de que ela não cresceria mais.

Maria (mãe) também confidenciou suas próprias dificuldades com a menstruação e outras questões relacionadas à sexualidade feminina. Contou que sempre teve cólicas menstruais muito fortes, precisava sempre faltar do trabalho e ir ao hospital. No entanto, relatou que as cólicas cessaram assim que teve a primeira filha, como se a maternidade trouxesse algum tipo de resolução para as dores do feminino. Para Freud, o "tornar-se mulher” era equivalente ao "tornar-se mãe”, atribuindo ao filho e ao exercício maternidade à identidade feminina (André, 1998). Porém, autores mais contemporâneos, como Iaconelli (2014) e André (1998), propõem que o enigma do feminino não encontra resolução com a vinda de um filho: a ferida narcísica decorrente da castração continua permeando o imaginário das mulheres, mesmo das mães. Dependendo da intensidade dessa ferida e das condições internas da mãe de lidar com seus “vazios”, podem ou não existir dificuldades na relação mãe-filha e no processo identificatório da filha com a mãe enquanto mulher.

Em função das cólicas, Maria (mãe) tomava um medicamento (Cicloprimogyna, que não tem efeito contraceptivo), e um dia esqueceu acidentalmente o medicamento em cima do armário, e o pai viu. 
Eu quase apanhei do meu pai, porque ele, ele falou que era anticoncepcional, e eu negava, porque não era mesmo né, era remédio de cólica menstrual. Então você vê, a gente não podia falar nada, né, porque isso aí, a gente tinha que casar virgem, não podia engravidar antes de casar... (Entrevista com Maria - mãe)

Apesar de não ter se casado virgem, Maria (mãe) contou que teve relação sexual com o noivo apenas quatro meses antes do casamento, e contou que "foi muito bom, mas com muito medo do pai, morria de medo do pai e da mãe”. É possível perceber que o "ser mulher”, para a mãe, vinha acompanhado de muitas dores, tanto físicas quanto emocionais. Havia as dores das cólicas, e também a responsabilidade de “casar virgem”, a dor de decepcionar o pai e de apanhar por isso.

Lorival soube da menarca da filha pela esposa, mas depois ouviu da própria filha. Em um discurso bastante gracejado, contou que quando as mulheres da casa estão brigando, prefere sair e voltar depois de bastante tempo. Sendo o único homem da família, sentia-se em desvantagem: "Daí junta as três, mesmo que eu tiver certo, elas ficam do lado da mãe (risos)"'.

O pai presenciava o sofrimento de Maria (filha) em relação à menstruação, e atribuía ao incômodo que esta sentia para usar absorvente. Nota-se que Lorival fazia uso da concretude para explicar questões íntimas da filha, das quais não se aproximava.

\section{Relacionamentos afetivos e vida sexual}

O primeiro relacionamento afetivo e sexual de Maria (filha) foi homossexual, com uma amiga de infância muito próxima.

Começou tudo de uma brincadeira, eu não lembro muito bem como foi, mas uma história de personagens, que eu era um personagem masculino, assim, pra ela... E ela era um personagem feminino. E isso foi, foi brincando disso, assim, brincando, brincando, brincando mesmo [...] A gente percebeu que, eu pelo menos percebi, que aquilo foi se tornando realidade, aquele relacionamento que eram personagens às vezes, e às vezes não [...] Isso foi evoluindo, foi evoluindo, e a gente começou a se beijar mais frequentemente, e a ficar mais frequentemente, a ficar muito junto, $e$ 
tudo mais... E... A gente fez sexo. E... E aí eu vi que era muito bom mesmo, e que eu gostava daquilo e assumi pra mim: "Eu gosto disso e fim". (Entrevista com Maria filha)

Esse relacionamento durou aproximadamente sete anos, mas Maria (filha) não conseguia definir se era de fato um relacionamento, pois a incorporação de "personagens" durante o sexo como única forma de estarem juntas fazia com que a participante relativizasse a forma de "estarem juntas": "Acho que no começo ela até estava comigo, mas depois ela não tava comigo, ela tava com os personagens que ela me pedia pra fazer, e que eu fazia porque era a única forma de eu tê-la". No momento da entrevista considerava que havia sido uma relação de “dependência, de obsessão gigante”.

Maria (filha) e M. esconderam seu relacionamento por quase três anos, até uma véspera de Natal em que suas mães estavam juntas na sala da casa de Maria conversando, juntamente com as filhas, uma outra amiga delas e a irmã de Maria (filha). Em um dado momento, a amiga - que Maria (filha) caracterizou como "sem noção, inocente demais" disse: “Só vocês não percebem que elas se amam, né?”. Com essa revelação, Maria (mãe) começou a chorar e falou coisas que entristeceram a filha, tais como: “Não fala nada perto do seu pai e da sua irmã, não quero que eles fiquem sabendo dessa pouca vergonha, dessa barbaridade”. Além disso, Maria (filha) sentiu-se entristecida com o fato da mãe ter "repetido umas cinquenta vezes que a filha havia acabado com o Natal dela, com a vida dela”.

Apesar de ter "internalizado que aquilo faria mal para a mãe, para o pai e para o mundo", na época da entrevista Maria (filha) sentia-se mais à vontade para reconhecer que sentia atração tanto por homens quanto por mulheres. Havia terminado um namoro com um jovem há cinco meses, com quem teve sua primeira experiência heterossexual.

Bom, terminei porque não deu certo, é... A minha vida sexual com ele, porque ele tinha um problema, uma dificuldade, e eu não consegui lidar com essa dificuldade dele, não consegui lidar bem, e precisei terminar o relacionamento para me sentir bem, enfim... Ele tinha uma necessidade de sexo muito grande e queria sempre fazer 
sexo e sofria uma transformação muito grande, ele se transformava em outra pessoa no momento do sexo. [...] Ele ficava uma pessoa séria, uma pessoa muito fogosa, uma pessoa... Com expressões, assim, que me assustavam um pouco, e com atitudes também, muito invasivo também, ele era muito invasivo [...] (Entrevista com Maria filha)

Maria (filha) repetiu que “se sentiu invadida” várias vezes enquanto contava do relacionamento que teve com o jovem em questão. Apesar de ter sentido vontade, desejo e prazer, “foi estranho ver a transformação que ele sofria” durante o ato sexual. É possível perceber o quanto Maria (filha) se assustava com aspectos primitivos e animalescos do ser humano, tais como voracidade e desejo sexual.

As relações sexuais com o ex-namorado passaram a ser cada vez mais difíceis e doloridas, pois a participante desenvolveu uma condição clínica que nomeou como “vaginismo".

Na verdade a gente não chegou a... Não conseguiu chegar a ter uma relação sexual, ter a penetração em si, porque eu desenvolvi vaginismo, e aí... Eu não conseguia relaxar de forma alguma, e quando eu pensava que eu tava relaxada, eu tava... Nossa! Extremamente tensa e contraída e aquilo não ia de jeito nenhum. (Entrevista com Maria - filha)

A atribuição de uma condição clínica às suas dificuldades sexuais remete à racionalização de Maria (filha), já mencionada anteriormente, como expressão da impossibilidade de se aproximar de conteúdos angustiantes e potencialmente desestruturantes. O "vaginismo" ilustra que a participante não se deixa penetrar, ilustração esta que também pode ser estendida à racionalização: nada penetra, nem pênis, nem afetos. Ter um outro com desejo, que quer colocar algo dentro dela, parece ser assustador, uma vez que seu próprio desejo permanece controlado e inacessível. Pode-se interpretar que o lado primitivo e animalesco de Maria (filha) é direcionado apenas para a alimentação, na forma de episódios de compulsão. 
Para a mãe, a revelação do relacionamento homossexual da filha fez com que as duas (mãe e filha) se separassem, pois não aceitava a ideia de ver a filha namorando uma menina. Antes desta revelação, as duas eram muito próximas, “não dependentes, mas muito amigas”, e então se afastaram. Com o tempo foram recuperando a proximidade, mas Maria (mãe) confidenciou que ainda teria dificuldade para aceitar se a filha decidisse namorar uma menina. Lorival, em contrapartida, revelou-se entristecido pela filha não ter-lhe confidenciado a respeito do namoro com a amiga. Relatou que percebia que havia algo diferente acontecendo com a filha, mas acreditava que, se ela precisasse de algum tipo de ajuda, iria procurá-lo. Maria (filha) surpreendeu-se com esta reação do pai, tendo percebido nele um apoio que não sabia que tinha.

Alguém disse para a minha esposa [sobre o relacionamento homossexual da filha]. E eu, já... Sabe, já sentia alguma coisa. Minha esposa nesse sentido ela já é lenta. Mas se amanhã tiver que acontecer mesmo, quando aconteceu a primeira vez ela [filha] não tinha ficado doente nem nada, quando eu soube, eu pra mim seja feliz do jeito que a pessoa pode ser. [...] Eu percebia que elas tavam muito junto, entendeu? Mas assim, sabe quando você quer acreditar, você não quer, você não tem certeza, então né... Não falei nada. (Entrevista com Lorival)

Em relação à sexualidade do casal parental, tanto Maria (mãe) quanto Lorival atribuem a ausência de relações sexuais à causas concretas, tais como a retirada do útero da esposa e a diabetes do marido, que acreditavam estar relacionada à impotência. Para Maria (mãe): “Ele não tem disposição nenhuma”, e para Lorival, “Nem eu, nem ela [temos vontade]. Vontade eu tenho, assim, tal, isso, aquilo, mas aí chega, ela tá cansada, eu entendo... Tô cansado, trabalho o dia inteiro, depois chega em casa, vai fazer jantar, isso, aquilo”.

Durante a entrevista pude perceber que Maria evitava se aproximar de sua própria sexualidade e conjugalidade: falava da sexualidade da filha $e$ de todas as dificuldades que vivenciava para aceitar a homossexualidade desta, mas não mencionou o relacionamento extraconjugal do marido, do qual eu soube no ano de 2012 devido à minha participação no GRATA. Sempre que se referia à sua própria sexualidade ou à do marido, Maria utilizava fontes concretas, tais como a dificuldade de ereção do marido devido aos medicamentos para diabetes. (Diário de campo, entrevista com Maria - mãe) 
Ele não tem disposição nenhuma. Inclusive eu falei: "A gente tem que saber se é o remédio da diabetes", que ele toma uma dose muito grande né, de remédio. E ele sempre foi assim, desde quando a gente casou, qualquer problema que ele tivesse, ele já, já... Não funcionava mais, sabe. Abalava. Sempre foi assim. E agora piorou, já tem muito tempo que a gente não se relaciona. (Entrevista com Maria - mãe)

Vou falar a verdade, se for pra sair fora do casamento, eu saio todo dia, não sei ela se ela fosse experimentar fora. Acho que é por isso hoje que eu ponho na minha cabeça que existe muita traição, isso, aquilo... Eu acho que chega num ponto, ou você tem que aguentar ou se você quer ser machão você tem que provar lá fora, ou então você judiar da esposa. (Entrevista com Lorival)

Maria (mãe) relatou que o marido era muito “fechado" e que não conseguia conversar com ele a respeito da vida sexual dos dois, mas confidenciou que se afastaram emocionalmente, sem atribuir um motivo específico ou uma fase da vida em que esse afastamento tenha começado a ocorrer.

É muito difícil, ele tem vergonha disso, Só que vergonha, não é vergonha, a gente tem que procurar ajuda, né? Então. Só que eu acho assim, que a gente se distanciou bastante. Por exemplo, de... Como eu acabei de falar, ele gosta de ver televisão, e mesmo que ele não esteja vendo nada, eu me preocupo mais ainda, porque como pode uma pessoa estar de frente para a televisão e você perguntar: "O que eles estão falando?", e eu faço isso sempre com ele, e as minhas filhas também, e ele fala: “Ah, eu nem estava prestando atenção". Sabe? É preocupante. E aí o que acontece, ele não conversa comigo e eu fico assistindo lá quieta. Eu puxo assunto, sabe? (Entrevista com Maria - mãe)

Lorival acreditava que o relacionamento sexual do casal havia sido comprometido pela preocupação com as filhas e pelas atividades cotidianas, que geravam muito cansaço.

Difícil ficar os dois só, viu! É muita preocupação! Você chega uma época que é ansiedade... A C. prestou agora para fazer mestrado, a gente sofre junto, porque agora até semana que vem para saber o resultado... A Maria [filha] nessa pendência aí, a gente se preocupa muito... A gente vive hoje para as duas meninas! (Entrevista com Lorival)

A preocupação estava presente no discurso de ambos, seja da esposa em relação ao marido, ou do marido em relação às filhas. No entanto, o fato de nenhum dos dois haver mencionado o relacionamento extraconjugal de Lorival pode ser indicativo de que o 
afastamento emocional do casal esteja relacionado também a outros motivos, possivelmente oriundos da própria dinâmica do vínculo estabelecido entre eles.

Me chamou a atenção o fato de que nenhum dos dois, pai e mãe, mencionaram o relacionamento extraconjugal de Lorival, do qual eu já sabia devido à minha participação no GRATA e do fato de Maria (filha) tê-lo mencionado em sua entrevista. Ao final das entrevistas com os pais, fiquei com a sensação de que não havia compreendido muito bem a dinâmica do relacionamento do casal, como se o segredo da traição - dentre outros motivos - estivesse anuviando a relação, a ponto de que eles tivessem dificuldade de localizar e expressar o que acontecia entre eles. Contratransferencialmente, também me senti anuviada. (Diário de campo, entrevista com Lorival)

Trata-se, portanto, de um casal que guarda um segredo que reverbera diretamente em suas vivências afetivas e sexuais. As explicações racionais de Maria (mãe) e Lorival para a ausência de relações sexuais podem ser compreendidas como mecanismos de defesa inconscientes contra a dor e a culpa pelo relacionamento extraconjugal. 


\subsubsection{Família Ribeiro}

Gabriela, a filha: "Sei lá, às vezes acho que sou fora do comum"

Rebeca, a mãe: “Os meninos não me chamam de mãe”

Ronaldo, o pai: "A gente fica como cinco irmão dentro de uma casa”

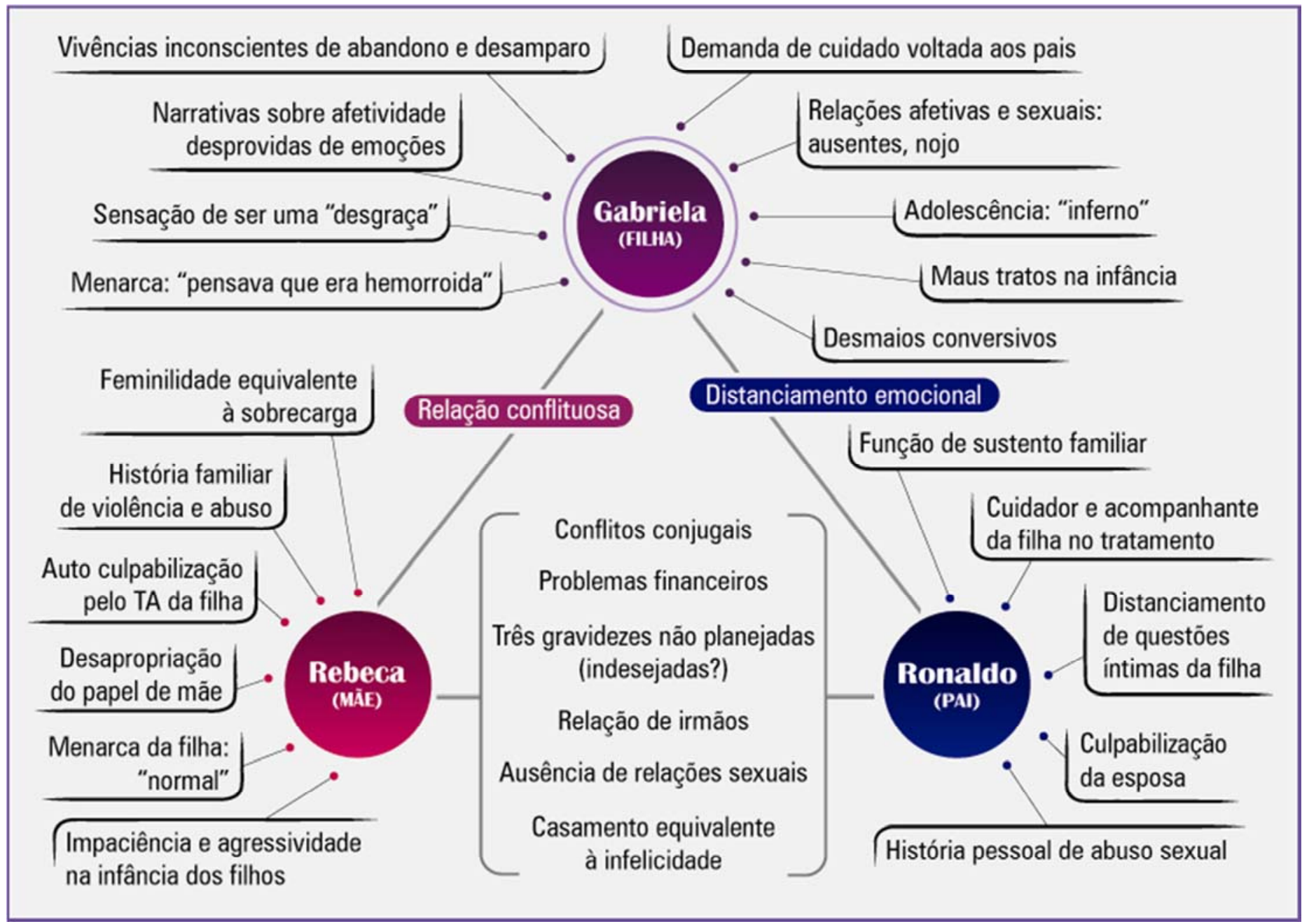

Figura 6. Mapa de associação de ideias da família Ribeiro. 
Gabriela iniciou o tratamento no ano de 2013, quando tinha 17 anos. Pesava 45 kg, tinha $1,71 \mathrm{~m}$ de altura e IMC = 15,5 kg/m², indicando desnutrição. Sentia tontura e fraqueza, e tinha desmaios recorrentes, sem causa orgânica. Recebeu diagnóstico de AN do tipo restritivo. Chegou ao GRATA após internação no serviço de Psiquiatria, ao qual foi encaminhada pelo Juizado de Menores, após denúncia de negligência feita pela escola onde Gabriela estudava.

A esse respeito, os pais relataram nas respectivas entrevistas que desde quando Gabriela começou a apresentar os desmaios, levavam-na ao posto de saúde e a médicos do convênio que ofereciam tratamentos ineficazes, pois a filha continuava desmaiando. Um dos médicos do posto de saúde fez um encaminhamento para o Hospital das Clínicas, pois acreditava que Gabriela apresentava sintomas psiquiátricos e precisava ser tratada em hospital terciário. No entanto, a paciente foi colocada na fila de espera e até aquele momento não havia sido chamada para o tratamento. Durante uma viagem da escola, Gabriela teve um desmaio e os professores precisaram acionar os bombeiros. Estes disseram que, se ela não fizesse um tratamento adequado, morreria. Após esse acontecimento, sob a ótica de Ronaldo, a escola acusou os pais de "negligentes" e acionaram o conselho tutelar, que conseguiu que Gabriela fosse atendida no Hospital das Clínicas mais rapidamente. Ronaldo sentia-se bastante injustiçado com as acusações de negligência que recebeu da escola, pois considerava que havia feito tudo que estava a seu alcance para cuidar da filha.

Na época da entrevista, Gabriela tinha 18 anos de idade e estava em tratamento no GRATA há aproximadamente um ano. Havia tido ganho ponderal de 12 kg (57,3 kg), e apresentava IMC de 19,6 kg/m². Havia terminado o ensino médio e não estava estudando nem trabalhando. Morava na casa com seus pais e dois irmãos, sendo um mais velho (20 anos) e um mais novo (17 anos). A família tinha uma renda mensal de aproximadamente 2.500,00 reais, encaixando-se no estrato socioeconômico C1 do CCEB/2015. Trata-se de uma família com bastante dificuldades financeiras, uma vez que a renda mencionada é utilizada para sustentar cinco pessoas. 


\section{O transtorno alimentar}

Antes de iniciar o tratamento no GRATA, a participante teve uma internação no ambulatório de Psiquiatria que durou três meses e 14 dias, e foi bastante traumática.

Ah eles ficavam me amarrando, toda hora davam injeção em mim, sei lá. Eles ficavam meio bravos comigo [...] Só porque às vezes eu ficava um pouco nervosa, mas é porque eu queria ir embora e não tinha jeito [...] Teve uma vez que eu peguei um copo de leite e taquei longe, sei lá, tipo assim, chutava as coisas. (Entrevista com Gabriela)

Quando questionada a respeito dos momentos de “nervosismo", Gabriela dizia, de forma bastante vaga, que desejava voltar para a escola. Sempre foi uma aluna dedicada e gostava de estudar. Não forneceu muitas explicações a respeito do emagrecimento que teve naquela época, relatando apenas que passava muito tempo estudando e ajudando em casa, e “deixava de comer”. Segundo o relato da participante, a sensação de estar gorda não foi o que motivou a perda de peso, pois esta sensação só apareceu após o emagrecimento.

No momento da entrevista, Gabriela relatou que não considerava que tinha um TA, pois "seu corpo estava normal e estava comendo bem". Sentia-se ainda um pouco acima do peso, mas não se identificava com as outras pacientes do GRATA e achava muito difícil participar das atividades propostas pela equipe.

Ah, porque, tipo... Se eu não considero que eu tenho isso, né, então pra mim eu considero que é perda de tempo, né? Sei lá. Eu acho que eu poderia, acho que tem pessoas que precisam muito mais do que eu, e eu nunca precisei. (Entrevista com Gabriela)

Gabriela acreditava que a única coisa que precisava para se sentir melhor era receber alta do GRATA e parar de tomar os medicamentos psiquiátricos. A participante demonstrava muita desesperança e descrença em qualquer tipo de ajuda, como se apenas “sumir" pudesse trazer algum alívio.

Sei lá. Eu, assim, por mim eu abandonaria tudo, sumia, sei lá. É o jeito. (Entrevista com Gabriela) 
Durante toda a entrevista com Gabriela, ela me lembrava um vulcão prestes a explodir: queria parar de tomar os remédios, parar o tratamento... Como se fosse jogar tudo para o alto, explodir, com a ideia fantasiosa de que os problemas acabariam junto com a finalização forçada do tratamento. Em vários momentos ficava vermelha, com os olhos marejados e a boca trêmula, mas falava de modo bastante ríspido e defensivo. Senti que havia muita coisa acontecendo dentro dela, mas não conseguia confiar em mim - ou em qualquer outra pessoa - para falar. Foi uma entrevista angustiante, que me despertou vontade de cuidar, fazer alguma coisa por ela. (Diário de campo, entrevista com Gabriela)

Rebeca relatou que Gabriela “sempre foi difícil para comer”: colocava a comida na boca dela, mas não engolia. Não percebeu quando o TA da filha começou a aparecer, pois estava muito preocupada com os desmaios que ela estava tendo na escola (que serão melhor descritos a seguir). Levou a filha em vários médicos do convênio, mas não estava conseguindo descobrir a causa dos desmaios. Assim como Ronaldo, Rebeca também sentiu-se injustiçada por ter sido chamada de negligente pelos profissionais da escola, pois levava a filha em vários médicos e acreditava que estava fazendo tudo o que podia, "sempre cuidou bem, sempre foi atrás”.

Durante a infância dos filhos, Rebeca contou que perdia a paciência com frequência, mas principalmente quando estes não queriam comer.

[...] Eu dava comida pra eles acho que até uns seis anos de idade, eu dava na boca, eu pegava e socava na boca deles a comida, eu queria ver que eles tavam alimentados (risos). Queriam ver que eles tavam alimentados, aí pra mim tava sossegado. [...] Aí eu dava na boca comida pra eles, dava banho neles, acho que até uns sete anos eu dava banho neles, dava banho, dava comida, tudo na boca. Aí demorou pra mim largar deles (risos). Eu acho que isso atrapalha também, né, porque costuma colocar a criança pra comer com uns dois, três anos, eles já começam a pegar a colherinha e ir comendo sozinho, assim, e eu não, eu tinha que socar na boca deles. (Entrevista com Rebeca)

A alimentação, portanto, parece ter sido fonte de conflitos desde a infância de Gabriela. O que era "socado na boca” com agressividade pela mãe passou a ser fonte de angústia e evitado a todo custo. Pode-se pensar no papel simbólico do alimento: ao negá-lo, 
Gabriela parece negar também a agressividade e intrusividade da mãe. O alimento não parece ter adquirido a função de nutrir, mas sim de invadir e devastar.

Ronaldo relatou que costumava atribuir culpa à Rebeca pelo TA da filha, pois a esposa "judiava” muito de Gabriela durante a infância. Gabriela foi a filha "mais maltratada, a que mais apanhou”. Ronaldo pensava, portanto, que a forma agressiva com que a esposa tratava filha e insistia para que ela comesse pudessem estar relacionadas com o início do transtorno.

Que a mãe dela mesmo fazia, quando ela nasceu disse tinha dificuldade de engolir as coisas. Então, disse que ela dava trabalho, então nesse momento que dava trabalho ela dava tapa na menina. Descontava a raiva na menina. Então... Eu acredito, pra ter dificuldade de engolir, de se alimentar de pequena, então a doença já começou por aí mesmo. Pode ser, eu acho. (Entrevista com Ronaldo)

Porém, em momento posterior da entrevista, Ronaldo se implicou na questão do cuidado com a filha, não mais atribuindo culpa apenas à esposa. Relatou que, apesar de se considerar um bom pai, poderia ter se unido mais à esposa e oferecido mais carinho aos filhos.

A princípio a gente, a gente se sente culpado. Você é, que nem, ela [Rebeca] foi uma boa mãe, eu também tenho me sentido que fui um bom pai, então acho que faltou os dois junto. Faltou mais carinho, faltou amor, faltou mais unidade, atenção. Uma vida mais natural de família mesmo, que não teve. A gente se sentia culpado nesse sentido, né? Eu me sentia assim. Também sou culpado, não ajudei, e tudo, mas... Então eu, no meu pensamento eu me sentia que, faltou tudo. Da mãe e do pai. E quando a gente foi acordar já era tarde. (Entrevista com Ronaldo)

\section{As relações familiares}

Tendo em mente a ideia de que “sumir” resolveria seus problemas, Gabriela fugiu de casa: pediu dinheiro para a avó, foi até a rodoviária e pegou um ônibus qualquer para alguma cidade próxima. Esse episódio ocorreu aproximadamente dois meses antes da entrevista. A participante acreditava que “dava muito trabalho para os pais”, e queria “ir morar bem, bem longe”. A pesquisadora, enquanto profissional do serviço onde Gabriela fazia tratamento, 
acompanhou o sofrimento dos pais durante os dias em que ela esteve desaparecida: os pais colocaram cartazes com a foto da filha na rodoviária da cidade onde moravam e acionaram toda a rede de apoio que tinham para ajudá-los na busca. Por fim, Gabriela foi encontrada por uma senhora em uma cidade próxima. Após tê-la acolhido, a senhora reconheceu Gabriela nas fotos dos cartazes e entrou em contato com a família, que foi buscá-la.

Gabriela acreditava que os pais “ficariam melhor sem ela”. Quando requisitada a falar mais sobre isso, permaneceu em silêncio. A pesquisadora perguntou, então, como eram as relações dentro da família, e Gabriela as definiu como “normais”. Quando a pesquisadora tentou destrinchar o significado do que era "normal” para a participante, esta última se irritou e afirmou: “Eu já disse que é normal”. A boca de Gabriela tremia e os olhos se enchiam de lágrimas. Nota-se que as relações familiares configuram um núcleo de angústia difícil de ser nomeada, e que gera bastante resistência e agressividade por parte da participante.

Dos poucos e vagos detalhes que Gabriela forneceu sobre sua família, evidenciou-se que, para ela, são todos muito fechados, não conversam entre si, “é cada um na sua”. A participante contou que quando a mãe pede ajuda para arrumar a casa, geralmente as duas entram em conflito, pois Gabriela “é lerda” e a mãe quer que ela faça as tarefas rapidamente, então toma a frente da filha e faz as tarefas sozinha. Nesse momento, Gabriela sente-se "uma porcaria”.

Ah... Desperta em mim que eu sou uma porcaria. Que eu não presto nem pra ajudar em casa [...] Na verdade eu sou uma desgraça que deveria ter se matado, né, ao invés de fugir. Pelo menos aí, aí acabou, né? Porque ninguém vai atrás, aí já era. (Entrevista com Gabriela)

O sentimento de "ser uma desgraça" surgiu quando, aos 14 anos de idade, começou a ter desmaios na escola, que Gabriela relatou não estarem relacionados à alimentação e sim à ansiedade. Considerava-se bastante ansiosa, tendo inclusive desistido de iniciar curso 
universitário devido ao medo de ser tomada pela ansiedade e desmaiar na sala de aula. Sentiase muito envergonhada com esses desmaios.

O pai era o único acompanhante de Gabriela no tratamento. Estava sempre presente nos grupos de apoio aos familiares, escutava com bastante atenção ao que era discutido e contribuía com experiências pessoais. Rebeca, por outro lado, comparecia poucas vezes ao tratamento e, quando comparecia, não ia ao grupo. As poucas vezes que foi, permaneceu quieta e com expressão de insatisfação e incômodo. Gabriela não referiu sentir-se bem ou mal a respeito da assiduidade do pai, referiu apenas o desejo de abandonar o tratamento.

Pra mim é difícil, né? Eu falei pra, essa semana, eu falei pra ele e pra minha mãe, né, que eu não ia vim, que eu queria abandonar, né? Aí ele falou que não pode, porque o Estado que vai cuidar de mim, que não sei o que, não sei o que lá. Mas por mim eu abandonaria. (Entrevista com Gabriela)

Rebeca contou que desde quando Gabriela era criança, perdia a paciência com ela e “dava uns tapas” para fazê-la comer. Em um momento da entrevista, quando estava falando sobre ter se tornado mãe muito cedo, Rebeca comete um importante ato falho:

Aí ela comia, mas eu nunca fui mãe muito cedo, né, eu fui mãe muito cedo, eu não tinha muita paciência com nada, né? (Entrevista com Rebeca)

Nota-se no discurso de Rebeca sentimentos de não pertencimento ao papel de mãe. Contou também que teve o primeiro filho com 16 anos de idade, e "não tinha preparo, não sabia de nada, como cuidar de uma criança”. O “despreparo" daquela época parece assombrar Rebeca até os dias atuais, pois, durante a entrevista, ela se questionava se os cuidados que ofereceu para Gabriela não haviam sido adequados e poderiam estar relacionados com a ocorrência do TA.

Ao abordar questões familiares, a pesquisadora sentiu que não ficava claro como a mãe se sentia em relação à filha. 
Rebeca era uma mulher jovem e simples, que parecia um pouco envergonhada na situação da entrevista. No grupo de familiares eu sentia um ar de agressividade $e$ raiva por estar faltando do trabalho e tendo que participar das atividades do GRATA. $\mathrm{Na}$ entrevista, porém, foi possível perceber um lado mais vulnerável de Rebeca: percebi que ela sofria por não entender o que acontecia com a filha, se questionava se havia errado em alguma coisa e não sabia como agir. No entanto, algo que não ficou claro durante a entrevista foi como ela se sentia em relação à filha. Pude perceber que falar de amor e sentimentos de carinho era difícil, ela falava com um pouco de vergonha e apreensão. Fiquei pensando em como o afeto é transmitido dentro da família, e quais as repercussões disso no psiquismo de Gabriela. (Diário de campo, entrevista com Rebeca)

Para Badinter (1985), há exceções à regra do amor materno incondicional: como todo sentimento humano, é incerto e experienciado de formas diversas por cada mulher. O amor materno pode se manifestar ou não e, quando se manifesta, pode emergir de diversas formas e intensidades. Portanto, as mulheres tornam-se mães a partir do desejo de ter um filho e da possibilidade de amá-lo, e não apenas da concepção da criança. De acordo com o relato de Rebeca na entrevista, a concepção do primeiro filho aconteceu em um momento em que ela estava começando a vivenciar a própria sexualidade e conhecer o próprio corpo, entrar em contato com a própria feminilidade. Em termos conscientes, a gravidez acidental dos três filhos não parece ter contado com o desejo, e sim com uma série de preocupações de ordem concreta e financeira.

Em contrapartida, Rebeca engravidou acidentalmente três vezes. Ainda que haja um possível desconhecimento ou dificuldade de acesso a métodos contraceptivos, considera-se importante relativizar a ideia de “acidente” trazida pelos pais em suas respectivas entrevistas. Em termos inconscientes, a repetição do “acidente” três vezes leva à hipótese de que havia um desejo do casal de se tornarem pais, possivelmente em uma tentativa de resolver - na relação com os próprios filhos - pendências na relação com seus próprios pais. Segundo Ribeiro (2011), a maternidade tem a função de trazer mudanças nas identificações da mulher com a figura materna, ou seja, de reeditar e “consertar” a relação com a mãe na relação com os filhos - especialmente com a filha mulher, devido à identificação. 
Os sentimentos de Rebeca em relação à filha desde a gravidez até os dias atuais podem ser cruciais na percepção que a própria filha tem de si mesma. Considerando-se que o lugar reservado ao bebê no psiquismo dos pais antes mesmo do nascimento exerce influência direta no desenvolvimento posterior da criança (Matsumoto, 2009), pode-se pensar que a dificuldade de Rebeca para se apropriar do papel de mãe esteja intimamente relacionada - ainda que não seja o único fator determinante - aos sentimentos que Gabriela descreve a respeito de "ser uma desgraça que não devia ter nascido”.

Rebeca e Ronaldo estavam casados havia 20 anos na época da entrevista. Se casaram após Rebeca ter engravidado acidentalmente, aos 16 anos de idade. Segundo o relato de Rebeca, na época da entrevista o relacionamento estava tendo altos e baixos, e ela havia recentemente passado por uma fase de quase desistir, “chutar o balde”, pois sentia que era a única que "corrigia” os filhos e sentia-se sobrecarregada por ter que trabalhar fora e cuidar da casa. Sentia-se a única a desempenhar as funções da casa e, quando estava no trabalho, recebia ligações frequentes da escola de Gabriela relatando desmaios e pedindo para buscá-la. Decidiu então parar de trabalhar fora, deixando as contas da casa sob os cuidados do marido e do filho mais velho. Quando faltava dinheiro, os familiares a culpavam por ter parado de trabalhar. Após um longo desabafo de Rebeca durante a entrevista, evidenciou-se que os conflitos familiares manifestavam-se por meio da questão financeira, que tamponavam conflitos de ordem afetiva.

Evidencia-se que ser mãe - ou ser mulher -, para Rebeca, envolve sobrecarga: trabalhar fora de casa para ajudar a pagar as contas, cuidar dos filhos, limpar a casa, cozinhar e, principalmente, ser cobrada pelos filhos de "não estar fazendo nada”.

Ronaldo considerava que a forma agressiva com que os filhos tratavam a mãe era consequência da forma agressiva com que ela própria os tratou quando eram crianças. O pai contou que a esposa era "bem impaciente e nervosa", batia nos filhos com "tapas na cara”. Já 
naquela época, Ronaldo imaginava que, quando os filhos crescessem, "bateriam de frente com ela”. Quando questionado a respeito de como ele reagia quando via a esposa batendo nos filhos, o pai relatou que tentava conversar, mas a esposa respondia dizendo que "foi criada assim, Deus a fez assim” e nada mudava. Ronaldo representava, portanto, uma figura paterna enfraquecida, que não protegia os filhos da agressividade materna.

A relação de Gabriela e Rebeca, sob a ótica desta última, era de duas irmãs: “A gente conversa, sai junto, se precisar ir em algum lugar com ela, eu vou junto...”. Para a mãe, uma “relação de irmãs” significava ausência de expressão de afeto.

Ah, eu falo assim que não tem, que nem... Tem mãe e filha, assim, que tá sempre... Apesar que tem irmão e irmã também, né, que abraça, beija e tudo... mas nós não tem esse costume. Assim, sei lá, eu acho que nós foi criado assim desde pequeno desse jeito, né? Aí começou... Que nem, eu sei que eu sou mãe dela, ela sabe que é minha filha, só que nós não demonstra, assim, carinho... Sabe? (Entrevista com Rebeca)

No entanto, “relação de irmãs” também remete a uma linearidade da relação, ou seja, não há papéis e fronteiras definidas na família: não se sabe quem é mãe e quem é filha. Não há o exercício da maternidade, com as inerentes ofertas de amor, cuidado e imposição de limites. Acredita-se que a relação entre Rebeca e Gabriela se configurava como “de irmãs”, dentre vários fatores, devido às dificuldades da primeira de se perceber como mãe e, consequentemente, exercer essa função.

As dificuldades tanto de Rebeca em se assumir como mãe quanto dos filhos de assumi-la como mãe ficam claras também no fato de o termo "mãe” não ser utilizado pelos filhos de ambas as gerações.

[...] Que nem, a Gabriela, os meus meninos, eles pegou o costume que nem nós, meus irmãos, de chamar minha mãe pelo nome, né, nós não chama ela de mãe, chama ela pelo nome. Que nem, se eu vou lá na casa dela: “Como é que você tá?”, nós chama ela de C., né? Aí em casa também, os meninos não me chama de mãe, eles chamam de "você", ou se estiver conversando com alguém: "ai, minha mãe falou isso, isso, isso...", eles não chegam em mim e fala: “ô mãe, eu fiz isso, isso, isso"... Eles não 
têm costume de... Acho que é o costume lá da época da minha mãe, que nós acabou trazendo pra gente. (Entrevista com Rebeca)

Próximo do fim da entrevista, Rebeca trouxe histórias de muito sofrimento sobre sua própria família. Além do abuso sexual da irmã mais nova (que será apresentado posteriormente), contou do pai etilista que batia na esposa grávida.

Tinha o pai, a mãe, os irmãos... Ainda pra ajudar, ainda, acho que a minha irmã que ficou doente de repente, né, outra que quase morreu, a caçula... Aí ela ficou doente um tempo, porque meu pai era assim... Era um homem que tomava pinga e ficava louco, ficava louquinho... Quebrava tudo dentro de casa, arrebentava tudo, batia na minha mãe, escorraçava nós, aí nós saía pra rua... Se nós tava morando na fazenda, aí nós tinha que sair da fazenda a qualquer hora que ele aparecia, e saía andando no meio dos matos, chegava em C. [cidade] a pé... Pegava carona, a minha mãe... Aí com esse tempo a minha mãe tava grávida da S., aí batia muito nela, dava paulada nas costas dela, e ela tava barriguda, tava gorda já pra ter ela... Aí eu não sei se devido a esses espancamento que ele dava nela, ela nasceu e diz que tinha um problema. (Entrevista com Rebeca)

Nota-se, portanto, que Rebeca não conheceu afeto e cuidados dentro de sua família. A maternidade era associada a distanciamento, e a paternidade à violência. Como passar para os filhos algo que ela mesma não teve? Para De Felice (2006), a internalização de uma "mãe boa” é crucial na vivência da função materna. Quando há sentimentos de hostilidade em relação à mãe internalizada, a maternidade será vivenciada de maneira angustiante e permeada por sentimentos de culpa. Vale ressaltar que o significante “culpa” foi mencionado inúmeras vezes tanto por Rebeca quanto por Ronaldo.

Aí meu pai, como ele tinha costume de bater na minha mãe quando ele bebia, aí minha mãe pegava ela, socava nos meus braços... tacava ela nos meus braços e nós ia pra cidade a pé, podia ser meia noite, uma hora da manhã, nós ia embora pra cidade... ou então dormia lá no meio da cana... ficava todo mundo em pé lá no meio do canavial, da cana, até [...] Ele chegava em casa, ele arrebentava tudo que ele via na frente e a função dele era pegar só minha mãe, só pegar ela, bater nela, alguma coisa ele tinha que fazer com ela... Machucar, arrancar sangue dela. Aí nós ficava tudo assustado, né, nós era pequeno, nós pulava a janela... Uma vez ele subiu uma parede, assim, que nem uma aranha, que nem sei como que ele conseguiu subir aquela parede, subiu pra pular dentro do outro quarto, tava eu, minha mãe e minhas irmãs... E a S. já não andava, não falava... Aí a gente pulou a janela, né, aí quando 
ele tava subindo pra pegar minha mãe lá dentro do quarto, aí eu e meus irmãos pulou a janela, passou a S., jogou ela lá embaixo, meu irmão pegou ela e nós correu tudo pro meio do canavial e minha mãe conseguiu escapar... Enquanto ele tava lá em cima, ela abriu a porta do quarto e correu pra fora, porque... Ele pegava punhal, faca, foice, tudo... Ele queria só tirar sangue dela e a gente viveu assim, né? Nessa correria desde pequenininho... Aí a gente dormia no meio da cana, ou então vinha a pé pra cidade, pra se livrar dele... (Entrevista com Rebeca)

Ronaldo também não tinha o hábito de chamar o pai de "pai”, “tinha vergonha”. Foi criado pela avó, pois os pais não tinham dinheiro suficiente para cuidar de todos os seis filhos. Acabou por se distanciar emocionalmente dos pais e se aproximar cada vez mais da avó, que não quis que ele se casasse quando Rebeca engravidou. Não teve um modelo paterno, e contou que preferia ser como um "irmão" para os filhos, em vez de pai. Não sentia que tinha “estrutura emocional” para ser chamado de pai.

Tanto é que foi tão difícil que, assim, eu ajudava a ir no postinho e tudo, mas quando eles começou a ir no parque, quando eles começou na escola, quando eu ia buscar eles, os outro falava assim "Ah seu irmão veio buscar vocês?" não sei o que... E eu não gostava, achava... Eu gostava mais que eles me entendesse como irmão que de pai. Eu tinha isso comigo lá, que era mais bonito me entender como irmão do que pai. (Entrevista com Ronaldo)

Tanto o pai quanto a mãe de Gabriela se colocavam na posição de “irmãos” dos filhos, demonstrando dificuldades para se apropriar e exercer o papel de pais. No entanto, a partir do adoecimento da filha, Ronaldo parece ter se deparado com a necessidade de assumir esse papel: levava Gabriela ao tratamento no GRATA mesmo quando esta não tinha vontade de ir, cuidava para que ela tomasse os medicamentos e participava do grupo de apoio aos familiares. Contou que, quando a filha fugiu de casa, depois pediu desculpas a ele, o que foi compreendido por ele como um reconhecimento da parte da filha de todos os esforços que ele vinha realizando para cuidar dela. Portanto, o TA desempenhava uma importante função na família: impelia os pais a se tornarem de fato pais. 
Eu já penso assim agora, já que de pequeno eu não fui um bom pai, não demonstrei ser um pai, acho que agora é o momento. Se não for agora, também... Agora tem que ver isso, né? Mas quando ela fugiu ela pediu desculpa pra mim. (Entrevista com Ronaldo)

\section{O despertar da feminilidade}

A menarca de Gabriela aconteceu aos 12 anos. A participante referiu, dando risadas, ter sido um acontecimento "engraçado", pois "não sabia o que era e pensava que era hemorroida".

Ah porque na verdade eu nem sabia que tinha, que existia isso, minha mãe nunca me falou nada, aí eu aprendi isso na escola, né, aí, só que quando veio a primeira vez eu não tinha aprendido nada sobre isso, aí eu achei que eu tava com hemorroida (risos). Nada a ver uma coisa com a outra, né? (Entrevista com Gabriela)

Depois de ter aprendido na escola o que era menstruação, a participante relatou: “Aí eu pensei: 'Não acredito que tem mais isso.' (risos) Eu não sabia, né, pra mim não tinha nada disso...”. Quando questionada a respeito “do que mais” havia, Gabriela não soube responder, disse que não se lembrava. Entretanto, o trecho aqui citado parece fazer referência subjetiva a dificuldades que a jovem vinha vivenciando com a própria feminilidade, tanto dentro da família como em outros âmbitos da vida.

Gabriela não pôde descrever sensações e impressões a respeito da menarca, e nem de como a notícia foi recebida pela sua mãe: “Ah, ela só me ensinou como que colocava o negócio lá.”. Achava "estranho” e “diferente” a forma como o corpo foi mudando com a entrada na puberdade, e relatou que gostava mais de quando era criança, pois era mais feliz. “Aí depois que eu entrei na adolescência virou um inferno.”. Ao tentar explicar esse “inferno”, Gabriela se lembrou de um episódio ocorrido no início da puberdade:

Ah... Não sei, só sei que... Quando eu tinha treze anos, é... Aí eu já estava na adolescência. Sei lá, me deu um... Como eu te falei, eu estudava muito, né? Aí me deu um negócio muito ruim na escola, assim, eu peguei e saí gritando, assim, eu nem vi o que eu tava fazendo. Só sei que de repente eu caí no chão com tudo, assim, aí eu não 
lembrava de mais nada. Aí meu nariz começou a sair sangue, assim, e eu gritando, gritando, eu perdi as forças do corpo, mas eu não sei o que que é isso. Aí foi depois disso que tudo começou. (Entrevista com Gabriela)

Frente a esse acontecimento, Gabriela relatou que lhe foi atribuído diagnóstico de esquizofrenia. Sentiu muita vergonha dos colegas e dos pais, que foram chamados à escola. Após confidenciar esse acontecimento traumático para a pesquisadora, a participante interrompeu a entrevista de forma brusca, respondendo à todas as perguntas e colocações de forma monossilábica. Nota-se, portanto, que se tratava de um conteúdo difícil de ser tolerado pela psique de Gabriela, uma vez que as frases monossilábicas indicam clara resistência para entrar em contato com tal conteúdo.

Vale ressaltar que, segundo o discurso de Gabriela, os desmaios foram iniciados na puberdade, que marca o início da vida adulta e do advento dos atributos femininos. Segundo Miranda (2007), as modificações incontroláveis no corpo típicas da adolescência podem fazer com que a menina reviva conflitos primordiais, além de colocarem em pauta o luto pela perda da infância e da relação fusional com a mãe. Trata-se, portanto, de uma fase conflituosa para a menina, que precisa que a mãe tenha disponibilidade mental para tolerar as mudanças o devir da feminilidade da filha, e a consequente separação (McDougall, 1991/1997).

Para Rebeca, a primeira menstruação da filha foi "normal”. Relatou que tratava desse assunto de maneira diferente de sua própria mãe, pois conversava com Gabriela sobre atrasos e cólicas. Quando teve a sua própria menarca, Rebeca não contou para sua mãe, pois tinha muita vergonha. Rebeca acreditava que sua mãe apenas notou que a filha estava se tornando mulher quando esta engravidou do primeiro filho, pois até aquele momento mãe e filha nunca haviam conversado a respeito de menstruação, gravidez, sexualidade, entre outros. O nãoreconhecimento da mãe de Rebeca do amadurecimento feminino da filha pode estar relacionado às dificuldades desta última em se perceber mãe, uma vez que, para alcançar a feminilidade madura - e, consequentemente, se tornar de fato mãe -, a menina precisa ter 
recebido da mãe uma importância libidinal ao seu corpo feminino. A ligação homoerótica com a mãe é decisiva na constituição da feminilidade (McDougall, 1991).

Ronaldo soube da menarca da filha pela esposa, pois era o responsável por fazer as compras da casa e teria que comprar mais absorventes. Relatou que, quando recebeu a notícia, foi “normal”, sem conseguir explicar melhor o que aquela notícia havia despertado. Sob a ótica de Ronaldo, Gabriela nunca havia se interessado por namoro, pois ainda não apresentava um amadurecimento emocional condizente com a idade cronológica. Tal observação do pai está de acordo com a literatura científica a respeito de mulheres com TAs, que apresentam fixações em fases pré-edípicas do desenvolvimento psicossexual, em função da dificuldade de abandono da relação fusional com a mãe (Halberstad-Freud, 2001; Miranda, 2007).

Eu acho que sim, preocupa sim, porque não é normal. Pela idade dela, porque aí fica muito ingênua, né? Muito... Muito perdida, eu acredito assim, vai ficar uma moça perdida, né? Vou dizer, ela tá desenvolvendo agora, praticamente, então no estágio que ela tá, é que nem dizer, como tá saindo do estágio de criança. (Entrevista com Ronaldo)

A concepção do pai acerca da feminilidade era de sentimentalismo e fragilidade, como se mulheres fossem mais propensas a adoecerem, e gerassem mais dificuldades ao cuidado parental. Considerando-se a transmissão inconsciente de conteúdos psíquicos (Lisboa \& Fères-Carneiro, 2015), acredita-se que a dificuldade que o pai relatou de criar uma filha mulher possa estar relacionada, dentre outros fatores, ao sentimento de Gabriela de ser "uma desgraça”.

Assim, opinião minha, eu acho, pra mim a mulher é mais difícil de criar. Não sei é por causa dessas bobeiras... Eu achei mais fácil criar os outros. [...] Sei lá, não sei se é porque é mais sentimental, é mais frágil, sei lá. Pra mim, é, foi mais difícil, não sei [...] Ela já teve estrabismo, também, até que a gente trouxe ela na época aqui pra operar, pra não ficar com defeito, não crescer e ficar com o olho torto... Teve esses processos, também... (Entrevista com Ronaldo) 


\section{Relacionamentos afetivos e vida sexual}

Gabriela relatou que nunca teve relacionamentos afetivos e/ou sexuais, e nunca beijou na boca. Sentia nojo, mas não sabia explicar o motivo. Referiu não ter desejo nem curiosidade a respeito de conteúdos sexuais. A vida social de Gabriela, de maneira geral, era bastante empobrecida: a participante tinha um único amigo, não saía de casa, não participava de eventos da escola e não ia a festas de aniversário ou outras comemorações. Contou que não se sentia bem dentre muitas pessoas, mas não conseguiu explicar que tipo de emoções essas ocasiões lhe geravam.

Outras demonstrações de afeto, ainda que não fossem de ordem sexual, também eram evitadas pela participante. Por exemplo, não se sentia confortável para abraçar ou beijar pessoas próximas. A própria noção de proximidade afetiva era plausível de ser colocada em pauta, uma vez que Gabriela demonstrava sentimentos de desamparo e solidão bastante arraigados dentro de si.

Em um dado momento da entrevista, Gabriela disse que nunca tinha beijado na boca, tinha nojo de beijo e sexo, e não tinha o hábito de abraçar pessoas queridas. Disse também que evitava até mesmo filmes que tivessem cenas ou conteúdos eróticos. Ficaram passando cenas na minha cabeça de como seriam os dias daquela jovem, sem ter com quem conversar, sem assistir filmes, sem fantasiar, criar, desejar... Senti que poderia ser desesperador. (Diário de campo, entrevista com Gabriela)

Apesar da mãe de Gabriela às vezes dizer que ela "precisa arrumar um namorado para sair mais de casa”, a participante relatou que questões sobre namoro e sexualidade nunca foram conversadas em família. Acredita que os pais têm vergonha de falar sobre esses assuntos.

Em contrapartida, Rebeca relatou que conversa com os filhos a respeito de namoro e sexualidade. Quando questionada a respeito da vida sexual de Gabriela, a mãe contou que, no início dos sintomas de TA e dos desmaios da filha, imaginou que ela poderia ter sido sexualmente abusada na escola, ou que ela poderia ser homossexual. 
Ah, porque é tanto pensamento na cabeça, que a parte desse problemas, assim, que ela começou de repente, assim... Esses problemas aí, né, que parecia que ela escondia algo de nós... aí eu até pensei, né? [Que a filha poderia ter sido abusada] Ainda até pensei que, tipo assim, se ela fosse... como é que fala? Quando mulher gosta de mulher? [...] A gente chegou nela, conversou tudo... Explicou certas coisas, né, minha irmã foi abusada quando ela era pequenininha, cinco anos... Aí nós explicou pra ela: “Aconteceu isso, isso e isso na família”, se ela não... Porque nós achava que era, né? Alguém ter abusado dela, que ela nunca namorou ninguém... Relação, assim, ela nunca teve... Até a gente pensou, né, às vezes ela guarda alguma coisa, alguém abusou dela, e ela põe essas coisas na cabeça e ficou desse jeito aí. Mas graças a Deus não é. (Entrevista com Rebeca)

Segundo o relato de Rebeca, o abuso sexual da irmã permaneceu presente na vida da família como uma “coisa ruim” até os dias atuais, sendo lembrado também pelas pessoas da cidade onde moravam. Rebeca culpou-se por não ter estado presente para cuidar da irmã não conseguiu desempenhar o papel de mãe? Contou que sua tia também foi abusada quando criança, mas não sabia detalhes do acontecido.

Além da irmã e da tia de Rebeca, Ronaldo também sofreu abuso sexual, aos 13 anos de idade. O participante contou que estava jogando futebol com alguns amigos quando um vizinho mais velho, de aproximadamente 30 anos, pediu que ele o acompanhasse para buscar algo em sua casa. Estavam andando sozinhos por um "brejo" quando o vizinho tirou um punhal do bolso e ameaçou matá-lo se Ronaldo não o obedecesse. O pensamento mais recorrente de Ronaldo naquele momento, segundo seu relato durante a entrevista, era de que a avó não sobreviveria sem ele, e por isso obedeceu ao homem. Não contou do abuso a ninguém, até recentemente. Tinha vergonha e “medo do vexame”, e também medo de que seus pais acusariam a avó de não ter cuidado bem do neto.

Ronaldo confidenciou que, depois do abuso, tinha muito medo de adoecer de Aids e passou a ter "pensamentos maléficos” sobre matar o homem que tinha sido responsável pelo abuso. Considerava que ter começado a frequentar a igreja evangélica foi o que ajudou a atenuar os “pensamentos maléficos”. A primeira pessoa para quem Ronaldo contou do abuso foi a esposa, 20 anos depois do acontecido. Em seguida contou aos filhos, especialmente para 
Gabriela, com o objetivo de demonstrar que acontecimentos ruins podem ser superados por meio da fé em Deus.

Sobre o relacionamento do casal parental, Gabriela definiu-o como “esquisito”, sendo os filhos o único aspecto que mantinha os pais unidos.

Ah sei lá, tipo, quando um faz aniversário, vamos supor, se meu pai faz aniversário, minha mãe não chega, não dá parabéns, não faz nada, sabe? Se é com a minha mãe também é a mesma coisa. Sei lá, eles são, eles são... Afastados, um pouco, assim. Eu acho. (Entrevista com Gabriela)

Ronaldo e Rebeca foram os primeiros relacionamentos sexuais um do outro. Namoravam há três meses quando engravidaram acidentalmente do primeiro filho. Rebeca contou que a vida sexual do casal sempre teve entraves, aos quais ela atribuía motivos externos, tais como ter sempre morado em casas pequenas, de um ou dois cômodos. Ambos descreveram a relação entre si como “de irmãos”.

Ah, tem... de vez em quando, assim, tem dificuldade porque a casa que a gente mora... que nem, no começo nós morava nessa casa da mãe dele, assim depois desse primeiro cômodo que nós morou, aí depois foi pra dois cômodos quando nós fomos lá na casa da vó dele... Lá raramente nós tinha alguma coisa, assim sabe, era raro, ixi, só teve mesmo quando eles era pequenininho, não sabia de nada, era tudo pequenininho... Aí depois que eles cresceu, aí virou uma rotina, assim, como se fosse dois irmão, sabe, dentro de casa. Até hoje, assim... agora que nós tamo morando nessa casa que é dois quartos, que é um pouquinho maior, até hoje é como se fosse dois irmão... não tem aquela... como que fala? Não tem muito diálogo... (Entrevista com Rebeca)

Assim, aqueles problema, acontece, né? Assim, a frequência, às vezes, né? Que fica que nem irmão assim, às vezes. Os meu, até os menino fala assim "Vocês parece irmão, você num se beija, num se abraça, assim.” Meus menino às vezes vão nas casa dos colega deles e é bem assim, o casal se abraçando, se beijando na frente dos filho assim. A gente não teve isso, né? Não tive... Até quando namorou, assim, dentro de casa a gente não era assim, sabe? Não é que é assim, é que foi assim, sempre, desde o princípio... (Entrevista com Ronaldo)

Segundo o relato de Rebeca, o filho mais novo dizia que os pais eram um "casal quadrado", que não se beijava e nem se abraçava. Nota-se, novamente, a dificuldade de expressão de afeto e a confusão de papéis na família Ribeiro: pais e filhos são como “irmãos”, 
filhos não chamam a mãe de “mãe”, e o casal parental se define como “irmãos”. As fronteiras dos relacionamentos parecem ter sido obliteradas, e os papéis foram confundidos. A partir desses dados, hipotetiza-se que os sintomas alimentares e os desmaios de Gabriela configurem expressões da necessidade de que os pais se posicionem enquanto pais de fato, cuidando e impondo limites.

Para o marido, dos 20 anos em que o casal estava junto, 16 foram "polêmicos": não tinham lugar para morar, passavam por muitas dificuldades financeiras e tinham um relacionamento conturbado, com muitas “faíscas”. Várias vezes Ronaldo pensou em se separar, mas acreditava que essa solução para os conflitos conjugais seria "pior para os filhos".

Pra mim foi mais difícil aceitar, assim, o sofrimento das crianças, que apanhavam muito, e eu não conseguia corrigir isso. Eu podia largar, mas não, largar era pior, eu casei, e as crianças iam pra onde? Então é difícil viver junto, assim... E as crianças sem pai? Eu pensava por esse lado. (Entrevista com Ronaldo)

No entanto, quando questionado a respeito de possíveis arrependimentos em relação ao casamento, Ronaldo relatou que não tinha nenhum. Para ele, a vivência em família era permeada por sentimentos de culpa da parte de ambos os pais - no que tange ao cuidado dos filhos -, mas acreditava que “viviam bem”. Nota-se ambivalência no discurso de Ronaldo, que hora afirmava o desejo que já havia tido de separar-se da esposa, e hora afirmava que “viviam bem”. Acredita-se que esta ambivalência configure mecanismo de defesa contra a angústia de encarar as insatisfações no casamento e se sentir compelido a considerar a possibilidade de separar-se da esposa. Essa possibilidade, além de ser angustiante por si só, também parece gerar fantasias de piora dos sintomas da filha, o que intensificaria os sentimentos de culpa já vivenciados por Ronaldo. 


\subsubsection{Família Freitas}

Manoela, a filha: “É estranho conversar com pai, principalmente por você ser mulher"

Carol, a mãe: “Parece que a gente era muito parecida, né?”

Rodrigo, o pai: “Parece que num dá valor na mulherada, né?”

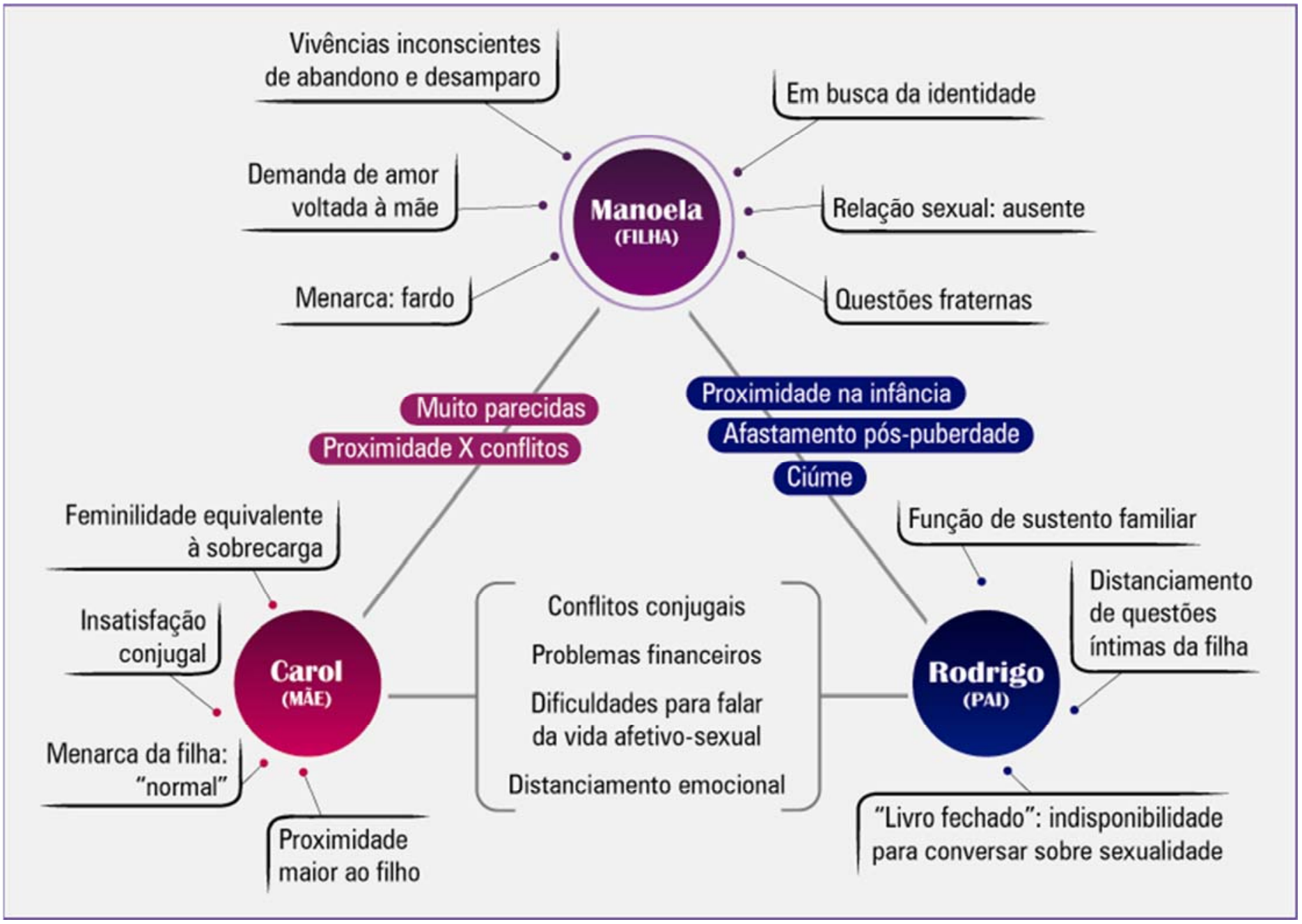

Figura 7. Mapa de associação de ideias da família Freitas. 
Manoela iniciou o tratamento após duas internações, uma mais curta (15 dias) no serviço de Nutrologia e Metabólica, e outra relativamente longa (35 dias) na Psiquiatria. Segundo seu relato na entrevista, decidiu emagrecer porque "se achava gorda” e achava que “não estava legal”. Após a segunda internação, Manoela começou o seguimento no GRATA. Pesava 36,6 kg, tinha 1,61 m de altura e IMC = 14,1 kg/m².

A entrevista foi realizada um ano após o início do tratamento de Manoela. A participante havia recuperado $13 \mathrm{~kg}$, e apresentava $\mathrm{IMC}=18,9 \mathrm{~kg} / \mathrm{m}^{2}$. Tinha 14 anos de idade, era a filha mais velha (tinha um irmão de sete anos) e a família tinha uma renda mensal de aproximadamente 5.000,00 reais. Entretanto, a pontuação no CCEB/2015 indicou que a família se encaixa no estrato socioeconômico B1, que engloba rendas de aproximadamente oito mil reais.

\section{O transtorno alimentar}

Na época da entrevista, a equipe do GRATA estava avaliando a possibilidade de dar alta do serviço à Manoela, uma vez que esta encontrava-se eutrófica e com pouca insatisfação corporal. A participante contou que, depois das internações e de alguns meses de tratamento, começou a sentir falta de encontrar os amigos, ir a festas de aniversário e comer normalmente. Por esse motivo, aproximadamente 10 meses antes da entrevista, foi voltando a se alimentar e a ter vida social. Além disso, sentia-se “diferente" dos amigos, "queria ser igual a todo mundo” e tinha medo de ser internada novamente.

Mas tipo assim, eu me via diferente, aí eu queria mudar pra ser igual todo mundo e pra fazer tudo que todo mundo fazia. Até porque eu ia fazer, tipo, eu ia em alguma coisa da escola, eu... Educação física, alguma coisa, eu não conseguia fazer. Então eu via todo mundo fazendo, eu queria fazer, só que eu sabia que se eu não comesse, não melhorasse, se eu não quisesse melhorar, eu não ia fazer. E eu ainda tinha, naquela época eu ainda tinha medo de voltar pra cá, então mais uma vez o medo de voltar pra cá também ajudou. (Entrevista com Manoela) 
A primeira internação de Manoela foi no ambulatório de Nutrologia do Hospital das Clínicas e durou 15 dias. Porém, a segunda internação foi mais difícil tanto para a mãe quanto para a filha: foi na Psiquiatria e durou 35 dias. Carol relatou que Manoela parecia a única pessoa “normal” de lá, apesar de atualmente saber TAs são também transtornos psiquiátricos. Na segunda vez em que foi internada, Carol não pôde permanecer no hospital, em função do trabalho. No entanto, o discurso de Carol sobre a angústia de ver a filha internada e o medo dela vir a falecer pareciam também estar relacionados com a dificuldade de acompanhá-la na internação.

Não, eu queria deixar a Manoela aqui, não queria ir embora, mas eu não aguentava mais ver aquilo, eu não tinha esperança da Manoela salvar e eu não queria ver a Manoela morrer junto comigo. Falei: "Gente, vou ver essa menina morrer e eu não vou dar conta de ver isso, hein?”. Aí um dia, muito desesperada, eu procurei ela, falei: "Ai, eu não aguento, eu vou embora, deixa eu ir embora”. (Entrevista com Carol)

No momento da entrevista, Manoela relatou que se sentia bem com o próprio corpo e não tinha mais desejo de emagrecer. Reproduzindo discursos da psicóloga e da mãe, Manoela atribuiu a ocorrência do TA aos ganhos secundários, tais como maior atenção por parte dos familiares. A participante sentia muito ciúme do irmão mais novo, e acreditava que a mãe gostava mais dele do que dela. Com o TA, passou a receber mais atenção da avó e principalmente da mãe.

Sob a ótica de Carol, o TA da filha se iniciou em uma viagem com uma amiga. Manoela estava acostumada a viajar com essa amiga, mas dessa vez ligou para a mãe várias vezes dizendo que queria ir embora. Os pais não podiam busca-la devido à distância e aos compromissos de trabalho, então a filha permaneceu na viagem com a amiga por mais alguns dias. Logo após essa viagem com a amiga, a família Freitas fez uma viagem para a praia, na qual começaram a perceber que Manoela estava comendo menos que o normal - pois desde sempre comeu pouco, segundo o relato de Rodrigo. Depois desses eventos, Carol e Rodrigo 
relataram que a filha começou a reclamar que estava gorda e a diminuir lentamente a alimentação. Foi parando de sair com os amigos, de ouvir música e ver televisão, ficando cada vez mais isolada. Após assistir a um programa de televisão sobre TAs, Carol conversou com a filha e levou-a a vários profissionais, até que foi encaminhada ao GRATA.

No início, Rodrigo relatou que não compreendia que a filha tinha um transtorno, e sentia-se muito entristecido por ver a filha negar comida e "jogar a vida fora". Confidenciou que não sabia o que fazer para ajudá-la, pois dizia para ela comer, e as pessoas à sua volta diziam que ele não podia insistir para que ela comesse: "Se eu não falar para ela comer, vou falar o que? É só o que eu sei falar”.

Mas na verdade, foi muito triste. Porque eu... Tudo que a gente falava e... Cê falava assim "Ôh Manoelinha, come! Porque se ocê num comê cê... Cê tá morrendo! Cê tá... Cê Tá jogando tua vida fora!”, "Ah, eu não consigo!”. A única coisa que ela sabia falar era "eu não consigo". Aquilo me matava, porque... Comê é tão fácil, né... Tão gostoso. (Entrevista com Rodrigo)

Em momento posterior da entrevista, Carol relacionou o início dos sintomas de TA ao início da puberdade de Manoela.

Eu acho que ela assustou mais, porque eu acho que o transtorno dela veio na hora que ela começou ficar... Que ela sentiu que o corpo dela ficou mais... A transformação de menina pra mocinha. (Entrevista com Carol)

Alguns autores (Lane, 2002; Simoni \& Bastos, 2013) consideram a AN como resposta inconsciente à sexuação, ou seja, ao processo de tornar-se mulher: os sintomas manteriam essas jovens em posição infantilizada, com o corpo e os pais da infância, evitando o desenvolvimento corporal, a maturidade sexual e a feminilidade. Assim, as jovens acometidas parecem regredir à fases pré-genitais do desenvolvimento psicossexual, estando, portanto, livres da responsabilidade de tornar-se mulher. 
Ambos os pais relataram que, na época da entrevista, Manoela estava melhor em relação ao TA: não demonstrava insatisfação com o corpo e com o peso, fazia os trabalhos da escola, saía com os amigos e se divertia.

\section{As relações familiares}

A relação entre mãe e filha, sob a ótica da filha, é “muito boa”, pois conta tudo para a mãe, “não tem segredos”. A mãe, por sua vez, conta tudo para o marido, mas este não conversa com Manoela sobre nenhum dos assuntos que a esposa compartilha com ele em relação à filha.

É, aham, ela sempre conta pro meu pai... Mas meu pai não fala nada, ele age como se não tivesse acontecido nada. (Entrevista com Manoela)

Apesar da proximidade entre mãe e filha, a participante contou que, quando era mais nova, brigava muito com a mãe. Para ilustrar as brigas, citou as vezes em que as duas iam comprar roupas, e a mãe “obrigava” Manoela a comprar a roupa que ela - mãe - havia gostado, ainda que a filha tivesse gostado de outra. No entanto, as brigas diminuíram conforme Manoela foi crescendo, e a mãe voltou-se mais ao filho mais novo.

Ai, não sei, no começo ele [irmão] tinha muito ciúmes, hoje em dia eu não me importo mais não. Eu até prefiro. Aí ela larga do meu pé [risos] e fica no pé dele. Porque minha mãe é muito estressada, ela é muito explosiva assim... Então se ela... O dia que ela tá estressada no serviço dela, à noite você nem... Nem conversa, se não ela começa gritar com você, apesar de você não ter feito nada, ela grita com você, ela faz... E assim, aí é bom que ela foca no L. e me esquece um pouco [risos]... E não fica tão estressada assim comigo. (Entrevista com Manoela)

Ao descrever a infância de Manoela, Carol caracterizou-a como uma criança muito apegada aos pais, com dificuldades de aceitar a presença e os cuidados de outras pessoas, ainda que fossem da família. A mãe acreditava que, de alguma forma, o TA da filha se 
articulasse com o fato de Manoela ter sido "uma menina muito difícil” e "diferente das outras crianças”.

\begin{abstract}
A gente fala que não sabe muito o motivo da doença da Manoela, mas um pouco a gente, eu mãe dela a vida inteira sei, talvez seja isso... A Manoela foi uma menina muito difícil, desde pequena [...] A Manoela detestava gente... O mundinho dela era só nós ali. [...] Vamos supor, quando era pequenininha, ela não ia no colo de ninguém, só meu, do pai ou da minha sogra... Nem dos tios, nem do padrinho, nem do vizinho, nem ninguém. [...] Ela não gostava que eu e o pai conversasse com os outros, tinha que ficar só perto dela... Ela não deixava a gente conversar, por exemplo, se ela visse eu conversando com você agora, ela taria assim: "Mãe, vamos embora? Mãe para com isso... Para, para, vamos embora mãe, vamos embora". Então ela achava que o pai e a mãe era só dela [...] (Entrevista com Carol)
\end{abstract}

Manoela parecia viver a fantasia edípica ideal de toda criança: ter os pais só para si, longe da cidade, de outras pessoas e de possíveis “ameaças” à essa relação ideal. Portanto, aceitar o crescimento e o advento de situações que a tirassem daquele meio "protegido" da família - tais como a puberdade e a consequente maturação sexual - parece ter sido fonte de angústia.

Na primeira vez em que Manoela citou o pai durante a entrevista, se emocionou. Contou que o pai era muito "brincalhão", e que certa vez ele fez uma brincadeira com ela durante a internação e ela ficou brava, e desde então ele decidiu que não brincaria mais com ela. Manoela sentia que, além de ter parado de brincar, o pai também havia parado de conversar com ela.

A relação com o pai foi caracterizada por Manoela como distante, uma vez que os dois só se viam de manhã antes da filha ir para a escola, e a noite. Rodrigo trabalhava todos os dias, inclusive aos domingos, e por isso não pôde permanecer no hospital com a filha durante a internação. No entanto, Manoela confidenciou que sentia mais falta da mãe.

Só que eu não tenho, assim, abertura pra conversar com essas coisas com meu pai, sabe? É meio... Ah, não sei, é estranho conversar com pai, principalmente por você ser a filha mais velha, por você ser mulher... Você falar com o pai assim. (Entrevista com Manoela) 
A mãe parecia ter uma visão diferente de Manoela em relação à proximidade entre pai e filha: enquanto Manoela descrevia a relação como distanciada, a mãe considerava que os dois sempre foram muito próximos, e que a relação entre mãe e filha tornou-se mais próxima apenas durante a primeira internação de Manoela, quando as duas passaram muito tempo juntas.

Então, e ela tinha uma proximidade muito grande com o pai dela. Ela e o pai até hoje são assim, eu acordo às vezes de manhã... Eles tão tomando café juntos, porque ele sai pra trabalhar de manhã junto com ela e ela tá indo pra escola... Eles tão brincando, eles tão correndo um atrás do outro pelo corredor, então eles têm uma... Uma afinidade muito grande. Já eu e ela não, a gente era bem diferente, então isso criava um certo atrito entre a gente, sabe? Aí depois da doença a gente ficou muito próxima, porque eu fiquei eu e ela sozinha... Nós ficamos 15 dias sozinhas aqui... Sem interferência de ninguém, sem ter pai, sem ter irmão. (Entrevista com Carol)

Para Rodrigo, sua relação com a filha é muito boa. Contou que desde quando ela era pequena, os dois estavam sempre juntos, pois ela ficava com ele o dia todo enquanto ele trabalhava na roça. Entretanto, Rodrigo relatou que, na época da entrevista, Manoela costumava conversar mais com a mãe, mas não soube explicar o motivo.

Sempre que dá, nós conversa. Hoje num conversa tanto mais assim, porque... Ela... Né. As coisas que... Que conta mais assim, é pra mãe dela... Assim, né, as coisas... Que... (Entrevista com Rodrigo)

Rodrigou também mencionou que sentia muito ciúme da filha, e atribuiu esse sentimento ao modo como os homens lidam com as mulheres atualmente. Referiu-se às músicas sertanejas atuais, mas não conseguiu expressar exatamente o que lhe causava incômodo, trazendo um discurso bastante reticente: “Tudo é... De não sei o que, que pegou, que fez isso, que fez aquilo... Então você fica, às vezes, você fica imaginando coisa, né... Ruim, né... Pro pai é ruim.”

Carol também descreveu Rodrigo como uma pessoa distante, bastante engajada no trabalho e em atividades externas. Apesar de ter consciência que o marido trabalha muito para 
poder oferecer o melhor aos filhos (escola particular, curso de inglês, entre outros), Carol acredita que o marido deveria passar mais tempo com ela e com os filhos. Para ela, “família é família, tem que tá junto”.

A gente andou brigando muito ultimamente, a gente andou distanciando muito um do outro por isso. Ele trabalha todos os dias, inclusive domingo... E ele sai de casa por volta de seis e meia e chega em casa... Tem dia que ele chega mais cedo, que é aos domingos que ele chega sete horas da noite... É oito, nove, e além disso, além dele trabalhar muito, ele ainda arruma muita coisa pra fazer fora de casa. Ele participa de... Ele ajuda em... Lar de idoso, ajuda em conferência que é... O que forma pra ajudar os necessitados, de gente que passa necessidade de alimentos, ele ajuda... Ele ajuda na escola dos meninos, ele faz parte do grupo escolar... Então todos os dias ele tem uma reunião. (Entrevista com Carol)

A relação afetiva do casal parental, segundo o relato de Carol, vem sendo prejudicada há aproximadamente 10 anos, quando Rodrigo adoeceu - precisou fazer um transplante de rim, doado pelo pai - e precisou parar de trabalhar. A família morava em uma casa do pai de Rodrigo, emprestada, que ficava na roça. Carol nunca gostou de morar na roça e tinha planos de morar lá por apenas um ano. No entanto, com o adoecimento do marido, continuaram morando lá por sete anos.

[...] Já culpei ele nisso, e ele sentia isso, porque ele fez a minha vida meio difícil... De morar na roça, eu não gostava, eu fui pra roça pra ficar um ano... Acabei ficando sete anos na roça, porque logo ele ficou doente. Tava com três anos, quatro anos de casamento ele ficou doente. A Manoela tinha dois anos parece... Ele ficou doente, doença dele foi quatro, cinco anos, não sei... Eu tive que morar dentro da casa da mãe dele com mais oito irmãos... E mais uma senhora que morava lá também que é tia dele. Então foi bem tumultuado, já começou tumultuar nosso casamento que era tranquilo [...] (Entrevista com Carol)

A questão financeira vinha permeando o relacionamento do casal desde o adoecimento de Rodrigo: Carol passou a ganhar mais dinheiro que ele, pois fazia cursos e conseguia serviços extras. Considerava que o marido se sentia incomodado por ela ganhar mais dinheiro. Rodrigo relatou uma história recente que envolve a questão financeira, e que estava trazendo vários problemas para o relacionamento dos dois: um amigo havia feito uma dívida, e 
Rodrigo e Carol assinaram como fiadores. Quando o amigo não realizou o pagamento, o casal ficou responsável por arcar com a dívida, que chegava a 94 mil reais. Segundo o relato de Rodrigo, Carol o culpava pelas dificuldades que estavam passando, já que ela não queria ter assinado o documento. Ele, por outro lado, afirmava que a esposa havia assinado por livre e espontânea vontade. Na época da entrevista, o problema ainda não havia sido solucionado, mas Rodrigo estava encontrando meios de ajudar o amigo a conseguir dinheiro para pagar a dívida.

Carol demonstrou profundos sentimentos de carinho e gratidão pelo marido durante a entrevista.

Apesar de ser difícil, do nosso casamento tá difícil, jamais eu arrependo de ter casado com ele... Jamais eu gostaria de ter voltado no tempo e não ter casado com ele ou de separar dele... Porque é uma pessoa que me ensinou muito... Ele é extremamente bondoso, ele tem o coração muito bom, uma pessoa super amável com os outros, com a minha família, com os meus amigos, com os que tão a minha volta, então é... Uma pessoa que aonde ele chega é, é... É assim, uma alegria... Então, ele é muito especial. (Entrevista com Carol)

No entanto, em momento posterior da entrevista, a mãe revelou que "nunca teve aquele amor louco por ele [marido], esses amores que a gente vê as meninas falarem, que a gente vê em novela, que todo mundo fala". A própria relação sexual foi descrita por Carol como “sem importância”, uma vez que vê o marido “como um amigo”.

Eu ficava assim: "Gente, porque eu casei?" Porque ele é bom? Porque parecia que era uma coisa boa pra mim e realmente, pra mim ele é muito bom. [...] Você vê que ele gosta, ele gosta muito de mim... Muito mais do que eu dele, é, é... Mas assim, nunca foi aquele amor... Eu comecei namorar ele, fui namorando, fui namorando, de repente eu vi que ele era bom, que ele... Porque na verdade ele é um bom filho, ele é um bom irmão, ele é um bom amigo... Pensei: "Mas gente, ele é bom... Porque eu vou querer mais do que isso? Ele é bom” E foi... (Entrevista com Carol)

O significante "bom” estava bastante presente no discurso de Carol, tanto quando ela falava de seu marido quanto quando se referia ao ex-namorado de Manoela. A mãe contou 
que era um “menino bom”, e “até chorou” quando Manoela não quis mais namorá-lo. Insistiu para que a filha esperasse um pouco mais, pois poderia “aprender a gostar" do garoto. Manoela respondia que “não iria aprender a gostar” dele.

Não, ela tá certa... Depois eu fui vê que ela tava certa... Eu achava que ia dar certo... Até porque ele era muito bom, sabe? Eu achava: "Gente, mas ó, tá certinha ela". Porque lógico que você quer o melhor pro seu filho, né? (Entrevista com Carol)

Carol desejava que a filha fizesse como ela fez, de optar pelo "bom" e não pelo que queria: “Eu tinha, eu acho que eu tive isso de, de... Pode não ser o que eu quero, mas é o melhor pra mim.”

Eu tinha que pegar o que era bom, que ele era bom e os outros não prestavam, porque eu vou ficar com coisa que não presta? Eu tinha que pensar em mim. (Entrevista com Carol)

Quando questionada a respeito do que ela considerava “bom”, Carol definiu: “ser amigo, ser uma boa pessoa, não beber, não ofender, tratar bem”. Para ela, Rodrigo era um "bom filho e bom irmão", e Carol acreditou que ele seria também um "bom marido”. No entanto, se decepcionou com o fato de ele ser um "marido ausente".

O filho mais novo, de sete anos, foi mencionado por Carol como o membro da família com quem ela conseguia ter uma relação com mais demonstrações de afeto. Esse afeto, no entanto, trazia algumas conotações incestuosas:

Nele eu chego, eu beijo: "Meu bebê, meu amor, eu te amo", ele chega da escola ele joga beijo pra mim... Ele vai entrar no ônibus pra escola, ele joga beijo... Ele manda mensagem pra mim... Às vezes ele tá na casa da vó dele, ele manda mensagem: "Eu tô com saudade, meu amor" [...] Às vezes a noite ele deita na minha cama e: "Vamos namorar?". Todos os dias antes de dormir ele deita um pouquinho na minha cama e fala: "Vou namorar um pouquinho com você", aí fica lá, abraça um pouquinho, vai pro quarto dele e dorme.

Às vezes eu tô deitada na cama, eu falo: "Vem cá Manoela, me abraça, fica pertinho de mim. Vamos namorar?”. Aí fica um pouquinho ali, parece que é meio cômodo pra mim aquilo, não é tão... Tão agradável como é pra ele. (Entrevista com Carol) 
A mãe participava do grupo de familiares desde o início do tratamento de Manoela no GRATA. Sempre foi assídua e participativa, porém com um olhar pouco compreensivo para os sentimentos da filha: relatava que o transtorno alimentar era uma forma das pacientes receberem atenção dos pais. Quando eu, enquanto coordenadora do grupo, propunha pensarmos no que poderia estar faltando para as pacientes que podia estar fazendo com que elas buscassem atenção, Carol relatava que Manoela tinha ciúme do irmão mais novo, pois ela - a mãe - era mais ligada a ele. (Diário de campo, entrevista com Carol)

A partir dos relatos de Carol a respeito do distanciamento emocional do marido e da aproximação maior com o filho, pode-se pensar na vivência, por parte da mãe, de um vazio emocional - e físico, como exemplificado no "namorar na cama com a mãe" - que o filho parece ter sido inconscientemente encarregado de suprir.

\section{O despertar da feminilidade}

Manoela teve a primeira menstruação aos 11 anos de idade, e foi uma experiência que gerou muito medo.

Era assim, era de madrugada, eu levantei e fui no banheiro, aí quando eu fui no banheiro [risos], eu levei muito susto. Aí comecei chorar e chamar minha mãe, eu sabia o que era, mas eu fiquei com muito susto, aí chamei minha mãe, ela foi lá e me ajudou, tal. Só que aí eu tinha muito medo, mas eu tinha muito medo de aparecer na calça e tal, aí eu fui... Eu tinha muito medo, eu usava duas calcinhas, às vezes duas calças [risos]... (Entrevista com Manoela)

Contou que "odeia ficar menstruada" e tinha muita vergonha, por isso demorou muito tempo para contar para as amigas. Sentiu-se confortável para contar apenas quando soube que outras amigas também haviam menstruado.

Carol também descreveu uma relação com a filha de muita proximidade e abertura para conversas de vários tipos, desde escola até menstruação. Segundo o relato da mãe, Manoela contou para ambos os pais quando menstruou pela primeira vez, e falava com eles sobre as mudanças em seu corpo durante a puberdade. Relatou que "foi normal" ver a filha crescendo e desenvolvendo atributos femininos. 
Quando o peitinho dela tava nascendo ela contou pro pai dela. Até foi muito engraçado porque ele tava no sofá assistindo televisão, ela falou assim: "Pai, põe a mão aqui”, ele falou: “Não, pra quê?”, "Olha aqui pai, tá nascendo meu peitinho”, aí ele começou a rir... Aí ela deitou perto dele e falou: "Ai pai, essa fase de... De crescimento peitoral é muito difícil, dói muito viu?”. (Entrevista com Carol)

Ao relatar sobre a segunda internação de Manoela, Carol explicitou alguns conteúdos relacionados à vivência do ser mulher: como mãe e retentora do papel de cuidadora, sentia-se bastante sobrecarregada por ter que passar todo o tempo com a filha no hospital, sem dormir e sem se alimentar adequadamente. O marido trabalhava “de segunda à domingo", e não podia revezar com ela os cuidados para com a filha. A situação da internação ilustrou situações parecidas vivenciadas dentro de casa, com um marido “distante", bastante voltado ao trabalho, que não compartilhava com a esposa os cuidados da casa e dos filhos, ainda que Carol também trabalhasse fora.

Tive impressão de que Carol guardava uma série de insatisfações em relação ao casamento e a ser mãe. Ela trazia um discurso muito ambivalente: hora descrevia as qualidades do marido ("marido bom"), e hora relatava que sentia o marido muito ausente. Percebi que ela se sentia limitada, pois sempre contava com o marido para passar os finais de semana e fazer programas diferentes em família, mas como ele estava sempre trabalhando, não podia. (Diário de campo, entrevista com Carol)

Rodrigo, ao contar sobre a menarca da filha, comparou a notícia com a vez em que soube que Manoela estava namorando: "Foi estranho, mas foi menos do que do primeiro namorado (risos)”. Quando questionado a respeito de como é para ele ser pai de uma filha, Rodrigo fez comparações entre ver o filho e a filha namorando, mas não conseguiu descrever bem o que diferenciava um e outro.

Ah, num sei. Talvez, sei lá... Ah, num sei explicar. Aí é custoso, respondi tudo, essa você me pegou. Eu num sei falar, num sei... Ah, por questão do ciúme, né?... Né? Eu num... Num vou ter assim, eu acho que eu num vou ter ciúme do L. (Entrevista com Rodrigo) 
Evidencia-se, portanto, dificuldades emocionais do pai para pensar em questões relacionadas à sexualidade da filha.

\section{Relacionamentos afetivos e vida sexual}

Na época da entrevista, Manoela estava “de rolo” com um colega de sala, com quem já havia namorado durante dois meses. Haviam terminado por serem muito amigos, mais do que namorados, e continuaram sendo amigos, fazendo trabalhos da escola juntos, indo aos lugares juntos, entre outros. Depois de vê-la com outro menino, o ex-namorado pediu para voltar a namorar e ela aceitou, mas ainda é um namoro incerto.

Quando questionada sobre se o namorado havia sido o primeiro menino com quem ela havia "ficado", Manoela deu várias risadas e respondeu que não. Contou que tinha 11 anos quando "ficou” com um menino pela primeira vez, mas "nem sabia por que havia ficado com ele”, e foi conversar com sua mãe. Percebeu que era muito nova ainda, e demorou dois anos e meio para ficar com alguém novamente.

Ah, não sei, é porque foi meio assim, é... É... Não sei, foi meio que por tipo... Pressão, sabe? Meio que minhas amigas pegaram... Eu tava na festa junina da escola, tava vendendo correio elegante, tava vendendo correio elegante e elas tomaram a caixa da minha mão e me empurraram pra frente do menino. Aí o menino me agarrou e eu fiquei com ele [risos]. (Entrevista com Manoela)

Manoela não soube descrever o que sentia na época em que "ficou” com o menino pela primeira vez. Dizia apenas “sei lá”, de forma bastante reticente, como se não conseguisse acessar seus próprios sentimentos. Essa forma reticente de se expressar, que equivale ao conceito de “desafetação” (McDougall, 1991), indica dificuldade de manter contato com as próprias emoções. No caso de Manoela, a dificuldade era tanta que impedia até mesmo a identificação de prazer ou desprazer causada pela experiência de “ficar” com o garoto. Os “discursos prontos”, oriundos das pessoas do ambiente, substituíam sua própria possibilidade de pensar nas emoções. 
Em vários momentos da entrevista, tive a sensação de que Manoela reproduzia discursos prontos, que em minha fantasia vinham de falas da mãe. Manoela não conseguia descrever seus próprios sentimentos, era bastante reticente, repetia muito "sei lá". Pensei que ela parecia estar perdida entre o que sentia e os conselhos que ouvia da mãe, e ainda estava tentando se localizar, formar sua própria identidade. (Diário de campo, entrevista com Manoela)

Olha, não sei... Acho que tipo, não tem assim uma idade... Tem, mais ou menos... Mas eu acho que é meio tipo assim, você tem que tá pronta pro que você tá fazendo, porque às vezes você nem sabe o que você tá fazendo... Mas... Ai, não sei, também depois... Nesses dois anos e meio, eu não tinha vontade, sabe? De ficar com ninguém... Aí depois quando eu tive vontade, aí eu fiquei de novo. (Entrevista com Manoela)

Os dois anos e meio em que Manoela "não tinha vontade" de "ficar" com ninguém, foi quando o TA surgiu. Considerando-se que essa época coincide também com a menarca, pode-se pensar na dificuldade, já mencionada anteriormente, de lidar com o desenvolvimento psicossexual feminino durante a puberdade.

Manoela não havia tido relações sexuais. Quando questionada a respeito disso, respondia de forma monossilábica, como fosse algo proibido. Evidenciou-se importante componente religioso no discurso da participante, que citou o grupo de jovens como um local onde são discutidas questões a respeito de namoro e sexualidade, a partir "do lado cristão", que Manoela não soube explicar muito bem.

Ah, meio que tipo assim, é... Negócio de... É... Ai, como eu posso explicar... Tipo, o lado do amor, da família, da construção de uma família, desse negócio, desse lado assim, entendeu? (Entrevista com Manoela)

Logo em seguida, a participante relatou que “nunca conversa sobre isso”. A família nunca havia tido conversas a respeito de sexualidade. Manoela confidenciou que tinha algumas “dúvidas”, mas que acabava descobrindo as respostas na escola, quando "alguém comentava”. Porém, não tinha a iniciativa de perguntar nada, pois sentia muita vergonha assim como em relação a questões sobre menstruação. 
Manoela contou sobre uma amiga da sua idade que havia tido relação sexual sem proteção, e que depois ficou preocupada e pediu dinheiro emprestado para os amigos para comprar pílula do dia seguinte. A participante relatou que "não quis ficar dando sermão porque a menina estava muito mal, mas deixou claro que o que ela fez foi errado”. Quando questionada a respeito do conceito de "erro" a que estava se referindo, Manoela relatou que achava a amiga muito nova. Porém, não sabia dizer qual seria a idade adequada para ter relações sexuais, pois “ninguém nunca havia lhe contado”. Nota-se, novamente, a importância que a opinião e os ensinamentos externos têm para a formação do pensamento e das opiniões da participante, sendo difícil para ela pensar e chegar às suas próprias conclusões.

É, eu não sei, porque tipo assim, minha mãe nunca contou pra mim com quantos anos ela teve relação sexual, pela primeira vez. Meu pai também nunca contou, ninguém nunca contou pra mim, então não sei com quantos anos. (Entrevista com Manoela)

Carol sabia que a filha não havia tido relações sexuais, e falou de suas expectativas de que, quando ela tivesse, que fosse com alguém que "valesse a pena".

Depende da situação, de como for, de com quem for... Porque a gente tem medo de tipo assim ó... Porque isso não pode ser uma coisa tão fútil. Porque hoje em dia é fútil isso... É... Uma coisa muito assim... Vaga. As meninas de hoje... Elas encontram o moço aí, na primeira vez, nem conhece e já... É muito íntimo isso pra sair assim, eu acho muito íntimo, então eu não gostaria que fosse assim não. Eu gostaria que com ela fosse assim... Mais segura, com uma pessoa que valesse a pena. (Entrevista com Carol)

Para o pai, foi “estranho" quando a filha começou a namorar, mas não conseguiu expressar em palavras o que gerava incômodo, caracterizando os sentimentos apenas como “ciúmes”. Quando a pesquisadora solicitou que ele tentasse descrever um pouco melhor o que ele estava nomeando como “ciúme”, Rodrigo demonstrou entraves e reticências no discurso, indicando dificuldade de acesso aos conteúdos emocionais angustiantes.

Eu acho que é... A estranheza é essa... Foi, assim, é... Ela era menina, agora... Ela tá querendo... Já tá namorando. Mas você vai... Vai assimilando devagar. Aí eu não achei tão 
ruim não, depois... Porque eu... Faz parte da vida. É tem que ser compreendido. Num pode ter coisa errada, né? Eu num ia aceitar, mas... (Entrevista com Rodrigo)

Em seguida, ao ser questionado a respeito da sexualidade da filha, o pai demonstrou que tratava dessa questão a partir de aspectos concretos, especialmente relacionados à possibilidade de contração de doenças. Nota-se, portanto, o uso da racionalização como forma de não se aproximar emocionalmente de questões íntimas da filha.

Rodrigo também mencionou o medo de que a filha se envolvesse com alguém “mais velho e experiente", que poderia insistir para que Manoela "fizesse coisas que ela não tinha conhecimento”, “por malícia”. Citou, de forma reticente e superficialmente, suas próprias experiências sexuais, como se alguém pudesse fazer com sua filha o que ele fazia com as filhas de outros homens.

Num é fácil, né. Pra quem é pai assim... É lógico que vai ter, num... Num... Também num sou contra, né. Eu também já fui solteiro... Tive minhas namoradas e... Né... E o paiaço tinha pai (risadas) (pausa) Mas é assim... Mas eu penso que... Mas nunca faltei com o respeito. Nunca fiz nada com ninguém... Quer dizer, assim... (Entrevista com Rodrigo)

\subsection{Eixo II - Análise horizontal dos dados: Síntese integrativa das experiências vivenciadas}

O presente estudo teve como objetivo investigar o desenvolvimento da sexualidade e da feminilidade em adolescentes com TAs, buscando-se articular esses aspectos com os sintomas que caracterizam o quadro psicopatológico. A partir da análise das entrevistas das adolescentes, suas mães e seus pais, foram estabelecidas categorias temáticas referentes à síntese dos temas convergentes e divergentes nos relatos dos participantes. Como pode ser observado no mapa de associação de ideias a seguir (Figura 8), as categorias foram agrupadas segundo o papel que cada participante do estudo desempenhava na família, a saber: filhas, mães e pais, além das duplas mãe-filha, pai-filha e casal parental. 


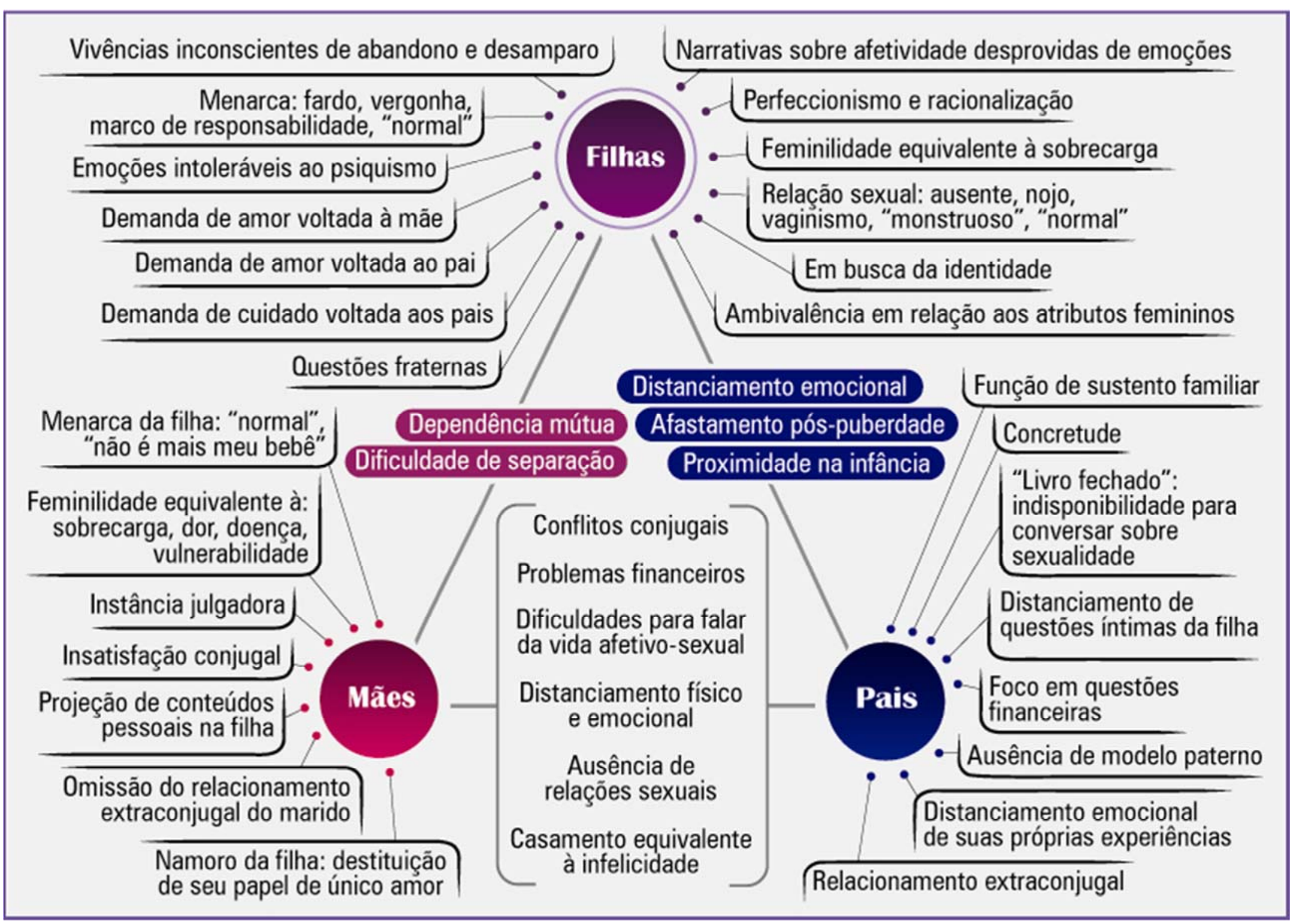

Figura 8. Mapa de associação de ideias confeccionado a partir da análise das entrevistas das filhas, mães e pais. 
A seguir, as categorias ilustradas na Figura 8 serão discutidas e analisadas sob a luz do referencial teórico adotado no presente estudo, a saber, a Psicossomática Psicanalítica de Joyce McDougall (1991, 1997). Para fins didáticos, as categorias serão realçadas em negrito.

A impossibilidade de tolerar sentimentos e emoções intensos para o psiquismo emergiu como dado frequente e marcante tanto no relato manifesto das participantes, quanto na forma reticente e, em alguns casos, evasiva de se expressar. As anotações no diário de campo, em sua maioria, englobavam impressões de fechamento emocional, que remetiam a pesquisadora a sentimentos de vazio e emoções ausentes - suprimidas ou recalcadas. No entanto, evidenciou-se que tais emoções intoleráveis ao psiquismo não incluíam apenas conflitos internos e angústias, mas também emoções geradoras de prazer, tais como o amor romântico ou a própria vida afetivosexual. As narrativas sobre afetividade eram desprovidas de emoções, indicando a dissociação dessas experiências com o possível prazer que poderiam gerar.

McDougall (1991) propõe que a incapacidade de manter contato com as próprias emoções também se aplica a emoções e afetos geradores de prazer, não apenas de sofrimento, e é característica típica da desafetação. A autora sugere que a vivência afetiva não pode ser transmitida por meio da linguagem - o que pode ocorrer tanto em situação de psicoterapia analítica, quanto em situação de entrevista, como é o caso das participantes deste estudo quando experiências emocionais são dispersas sob a forma de ações. A impossibilidade de vivenciar o próprio desejo e, consequentemente, o prazer, pode estar intimamente relacionada com o comer compulsivo da BN, que McDougall (1991) denomina como "solução aditiva”: o comportamento aditivo teria como objetivo “afastar da consciência as experiências psíquicas insuportáveis e impossíveis de suprimir porque a força dos afetos em jogo e sua natureza conflituosa suscitavam confusão” (p. 107).

Dentre as experiências que McDougall (1991) denomina como “experiências psíquicas insuportáveis”, para as participantes deste estudo, incluem-se aquelas relacionadas à 
sexualidade. $\mathrm{O}$ ato sexual, para as mulheres, implica fundamentalmente entrar em contato com o luto pelo corpo infantil e com a vivência do corpo feminino. Portanto, ao abrir-se para a sexualidade, as adolescentes estariam aceitando o devir da feminilidade, com todas as suas vicissitudes, dores e delícias. Para as participantes deste estudo, o luto pelo corpo infantil e o consequente luto pelos pais da infância é insuportável e, por tal motivo, as relações sexuais variam entre ausentes, “monstruosas”, geradoras de nojo, de dor - vaginismo - ou, por fim, como “normais”, no sentido reticente e desafetado já mencionado anteriormente.

Segundo Halberstadt-Freud (2001), o início da adolescência, para a menina, é marcado por novos desafios: estímulos libidinais para a heterossexualidade e a necessidade de se separar da mãe. Tais estímulos contradizem o que as participantes deste estudo haviam vivido até aquele momento, ou seja, a ilusão simbiótica com a mãe e o desejo de permanecer como sua extensão, satisfazendo-a e sendo, por sua vez, satisfeita. Buscando defender-se desses estímulos aflitivos, a adolescente retira-se para padrões de comportamento mais conhecidos, ou seja, voltando-se para a segurança da relação com a mãe. Consequentemente, a sexualidade torna-se algo “impuro”, dando origem à vergonha e à culpa.

No caso de Sofia, Helena e Maria, observam-se entraves no processo de genitalização. Sofia, ao se referir à relação sexual, relatava "sentir nada", Helena demonstrava-se inacessível para qualquer pensamento relacionado à sexualidade: “Acho que eu tenho tanta coisa na cabeça que não dá espaço” e Maria, por sua vez, sentia muita dor com a penetração peniana, e esta dor foi nomeada pelos médicos de "vaginismo". Considerando-se que a entrada na adolescência envolve fundamentalmente o acesso à genitalização e a revivência da situação edipiana infantil, pode-se compreender o sintoma anoréxico como uma recusa ao encontro com o genital (Gaspar, 2010). Tal recusa se traduz como resistência ao desenvolvimento, à saída do mundo infantil e, por consequência, à genitalidade. Esses pressupostos se aproximam das ideias de McDougall $(1991,1997)$ no sentido de que a recusa 
- e o consequente adoecimento físico - emerge como defesa contra algo "ameaçador da integridade psíquica” (Gaspar, 2010, p. 54). A jovem com AN regride e mantém um investimento narcísico em seu corpo de criança - que pode ser observado pelo corpo esquálido e deserogenizado -, resultado da impossibilidade de conter e simbolizar o excesso pulsional vivenciado na adolescência.

A questão da imagem corporal também se encontra bastante presente na vivência da sexualidade de mulheres com AN (Ghizzani \& Montomoli, 2000). As complexas atitudes das mulheres com AN frente aos seus corpos remetem à recusa do amadurecimento físico e genital e, consequentemente, remetem também à recusa da própria sexualidade. Em consonância com os comportamentos de retraimento, ansiedade e isolamento social geralmente decorrentes do incômodo com a percepção da autoimagem -, encontram-se as condutas evitativas em relação aos relacionamentos íntimos, afetivos e sexuais. Além disso, levando-se em consideração o importante aspecto da cultura sobre a manutenção dos TAs, os sintomas parecem estar também relacionados com a adequação às normas impostas pela tradição cultural em relação aos papéis femininos, sendo considerados meios inconscientes de resolução de conflitos de identidade sexual (Hoskins, 2002; Romejko-Borowiec, 2004). A autora considera que, ao desenvolver um transtorno desse tipo, as mulheres podem evitar e/ou prorrogar a necessidade de confrontar-se com os papéis exigidos das mulheres adultas.

A feminilidade vem sendo apontada pela literatura científica (Behar, Barrera, \& Michelotti, 2003; Matthews-Ewald, Zullig, \& Ward, 2014; Meyer, Blisset, \& Oldfield, 2001; Moore \& Keel, 2003; Woolhouse, Day, Rickett, \& Milnes, 2012) como fator de risco para a ocorrência de TAs. Os autores mencionados partem do sistema de crenças e comportamentos atribuídos ao sexo masculino e feminino pela sociedade, ponderando que tais atribuições culturais podem se tornar bastante aversivas para alguns indivíduos. Segundo Hepp, Spindler e Milos (2005), o papel de gênero pode ser definido como a posição que o indivíduo assume 
como ser masculino ou feminino, tomando como base os conceitos socialmente construídos acerca do estereótipo cultural desses construtos, ou seja, os comportamentos, atitudes, interesses e características de personalidade considerados tipicamente masculinos ou femininos. Segundo Heenan (2005), atualmente, as mulheres crescem em um meio sociocultural no qual a felicidade e o bem-estar são equiparados ao fato de serem magras. Os estudos de Green et al. (2008) e Woolhouse et al. (2014) demonstrou que corpos magros são geralmente retratados pelas mulheres como símbolo de sucesso social, econômico e cultural, enquanto que restrição e abnegação alimentar indicam controle, autodisciplina e virtude moral. A gordura era considerada marca de desvio, ausência de autodisciplina e algo a "ser queimado” e expurgado; alimentação era tomada como fonte de culpa e vergonha, e comida era equiparada a algo pecaminoso e um inimigo a ser derrotado. Portanto, para as mulheres, as responsabilidades atribuídas ao papel de gênero feminino são emocionalmente densas e exercem influência direta na vivência da imagem corporal. Ao sentirem que não conseguem cumprir as exigências culturais femininas, os sentimentos negativos parecem culminar, muitas vezes, em insatisfação corporal e psicopatologias alimentares (Behar, Barrera, \& Michelotti, 2003).

Indo além da concepção da recusa à feminilidade e à genitalidade como importantes fatores na gênese dos quadros de TAs, alguns autores (Capitaine, Rogers, \& Chabrol, 2011; Castellini et al., 2013) propõem a contrapartida de que as experiências sexuais negativas podem exercer impacto sobre a imagem corporal, levando à vivência de emoções negativas em relação à feminilidade e à sexualidade que, por sua vez, podem precipitar a ocorrência de sintomas alimentares. Assim, nota-se que questões relativas à sexualidade encontram-se presentes nos quadros TAs tanto pelo viés da precipitação do quadro - tomando-se a restrição alimentar como forma de evitar o desenvolvimento dos atributos femininos - quanto pelo viés 
da manutenção - quando as jovens acometidas têm relações sexuais percebidas como negativas, os sintomas de TAs se acentuam.

A literatura psicanalítica que trata do tema da sexualidade feminina (Birksted-Breen, 2005; Gaspar, 2010; Halberstad-Freud, 2001; Kehl, 2008; Miranda, 2011; Ribeiro, 2011) propõe que a dificuldade do acesso à genitalidade e a manutenção do corpo infantil podem ser decorrentes da dificuldade de separação da mãe e do medo da perda de seu amor. No presente estudo, evidenciou-se a contrapartida da mãe, que também apresenta dificuldades de separação da filha, resultando em dependência mútua. É possível estabelecer relações entre essa dependência e o controle mútuo, tão presente nas relações entre mãe e filha com TA (Campos et al., 2012). Quanto mais fusionada é a dupla, maior o desejo de controle uma da outra e, consequentemente, maior a dependência. O intenso grau de controle e dependência gera graves dificuldades de separação, levando ao aniquilamento e impossibilidade de individuação de ambas as partes.

Além de questões de vazio narcísico da mãe e conteúdos maternos não elaborados transmitidos transgeracionalmente, os dados também indicaram que a dependência da mãe em relação à filha acontece principalmente quando há conflitos conjugais parentais, distanciamento físico e emocional entre o casal, ocorrência de relacionamento extraconjugal por parte do marido e, de maneira geral, quando o casamento emerge no relato como equivalente à infelicidade. Nos casos das famílias Moraes e Teixeira, o relacionamento extraconjugal do pai e o consequente distanciamento emocional do casal parental parecem ter proporcionado espaço para que a mãe se aproximasse da filha, tornandoa seu objeto de completude. Nesse sentido, a menarca, o namoro e a sexualidade da filha passam a configurar ameaças à própria integridade emocional da mãe, que parece não saber viver sem a filha: "Se ela também me largasse pra lá, eu acho que eu não ia dar conta" (Entrevista com Luana). 
Os conflitos conjugais e o desejo de separação foram abertamente mencionados pelos casais das famílias Moraes, Garcia e Ribeiro, e citados de forma bastante ambivalente pelo casal Freitas. Entretanto, os casais das famílias Batista, Paiva e Teixeira se mostraram bastante fechados para relatar conteúdos referentes às suas próprias vidas afetivo-sexuais. Tal fechamento remete à impossibilidade de relatar, registrar (frente ao gravador) e, principalmente, pensar nos problemas conjugais. O casal parece deixar de existir enquanto tal, passando a existir apenas como duas pessoas unidas em prol do cuidado e sustento dos filhos. Segundo Latzer, Hochdorf, Bachar e Canetti (2002), pai e mãe devem ser observados enquanto unidade parental, uma vez que esta unidade exerce impacto sobre o psiquismo dos filhos. Inconsistências na unidade parental - ainda que existentes apenas na latência e não no plano manifesto - podem resultar em dificuldades no desenvolvimento de vínculos afetivos por parte da filha, uma vez que os vínculos dentro da própria família são frágeis e vulneráveis, e se reproduzem nas relações objetais da geração seguinte.

A demanda de amor voltada ao pai, percebida no relato de cinco participantes, também pode ser considerada como fator de manutenção do corpo infantil e de evitação inconsciente do acesso à genitalidade. Os pais - genitores do sexo masculino - se mostraram como "livros fechados", ou seja, revelaram marcada indisponibilidade emocional para conversar sobre sexualidade, tanto a sua própria quanto a das filhas. Também mostraram bastante concretude, ou seja, se mostraram bastante apegados ao aspecto concreto - e muitas vezes financeiros - das vivências familiares. Muitos confidenciaram que mantinham relação próxima com as filhas quando estas eram crianças, mas se afastaram durante a puberdade, sem poder nomear razões para tal afastamento. Nota-se a existência de resistências paternas para entrar em contato com o desenvolvimento psicossexual das filhas, e hipotetiza-se que essas resistências encontram-se no cerne da infantilização das mesmas, que se mantêm regredidas a uma época do desenvolvimento em que os pais conseguiam se aproximar delas. 
A fantasia inconsciente da perda do amor do pai durante a puberdade é colocada em evidência, o que parece gerar prejuízos na autoimagem e na experiência da própria feminilidade, impedindo que as filhas se posicionem enquanto mulheres e vivenciem sua sexualidade de forma saudável.

Elliot (2010) propõe que a simples chegada da puberdade, por si só, faz com que as pré-adolescentes vivenciem a dolorosa perda do amor do pai e sintam-se abandonadas. Além disso, para a autora, quanto mais inconsistentes e inseguros forem os laços entre pai e filha, maior a dificuldade de separação e individuação da filha, o que facilitaria o desenvolvimento de sintomas psicossomáticos.

A forte aliança entre mãe e filha faz com que estas se isolem do mundo, existindo apenas quando dentro da ilusão simbiótica criada (Gorgati, 2002). Frente a tal isolamento, o pai seria o que a autora nomeou como "objeto-esboço" que "serve para confirmar a fidelidade do relacionamento com a mãe” (p. 119). Nesse sentido, nenhum homem poderia fazer parte da vida da filha ou "substituir” o pai, uma vez que este último não alcança o status de objeto a ser desejado. No entanto, os dados do presente estudo divergem do que é proposto por Gorgati (2002) a respeito do status paterno no psiquismo da filha: o relato da maioria das participantes (filhas) trouxeram conteúdos latentes de intenso sofrimento por não se sentirem amadas pelo pai, e por perceberem o afastamento deste durante a puberdade.

Em contrapartida, um dado convergente com o que foi proposto pela mencionada autora - além da forte aliança entre mãe e filha - é a impossibilidade da entrada de um outro homem na vida das filhas, que pode ser observada pelo empobrecimento da vida afetiva e sexual das participantes. Evidencia-se, portanto, a necessidade de se sentir amada pelo pai para que possa se deixar ser amada por - e amar - outro homem.

O modo como os pais deste estudo lidaram com a menarca da filha envolvia desconhecimento que, subjetivamente, remetia a um temor, que pode estar relacionado com 
o afastamento entre pai e filha na época da puberdade desta última. Wallace relatou um temor explícito, relacionado ao tabu do incesto: tinha medo de trocar a fralda da filha quando esta era bebê e nunca havia visto a filha “tomar banho peladinha” em sua frente. José, por sua vez, quando questionado a respeito da primeira menstruação da filha, se manteve apegado à concretude dizendo que era algo "natural", mas que poderia ter sido em idade mais tardia para não "prejudicar o crescimento". Cido, Pedro, Ronaldo e Rodrigo acreditavam que assuntos sobre sexualidade e menstruação deveriam ser conversados entre mãe e filha, colocando-se em posição de distanciamento de questões íntimas da filha e aproximando-se apenas da função de sustento familiar. É possível perceber, portanto, a tentativa inconsciente de afastamento dos pais - genitores do sexo masculino - dos conteúdos relacionados à feminilidade da filha, incluindo menarca, sexarca, namoro, entre outros.

O distanciamento do pai durante a adolescência da filha foi descrito por Elliot (2010) como fator que dificultava que esta última pudesse lidar emocionalmente com as mudanças corporais geradas na puberdade, e também com as mudanças relativas à dimensão ambiental e relacional. Tal distanciamento paterno pode estar ligado, segundo Costa (2014), às árduas tentativas dos pais para impedir que seus conteúdos afetivos se manifestem. A mencionada autora sugere que os genitores masculinos de mulheres com TAs apresentam marcados comportamentos evitativos, pouca expressão de afetividade, dificuldades em reconhecer a gravidade dos sintomas da filha e tentativas de ocultar os conflitos familiares. Trata-se, portanto, de homens distanciados de suas próprias experiências emocionais, que negam suas próprias necessidades, possivelmente com o objetivo inconsciente de atenuar a angústia envolvida (Costa, 2014). Hipotetiza-se que, não tendo condições mentais para lidar com suas próprias angústias, os pais de jovens com TAs também estão desprovidos de recursos emocionais para lidarem com as angústias maciças da filha, preferindo se distanciarem. 
De acordo com McDougall (1997), a atitude do pai de delegar à mãe a função de conversar com as filhas sobre questões mais tipicamente femininas pode estar relacionada ao terror masculino à feminilidade, que pode impedir que o pai se aproxime da filha e aprecie seu corpo de menina. Sem pais para guiarem sua experiência em relação ao próprio corpo, de forma a erotizá-lo, a filha pode se sentir desamparada para lidar com as angústias genitais e, assim, criar uma imagem narcisicamente prejudicada de seu self e de sua sexualidade. Evidencia-se, portanto, a importância do pai no desenvolvimento psicossexual da filha e as possíveis repercussões negativas do afastamento paterno nesse momento.

Tanto para as mães quanto para as filhas foi difícil expressar sentimentos relacionados à menarca. Algumas relataram ter sido uma experiência "boa" e terem se sentido “orgulhosas” da filha. Luana, porém, confidenciou sentimentos ambivalentes: sabia que era "normal” a filha ter a primeira menstruação e que "já estava esperando"; por outro lado, sentiu-se angustiada ao perceber que a filha estava crescendo, deixando de ser "aquela criancinha". A possibilidade da filha se tornar mulher adulta e independente parece ser vivenciada como possibilidade de abandono e desamparo, de ser deixada sozinha. Esse dado corrobora a literatura que trata da relação mãe e filha nos TAs (Lawrence, 1991; Miranda, 2011).

No entanto, caminhando para além da questão da filha como objeto de completude narcísica materna, foi percebido que a entrada na adolescência - e consequentemente na sexualidade - envolvia uma aproximação do feminino que, até o momento da menarca, as mães ainda não haviam precisado lidar. Ao menstruar pela primeira vez, as filhas estavam comprovando sua feminilidade que, para algumas mães deste estudo, era inconscientemente percebida como vulnerabilidade, dor, doença e sobrecarga. Tal concepção a respeito da feminilidade corroboram os pressupostos de Campos et al. (2012), que propõem que as mães de jovens com TAs tiveram dificuldades com suas próprias mães no que diz respeito ao 
desenvolvimento e à vivência da feminilidade e, portanto, encontram-se impossibilitadas de oferecer um modelo identificatório feminino para suas filhas. Trata-se de reatualizações de antigas patologias, transmitidas e não elaboradas por mulheres de várias gerações (Azevedo, Fères-Carneiro, \& Lins, 2015), e que mantém direta relação com os sintomas alimentares das filhas.

Essa categoria de análise pode ser observada na associação que a mãe de Golita fazia entre o seio (característica marcadamente feminina) e doença: a participante passou muito tempo de sua vida acreditando que aqueles atributos femininos que estavam se desenvolvendo nela fariam com que ela adoecesse. Ainda que essa ideia tenha sido desmentida posteriormente, acredita-se que as marcas da feminilidade considerada ameaçadora tenham permanecido em seu psiquismo e sido transmitidas inconscientemente para a filha. Esta, por sua vez, mencionou várias vezes na entrevista a aversão ao seio. O sintoma de aversão aos atributos femininos, principalmente o seio, surge como duplamente determinado para Helena: desejo intenso de emagrecer - e assim, portanto, eliminar tais atributos, e também como identificação inconsciente à mãe e à avó. No ódio ao seio, hipotetiza-se também o repúdio inconsciente à relação com a mãe, tanto em termos de identificação com o gênero quanto da própria vinculação emocional, cuja primeira aproximação se deu por meio do seio da mãe, na amamentação. A relação com o seio da mãe - e, consequentemente, com o corpo da mãe como um todo -, configura uma relação erótica inaugural, sendo que a possibilidade de usufruir da sexualidade depende da capacidade de transformação dessa relação erótica com a mãe (Ribeiro, 2011). A autora pontua: "Para que exista uma relação fértil com um homem é necessário manter-se em uma tensão dialética entre o afastamento e a proximidade identificatória com a mãe” (p. 30).

Ao fantasiar que o seio era doença, pode-se pensar na forma como a gravidez foi vivenciada por Golita: hipotetiza-se que o feto, na medida em que crescia dentro dela, 
também poderia ter sido encarado como “doença”, inserindo a filha em um lugar imaginário de algo temido, “indesejado” e profundamente repudiado. A filha, por sua vez, parece se identificar com esse lugar que lhe foi inconscientemente atribuído ao se tornar de fato um ser doente, na passagem da infância para a adolescência, período em que teve que fazer remanejamentos libidinais e rearticular sua imagem corporal sob a égide da identificação com a figura materna.

No relato das filhas, a menarca foi descrita como: “normal”, um “marco de responsabilidade" uma “vergonha” e/ou um “fardo". A menarca marca a entrada na puberdade e, portanto, o início das vivências relativas à sexualidade, etapa em que a menina deve se adaptar às mudanças no corpo e às novas demandas da maturidade sexual (Ruuska et al., 2003). Nesta pesquisa, sentimentos positivos não foram associados à experiência da menarca. O elemento da feminilidade parece carregar, para as participantes deste estudo tanto mães quanto filhas -, a marca de um trauma. A menstruação enquanto "ritual de iniciação espontâneo” (Gaspar, 2010, p. 56), algo que acontece sem que a pré-adolescente deseje, parece ser controlado por meio do TA, especialmente da AN. Nos casos de AN, a amenorreia e o intenso emagrecimento - que inibe o desenvolvimento dos atributos femininos - garante que a menina se mantenha como criança, expressando, portanto, uma defesa contra a feminilidade.

André (2001) sugere que a feminilidade apresenta a característica de vulnerabilidade pelo fato de que a vagina configura um orifício, pelo qual qualquer coisa pode entrar e de onde pode sair, muitas vezes sem o controle da menina - por exemplo, o sangue menstrual. Tal orifício convida as defesas narcísicas a protegerem a jovem da brecha que se abriu, uma vez que esta representa a ameaça de que a menina poderá ser invadida e penetrada. Essas representações geram mecanismo defensivos que, no caso das jovens com AN, é recusar e mascarar a feminilidade, esta feminilidade que coloca a integridade psíquica em perigo 
(Gaspar, 2010). A jovem com AN fecha todas as "saídas”: boca e orifício vaginal. A jovem com BN, por sua vez, “responde pelo ato de preencher” (André, 2001, p. 37).

Os relatos das filhas traziam vários conteúdos latentes sobre vivências de abandono e desamparo, principalmente por parte dos pais. Em contrapartida, pais e mães referiram em suas entrevistas sentimentos de muita preocupação com as filhas e desejo de cuidado. Independentemente do abandono e do desamparo percebidos pelas filhas envolverem ou não dados de realidade, é importante considerá-los como vivências significativas e geradoras de profundo sofrimento, que podem ter suas raízes em épocas muito primitivas do desenvolvimento psicossexual. Winnicott (1945/2000) propõe que mais do que uma mãe fisicamente presente, é necessária uma mãe que ajude o bebê a sair do estado de nãointegração, quando ainda não é capaz de diferenciar o “eu” do “não-eu”. A mãe precisa estar constantemente atenta às necessidades do bebê e fornecer-lhe os objetos dos quais ele precisa (ilusão) e, apenas quando o bebê já está mais seguro de que possui um corpo que pode ser instrumento de transformação do mundo, a mãe deve frustrá-lo (desilusão). Segundo Costa (2014), as falhas consecutivas da mãe em satisfazer as necessidades básicas do bebê podem fazer com que ele vivencie angústias ainda insuportáveis para seu psiquismo, impedindo que ele internalize uma figura materna suficientemente boa e, consequentemente, sentindo-se desamparado e angustiado em vários momentos ao longo da vida.

Por fim, no presente estudo, ressaltaram-se dificuldades na diferenciação de necessidades pessoais e necessidades da filha. Foram evidenciadas várias projeções de conteúdos pessoais nas filhas, assim como a reprodução de padrões de relacionamento oriundos da família de origem dos pais, que eram predominantemente rígidas. Mães reproduziam com as filhas a rígida educação que haviam recebido dos pais: "Ela [filha] é muito diferente, ela fugiu da regra. Da minha regra, do que eu sou, do que eu aprendi, do que eu acho certo.” (Entrevista com Márcia). Essa reprodução de conteúdos da família de origem 
incluía tanto desejos e aspirações (por exemplo, a festa de 15 anos de Ana Júlia, que era o sonho da mãe), quanto medos e valores relacionados à sexualidade. Todas as mães entrevistadas mencionaram o medo de que "algo ruim" - que não pôde ser nomeado acontecesse às filhas, além dos tabus transmitidos transgeracionalmente, tais como: perder a virgindade antes do casamento, entrar no quarto de um menino, "ficar até tarde na rua", passar a noite na casa do namorado, entre outros.

Segundo Borges e Magalhães (2011), entre uma geração e outra se transmite uma realidade, um mundo de hábitos e significados que faziam sentido para a geração anterior. No entanto, a forma como tal realidade é transmitida pela mãe pode, muitas vezes, ser invasiva e devastadora para o psiquismo da filha. Esse dado pode ser observado na contrapartida de Flávia, que demonstrava curiosidade a respeito dos conteúdos que a mãe tratava como tabus. As expectativas de Márcia para com a filha são da ordem do narcisismo, no qual a mãe espera que a filha aja da forma que ela considera correta, e que é a forma que ela própria vivia desde o início da vida. Trata-se, portanto, de uma mãe narcisicamente insatisfeita (Ribeiro, 2011), que espera que a filha atenda suas necessidades e atenue suas próprias frustrações. De acordo com Winnicott (1983, 2008), quando a mãe desconsidera as necessidades do bebê e passa a cuidar deste a partir das suas próprias necessidades, o cuidado é vivenciado como intrusivo e o bebê tenta proteger o self: Flávia, em contrapartida às atitudes da mãe, tenta a todo momento romper com as expectativas narcísicas da mãe, e a sexualidade emerge como a forma mais explícita de ataque à mãe. Tais ataques podem interpretados como tentativa de gerar a própria existência, não mais como extensão da mãe.

Ribeiro (2011) propõe que o desejo de ter filhos e o exercício da maternidade estão relacionados ao vínculo primário da mulher com sua mãe da infância, e constitui uma questão central no psiquismo feminino e na construção da feminilidade, tanto da mãe quanto o bebê que está para nascer. A maternidade tem a função primordial de trazer mudanças nas 
identificações da mulher com a figura materna, o que justifica a ocorrência da projeção de conteúdos pessoais na filha, com o objetivo inconsciente de encontrar resoluções para possíveis conflitos vivenciados na relação da mulher com sua própria mãe.

O presente estudo fornece dados empíricos para subsidiar a possibilidade de ir além do que foi até então proposto pela literatura científica a respeito da maternidade, que enfatiza a importância do papel da mãe enquanto função estruturante do psiquismo da criança: a demanda de amor voltada ao pai, demonstrada por várias participantes ao longo desta pesquisa, indica que a relação com este genitor exerce importância crucial no psiquismo das jovens mulheres e no desenvolvimento da feminilidade. Assim, o exercício da maternidade, além de envolver a repetição inconsciente - com busca de resolução - de conflitos com a mãe da geração anterior, também engloba a relação estabelecida com o pai da infância, uma vez que esta relação é estruturante para o estabelecimento da identidade da menina enquanto mulher. Nesta pesquisa, os genitores do sexo masculino foram retratados como bastante focados nos aspectos financeiros da família e no sustento familiar, distanciados de questões íntimas das filhas, e voltados para os aspectos concretos das experiências. Essas características, juntamente com o afastamento do pai na época da puberdade, parecem estar relacionadas com as vivências de abandono e desamparo das filhas. Tais vivências marcam intensamente o psiquismo destas, e podem ser revividos quando a feminilidade é colocada em questão - como no caso da maternidade. 


\section{CONSIDERAÇÕES FINAIS}

O presente estudo teve como objetivo investigar o desenvolvimento da sexualidade e da feminilidade em mulheres com TAs, buscando-se articular esses aspectos com os sintomas que caracterizam o quadro psicopatológico. A partir da análise dos dados, de maneira geral, evidenciouse que as participantes (filhas) se mostraram bastante reticentes e evasivas, sem espaço mental para elaboração de sentimentos e emoções intensas. Os relatos sobre afetividade eram especialmente desprovidos de emoção, uma vez que falar sobre namoro e sexualidade implicava, necessariamente, em entrar em contato com o luto pelo corpo infantil e com a dificuldade de vivenciar o corpo feminino. As relações sexuais eram ausentes, “nojentas” e/ou “monstruosas”, o que indica o quanto o acesso à genitalidade pode ser “monstruoso” para as jovens deste estudo.

A impossibilidade do acesso à genitalidade emergiu como resistência ao desenvolvimento psicossexual, sendo substituído pelo investimento narcísico no corpo infantil como resultado da não-contenção e não-simbolização do excesso pulsional típico da adolescência. Nesse contexto também pode ser incluído o medo da perda do amor da mãe, que tomava a filha como extensão narcísica, principalmente nos casos em que havia histórico de conflitos conjugais e relacionamentos extraconjugais por parte do pai. Mães narcisicamente insatisfeitas tomavam as filhas como extensão de si mesmas, sendo que estas tinham a responsabilidade - transmitida inconscientemente - de realizar os projetos narcísicos da mãe. Evidencia-se, portanto, a importância da consistência na unidade parental para que a filha possa desenvolver vínculos afetivos saudáveis.

Elementos transgeracionais também foram identificados neste estudo: mães cuja feminilidade foi desvalorizada ou prejudicada na relação com suas próprias mães encontravam entraves psíquicos para vivenciar o processo de tornar-se mulher. Como consequência, essas mães apresentavam dificuldades para servir de modelos identificatórios 
femininos para suas filhas, desenvolvendo uma relação baseada no controle, dependência e aniquilamento das individualidades.

Os genitores do sexo masculino foram caracterizados como emocionalmente distantes, voltados para a concretude e para o mundo trabalho, e responsáveis por prover o sustento da casa. Portanto, no que diz respeito à função paterna, as famílias se inseriam nos moldes antigos que ditavam o exercício da paternidade, nos quais o pai permanecia à margem da família nuclear, sendo a autoridade responsável pela provisão financeira e mantendo relativo distanciamento das questões internas da casa e da dinâmica familiar. Trata-se de homens com distanciados de suas próprias experiências emocionais e, consequentemente, com dificuldades de se aproximarem de aspectos emocionais e íntimos tanto da filha, quanto da própria relação conjugal estabelecida com a esposa.

A ocupação da filha do lugar de extensão da mãe, com o objetivo de suprir sua falta narcísica, era muitas vezes favorecido pelo distanciamento emocional do pai, que elegia a mãe como única responsável pelo cuidado filha. Evidencia-se que os pais (genitores do sexo masculino) deste estudo não exerciam a função de interditores da relação mãe-filha, função necessária para a passagem saudável pelo complexo edípico e para a construção de um espaço simbólico no psiquismo do bebê. A impossibilidade de exercer a função de interditor é uma via de mão dupla: surge em decorrência de dificuldades do próprio pai em se aproximar e se impor de maneira adequada, e também da própria relação estabelecida entra a mãe e a filha, que se fecham em uma dupla onde nada e ninguém entra - nem o pai, e muitas vezes nem os profissionais de saúde.

Os pais (genitores do sexo masculino) também se mostraram indisponíveis para falar sobre a sexualidade das filhas e com as filhas. Todos confidenciaram terem sido mais próximos de suas filhas durante a infância, tendo se afastado na época da puberdade. Nota-se que havia resistências, por parte dos pais, para entrar em contato com o desenvolvimento psicossexual da filha. Assim, hipotetiza-se que a demanda de amor voltada ao pai configura 
um dos principais fatores responsáveis pela manutenção do corpo infantil das filhas: estas pareciam se prender à infância, época durante a qual os pais conseguiam se aproximar delas. A fantasia inconsciente da perda do amor do pai parece impedir, portanto, que as filhas experienciem a feminilidade como uma experiência positiva e que, por meio da identificação com a mãe, elas possam se posicionar como mulheres.

Neste estudo seguimos o pressuposto básico de que existem motivações inconscientes que direcionam a vida sexual e amorosa das pessoas sem que elas percebam. O tipo de vínculo estabelecido entre pais e filhos, permeado por experiências reais e fantasias inconscientes, é preponderante na gênese da identidade sexual. O excesso, seja de privações quanto de prazer vivenciados nessas relações básicas, exerce influência nos processos identificatórios e nas escolhas objetais da criança, sejam no sentido da orientação hetero ou homoafetiva. Nos casos analisados, o desejo impositivo de uma mãe e a postura omissa do pai parecem colaborar decisivamente na formação da identidade das filhas e mantém íntima relação com a ocorrência do quadro psicopatológico.

Esta pesquisa oferece contribuições para a compreensão da complexidade da gênese dos TAs, considerando-se que, do ponto de vista da psicanálise, são quadros que envolvem aspectos emocionais muito primitivos, que vão além da insatisfação com o corpo, da restrição alimentar, do uso de métodos purgativos e da influência da cultura sobre o psiquismo das mulheres. Os dados oriundos da análise das tríades edípicas demonstraram a importância da identificação das filhas com a feminilidade das mães, e o quanto a ausência desse modelo identificatório dificulta o devir da feminilidade nas filhas. Sendo quadros que envolvem dinâmicas psíquicas essencialmente femininas, os TAs precisam ser observados e tratados a partir de concepções mais amplas. Vale ressaltar que não se trata de culpabilizar as mães: é importante reconhecer que essas mulheres são moldadas por histórias pessoais de sofrimento, violência e/ou distanciamento emocional de seus próprios pais, e que esse contexto se dá a 
partir de inúmeros conteúdos não elaborados, acumulados e transmitidos dentro das famílias por várias gerações.

Considerando esses pressupostos relativos à complexidade dos TAs e de sua relação com questões de feminilidade, identidade psicossexual e relações familiares, o presente estudo fornece subsídios para refletir sobre as intervenções clínicas atualmente utilizadas no tratamento desses quadros. Os aspectos mencionados só podem ser devidamente endereçados e tratados por profissionais que têm um olhar voltado para a psicodinâmica das pacientes e dos familiares. É importante que os serviços de saúde ofereçam tratamento psicológico também para os familiares, seja no formato de psicoterapia individual ou familiar. Além disso, os profissionais devem ter uma compreensão da psicodinâmica comum entre famílias com um membro com TA, pois essa mesma dinâmica pode se repetir transferencialmente com a equipe, e os profissionais devem ser capazes de reconhecer os sentimentos contratransferenciais despertados, elaborá-los e devolvê-los para a família buscando gerar mudanças e favorecer o tratamento.

Por fim, ainda do ponto de vista das recomendações para a prática clínica, a partir dos achados do presente estudo, deve-se destacar o lugar especial que a psicoterapia ocupa no plano terapêutico das pacientes com TAs. Independentemente da modalidade psicoterápica utilizada, enfatiza-se a importância de que os profissionais da Psicologia acreditem na possibilidade de transformação operada ou coadjuvada pela psicoterapia. Acredita-se que a psicoterapia deve propiciar o trabalho conjunto entre psicoterapeuta e paciente na elaboração de aspectos mais profundos da personalidade - incluindo a vivência da feminilidade, sexualidade e relações familiares - que, segundo os dados analisados neste estudo, encontram-se intimamente relacionados à ocorrência e manutenção dos sintomas de TAs. Portanto, ressalta-se a importância da adoção de posturas menos patologizantes e estigmatizantes, que busquem uma compreensão das experiências dos indivíduos para além do quadro psicopatológico. 


\section{REFERÊNCIAS}

Abreu, N. \& Filho, R. C. (2004). Anorexia nervosa e bulimia nervosa: abordagem cognitivoconstrutivista de psicoterapia. Revista de Psiquiatria Clínica, 31(4), 177-183.

Aiello- Vaisberg, T. M. J. \& Machado, M. C. L. (2005). Transcionalidade e ensino de psicopatologia: Pensando “aulas práticas” com Winnicott. Passages de Paris, 1, 176-185.

Ambrósio, D. C. M. (2010). Mulheres com câncer de mama: A vivência do apoio social e familiar durante o tratamento. Dissertação de mestrado não publicada, Universidade de São Paulo, Ribeirão Preto, SP.

American Psychiatric Association (2013). DSM-V - Diagnostic and Statistical Manual of Mental Disorders. Recuperado em 11 de junho de 2013, de http://www.dsm5.org/ Documents/Eating\%20Disorders\%20Fact\%20Sheet.pdf.

André, J. (2001). Feminilidade adolescente. In M. R. Cardoso (Org.). Adolescência: Reflexões psicanalíticas (p. 29-39). Rio de Janeiro, RJ: NAU, FAPERJ.

André, S. (1998). O que quer uma mulher? Rio de Janeiro: Jorge Zahar.

Ávila, L. A. (1996). Doenças do corpo e doenças da alma. São Paulo, SP: Escuta.

Associação Americana de Psiquiatria. (2003). DSM-IV-TR ${ }^{T M}$ - Manual diagnóstico e estatístico de transtornos mentais: Texto revisado (4. ed. rev., C. O. Dornelles, Trad.). Porto

Alegre, RS: Artmed.Associação Brasileira de Empresas de Pesquisas (2015). Critério Brasil 2015: Base PNAD 2013. Recuperado em 6 de maio, 2016. Disponível em: http://www.abep.org/criterio-brasil.

Azevedo, L. J. C., Fères-Carneiro, T., \& Lins, S. L. B. (2015). A família e a transmissão psíquica. Psicanálise \& Barroco, 13(1), 57-71.

Back, E. A. (2011). Effects of Parental Relations and Upbringing in Troubled Adolescent Eating Behaviors, Eating Disorders: Eating disorders: The Journal of Treatment \& Prevention, 19 (5), 403-424.

Badinter, E. (1985). Um amor conquistado: O mito do amor materno (W. Dutra, Trad.) Rio de Janeiro: Nova Fronteira. 
Baptista, S. M. S. (1995). Maternidade e profissão: Oportunidades de desenvolvimento. São Paulo: Casa do psicólogo.

Behar, R., Barrera, M., \& Michelotti, J. (2003). Características clínicas e identidad genérica en subtipos de trastornos de la conducta alimentaria. Revista Médica do Chile, 131(7), 748-758.

Beltrame, G. R. \& Bottoli, C. (2010). Retratos do envolvimento paterno na atualidade. Barbarói, 32, 205-225.

Berlinck, M. T. (2002). Considerações sobre a formulação de um projeto de pesquisa em psicanálise. In Berlinck, M. T. (Org.). Psicopatologia Fundamental. São Paulo: Escuta. Recuperado em 10 novembro 2010, do http://www.uff.br/labpsifundamental/ biblioteca_biblio.htm

Bernstein, D. (1998). Angústias genitais femininas, conflitos e modos típicos de domínio (F. Náufel, M. P. Ferreira \& T. Penido Trads.). In D. Breen (Org.). O enigma dos sexos: perspectivas psicanalíticas contemporâneas da feminilidade e da masculinidade (p. 195217). Rio de Janeiro: Imago.

Birksted-Breen, D. (2005). Representação inconsciente da feminilidade. In Sociedade Psicanalítica de Porto Alegre (Org.), Psicanálise e sexualidade: Tributo ao centenário de Três Ensaios Sobre uma Teoria da Sexualidade 1905-2005 (p. 141-157). São Paulo: Casa do Psicólogo.

Birman, J. (1999). Cartografias do feminino. São Paulo: Editora 34.

Birman, J. (2006). Genealogia do feminino e da paternidade em psicanálise. Natureza Humana, 8(1), 163-180.

Bleger, J. (1971). Cuestiones metodológicas del psicoanálisis. In D. Ziziensky (Ed.), Métodos de investigación em psicologia y psicopatologia (pp.113-131). Buenos Aires: Edicones Nueva Visión.

Borges, N.J.B.G., Sicchieri, J.M.F., Ribeiro, R.P.P., Marchini, J.S. \& Santos, J.E. (2006). Transtornos alimentares: quadro clínico. Revista Medicina, 39(3), 340-348.

Bouchereau, D., \& Corcos, M. (2008). The role of fathers in eating disorders. Revue du Praticien, 58(2), 150.

Brasil. Ministério da Saúde. Conselho Nacional de Saúde (2012). Resolução nº 466, de 12 de dezembro de 2012. Diário Oficial da União. Recuperado em 31 de julho 2014, de http://conselho.saude.gov.br/resolucoes/2012/Reso466.pdf 
Braun V., \& Clarke, V. (2006). Using thematic analysis in psychology. Qualitative Research in Psychology, 3(2), 77-101.

Breuer, J. \& Freud, S. (1996). Estudos sobre a histeria. In S. Freud Edição standard brasileira das obras de psicológicas completas de Sigmund Freud (vol. 2, pp. 15-297). Rio de Janeiro: Imago. (Trabalho original publicado em 1893-1895).

Bruch, H. (1978). The golden cage: The enigma of anorexia nervosa. Cambridge: Harvard University Press.

Bruno, C. A. N. B. (2011). Anorexia: Um ponto de vista freudiano. In C. A. N. B. Bruno (Org.), Distúrbios alimentares: Uma contribuição da psicanálise (p. 49-60). Rio de Janeiro: Imago.

Brusset, B. (2003). Introdução geral. In B. Brusset, C. Couvreur, \& A. Fine (Orgs.), A bulimia (p. 7-13). São Paulo: Escuta.

Cambuí, H. A. (2013). Sofrimento psíquico contemporâneo: Um estudo psicanalítico do imaginário coletivo de estudantes de psicologia. Dissertação de mestrado não publicada, Universidade Estadual Paulista, Bauru, São Paulo.

Campos, L. K. S., Sampaio, A. B. R. F., Junior, C. G., Junior, R. M., Battistoni, M. M. M., \& Turato, E. R. (2012). Psychological characteristics of mothers of patients with anorexia nervosa: Implications for treatment ad prognosis. Trends in Psychiatry and Psychotherapy, 34(1), 13-18.

Capitaine, M., Rodgers, R. F., \& Chabrol, H. (2011). Unwanted sexual experiences, depressive symptoms and disordered eating among college students. Eating Behaviors, 12(1), 86-89.

Castellini, G., Lo Sauro, C., Lelli, L., Godini, L., Vignozzi, L., Rellini, A. H., Faravelli, C., Maggi, M., \& Ricca, V. (2013). Childhood sexual abuse moderates the relationship between sexual functioning and eating disorder psychopathology in anorexia nervosa and bulimia nervosa: A 1-year follow-up study. Journal of Sexual Medicine, 10(9), 21902200 .

Cassin, S. E., \& Von Ranson, K. M. (2005). Personality and eating disorders: A decade in review. Clinical Psychology Review, 25(7), 895-916.

Cella, S., Iannaccone, M., \& Cotrufo, P. (2013). Influence of gender role orientation (masculinity versus femininity) on body satisfaction and eating attitudes in homosexuals, heterosexuals and transsexuals. Eating and Weight Disorders, 15(2), 115-124. 
Cooper, M. J., Deepak, K., Grocutt, E., \& Bailey, E. (2007). The experience of 'feeling fat' in women with anorexia nervosa, dieting and non-dieting women: An exploratory study. European Eating Disorders Review, 15(5), 366-372.

Costa, L. R. S. (2014). Relação pai-filha no contexto dos transtornos alimentares: Uma perspectiva winnicottiana. Dissertação de Mestrado, Universidade de São Paulo, Ribeirão Preto, SP.

Couvreur, C. (2003). Fontes históricas e perspectivas contemporâneas (M. Seincman Trad.). In B. Brusset, C. Couvreur, \& A. Fine (Orgs.), A bulimia (p. 15-57). São Paulo: Escuta.

Dalmolin, B. M., Lopes, S. M. B., \& Vasconcellos, M. P. C. (2002). A construção metodológica do campo: Etnografia, criatividade e sensibilidade na investigação. Saúde e Sociedade, 11(2), 19-34.

De Felice, E. M. (2006). Vivências da maternidade e suas consequências para o desenvolvimento psicológico do filho. São Paulo: Vetor.

Dunker, K. L., \& Phillipi, S. T. (2003).Hábitos e comportamentos alimentares de adolescentes com sintomas de anorexia nervosa. Revista de Nutrição,16(1), 51-60.

Durham, E. R. (1983). Família e reprodução humana. In B. Franchetto, M. L. V. C. Cavalcanti \& M. L. Heilbonr (Orgs). Perspectivas antropológicas da mulher (Vol. 3, PP. 15-43).

Eddy, K. T., Novotny, C. M., \& Westen, D. (2004). Sexuality, personality and eating disorders. Eating Disorders, 12(3), 191-208.

Elliott, J. C. (2010). Fathers, daughters, and anorexia nervosa. Perspectives in Psychiatric Care, 46 (1), 37-47.

Emidio, T. S. (2008). Diálogos entre feminilidade e maternidade: Um estudo sob o olhar da mitologia e psicanálise. Dissertação de mestrado não publicada, Universidade Estadual Paulista, Assis, SP.

Fontanella, B. J. B., Ricas, J., \& Turato, E. R. (2008). Amostragem por saturação em pesquisas qualitativas em saúde: Contribuições teóricas. Caderno de Saúde Pública, 24(1), 17-27.

Freud, S. (1976). Sobre o narcisismo: Uma introdução. In S. Freud Edição standard brasileira das obras de psicológicas completas de Sigmund Freud (vol. 14, pp. 75-108). Rio de Janeiro: Imago. (Trabalho original publicado em 1914). 
Freud, S. (1976). Conferência XXXIII: Feminilidade. In S. Freud Edição standard brasileira das obras de psicológicas completas de Sigmund Freud (vol. 22, pp. 139-165). Rio de Janeiro: Imago. (Trabalho original publicado em 1933).

Freud, S. (1972). Sexualidade feminina. In S. Freud Edição standard brasileira das obras de psicológicas completas de Sigmund Freud (vol. 21, pp. 231-251). Rio de Janeiro: Imago. (Trabalho original publicado em 1931).

Freud, S. (1996). Esboço de psicanálise. In S. Freud Edição standard brasileira das obras psicológicas completas de Sigmund Freud (J. Salomão, Trad.). Rio de Janeiro: Imago. (Obra original publicada em 1938).

Fulgêncio, C. D. R. (2007). A presença do pai no processo de amadurecimento: um estudo sobre D. W. Winnicott. Tese de Mestrado, Pontifícia Universidade Católica de São Paulo, São Paulo.

Gaspar, F. L. (2010). Anorexia e violência psíquica. Curitiba, PR: Juruá.

Ghizzani, A. \& Montomoli, M. (2002). Anorexia nervosa and sexuality in women: A review. Journal of Sex Education and Therapy, 25(1), 80-88.

Gomes, A. J. S. \& Resende, V. R. (2004). O pai presente: o desvelar da paternidade em uma família contemporânea. Psicologia: Teoria e Pesquisa, 20(2), 1-14.

Gorgati, S. B. (2002). O feminino congelado na anorexia. In S. L. Alonso, A. C. Gurfinkel, \& D. M. Breyton (Orgs.), Figuras clínicas do feminino no mal-estar contemporâneo (pp. 115-128). São Paulo: Escuta.

Green, M. A., Davids, C. M., Skaggs, A. K., Riopel, C. M., \& Hallengren, J. J. (2008). Femininity and eating disorders. Eating Disorders, 16(4), 283-293.

Halberstadt-Freud, H. C. (2001). Electra cativa: Sobre a simbiose e a ilusão simbiótica entre mãe e filha e as consequências para o complexo de Édipo. Revista Brasileira de Psicanálise, 35(1), 143-168.

Heenan, C. (2005). A feminist psychotherapeutic approach to working with women who eat compulsively. Counselling and Psychotherapy Research, 5(3), 238-245.

Hepp, U., Spindler, A., \& Milos, G. (2005). Eating disorder symptomatology and gender role orientation. International Journal of Eating Disorders, 37(3), 227-233. 
Holovko, C. S. (2008). Editorial a convite: O feminino. Revista Brasileira de Psicanálise, 42(4), 13-14.

Hooper, A., \& Dallos, R. (2012). Fathers and daughters: Their relationship and attachment themes in the shadow of aneating disorder. Contemporary Family Therapy. 34 (4) 452467.

Hoskins, M. L. (2002). Girl's identity dilemas: Spaces defined by definitions of worth. Health Care for Women International, 23(3), 231-247.

Iaconelli, V. (2014). Algumas questões do feminino e da histeria encenadas em um caso de hiperêmese gravídica. In P. E. S. Ambra \& N. Silva Jr. (Orgs.) Histeria e gênero: Sexo como desencontro (p. 197). São Paulo: nVersos.

Iribarry, I. N. (2003). O que é pesquisa psicanalítica? Ágora, 6(1), 115-138.

Januário, L. M. \& Tafuri, M. I. (2011). A relação transferencial para além da interpretação: Reflexões a partir da teoria de Winnicott. Ágora (Rio de Janeiro), 14(2), 259-274.

Januszek, K. (2007). Some aspects of sexual identity of girls suffering from anorexia nervosa. Archives of Psychiatry and Psychotherapy, 9(3), 53-62.

Jones, A., Evans, M., Bamford, B., \& Ford, H. (2008). Exploring quality of life for eating disordered patients. European Eating Disorders Review, 16(4), 276-286.

Jones, C. J., Leung, N., \& Harris, G. (2006). Father-daughter relationship and eating psychopatology: The mediating role of core beliefs. British Journal of Clinical Psychology, 45, 319-330.

Jones C. J., Harris, G. \& Leung, N. (2005). Parental rearing behaviours and eating disorders: the moderating role of core beliefs. Eating Behaviors, 6(4), 355-364.

Kaltiala-Heino, R., Rimpelä, M., Rissanen, A., \& Rantanen, P. (2001). Early puberty and early sexual activity are associated with bulimic-type eating pathology in middle adolescence. Journal of Adolescent Health, 28(4), 346-352.

Kaye, W. (2008). Neurobiology of anorexia and bulimia nervosa. Physiology \& Behavior, 94(1), 121-135.

Kehl, M. R. (2008). Deslocamentos do feminino (2a ed.). Rio de Janeiro: Imago. 
Klein, M. (1945). The Oedipus Complex in the light of early anxieties. International Journal of Psychoanalysis, 26, 11-33.

Klein, M. (1981). Contribuições à psicanálise (M. Maillet, Trad.) São Paulo: Mestre Jou. (Original publicado em 1934).

Lacan, J. (1958). A significação do falo. In J. Lacan Escritos (p. 692). Rio de Janeiro: Jorge Zahar Editores.

Lam, C. B., \& McHale S. M. (2012). Developmental Patterns and Family Predictors of Adolescent Weight Concerns: A Replication and Extension. International Journal of Eating Disorders, 45 (4), 524 - 530.

Lane, R. C. (2002). Anorexia, masochism, self-mutilation, and autoerotism: The spider mother. Psychoanalitic Review, 89(1), 101-123.

Latzer, Y., Hochdorf, Z., Bachar, E., \& Canetti, L. (2002). Attachment style and family functioning as discriminating factors in eating disorders. Contemporary Family Therapy: An International Journal, 24(4), 581-599.

Lawrence, M. (1991). A experiência anoréxica (T. M. Rodrigues, Trad.). São Paulo: Summus.

Leonidas, C. \& Santos, M. A. (2010). Avaliação da imagem corporal e das atitudes alimentares de pacientes com anorexia nervosa. In E. J. R. Santos (Org.), Aconselhamento na saúde: Perspectivas integradoras (p. 261-277). Coimbra: PsicoSoma.

Leonidas, C. \& Santos, M. A. (2011). Redes sociais de pacientes com transtornos alimentares: Um estudo de casos múltiplos. Anais do II Congresso Luso-Brasileiro de Psicologia da Saúde e I Congresso Ibero-Americano de Psicologia da Saúde. São Bernardo do Campo, SP, Brasil, [CD-ROM].

Leonidas, C. \& Santos, M. A. (2012). Vivências afetivo-familiares de mulheres com transtornos alimentares. Anais do II Congresso Internacional de Sexualidade e Educação Sexual "Pesquisas, Intervenções e Direitos”, Araraquara, SP, Brasil, [CD-ROM].

Leonidas, C. \& Santos, M. A. (2012). Imagem corporal e hábitos alimentares na anorexia nervosa: Uma revisão integrativa da literatura. Psicologia: Reflexão e Crítica, 23(3), 550558.

Leonidas, C. \& Santos, M. A. (2013). Instrumentos de avaliação da imagem corporal e dos hábitos alimentares na anorexia nervosa: Análise da produção científica. Psicologia: Ciência e Profissão, 33(4), 868-883. 
Leonidas, C. \& Santos, M. A. (2013). Redes sociais significativas de mulheres com transtornos alimentares. Psicologia: Reflexão e Crítica, 26(3), 561-571.

Leonidas, C. \& Santos, M. A. (2014). Social support networks and eating disorders: An integrative review of the literature. Neuropsychiatric Disease and Treatment, 10, 915927.

Leonidas, C. \& Santos, M. A. (2015a). Relacionamentos afetivo-familiares em mulheres com anorexia e bulimia. Psicologia: Teoria e Pesquisa, 31(2), 181-191.

Leonidas, C. \& Santos, M. A. (2015b). Family relations in eating disorders: The Genogram as instrument of assessment. Ciência \& Saúde Coletiva,20(5), 1435-1447.

Leonidas, C., Santos, M. A., \& Noce, M. A. (2008). Imagem corporal de pacientes com anorexia nervosa avaliada pelo desenho da figura humana. Anais do $V$ Encontro da Associação Brasileira de Rorschach e Métodos Projetivos (ASBRo), Ribeirão Preto, SP, Brasil, [CD-ROM].

Leonidas, C., Santos, M. A., \& Noce, M. A. (2008). Anorexia nervosa: Imagem corporal e atitudes alimentares avaliadas através do BSQ e do EAT-26. Anais do V Encontro da Associação Brasileira de Rorschach e Métodos Projetivos (ASBRo), Ribeirão Preto, SP, Brasil, [CD-ROM].

Leonidas, C., Santos, M. A., \& Noce, M. A. (2008). Avaliação quantitativa da imagem corporal e das atitudes alimentares de pacientes com anorexia nervosa. Anais XIII Conferência Internacional - Avaliação Psicológica: Formas e Contextos, Braga, Portugal, [CD-ROM].

Leonidas, C., Crepaldi, M. A., \& Santos, M. A. (2013). Bulimia nervosa: Uma articulação entre aspectos emocionais e rede de apoio social. Psicologia: Teoria e Prática, 15(2), 6275.

Limbert, C. (2010). Perceptions of social support and eating disorder characteristics. Health Care for Women International, 31(2), 170-187.

Lisboa, A. V., \& Fères-Carneiro, T. (2015). Acontecimentos significativos na história geracional e sua relação com somatizações na família. Psicologia: Teoria e Pesquisa, 31(1), 65-72.

Mahalik, J. R., Morray, E. B., Coonerty-Femiano, A., Ludlow, L. H., Slattery, S. M., \& Smiler, A. (2005). Development of the Conformity to Feminine Norms Inventory. Sex Roles, 52(7-8), 417-435. 
Mandelbaum, B. (2012). Família incestuais. Psicologia Clínica, Rio de Janeiro, 24 (11), 55 66.

Matthews-Ewald, M. R., Zullig, A. J., \& Ward, R. M. (2014). Sexual orientation and disordered eating among self identified male and female college students. Eating Behaviours, 15, 441-444.

Matsumoto, D. G. (2009). Maternidade e transtornos alimentares: A ótica de mulheres com anorexia e bulimia nervosa. Monografia de Conclusão de Curso não publicada, Universidade de São Paulo, Ribeirão Preto, SP.

Maykut, P., \& Morehouse, R. (1994). Beggining qualitative research: A philosophic and practical guide. Londres: Farmer Press Teacher's Library.

McDougall, J. (1989). Teatros do eu (O. Coddá, Trad.). Rio de Janeiro: Francisco Alves.

McDougall, J. (1991). Teatros do corpo (P. H. B. Rondon, Trad.). São Paulo: Martins Fontes.

McDougall, J. (1997). As múltiplas faces de eros: Uma exploração psicoanalítica da sexualidade humana (P. H. B. Rondon, Trad.). São Paulo: Martins Fontes.

Meira, B. B. A. (2005). Psicodinâmica familiar das mães acompanhantes de bebês prematuros à luz das contribuições psicanalíticas. Dissertação de mestrado não publicada, Universidade Estadual Paulista “Julio de Mesquita Filho”, Assis, SP.

Meyer, C., Blisset, J., \& Oldfield, C. (2001). Sexual orientation and eating psychopathology: The role of masculinity and femininity. International Journal of Eating Disorders, 29(3), 314-318.

Mezan, R. (1998). Tempo de muda: Ensaios de psicanálise. São Paulo: Companhia das Letras.

Michie, S., Ashford, S., Sniehotta, F. F., Dombrowski, S. U., Bishop, A., \& French, D. P. (2011). A refined taxonomy of behaviour change techniques to help people change their physical activity and healthy eating behaviours: The CALO-RE taxonomy. Psychology and Health, 26(11), 1479-1498.

Minayo, M.C.S. (2008). O desafio do conhecimento científico: Pesquisa qualitativa em saúde. $11^{\mathrm{a}}$ ed. São Paulo/Rio de Janeiro: Hucitec.

Miranda, M. R. (2007). Em busca das palavras perdidas: Corpo-carcereiro da mente nos distúrbios alimentares. Ide, 30(45), 28-34. 
Miranda, M. R. (2011). A complexidade da relação mãe-filha nas patologias dos contrários. In C. A. N. B. Bruno (Org.), Distúrbios alimentares: Uma contribuição da psicanálise (p. 123-154). Rio de Janeiro: Imago.

Moore, F. \& Keel, P. K. (2003). Influence of sexual orientation and age on disordered eating attitudes and behaviors in women. International Journal of Eating Disorders, 34(3), 370374.

Morgan, C. M., Vecchiatti, I. R. \& Negrão, A. B. (2002). Etiologia dos transtornos alimentares: aspectos biológicos, psicológicos e sócio-culturais. Revista Brasileira de Psiquiatria, 24(3), 18-23.

Nilsson, K., Sundbom, E., \& Häglöf, B. (2008). A longitudinal study of perfectionism in adolescent onset anorexia nervosa, restricting type. European Eating Disorders Review, 16(5), 386-394.

Neri, R. (2005). A psicanálise e o feminino: Um horizonte da modernidade. Rio de Janeiro: Civilização Brasileira.

Nodin, N., \& Leal, I. P. (2005) Representações paternas na anorexia nervosa. Análise Psicológica, 23(2), 201-208.

Oliveira, E. A. \& Santos, M. A. (2006). Perfil psicológico de pacientes com anorexia e bulimia nervosas: a ótica do psicodiagnóstico. Revista Medicina, 39(3), 353-360.

Oliveira, N. R. \& Tafuri, M. I. (2012). O método psicanalítico de pesquisa e a clínica: Reflexões no contexto da Universidade. Revista Latinoamericana de Psicopatologia Fundamental, 15(4), 838-850.

Paccola, A. T. F. (2006). Escuta do psiquiatra: Sinais e sintomas de anorexia nervosa e bulimia nervosa. Medicina (Ribeirão Preto), 39(3), 349-352.

Pec, O., Bob, P., \& Raboch, J. (2014). Dissociation in schizophrenia and borderline personality disorder. Neuropsychiatric Disease and Treatment, 10, 487-491.

Peres, R. S. (2006). O corpo na psicanálise contemporânea: Sobre as concepções psicossomáticas de Pierre Marty e Joyce McDougall. Psicologia Clínica, 18(1), 165-177.

Peres, R. S., \& Santos, M. A. (2006). Contribuições do Desenho da Figura Humana para a avaliação da imagem corporal na anorexia nervosa. Medicina (Ribeirão Preto), 39(3), 361-370. 
Pinheiro, A. P., Raney, T. J., Thornton, L. M., Fichter, M. M., Berretini, W. H., Goldman, D., Halmi, K. A., Kaplan, A. S., Strober, M., Treasure, J., Woodside, D. B., Kaye, W. H., \& Bulik, C. M. (2010). Sexual functioning in women with eating disorders. International Journal of Eating Disorders, 43(2), 123-129.

Polit, D. F., Beck, C. T., \& Hungler, B. P. (2004). Fundamentos de pesquisa em enfermagem: Métodos, avaliação e utilização (A. Thorell, Trad.). $5^{\mathrm{a}}$ ed. Porto Alegre: Artmed.

Ribeiro, M. (2011). De mãe em filha: A transmissão da feminilidade. São Paulo: Escuta.

Rodríguez, M. B., Hernández, A. P., \& Bouly, R. P. (2007). Anorexia nerviosa: Características y síntomas. Revista Cubana de Pediatria, 72(4), 300-305.

Romejko-Borowiec, A. (2004). Eating disorders as a specific method of solving the sexual identity crisis. Archives of Psychiatry and Psychotherapy, 6(4), 41-48.

Rosa, M. D. \& Domingues, E. (2010). O método na pesquisa psicanalítica de fenômenos sociais e políticos: A utilização da entrevista e da observação. Psicologia \& Sociedade, 22(1), 180-188.

Rosa, B. P., \& Santos, M. A. (2011). Comorbidade entre bulimia e transtorno de personalidade borderline: Implicações para o tratamento. Revista Latinoamericana de Psicopatologia Fundamental, 14(2), 268-282.

Ruuska, J., Kaltiala-Heino, R., Koivisto, A. M., \& Rantanen, P. (2003). Puberty, sexual development and eating disorders in adolescent outpatients. European Child \& Adolescent Psychiatry, 12(5), 214-220.

Safra, G. (2013). Investigação em psicanálise fora do consultório: Princípios metodológicos. In C. A. Serralha \& F. Scorsolini-Comin (Orgs.), Psicanálise e universidade: Um encontro na pesquisa ( $1^{\mathrm{a}}$ ed.). Curitiba: CRV.

Silva, D. Q. (2013). A pesquisa em psicanálise: O método de construção do caso psicanalítico. Estudos de Psicanálise, 39, 37-46.

Simoni, J. M. \& Bastos, A. (2013). Quando a anorexia é uma questão de sexuação. Arquivos Brasileiros de Psicologia, 65(3), 409-420.

Smink, F. R. E., Hoeken, D. V., \& Hoek, H. W. (2013). Epidemiology, course and outcome of eating disorders. Current Opinion, 26(6), 543-548. 
Soifer, R. (1980). Psicologia da gravidez, parto e puerpério. Porto Alegre: Artes Médicas.

Stake, R. E. (2000). Case studies. In N. Denzin \& Y. Lincoln (Eds.) Handbook of qualitative research (pp. 236-247). $2^{\mathrm{a}}$ ed. California: Sage Publications.

Tong, A., Sainsbury, P., \& Craig, J. (2007). Consolidated criteria for reporting qualitative research (COREQ): A 32-item checklist for interviews and focus groups. International Journal of Quality of Health Care, 19(6), 349-357.

Valdanha, E. D., Scorsolini-Comin, F., \& Santos, M. A. (2013). Anorexia nervosa e transmissão psíquica transgeracional. Revista Latinoamericana de Psicopatologia Fundamental, 16(1), 71-88.

Vieira, G. T. \& Nascimento, A. R. A. (2014). Aspectos psicossociais da construção da identidade paterna. Revista Psicologia: Teoria e Prática, 16(1), 57-68.

Vindreau, C. (2003). A bulimia na clínica psiquiátrica. In B. Brusset, C. Couvreur, \& A. Fine (Orgs.), A bulimia (p. 81-102). São Paulo: Escuta.

Weber, F. (2009). A entrevista, a pesquisa e o íntimo, ou por que censurar seu diário de campo? Horizontes Antropológicos, 15(32), 157-170.

Weeks, J. (2009). The remaking of erotic and intimate life. Política y Sociedad, 46(1), 13-25.

Wiederman, M. W., Pryor, T., \& Morgan, C. D. (1996). The sexual experience of women diagnosed with anorexia nervosa or bulimia nervosa. International Journal of Eating Disorders, 19(2), 109-118.

Winnicott, D. W. (1994). O uso de um objeto no contexto de Moisés e o monoteísmo. In: C. Winnicott, R. Shepherd \& M. Davis. Explorações psicanalíticas: D.W. Winnicott. (J. O. A. Abreu, trad., pp. 187-191). Porto Alegre: Artes Médicas. (Trabalho original publicado em 1969).

Winnicott, D. W. (2000). Desenvolvimento emocional primitivo. In: D. W. Winnicott, Textos selecionados: Da pediatria à psicanálise. (D. Bogomoletz, trad.) (2a ed.). Rio Janeiro: Imago. (Trabalho original publicado em 1945)

Woolhouse, M., Day, K., Rickett, B., \& Milnes, K. (2012). “Cos girls aren't supposed to eat like pigs are they?” Young women negotiating gendered discursive constructions of food and eating. Journal of Health Psychology, 17(1), 46-56.

Zimerman, D. E. (1999). Fundamentos psicanalíticos: teoria, técnica e clínica - uma abordagem didática. Porto Alegre: Artes Médicas. 


\section{ANEXOS}

\section{Anexo I. Revisão integrativa}

Este estudo teve por objetivo sintetizar a produção científica nacional e internacional acerca da sexualidade e feminilidade nos transtornos alimentares (TAs). Buscou-se evidenciar os artigos indexados em periódicos científicos, com uma apreciação crítica da qualidade metodológica dos estudos, de modo a identificar as tendências apontadas por essas publicações, seus limites e possibilidades, favorecendo a identificação de convergências e lacunas acerca do tema em questão.

\section{Método}

A revisão integrativa da literatura foi o método de pesquisa privilegiado. Tal método é reconhecido por permitir a análise e síntese dos resultados de várias pesquisas que abordam o mesmo tema, utilizando-se assim de dados secundários que possibilitam aprofundamento em determinado campo do conhecimento, favorecendo a elaboração de conclusões e generalizações (Broome, 2000; Leonidas \& Santos, 2014; Pai et al., 2004). Segundo Whittemore e Knafl (2005), a revisão integrativa, como método de pesquisa, permite sintetizar a literatura referente a condições clínicas específicas ou a determinados fenômenos de interesse, incorporando múltiplas perspectivas e combinando dados resultantes de estudos tanto teóricos quanto empíricos, e com diversos delineamentos metodológicos, qualitativos e quantitativos.

A estratégia de revisão integrativa envolveu, de maneira geral, os seguintes passos (Leonidas \& Santos, 2014; Machado, Leonidas, \& Santos, 2012): (1) levantamento sistemático de publicações nacionais e internacionais acerca do tema dos TAs, feminilidade e sexualidade; (2) identificação dos autores, delineamento metodológico de cada estudo, ano e periódico de publicação, país de origem, língua na qual foram escritos, objetivos dos estudos e resultados obtidos; e (3) realização de análise descritiva dos resultados dos estudos selecionados e avaliação crítica das contribuições oferecidas pela literatura científica disponível acerca do tema em questão.

As bases de dados consultadas foram: PubMed, CINAHL, PsycINFO e LILACS. As três primeiras são bases internacionais consagradas à indexação de estudos da área de Medicina, Enfermagem e Psicologia, respectivamente, e a última é uma base genérica que colige a produção científica dos países latino-americanos e do Caribe. De forma mais 
detalhada, tem-se que a PubMed é uma base de dados internacional da área médica e biomédica, produzida pela NLM (National Library of Medicine). Contém referências de artigos que cobrem as áreas de: medicina, biomedicina, enfermagem, odontologia, veterinária e ciências afins. CINAHL (Cumulative Index to Nursing and Allied Health Literature) é uma das bases de dados mais utilizadas dentre aquelas englobadas pelo EBSCOhost Online Research Databases. Compreende vasta literatura da área de enfermagem e saúde em geral. PsycINFO é uma base de dados que abrange artigos com temas relacionados à psicologia, educação, psiquiatria e ciências sociais. Dispõe de publicações veiculadas em periódicos internacionais e contém aproximadamente 1.500.000 registros. Por fim, LILACS é uma base de dados cooperativa da Rede BVS, que compreende a literatura relativa às ciências da saúde, publicada nos países da América Latina e Caribe, a partir de 1982. Atinge mais de 400.000 mil registros e contém artigos de cerca de 1.300 revistas conceituadas da área da saúde, das quais aproximadamente 730 continuam sendo atualmente indexadas; também abarca outros documentos, tais como: teses, capítulos de teses, livros, capítulos de livros, anais de congressos ou conferências, relatórios técnico-científicos e publicações governamentais.

Desse modo, foram selecionadas para o presente estudo duas bases de dados internacionais, que são consideradas referências na literatura em saúde (PubMed e CINAHL); uma base, também de abrangência internacional, que incorpora trabalhos específicos da área da Psicologia (PsycINFO) e uma base que inclui os trabalhos publicados na América Latina e do Caribe (LILACS).

A questão de pesquisa que norteou esta revisão foi baseada na estratégia PICO Participants, Interventions, Comparisons and Outcomes (Akobeng, 2005; Santos, Pimenta, \& Nobre, 2007; Stillwell, Fineout-Overholt, Melnyk, \& Williamson, 2010) e foi assim formulada: "De que maneira a sexualidade e a feminilidade se articulam com o desenvolvimento e manutenção dos sintomas de TAs?”. Participants: foram incluídos estudos com mulheres com diagnóstico de TAs ou que faziam parte de populações de risco para a ocorrência desses quadros, ainda que não tivessem diagnóstico preestabelecido. Também foram incluídos estudos com homens heterossexuais e homossexuais, desde que tivessem como objetivo comparar a sexualidade entre homens e mulheres (Comparisons), uma vez que o objeto desta pesquisa é a sexualidade feminina no contexto dos TAs. Interventions: não houve restrição de estudos em função do método e delineamento de pesquisa. Outcomes: foram incluídos estudos que oferecessem evidências significativas no que diz respeito à vivência da sexualidade feminina, relacionando-a com aspectos emocionais da personalidade e psicopatologias alimentares. 
A busca nas bases indexadoras foi realizada em julho de 2014 e complementada em janeiro de 2015. Para operacionalizar a revisão integrativa foram selecionados os seguintes descritores, segundo o DeCS - Descritores em Ciências da Saúde: eating disorders, femininity, sexuality, sexual behavior. Considerando-se que as buscas com os descritores em português resultavam em menor número de artigos encontrados, e que todos os artigos capturados com os descritores em português também eram encontrados com os descritores em inglês, optou-se por utilizar apenas os descritores na língua inglesa. Além disso, tendo em vista que o objetivo de busca bibliográfica era localizar artigos que apresentassem uma intersecção entre os temas propostos, as buscas nas bases de dados foram realizadas utilizando os operador booleano and, e os descritores de maneira combinada: eating disorders and femininity, eating disorders and sexuality, eating disorders and sexual behavior, eating disorders and femininity and sexuality, eating disorders and femininity and sexual behavior. Após o levantamento das publicações, os resumos foram lidos e analisados segundo os critérios de inclusão/exclusão preestabelecidos, que serão descritos na sequência.

Nesta revisão foram incluídas publicações que tematizam a sexualidade e a feminilidade no contexto dos TAs. Foram excluídas produções científicas não publicadas em formato de artigos, tais como dissertações, teses, livros, capítulos e resenhas de livros, resumos e trabalhos publicados em anais de eventos científicos, relatórios, cartas e editoriais. Essa escolha se deve ao fato de que, em duas das bases utilizadas (LILACS e PsycINFO), notou-se o registro dessas modalidades de trabalhos e, não obstante as teses e dissertações terem sido submetidas à avaliação pelos Programas de Pós-graduação nos quais foram produzidas, o método utilizado para a elaboração da revisão preconiza que essas produções devem ser suprimidas, uma vez que se objetiva selecionar apenas as publicações que foram submetidas ao crivo crítico de um procedimento rigoroso de avaliação por pares às cegas. Entende-se que a revisão por pares e o rigor da Comissão Editorial dos periódicos é um diferencial na preservação da qualidade do artigo e de sua apreciação científica. Desse modo, a busca foi circunscrita aos trabalhos submetidos a processo rigoroso de avaliação, sendo selecionados exclusivamente artigos indexados.

Foram excluídos ainda: estudos que abordavam problemas da conduta alimentar secundários a outras doenças, tais como: obesidade, diabetes mellitus, síndrome do ovário policístico, entre outros; validação de testes e outros instrumentos padronizados para países que não o Brasil; estudos vinculados fortemente à área médica (por exemplo, ginecologia adolescente), com temáticas muito distantes da Psicologia ou provenientes de outras áreas do saber que não apresentavam relação direta com a Psicologia ou com o enfoque desta 
investigação. Foram excluídos também os artigos indexados em periódicos que não estavam disponíveis na íntegra por meio do acesso online franqueado pela RedeUSP.

Em relação ao período de publicação, foram selecionados artigos datados de janeiro de 2000 e dezembro de 2014. Em relação à língua, restringiu-se a busca aos estudos publicados nos idiomas português, inglês e espanhol. Os artigos duplicados, isto é, que apareceram em mais de uma base indexadora, a partir de diferentes combinações de descritores, foram computados uma única vez.

Os artigos na íntegra foram recuperados e analisados, constituindo o corpus de análise da revisão. Esses artigos selecionados foram submetidos a uma leitura analítica, realizada de modo independente por dois pesquisadores com experiência na aplicação do procedimento. Os dados foram extraídos por meio de um formulário elaborado para essa finalidade e validado em estudo anterior (Machado, Leonidas, \& Santos, 2012). A apreciação do material envolveu a identificação das seguintes dimensões: título, ano de publicação, país de origem do estudo, população investigada/participantes, referencial teórico, objetivos, delineamento metodológico, instrumentos utilizados e principais resultados. Para assegurar a fidedignidade da classificação, os resultados que obtiveram consenso entre os dois avaliadores foram aceitos automaticamente. Já as análises que se revelaram discordantes foram discutidas caso a caso até que se chegasse a um comum acordo.

\section{Resultados e Discussão}

A busca foi iniciada pela base de dados PubMed, na qual foi encontrado um total de 250 artigos a partir dos diferentes agrupamentos dos descritores, sendo que 12 foram selecionados pela pertinência em relação aos critérios de inclusão e exclusão. A seguir procedeu-se à busca na base de dados LILACS, na qual foram encontrados 39 artigos a partir dos diferentes agrupamentos dos descritores, sendo que apenas um foi selecionado. A base de dados consultada a seguir foi o PsycINFO, no qual foram encontrados 163 artigos, sendo selecionados seis. Por fim, na CINAHL foram encontrados 29 artigos, sendo que apenas dois passaram pelo crivo de seleção. Assim, após a aplicação dos critérios de inclusão e exclusão e do descarte dos artigos repetidos em mais de uma base indexadora, 21 publicações foram selecionadas, compondo o corpus de análise. Esses dados podem ser melhor visualizados na Tabela 1. Nota-se que, do ponto de vista dos artigos encontrados, as bases que mais contribuíram com artigos relacionados à temática investigada foram a PubMed e a PsycINFO. 
Tabela 1. Distribuição dos artigos segundo as bases de dados bibliográficos consultadas

\begin{tabular}{lcccc}
\hline $\begin{array}{c}\text { Base de } \\
\text { dados }\end{array}$ & $\begin{array}{c}\text { Artigos } \\
\text { encontrados }\end{array}$ & $\mathbf{\%}$ & $\begin{array}{c}\text { Artigos } \\
\text { selecionados }\end{array}$ & $\mathbf{\%}$ \\
\hline PubMed & 268 & 52,34 & 12 & 52,17 \\
LILACS & 39 & 7,62 & 1 & 4,35 \\
PsycINFO & 174 & 33,99 & 8 & 34,78 \\
CINAHL & 31 & 6,05 & 2 & 8,69 \\
\hline Total & 512 & 100,0 & 23 & 100,0 \\
\hline
\end{tabular}

Entre os estudos excluídos em um exame preliminar, já a partir da leitura dos resumos, a maioria se referia a quadros clínicos específicos, como obesidade, diabetes mellitus e outras condições clínicas que podem desencadear perturbações do comportamento alimentar como sintomas secundários. Também foram eliminadas investigações sobre prevalência e tratamento dessas doenças, bem como estudos dedicados ao desenvolvimento e validação de testes e escalas. Outros eixos de investigação excluídos foram: estudos publicados em idiomas distintos daqueles preestabelecidos nos critérios de inclusão, tais como italiano, turco e alemão; assistência à saúde da população LGBTT; efeito das mídias eletrônicas sobre a conduta alimentar de crianças; comportamentos psicossociais de risco em populações específicas não clínicas. Deve-se destacar que tais estudos não poderiam contribuir para a discussão almejada, uma vez que os temas abordados estão muito distantes do foco delimitado.

Os passos metodológicos da presente revisão, assim como o número de artigos excluídos a partir de cada critério aplicado, podem ser melhor visualizados na Figura 1. 
$1^{\circ}$ Passo: Realização das buscas nas bases de dados com as cinco combinações de descritores

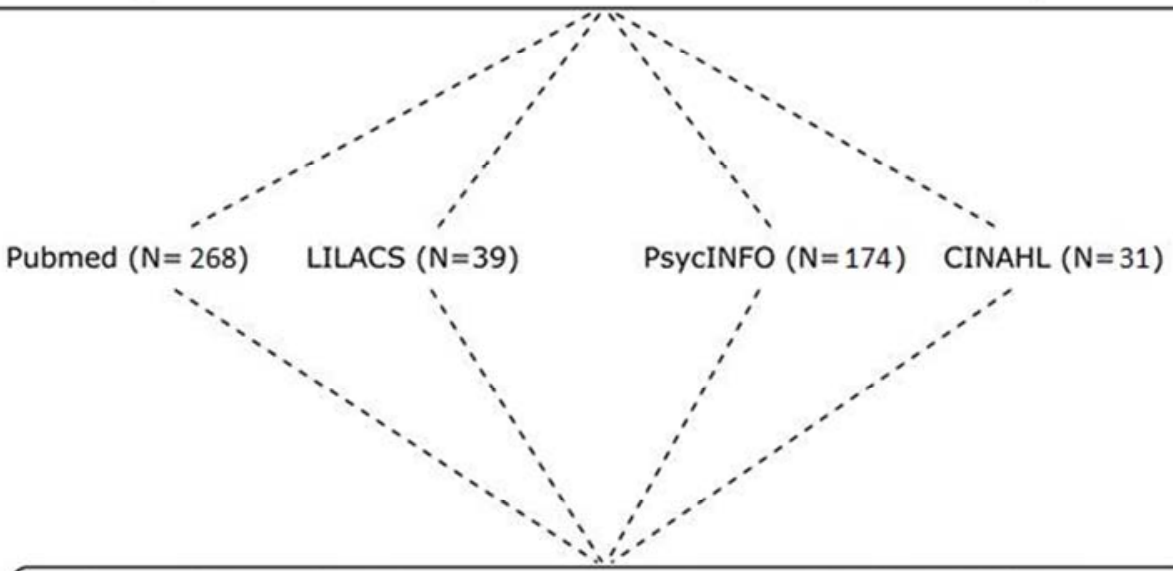

$2^{\circ}$ Passo: Verificação do que se repete entre o material coletado $(N=512)$

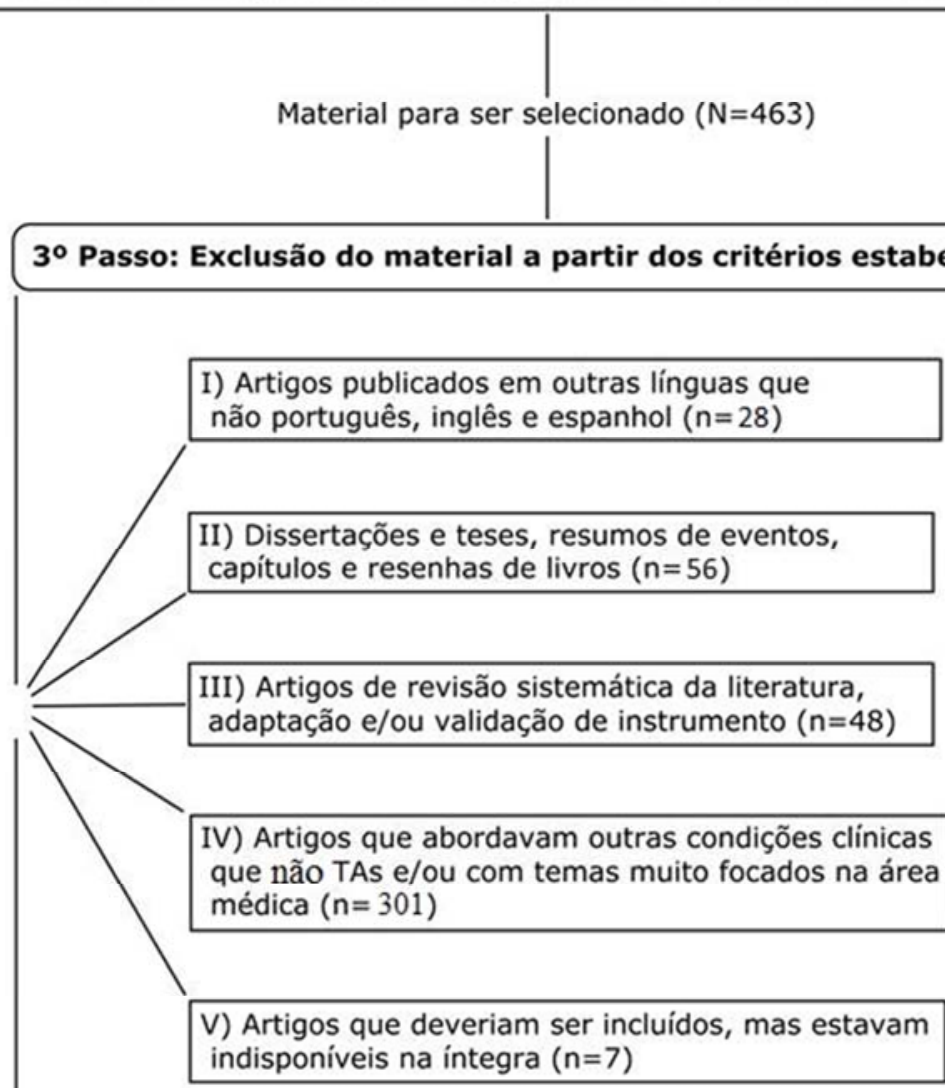

Artigos para análise na presente revisão integrativa de literatura $(\mathrm{N}=23)$

Figura 1. Fluxograma dos passos metodológicos da revisão integrativa da literatura, baseado no modelo proposto por Veit e Castro (2013). 
De acordo com a Tabela 2, o ano de 2013 concentrou o maior número de artigos selecionados. Pode-se considerar que o número restrito de publicações desde o ano de 2000 indica que mais investigações científicas nesse campo do conhecimento ainda se fazem necessárias.

Tabela 2. Distribuição dos artigos selecionados segundo o ano de publicação

\begin{tabular}{cc}
\hline Ano de publicação & $\begin{array}{c}\text { Número de artigos } \\
\text { selecionados }\end{array}$ \\
\hline 2000 & 1 \\
2001 & 2 \\
2002 & 2 \\
2003 & 3 \\
2004 & 2 \\
2005 & 2 \\
2006 & - \\
2007 & 1 \\
2008 & 1 \\
2009 & - \\
2010 & 1 \\
2011 & 1 \\
2012 & 1 \\
2013 & 4 \\
2014 & 2 \\
\hline Total & 21 \\
\hline
\end{tabular}

No que se refere ao local de publicação, definido pelo país do primeiro autor do artigo, a maior parcela dos artigos é oriunda dos Estados Unidos $(n=6)$, Reino Unido (n=3) e Itália $(n=3)$, seguidos de dois estudos poloneses e dois finlandeses. Brasil, Chile, Suíça, França e Canadá são países de origem de uma publicação selecionada.

É possível visualizar, por meio da Tabela 3, a caracterização dos artigos recuperados. O delineamento dos estudos foi definido com base nos critérios propostos por Sousa, Driessnack e Mendes (2007). A maior parte corresponde a estudos empíricos não experimentais, descritivos e correlacionais $(n=10)$ e estudos exploratórios e descritivos $(n=$ 6). Também foram identificados estudos quase experimentais $(n=4)$, não experimentais e correlacionais $(n=2)$ e apenas um estudo quase experimental e longitudinal, e outro com delineamento não experimental, prospectivo e correlacional. Não foram encontrados estudos com delineamento experimental.

Buscando classificar os estudos selecionados segundo a hierarquia das evidências (Galvão, Sawada, \& Mendes, 2003), os mesmos foram caracterizados segundo os níveis de 
evidência (NE) propostos pela Agency for Healthcare Research and Quality (AHRQ), a saber: NE 1 - metanálise de múltiplos estudos controlados; NE 2 - estudos com delineamento experimental; NE 3 - estudos quase experimentais, incluindo pré e pós-teste, longitudinais e/ou caso-controle; NE 4 - estudos com enfoque qualitativo ou com delineamentos nãoexperimentais, incluindo descritivos e correlacionais; NE 5 - relatórios de casos ou avaliações de programas; e, por fim, NE 6 - opiniões de autoridades respeitadas na área ou de especialistas, incluindo informações não fundamentadas em pesquisas (Hughes, 2008). De acordo com a categorização descrita pela AHRQ, os estudos da presente revisão foram classificados em: NE $4(n=16)$ e NE $3(n=5)$. Não foram encontrados estudos com níveis de evidência mais robustos, que corresponderiam a NE 1 e 2 . 
Tabela 4. Caracterização dos artigos recuperados segundo título, população estudada, delineamento do estudo, NE, objetivos, instrumentos e principais resultados $(n=21)$

\begin{tabular}{|c|c|c|c|c|c|}
\hline $\begin{array}{l}\text { Autores e ano } \\
\text { de publicação }\end{array}$ & $\begin{array}{l}\text { População } \\
\text { estudada }\end{array}$ & $\begin{array}{l}\text { Delineamento } \\
\text { do estudo e } \\
\text { NE }\end{array}$ & Objetivos & $\begin{array}{l}\text { Instrumentos/ } \\
\text { Procedimentos }\end{array}$ & Principais resultados \\
\hline $\begin{array}{l}\text { Ghizzani \& } \\
\text { Montomoli } \\
\quad(2000)\end{array}$ & - & $\begin{array}{l}\text { Exploratório e } \\
\text { descritivo, de } \\
\text { reflexão } \\
\text { teórica (NE 4) }\end{array}$ & $\begin{array}{l}\text { Revisar a literatura científica } \\
\text { disponível acerca do tema da } \\
\text { sexualidade em mulheres com } \\
\text { AN. }\end{array}$ & - & $\begin{array}{l}\text { Pacientes com AN têm dificuldades para se expressar tanto na } \\
\text { esfera emocional quanto na sexual. Problemas relacionais } \\
\text { parecem ter origem multifatorial e são de complexidade } \\
\text { semelhante à dos TAs. Disfunções endocrinológicas, } \\
\text { neurológicas e fatores genéticos podem estar relacionados às } \\
\text { causas da AN, mas se considera que os fatores psicológicos } \\
\text { desempenham papel predominante na etiologia. Dificuldades } \\
\text { para manter relacionamentos interpessoais são parte importante } \\
\text { do distúrbio emocional generalizado, no qual o funcionamento } \\
\text { sexual inadequado e as atitudes conservadoras são apenas } \\
\text { elementos adicionais. }\end{array}$ \\
\hline $\begin{array}{l}\text { Kaltiala- } \\
\text { Heino, } \\
\text { Rimpelä, } \\
\text { Rissanen, \& } \\
\text { Rantanen } \\
\text { (2001) }\end{array}$ & $\begin{array}{c}\text { Adolescentes entre } \\
14 \text { e } 16 \text { anos (19321 } \\
\text { do sexo masculino e } \\
19196 \text { do sexo } \\
\text { feminino), de } 258 \\
\text { escolas finlandesas. }\end{array}$ & $\begin{array}{c}\text { Não } \\
\text { experimental, } \\
\text { descritivo, } \\
\text { correlacional } \\
\text { (NE 4) }\end{array}$ & $\begin{array}{l}\text { Examinar as associações entre } \\
\text { puberdade precoce, } \\
\text { desenvolvimento sexual } \\
\text { precoce e psicopatologias } \\
\text { alimentares do tipo bulímico } \\
\text { em adolescentes. }\end{array}$ & $\begin{array}{l}\text { Questionários formulados } \\
\text { pelos autores para examinar } \\
\text { comportamentos } \\
\text { relacionados à puberdade e } \\
\text { sexualidade, além de } \\
\text { verificar os sintomas } \\
\text { bulímicos segundo os } \\
\text { critérios diagnósticos do } \\
\text { DSM-IV para BN. }\end{array}$ & $\begin{array}{l}\text { Psicopatologias alimentares do tipo bulímico entre as } \\
\text { adolescentes do sexo feminino foram associadas à menarca e } \\
\text { experiências sexuais precoces. Dentre os adolescentes do sexo } \\
\text { masculino, o início das ejaculações na idade normativa foi } \\
\text { considerado um fator de proteção contra sintomas bulímicos. } \\
\text { Ou seja, os adolescentes cujas atividades ejaculatórias tiveram } \\
\text { início tanto precoce quanto tardiamente tinham maior risco de } \\
\text { sofrerem de sintomas bulímicos. }\end{array}$ \\
\hline $\begin{array}{l}\text { Meyer, } \\
\text { Blissett, \& } \\
\text { Oldfield } \\
\text { (2001) }\end{array}$ & $\begin{array}{c}100 \text { estudantes } \\
\text { universitários de } \\
\text { ambos os sexos (40 } \\
\text { homossexuais e } 60 \\
\text { heterossexuais). }\end{array}$ & $\begin{array}{c}\text { Não } \\
\text { experimental, } \\
\text { descritivo, } \\
\text { correlacional } \\
\text { (NE 4) }\end{array}$ & $\begin{array}{l}\text { Verificar a relação entre a } \\
\text { orientação sexual e } \\
\text { psicopatologias alimentares. }\end{array}$ & $\begin{array}{c}\text { Bem Sex Role Inventory } \\
\text { (BSRI) e Eating Attitudes } \\
\text { Test (EAT-26). }\end{array}$ & $\begin{array}{l}\text { Observaram-se relações entre feminilidade e altos níveis de } \\
\text { psicopatologias alimentares, enquanto que a masculinidade } \\
\text { foi relacionada a atitudes e comportamentos alimentares } \\
\text { relativamente saudáveis. No que concerne aos homens e } \\
\text { mulheres com orientação homossexual, os resultados } \\
\text { indicam um modelo no qual a feminilidade pode ser vista } \\
\text { como um fator de risco específico para a ocorrência de TAs, } \\
\text { enquanto que a masculinidade pode ser considerada um fator } \\
\text { de proteção. }\end{array}$ \\
\hline
\end{tabular}




\begin{tabular}{lcccc}
\hline $\begin{array}{c}\text { Autores e ano } \\
\text { de publicação }\end{array}$ & $\begin{array}{c}\text { População } \\
\text { estudada }\end{array}$ & $\begin{array}{c}\text { Delineamento } \\
\text { do estudo e } \\
\text { NE }\end{array}$ & Objetivos & $\begin{array}{c}\text { Instrumentos/ } \\
\text { Procedimentos }\end{array}$ \\
\hline
\end{tabular}

Exploratório e Apresentar uma visão descritivo, de psicanalítica dos TAs e sua reflexão teórica (NE 4) relação com outros problemas

de autoagressão, tais como

masoquismo e automutilação.

Segundo a psicanálise, a AN origina-se na relação infantil da criança com a mãe, que resulta em dificuldades na separação psicológica da dupla e no desenvolvimento de

\begin{tabular}{|c|c|c|}
\hline Lane (2002) & - & $\begin{array}{l}\text { reflexão } \\
\text { teórica (NE 4) }\end{array}$ \\
\hline
\end{tabular}

um self autônomo. O indivíduo passa a se autoagredir como

forma de expressar conflitos internos pela via corporal,

tanto de forma simbólica quanto como uma forma de

descarregar tensões e se autoconfortar, direcionar a dor mental para o corpo e autopurificar dos impulsos corporais ou como forma passivo-agressiva de vingar-se das figuras parentais.

Considerando-se que os TAs estão relacionados a questões centrais do desenvolvimento da identidade, faz-se necessário compreender como os símbolos, imagens e metáforas de uma

cultura se articulam na formação da identidade de

Discutir teorias que tratam da

forma como a cultura pós-

Exploratório e moderna influencia a formação

Hoskins

(2002)

descritivo, de

reflexão

teórica (NE 4)

do sexo feminino, e como essa

influência pode estar

relacionada à ocorrência dos

TAs.

adolescentes do sexo feminino. Os profissionais da saúde devem incentivar que as pacientes desenvolvam e trabalhem com metáforas de si, de forma a ressignificarem sua própria

posição em meio à enorme quantidade de mensagens contraditórias, realidades sintéticas e limites borrados típicos das sociedades contemporâneas. Em tempos pós-modernos, faz-se necessário questionar e reconsiderar certos discursos que têm sido tomados como verdades inquestionáveis, ao invés de serem vistos como meras construções sociais que podem ser revistas.

Não houve diferença estatisticamente significante entre os grupos de pacientes com $\mathrm{AN}$ e $\mathrm{BN}$ no que concerne à idade da menarca. Atitudes frente à sexualidade foram mais

Ruuska,

Kaltiala-

Heino,

Koivisto, \&

57 adolescentes do sexo feminino com

TAs, com idades

Rantanen entre 14 e 21 anos.
Não-

correlacional

(NE 4) experimental
Avaliar associações entre TAs, puberdade e atitudes frente à sexualidade.
Entrevista semiestruturada questionários autoaplicados elaborados pelos autores do estudo. 


\begin{tabular}{|c|c|c|c|c|c|}
\hline $\begin{array}{l}\text { Autores e ano } \\
\text { de publicação }\end{array}$ & $\begin{array}{l}\text { População } \\
\text { estudada }\end{array}$ & $\begin{array}{l}\text { Delineamento } \\
\text { do estudo e } \\
\text { NE }\end{array}$ & Objetivos & $\begin{array}{l}\text { Instrumentos/ } \\
\text { Procedimentos }\end{array}$ & Principais resultados \\
\hline $\begin{array}{l}\text { Behar, } \\
\text { Barrera, \& } \\
\text { Michelotti } \\
\text { (2003) }\end{array}$ & $\begin{array}{l}139 \text { mulheres com } \\
\text { TAs e } 82 \text { sem } \\
\text { quadro de TAs } \\
\text { (grupo controle). }\end{array}$ & $\begin{array}{l}\text { Quase } \\
\text { experimental } \\
\text { (NE 3) }\end{array}$ & $\begin{array}{l}\text { Comparar características } \\
\text { psicológicas e comportamentais } \\
\text { e traços de identidade de gênero } \\
\text { entre mulheres com e sem TAs. }\end{array}$ & $\begin{array}{c}\text { Entrevista semiestruturada } \\
\text { baseada nos critérios do } \\
\text { DSM-IV, Eating Attitudes } \\
\text { Test } 40 \text { (EAT-40), Eating } \\
\text { Disorders Inventory (EDI) e } \\
\text { Bem Sex Role Inventory } \\
\text { (BSRI). }\end{array}$ & $\begin{array}{l}\text { As mulheres com AN do tipo bulímico obtiveram pontuações } \\
\text { maiores nas subescalas de Drive for thiness, Perfectionism e } \\
\text { Interpersonal distrust do EDI. O grupo com AN do tipo } \\
\text { restritivo obteve maiores pontuações na subescala Maturity } \\
\text { fears. Já o grupo com BN obteve maiores pontuações nas } \\
\text { subescalas Body dissatisfaction, Inefectiveness e Interoceptive } \\
\text { awareness. As pacientes com AN do tipo restritivo } \\
\text { apresentaram maior porcentagem na categoria Feminine do } \\
\text { BSRI e a menor nas categorias Androgynous e Undifferentiated. } \\
\text { Conclui-se que a feminilidade emergiu como traço principal da } \\
\text { identidade de gênero de pacientes com TAs, em contraste com a } \\
\text { androgenia apresentada pelas mulheres saudáveis. }\end{array}$ \\
\hline $\begin{array}{l}\text { Moore \& Keel } \\
\quad \text { (2003) }\end{array}$ & $\begin{array}{c}47 \text { mulheres } \\
\text { heterossexuais e } 45 \\
\text { mulheres } \\
\text { homossexuais sem } \\
\text { diagnóstico de TAs. }\end{array}$ & $\begin{array}{l}\text { Não } \\
\text { experimental, } \\
\text { descritivo, } \\
\text { correlacional } \\
\text { (NE 4) }\end{array}$ & $\begin{array}{c}\text { Avaliar a influência da idade na } \\
\text { relação entre orientação sexual } \\
\text { e atitudes e comportamentos } \\
\text { alimentares disfuncionais em } \\
\text { mulheres sem diagnóstico de } \\
\text { TAs. }\end{array}$ & $\begin{array}{l}\text { Body Esteem Scale (BES), } \\
\text { Eating Disorders Inventory } \\
\quad(\text { EDI-2) e Reasons for } \\
\text { Exercise Inventory (REI). }\end{array}$ & $\begin{array}{l}\text { Os resultados não corroboraram a hipótese dos autores de que a } \\
\text { associação entre orientação sexual e atitudes alimentares } \\
\text { disfuncionais seria influenciada pela idade. As mulheres } \\
\text { homossexuais apresentaram menos desejo de emagrecer e } \\
\text { menor uso de exercício físico para controlar o peso do que as } \\
\text { mulheres heterossexuais. No entanto, não houve diferenças nas } \\
\text { subescalas Bulimia, Body Dissatisfaction e Weight Concern. } \\
\text { Esses dados sugerem que a orientação sexual pode influenciar } \\
\text { apenas alguns tipos de atitudes e comportamentos alimentares. } \\
\text { Foram encontradas mais semelhanças do que diferenças entre } \\
\text { mulheres homossexuais e heterossexuais. }\end{array}$ \\
\hline $\begin{array}{c}\text { Eddy, } \\
\text { Novotny, \& } \\
\text { Westen (2004) }\end{array}$ & $\begin{array}{l}234 \text { profissionais de } \\
\text { saúde que } \\
\text { trabalhavam com } \\
\text { pacientes com TAs. }\end{array}$ & $\begin{array}{l}\text { Não } \\
\text { experimental, } \\
\text { descritivo, } \\
\text { correlacional } \\
\text { (NE 4) }\end{array}$ & $\begin{array}{c}\text { Explorar a relação entre } \\
\text { psicopatologias alimentares e } \\
\text { sexualidade, enfatizando as } \\
\text { diferenças entre pacientes com } \\
\text { diferentes tipos de TAs, na } \\
\text { perspectiva de profissionais que } \\
\text { atuavam com pacientes com } \\
\text { TAs. }\end{array}$ & $\begin{array}{l}\text { Clinical Data Form-Eating } \\
\text { Disorders Version (CDF- } \\
\text { ED), Axis I Eating Disorder } \\
\text { Checklist, Shedler-Westen } \\
\text { Assesment Procedure-200 } \\
\text { (SWAP-200). }\end{array}$ & $\begin{array}{l}\text { Pacientes com AN tendem a se mostrar infantilizadas, enquanto } \\
\text { que pacientes com BN tendem a ser promíscuas e a manter } \\
\text { vários relacionamentos afetivos simultaneamente. } \\
\text { Personalidades permeadas por autocontrole e constrição foram } \\
\text { consideradas preditoras de sexualidade infantilizada, } \\
\text { independentemente do diagnóstico de AN, e personalidades } \\
\text { emocionalmente desreguladas, com dificuldades de } \\
\text { autocontrole, foram preditoras de comportamentos sexuais } \\
\text { impulsivos, para além do diagnóstico de BN. A personalidade } \\
\text { está por trás da relação entre alimentação e sexualidade em pelo } \\
\text { menos um subgrupo de mulheres com TAs. }\end{array}$ \\
\hline
\end{tabular}




\begin{tabular}{|c|c|c|c|c|c|}
\hline $\begin{array}{l}\text { Autores e ano } \\
\text { de publicação }\end{array}$ & $\begin{array}{l}\text { População } \\
\text { estudada }\end{array}$ & $\begin{array}{l}\text { Delineamento } \\
\text { do estudo e } \\
\text { NE }\end{array}$ & Objetivos & $\begin{array}{l}\text { Instrumentos/ } \\
\text { Procedimentos }\end{array}$ & Principais resultados \\
\hline $\begin{array}{l}\text { Romejko- } \\
\text { Borowiec } \\
(2004)\end{array}$ & $\begin{array}{l}73 \text { adolescentes e } \\
\text { jovens adultas com } \\
\text { TAs e } 31 \text { sem } \\
\text { condições clínicas. }\end{array}$ & $\begin{array}{l}\text { Quase } \\
\text { experimental } \\
\text { (NE 3) }\end{array}$ & $\begin{array}{l}\text { Investigar o desenvolvimento } \\
\text { sexual de adolescentes e jovens } \\
\text { adultas com TAs. }\end{array}$ & $\begin{array}{l}\text { Life Check List, Sentence } \\
\text { Completion Test (SCT) e } \\
\text { Self-rating Scale on Eating } \\
\text { Disorders. }\end{array}$ & $\begin{array}{l}\text { Os resultados confirmaram a relação entre TAs e disfunção } \\
\text { sexual. Os sintomas de TAs parecem possibilitar que as } \\
\text { pacientes prolonguem a realização das exigências dos papéis } \\
\text { femininos culturalmente impostos. Nesse sentido, acredita-se } \\
\text { que os TAs podem ser utilizados como meio de "resolução” de } \\
\text { conflitos de identidade sexual, mas esse mecanismo defensivo é } \\
\text { específico e fugaz. Dessa forma, as garotas podem evitar o } \\
\text { amadurecimento emocional e prorrogar o momento de se } \\
\text { confrontarem com os papéis de mulheres adultas. }\end{array}$ \\
\hline $\begin{array}{c}\text { Hepp, } \\
\text { Spindler, \& } \\
\text { Milos (2005) }\end{array}$ & $\begin{array}{l}68 \text { mulheres com } \\
\text { AN e } 123 \text { com BN. }\end{array}$ & $\begin{array}{l}\text { Não } \\
\text { experimental, } \\
\text { descritivo, } \\
\text { correlacional } \\
\text { (NE 4) }\end{array}$ & $\begin{array}{l}\text { Investigar a associações entre } \\
\text { papel de gênero e } \\
\text { psicopatologias alimentares. }\end{array}$ & $\begin{array}{l}\text { Bem Sex Role Inventory } \\
\text { (BSRI), Eating Disorders } \\
\text { Inventory (EDI) e a } \\
\text { subescala Sexual Anxiety do } \\
\text { instrumento Anorexia } \\
\text { Nervosa Inventory for Self- } \\
\text { Rating. }\end{array}$ & $\begin{array}{l}\text { As pontuações obtidas no BSRI foram negativamente } \\
\text { correlacionadas com comportamentos alimentares disfuncionais } \\
\text { autorrelatados. Indivíduos com altos níveis de androgenia } \\
\text { apresentaram menos sintomas de TAs do que os indiferenciados, } \\
\text { que mostraram altos níveis dessa sintomatologia. Feminilidade e } \\
\text { masculinidade, apesar de se tratarem de traços independentes, não } \\
\text { devem ser considerados isoladamente no contexto dos TAs. Em } \\
\text { mulheres que apresentam esses transtornos, a androgenia parece } \\
\text { estar associada com baixos níveis de sintomatologia de TAs. }\end{array}$ \\
\hline Heenan (2005) & - & $\begin{array}{l}\text { Exploratório e } \\
\text { descritivo (NE } \\
4)\end{array}$ & $\begin{array}{l}\text { Explorar o material clínico } \\
\text { obtido em um grupo de terapia } \\
\text { psicodinâmica feminista para } \\
\text { mulheres com diversos } \\
\text { problemas alimentares. }\end{array}$ & - & $\begin{array}{l}\text { A terapia psicodinâmica feminista possibilita que as pacientes } \\
\text { compreendam as conexões entre teorias socialmente construídas } \\
\text { de feminilidade, emoções e sensações corporais, ao invés de } \\
\text { agirem sobre estas por meio de alguma forma de abuso } \\
\text { corporal. É essencial combinar essas compreensões com } \\
\text { intervenções terapêuticas cognitivo- comportamentais, de forma } \\
\text { a fornecer uma estrutura na qual a comida, a alimentação e o } \\
\text { tamanho corporal cheguem a ser vistos como significativos. }\end{array}$ \\
\hline $\begin{array}{l}\text { Januszek } \\
\text { (2007) }\end{array}$ & $\begin{array}{l}30 \text { adolescentes do } \\
\text { sexo feminino com } \\
\text { AN e } 30 \text { sem } \\
\text { condições clínicas. }\end{array}$ & $\begin{array}{l}\text { Quase } \\
\text { experimental } \\
\text { (NE 3) }\end{array}$ & $\begin{array}{l}\text { Investigar a identidade sexual } \\
\text { de jovens mulheres com AN. }\end{array}$ & $\begin{array}{l}\text { Técnica Q, Inventory for the } \\
\text { Evalutation of Psychological } \\
\text { Sex (IPP) e Questionnaire of } \\
\text { Personal Characteristics. }\end{array}$ & $\begin{array}{c}\text { Ficaram evidenciados níveis significativamente mais baixos de } \\
\text { autoestima no que concerne às características relacionadas ao sexo } \\
\text { em pacientes com AN em comparação com as adolescentes do } \\
\text { grupo controle. Além disso, evidenciaram-se algumas incoerências } \\
\text { no aspecto conceitual da identidade sexual. Enfatiza-se a necessidade } \\
\text { de que a psicoterapia com adolescentes com AN inclua o trabalho } \\
\text { com o conceito de feminilidade. }\end{array}$ \\
\hline
\end{tabular}




\begin{tabular}{|c|c|c|c|c|c|}
\hline $\begin{array}{l}\text { Autores e ano } \\
\text { de publicação }\end{array}$ & $\begin{array}{l}\text { População } \\
\text { estudada }\end{array}$ & $\begin{array}{l}\text { Delineamento } \\
\text { do estudo e } \\
\text { NE }\end{array}$ & Objetivos & $\begin{array}{l}\text { Instrumentos/ } \\
\text { Procedimentos }\end{array}$ & Principais resultados \\
\hline $\begin{array}{l}\text { Green et al. } \\
\quad(2008)\end{array}$ & $\begin{array}{c}86 \text { estudantes } \\
\text { universitárias, com } \\
\text { idades entre } 17 \text { e } 23 \\
\text { anos. }\end{array}$ & $\begin{array}{l}\text { Não } \\
\text { experimental, } \\
\text { descritivo, } \\
\text { correlacional } \\
\text { (NE 4) }\end{array}$ & $\begin{array}{c}\text { Examinar se a conformidade com } \\
\text { as normas femininas tradicionais } \\
\text { seria preditor de TAs. }\end{array}$ & $\begin{array}{l}\text { Eating Disorder Examination- } \\
\text { Questionnaire (EDE-Q) e } \\
\text { Conformity to Feminine } \\
\text { Norms Inventory (CFNI). }\end{array}$ & $\begin{array}{l}\text { Evidenciou-se que a valorização da magreza é o fator mais importante na } \\
\text { relação entre alta conformidade com as normas tradicionais de gênero e } \\
\text { níveis mais elevados de TAs. Esse dado foi indicado pela elevada } \\
\text { pontuação na subescala Thiness do CFNI. Outras normas tradicionais de } \\
\text { gênero não indicaram relações significativas com os sintomas de TAs, } \\
\text { conforme evidenciado pelo CFNI. }\end{array}$ \\
\hline $\begin{array}{l}\text { Pinheiro et al. } \\
\text { (2010) }\end{array}$ & $\begin{array}{l}242 \text { mulheres com } \\
\text { TA e grupo controle. }\end{array}$ & $\begin{array}{l}\text { Quase } \\
\text { experimental } \\
\text { (NE 3) }\end{array}$ & $\begin{array}{l}\text { Descrever o funcionamento } \\
\text { sexual de mulheres com TAs. }\end{array}$ & $\begin{array}{l}\text { Structured Interview for } \\
\text { Anorexic and Bulimic } \\
\text { Disorders-psychopathology } \\
\text { (SIAB-P), Temperament and } \\
\text { Character Inventory (TCI), } \\
\text { Frost Multidimentional } \\
\text { Perfectionism Scale (MPS), } \\
\text { State-Trait Anxiety Inventory } \\
\text { (STAI) e Eating Disorder } \\
\text { Inventory-2 (EDI-2). }\end{array}$ & $\begin{array}{l}\text { Manter relação sexual, ter um parceiro, manifestar diminuição do desejo } \\
\text { sexual e aumento da ansiedade sexual foram traços comuns aos dois } \\
\text { grupos investigados. Mulheres com AN dos tipos restritivo e purgativo } \\
\text { mostraram maior prevalência de perda da libido do que mulheres com BN } \\
\text { e TA não-especificado. Ausência de relações sexuais foi associada com } \\
\text { baixo IMC ao longo da vida e ocorrência precoce do TA. Perda da libido } \\
\text { foi associada com baixo IMC, altos níveis de consciência interoceptiva e } \\
\text { traços de ansiedade. Ansiedade sexual foi associada com baixo IMC, } \\
\text { condutas de evitação de danos e sentimento de baixa autoeficácia. A } \\
\text { incidência de disfunções sexuais nas mulheres com TAs foi maior do que } \\
\text { na amostra normativa. }\end{array}$ \\
\hline $\begin{array}{c}\text { Capitaine, } \\
\text { Rodgers, \& } \\
\text { Chabrol (2011) }\end{array}$ & $\begin{array}{c}122 \text { estudantes } \\
\text { universitárias, com } \\
\text { idades entre } 18 \text { e } 28 \\
\text { anos. }\end{array}$ & $\begin{array}{l}\text { Não } \\
\text { experimental, } \\
\text { descritivo, } \\
\text { correlacional } \\
\text { (NE 4) }\end{array}$ & $\begin{array}{l}\text { Examinar a relação entre relações } \\
\text { sexuais indesejadas, satisfação } \\
\text { sexual, sintomas depressivos e } \\
\text { perturbações alimentares. }\end{array}$ & $\begin{array}{l}\text { Eating Attitudes Test-26 } \\
\text { (EAT-26), Centre for } \\
\text { Epidemiological Studies - } \\
\text { Depression Scale (CES-D), } \\
\text { Sexual Experience Survey } \\
\text { (SES) e Visual Analog Scale } \\
\text { (VAS). }\end{array}$ & $\begin{array}{l}\text { Os resultados indicaram, de forma geral, que as relações sexuais } \\
\text { indesejadas estavam relacionadas ao desenvolvimento de } \\
\text { perturbações alimentares e que sintomas depressivos pareceram } \\
\text { mediar essa relação. Os dados enfatizam as altas taxas de } \\
\text { experiências sexuais indesejadas entre as estudantes universitárias, } \\
\text { e sugerem que as vítimas dessas experiências devem ser avaliadas } \\
\text { para possível ocorrência de depressão. }\end{array}$ \\
\hline $\begin{array}{l}\text { Woolhouse, } \\
\text { Day, Rickett, \& } \\
\text { Milnes (2012) }\end{array}$ & $\begin{array}{l}37 \text { adolescentes e } \\
\text { jovens adultas de } \\
\text { escolas e de uma } \\
\text { universidade do } \\
\text { Reino Unido. }\end{array}$ & $\begin{array}{l}\text { Exploratório e } \\
\text { descritivo (NE } \\
4 \text { ) }\end{array}$ & $\begin{array}{l}\text { Investigar discursos de jovens } \\
\text { mulheres acerca dos temas: } \\
\text { comida, alimentação, } \\
\text { feminilidades, corpo e } \\
\text { incorporação de papéis sociais } \\
\text { tradicionalmente femininos. }\end{array}$ & $\begin{array}{l}\text { Roteiro de entrevista } \\
\text { semiestruturada. }\end{array}$ & $\begin{array}{l}\text { Significados culturais dominantes sobre corpo, tamanho, forma, comida } \\
\text { e alimentação foram frequentemente reproduzidos pelos discursos das } \\
\text { participantes. Corpos magros foram retratados como símbolo de sucesso } \\
\text { social, econômico e cultural; restrição e abnegação indicavam controle, } \\
\text { autodisciplina e virtude moral; gordura foi considerada como marca de } \\
\text { desvio ou ausência de autodisciplina, e algo a "ser queimado”; a } \\
\text { alimentação aparece como fonte de culpa e vergonha, e a comida como } \\
\text { pecaminosa e um inimigo a ser derrotado. No entanto, as participantes } \\
\text { também puderam criar espaços discursivos alternativos para romper e } \\
\text { desafiar significados culturalmente dominantes. }\end{array}$ \\
\hline
\end{tabular}




\begin{tabular}{|c|c|c|c|c|c|}
\hline $\begin{array}{l}\text { Autores e ano } \\
\text { de publicação }\end{array}$ & $\begin{array}{l}\text { População } \\
\text { estudada }\end{array}$ & $\begin{array}{c}\text { Delineamento } \\
\text { do estudo e } \\
\text { NE }\end{array}$ & Objetivos & $\begin{array}{l}\text { Instrumentos/ } \\
\text { Procedimentos }\end{array}$ & Principais resultados \\
\hline $\begin{array}{c}\text { Cella, } \\
\text { Iannaccone, \& } \\
\text { Cotrufo (2013) }\end{array}$ & $\begin{array}{l}132 \text { homossexuais, } \\
178 \text { heterossexuais } \\
\text { (tanto mulheres } \\
\text { quanto homens) e } \\
15 \text { transexuais } \\
\text { (homens que se } \\
\text { transformaram em } \\
\text { mulheres). }\end{array}$ & $\begin{array}{l}\text { Não- } \\
\text { experimental, } \\
\text { correlacional } \\
\text { (NE 4) }\end{array}$ & $\begin{array}{l}\text { Investigar a relação entre papel } \\
\text { de gênero, atitudes e } \\
\text { comportamentos alimentares } \\
\text { disfuncionais e insatisfação } \\
\text { corporal em uma amostra de } \\
\text { homossexuais, heterossexuais e } \\
\text { transexuais. }\end{array}$ & $\begin{array}{c}\text { Tabela de dados } \\
\text { sociodemográficos, Eating } \\
\text { Disorders Inventory -2 (EDI- } \\
\text { 2), Body Uneasiness Test } \\
\text { (BUT) e Bem Sex Role } \\
\text { Inventory (BSRI). }\end{array}$ & $\begin{array}{l}\text { De forma geral, foram evidenciadas diferenças entre } \\
\text { participantes homossexuais, heterossexuais e transexuais. Os } \\
\text { resultados indicaram que a feminilidade parece estar } \\
\text { relacionada aos problemas alimentares, diferentemente da } \\
\text { masculinidade. Participantes femininas, independentemente do } \\
\text { gênero biológico ou do papel de gênero, apresentaram atitudes } \\
\text { alimentares mais disfuncionais do que indivíduos com traços } \\
\text { masculinos, andrógenos ou indiferenciados. }\end{array}$ \\
\hline $\begin{array}{l}\text { Castellini et al. } \\
\text { (2013) }\end{array}$ & $\begin{array}{l}27 \text { pacientes com } \\
\text { AN e } 31 \text { com BN } \\
\text { foram avaliadas no } \\
\text { início do } \\
\text { aparecimento dos } \\
\text { sintomas e após um } \\
\text { ano de tratamento } \\
\text { com terapia } \\
\text { cognitivo- } \\
\text { comportamental } \\
\text { (TCC). }\end{array}$ & $\begin{array}{l}\text { Quase } \\
\text { experimental, } \\
\text { longitudinal } \\
\text { (NE 3) }\end{array}$ & $\begin{array}{l}\text { Avaliar o curso longitudinal do } \\
\text { funcionamento sexual, assim } \\
\text { como o modo pelo qual as } \\
\text { mudanças na psicopatologia e a } \\
\text { história de abuso sexual na } \\
\text { infância interagem com o } \\
\text { funcionamento sexual em } \\
\text { pacientes com AN e BN. }\end{array}$ & $\begin{array}{l}\text { Structured Clinical Interview } \\
\text { for Diagnostic and Statistical } \\
\text { Manual of Mental Disorders IV } \\
\text { (SCI - DSM-IV), Female } \\
\text { Sexual Function Index (FSFI), } \\
\text { Eating Disorder Examination } \\
\text { Questionnaire (EDEQ), Beck } \\
\text { Depression Inventory (BDI), } \\
\text { Spielberg's State-Trait Anxiety } \\
\text { Inventory (SSTAI), Symptom } \\
\text { Checklist-90 e Childhood } \\
\text { Experience of Care and Abuse } \\
\text { Questionnaire (CECAQ). }\end{array}$ & $\begin{array}{l}\text { Todas as participantes apresentaram melhora significativa em } \\
\text { todos os domínios do funcionamento sexual, exceto as que } \\
\text { tinham histórico de abuso sexual. A redução dos sintomas de } \\
\text { TAs estava associada à melhoria do funcionamento sexual, } \\
\text { novamente à exceção das mulheres que apresentavam histórico } \\
\text { de abuso sexual. Em suma, as psicopatologias alimentares } \\
\text { podem ser consideradas fatores de manutenção da disfunção } \\
\text { sexual em indivíduos diagnosticados com TAs. Indivíduos com } \\
\text { histórico de abuso sexual representam uma subpopulação de } \\
\text { pacientes com profundo mal-estar envolvendo a percepção } \\
\text { corporal e o funcionamento sexual, que parece não ter sido } \\
\text { adequadamente abordado durante a intervenção de TCC. }\end{array}$ \\
\hline $\begin{array}{c}\text { Simoni \& } \\
\text { Bastos (2013) }\end{array}$ & - & $\begin{array}{l}\text { Exploratório e } \\
\text { descritivo, de } \\
\text { reflexão } \\
\text { teórica (NE 4) }\end{array}$ & $\begin{array}{l}\text { Investigar as relações entre o } \\
\text { sintoma anoréxico e a } \\
\text { feminilidade. Parte-se da } \\
\text { hipótese de que o sintoma } \\
\text { anoréxico configura uma } \\
\text { resposta de algumas jovens } \\
\text { diante das consequências da } \\
\text { sexuação e do encontro com o } \\
\text { gozo feminino. }\end{array}$ & - & $\begin{array}{l}\text { De forma geral, a anorexia em crianças, jovens e indivíduos } \\
\text { adultos do sexo feminino envolve não simplesmente a questão da } \\
\text { sexualidade, mas da sexuação. Esta última não encontra um estado } \\
\text { resolutivo na infância e, portanto, exige mudanças do objeto de } \\
\text { investimento libidinal e deslocamento da erogeneidade corporal. A } \\
\text { alta incidência de anorexia entre adolescentes e jovens mulheres } \\
\text { não parece, por conseguinte, uma forma de expressão do feminino, } \\
\text { nem uma recusa da feminilidade, mas uma resposta à irrupção do } \\
\text { gozo no corpo. As anorexias que primam pela apreensão de um } \\
\text { corpo dilatado ou disforme, antes de constituírem uma } \\
\text { psicopatologia da imagem, traduzem o retorno na autoimagem } \\
\text { corporal de algo que se tenta cifrar, levando à insistência em } \\
\text { extirpar a gordura suplementar. }\end{array}$ \\
\hline
\end{tabular}




\begin{tabular}{|c|c|c|c|c|c|}
\hline $\begin{array}{l}\text { Autores e ano } \\
\text { de publicação }\end{array}$ & $\begin{array}{l}\text { População } \\
\text { estudada }\end{array}$ & $\begin{array}{l}\text { Delineamento } \\
\text { do estudo e } \\
\text { NE }\end{array}$ & Objetivos & $\begin{array}{l}\text { Instrumentos/ } \\
\text { Procedimentos }\end{array}$ & Principais resultados \\
\hline $\begin{array}{l}\text { Yean et al. } \\
\text { (2013) }\end{array}$ & $\begin{array}{l}693 \text { estudantes } \\
\text { universitários, } \\
\text { sendo } 246 \text { do sexo } \\
\text { masculino e } 447 \text { do } \\
\text { sexo feminino. }\end{array}$ & $\begin{array}{c}\text { Não } \\
\text { experimental, } \\
\text { descritivo, } \\
\text { correlacional } \\
\text { (NE 4) }\end{array}$ & $\begin{array}{l}\text { Examinar: (1) as diferenças } \\
\text { determinadas pelo sexo e pela } \\
\text { orientação sexual na } \\
\text { internalização da pressão social } \\
\text { para modificar a aparência } \\
\text { física, nos componentes } \\
\text { emocionais da insatisfação com } \\
\text { a imagem corporal, autoestima } \\
\text { e sintomatologia de TA; (2) se } \\
\text { essa internalização e os } \\
\text { sintomas de TAs foram } \\
\text { mediados pelos diversos } \\
\text { componentes da insatisfação } \\
\text { com a imagem corporal e pela } \\
\text { baixa autoestima. }\end{array}$ & $\begin{array}{l}\text { Kinsey Heterosexual- } \\
\text { Homosexual Likert-type } \\
\text { Scale, Body Shape } \\
\text { Questionnaire (BSQ), Eating } \\
\text { Attitudes Test-26 (EAT-26), } \\
\text { escala Drive for Thinness do } \\
\text { Eating Disorder Inventory- } \\
\text { II(DFT, EDI-II), Drive for } \\
\text { Muscularity Scale (DFM), } \\
\text { Rosenberg Self-Esteem Scale } \\
\text { (RSES) e Sociocultural } \\
\text { Attitudes Towards } \\
\text { Appearance Scale-3 } \\
\text { (SATAQ). }\end{array}$ & $\begin{array}{l}\text { Homens apresentaram menores índices de: insatisfação corporal, } \\
\text { internalização do ideal cultural de beleza, desejo de emagrecer e } \\
\text { alimentação disfuncional. Porém, mostraram altos índices de desejo } \\
\text { de ganho muscular, ao contrário das mulheres. Os resultados } \\
\text { também indicaram que diversos componentes da insatisfação com a } \\
\text { imagem corporal e da baixa autoestima mediaram parcialmente a } \\
\text { relação entre a internalização e a sintomatologia de TAs. Homens } \\
\text { gays referiram índices significativamente mais altos do que os } \\
\text { heterossexuais em relação à insatisfação com a imagem corporal, } \\
\text { internalização do ideal cultural de beleza, sintomatologia de TA, } \\
\text { desejo de emagrecer e de ganhar músculos. Comparadas com } \\
\text { mulheres heterossexuais, as homossexuais apresentaram altos } \\
\text { índices de: desejo de ganhar músculos, baixa autoestima e baixa } \\
\text { internalização; no entanto, não apresentavam índices significativos } \\
\text { de insatisfação corporal, desejo de emagrecer e sintomas de TA. }\end{array}$ \\
\hline $\begin{array}{l}\text { Collins, } \\
\text { Fischer, Stojek } \\
\text { \& Becker } \\
\text { (2014) }\end{array}$ & $\begin{array}{c}319 \text { estudantes } \\
\text { universitárias, com } \\
\text { idade média de } 18 \\
\text { anos. }\end{array}$ & $\begin{array}{l}\text { Não } \\
\text { experimental, } \\
\text { prospectivo, } \\
\text { correlacional } \\
\text { (NE 4) }\end{array}$ & $\begin{array}{l}\text { Examinar a interação de abuso } \\
\text { sexual recente (ou tentativa de } \\
\text { abuso) com diferenças } \\
\text { individuais na supressão de } \\
\text { pensamentos, e de que modo } \\
\text { essa interação resulta no } \\
\text { aumento de sintomas de TAs } \\
\text { durante adolescência tardia e/ou } \\
\text { início da vida adulta. }\end{array}$ & $\begin{array}{c}\text { Eating Disorder Examination } \\
\text { Questionnaire (EDE-Q), } \\
\text { White Bear Thought } \\
\text { Suppression Inventory } \\
\text { (WBSI), Sexual Experiences } \\
\text { Survey (SES), Childhood } \\
\text { Trauma Questionnaire } \\
\text { (CTQ). }\end{array}$ & $\begin{array}{l}\text { Os resultados indicaram que abuso sexual recente ou tentativa } \\
\text { de abuso, em conjunto com o uso de supressão crônica de } \\
\text { pensamento, foi associada com aumento global de sintomas de } \\
\text { TAs, mesmo após o controle estatístico da influência de } \\
\text { comportamentos alimentares disfuncionais anteriores ao abuso. } \\
\text { Corroborou-se a hipótese de que a supressão de pensamento se } \\
\text { tratava de uma estratégia pela qual o abuso sexual podia afetar } \\
\text { o curso do comportamento alimentar, aumentando a ocorrência } \\
\text { de sintomas disfuncionais. }\end{array}$ \\
\hline $\begin{array}{l}\text { Matthews- } \\
\text { Ewald, } \\
\text { Zulling, \& } \\
\text { Ward (2014) }\end{array}$ & $\begin{array}{l}110 \text { estudantes } \\
\text { universitários (não } \\
\text { foi discriminado o } \\
\text { número de } \\
\text { participantes } \\
\text { segundo gênero } \\
\text { masculino e } \\
\text { feminino). }\end{array}$ & $\begin{array}{c}\text { Não } \\
\text { experimental, } \\
\text { descritivo, } \\
\text { correlacional } \\
\text { (NE 4) }\end{array}$ & $\begin{array}{l}\text { Comparar o risco de: a) TAs } \\
\text { clinicamente diagnosticados, e } \\
\text { b) comportamentos alimentares } \\
\text { disfuncionais, separadamente, } \\
\text { entre três grupos de estudantes } \\
\text { universitários que se } \\
\text { identificavam como: 1) gay/ } \\
\text { lésbicas; 2) bissexuais; 3) } \\
\text { incertos, com heterossexuais de } \\
\text { referência. }\end{array}$ & $\begin{array}{c}\text { American College Health } \\
\text { Association National College } \\
\text { Health Assessment (ACHA- } \\
\text { NCHA). }\end{array}$ & $\begin{array}{l}\text { Homens que se encaixam no conceito de "sex minorities” (SM), } \\
\text { ou seja, gays, bissexuais ou incertos de sua sexualidade, } \\
\text { apresentavam maior probabilidade de desenvolver } \\
\text { comportamentos alimentares disfuncionais ou TAs clinicamente } \\
\text { diagnosticados, quando comparados a homens heterossexuais. } \\
\text { Em relação às mulheres, fazer parte de SMs não constitui fator } \\
\text { de risco para o desenvolvimento de TAs ou alimentação } \\
\text { disfuncional. Mulheres SMs apresentavam apenas hábitos de } \\
\text { fazer dieta, que não foram considerados comportamentos } \\
\text { alimentares disfuncionais, tais como vômitos e uso de laxante. }\end{array}$ \\
\hline
\end{tabular}


Os resultados evidenciados nesta revisão foram organizados e agrupados em cinco categorias temáticas, que serão apresentadas e discutidas a seguir.

\section{Gênero, orientação sexual e TAs}

Foram encontrados nove artigos que se enquadram nessa categoria. Predomina nestes estudos o interesse pelas questões de gênero e orientação sexual na interface com os TAs. Meyer, Blisset e Oldfield (2001) realizaram um estudo com estudantes universitários homo e heterossexuais de ambos os sexos, buscando verificar a relação entre orientação sexual e sintomas de TAs, tomando como base o pressuposto de que a homossexualidade configura um importante fator de risco para o desenvolvimento desses quadros. Os autores partiram da hipótese de que homens e mulheres homossexuais com traços físicos e emocionais predominantemente femininos apresentam comportamentos e atitudes alimentares disfuncionais, enquanto que traços de masculinidade seriam associados a menores índices de psicopatologia alimentar. Os resultados deste estudo indicaram que indivíduos com altos índices de feminilidade apresentaram também elevados índices de comportamentos alimentares restritivos, enquanto que indivíduos com altos índices de masculinidade apresentaram baixos índices desses comportamentos. De forma geral, evidenciou-se que a feminilidade estava associada a altos níveis de psicopatologia alimentar, enquanto que a masculinidade estava associada a comportamentos e atitudes alimentares saudáveis. Tais resultados embasam a construção de um modelo no qual a feminilidade caracteriza um fator de risco para a ocorrência de TAs, ao passo que a masculinidade caracteriza um fator de proteção para esses quadros. Os autores atribuem tal modelo a fatores culturais da sociedade ocidental, que valoriza exageradamente a magreza feminina.

De forma semelhante, More e Keel (2003) partiram do pressuposto consolidado pela literatura científica de que a homossexualidade feminina - na qual o traço de feminilidade é acentuado - atua como fator de proteção contra a ocorrência de sintomas de TAs, assim como a masculinidade mencionada por Meyer et al. (2001). No entanto, More e Keel também apontaram resultados de pesquisas que contradizem esses pressupostos, sugerindo que algumas mulheres homossexuais apresentam altos índices de compulsão alimentar. Essa divergência na literatura pode ser explicada pela diferença entre as amostras investigadas por vários estudos que abordam a questão da sexualidade nos TAs, o que indica que as mudanças ocorridas ao longo do ciclo de vida podem afetar a vulnerabilidade para o desenvolvimento desses quadros. Nesse sentido, os autores buscaram testar a hipótese de que a associação entre orientação sexual e psicopatologias alimentares nas mulheres é influenciada pela idade. Os 
resultados do estudo não corroboraram tal hipótese. Mulheres homossexuais relataram menos desejo de emagrecer e faziam menos uso do exercícios físicos para perder peso quando comparadas a mulheres heterossexuais. No entanto, não houve diferenças significativas nas escalas Bulimia, Body Dissatisfaction e Weight Concern do EDI-2, o que sugere que a orientação sexual pode influenciar apenas alguns tipos de atitudes e comportamentos alimentares disfuncionais em mulheres. Foram encontradas mais semelhanças do que diferenças entre mulheres homo e heterossexuais.

Behar, Barrera e Michelotti (2003) encontraram resultados semelhantes aos estudos mencionados nos parágrafos anteriores no que diz respeito à feminilidade como fator de risco para a ocorrência de TAs. O estudo teve como objetivo comparar características psicológicas, comportamentais e traços de identidade de gênero entre mulheres com e sem TAs. Por identidade de gênero entende-se o estereótipo adquirido pelos indivíduos a partir do sistema de crenças e comportamentos atribuídos ao sexo masculino e feminino pela sociedade, sendo que tal estereótipo pode se tornar bastante aversivo para alguns indivíduos, estando relacionados à insatisfação corporal e a psicopatologias alimentares (Behar, Barrera, \& Michelotti, 2003). Os resultados indicaram que as mulheres com TAs se identificaram mais com o estereótipo tradicional do gênero feminino do que as mulheres sem esta condição psicopatológica. Além disso, as mulheres acometidas foram caracterizadas como mais propensas a serem femininas, infantis, temperamentais, ambiciosas, desejosas de receberem elogios e de terem uma posição social elevada. Já as mulheres sem psicopatologia foram apresentadas como mais felizes, confiantes, compreensivas, independentes, autossuficientes e capazes de tomar decisões. A feminilidade, portanto, emergiu como o principal traço da identidade de gênero em pacientes com TAs.

Matthews-Ewald, Zulling e Ward (2014) buscaram comparar o risco de: a) TAs clinicamente diagnosticados, e b) comportamentos alimentares disfuncionais, separadamente, entre três grupos de estudantes universitários que se identificavam como: 1) gay/ lésbicas; 2) bissexuais; 3) incertos, com heterossexuais de referência. Os três grupos avaliados configuravam o que os autores nomearam de “sex minorities” (SMs), referindo-se à predominância de indivíduos heterossexuais. Foram avaliados 110 estudantes, sendo que não foi apresentado o número discriminado de participantes do sexo masculino e feminino. Evidenciou-se que homens que se encaixam no conceito de SMs, ou seja, gays, bissexuais ou incertos de sua sexualidade, apresentavam maior probabilidade de desenvolver comportamentos alimentares disfuncionais ou TAs clinicamente diagnosticados, quando comparados a homens heterossexuais. Em relação às mulheres, fazer parte de SMs não 
constituía fator de risco para o desenvolvimento de TAs ou alimentação disfuncional. Mulheres SMs apresentavam apenas hábitos de fazer dieta, que não foram considerados comportamentos alimentares disfuncionais, tais como vômitos e uso de laxante. Acredita-se que os resultados apontados por Matthews-Ewald, Zullig e Ward (2014) estejam diretamente relacionados com os estudos descritos anteriormente nesta revisão (Behar, Barrera, \& Michelotti, 2003; More \& Keel, 2003; Meyer, Blisset, \& Oldfield, 2001), que indicaram que a feminilidade - muito presente em homens homossexuais, e raramente presente em mulheres homossexuais - mantinha estreita relação com comportamentos alimentares disfuncionais. Reforça-se, portanto, que a feminilidade representa fator de risco para a ocorrência de TAs. Vale ressaltar que o estudo de Matthews-Ewald, Zullig e Ward (2014) diverge do estudo de More e Keel (2003) no que diz respeito à realização de dietas por parte de mulheres homossexuais: os primeiros autores pontuam que lésbicas, bissexuais e mulheres incertas de sua sexualidade apresentam hábitos frequentes de dieta, enquanto que More e Keel (2003) sugerem que tais hábitos são raros ou ausentes em mulheres SMs.

Segundo Hepp, Spindler e Milos (2005), o papel de gênero pode ser definido como a posição que o indivíduo assume como ser masculino ou feminino, tomando como base os conceitos socialmente construídos acerca do estereótipo cultural desses construtos, ou seja, os comportamentos, atitudes, interesses e características de personalidade considerados tipicamente masculinos ou femininos. No entanto, os autores consideram que masculino e feminino não são extremos de um continuum, mas, ao contrário, o papel de gênero de um indivíduo pode integrar traços de ambos. Considerando-se que o papel de gênero remete à autopercepção, autoestima, imagem corporal e satisfação corporal - aspectos psicológicos centrais nos TAs -, Hepp, Spindler e Milos (2005) realizaram um estudo que teve como objetivo investigar a relação entre papel de gênero e TAs. Diferentemente dos estudos mencionados anteriormente, os resultados do estudo de Hepp, Spindler e Milos (2005) evidenciaram que a feminilidade não estava diretamente relacionada aos sintomas centrais dos TAs, mas apenas a sintomas psicopatológicos não especificados relacionados a esses quadros. Portanto, os resultados não corroboraram a hipótese central de que a feminilidade configuraria um fator de risco para a ocorrência de TAs. A masculinidade, por sua vez, foi definida como fator de proteção contra os TAs, em convergência com a literatura.

Ainda abordando a questão do papel de gênero, o estudo de Cella, Iannaccone e Cotrufo (2013) incorporou evidências que corroboraram a literatura no que diz respeito à feminilidade como fator de risco para os TAs, divergindo dos dados apresentados por Hepp, Spindler e Milos (2005). O estudo em questão teve como objetivo investigar a relação entre 
papel de gênero - que vai além do sexo biológico e da orientação sexual -, atitudes e comportamentos alimentares disfuncionais e insatisfação corporal em uma amostra de pessoas homo, hetero e transexuais. Os resultados evidenciaram relação positiva entre feminilidade e atitudes alimentares disfuncionais, e relação negativa entre masculinidade e tais atitudes. Participantes com traços femininos, independentemente do sexo biológico e da orientação sexual, apresentaram índices mais elevados de sintomas de TAs do que participantes com traços de masculinidade, androgenia e/ou sexualmente indiferenciados. Orientação homossexual foi associada a maior insatisfação corporal e comportamentos alimentares anormais em homens mais do que em mulheres. De forma geral, concluiu-se que a feminilidade pode ser considerada como fator de risco para o desenvolvimento de TAs, e que homens com transtornos de identidade de gênero podem ser mais vulneráveis a psicopatologias alimentares do que homens heterossexuais.

Tomando-se por base o pressuposto de que dificuldades para desenvolver uma identidade sexual exercem importante influência no processo de adoecimento e desencadeamento dos sintomas de TAs, Januszek (2007) buscou investigar componentes da identidade sexual de adolescentes com AN, comparando-as com adolescentes que não apresentavam condições clínicas (grupo controle). Tais componentes envolviam: o "Eu real”, o desejado "Eu ideal” e o normativo “Eu ideal”. Em relação ao “Eu real”, as adolescentes com AN se consideravam: menos sociáveis, seguras de si, emocionalmente fortes, com menos senso de humor e menor propensão a terem experiências sexuais. Consideravam-se como menos corajosas, animadas, hábeis ou enérgicas do que as adolescentes sem condição clínica. Também se descreveram com mais características estereotípicas femininas: se percebiam mais chorosas, fracas e carentes, tímidas, caprichosas, submissas e sensíveis. Em relação ao desejado "Eu ideal”, as adolescentes de ambos os grupos declararam desejar ter mais características relativas ao estereótipo masculino do que ao feminino. Concluiu-se que a baixa autoestima na área da sexualidade guarda relação com as discrepâncias entre o "Eu real”, o desejado "Eu ideal” e o normativo "Eu ideal”, e pode dificultar que as adolescentes com AN desenvolvam um conceito coerente de si mesmas enquanto mulheres, o que poderia, por sua vez, dificultar a aquisição e desempenho de papéis sexuais e o alcance de uma identidade sexual madura. Nesse sentido, uma das possíveis formas de lidar com tais dificuldades seria concentrar-se apenas nos atributos externos de gênero, tais como a aparência, e também aceitar o papel de pessoa adoecida que, até certo ponto, alivia a necessidade de assumir papéis sexuais maduros. 
Por fim, o estudo desenvolvido por Yean et al. (2013) trouxe resultados semelhantes aos dos artigos previamente apresentados. O estudo teve como objetivo examinar: (1) as diferenças desempenhadas pelo sexo e pela orientação sexual na internalização da pressão social para modificação da aparência física, nos componentes emocionais da insatisfação com a imagem corporal, autoestima e sintomatologia de TAs; (b) se essa internalização e os sintomas de TAs foram mediados pelos diversos componentes da insatisfação com a imagem corporal e pela autoestima. Os dados obtidos corroboraram a literatura ao indicarem, de forma geral, que homens apresentam menos insatisfação com o corpo, internalização do ideal cultural de magreza, desejo de emagrecer e alimentação disfuncional. No entanto, os homens apresentaram altos índices de desejo de ganhar massa muscular, ao contrário das mulheres. Os resultados também indicaram que diversos componentes da insatisfação com a imagem corporal e da baixa autoestima mediaram parcialmente a relação entre a internalização das normas culturais e a sintomatologia de TAs. Homens homossexuais referiram índices significativamente mais elevados do que heterossexuais em relação à insatisfação com a imagem corporal, internalização, sintomatologia de TAs, desejo de emagrecer e de ganhar massa muscular. Comparadas às mulheres heterossexuais, as homossexuais apresentaram altos índices de desejo de ganhar músculos, baixa autoestima e baixa internalização. No entanto, estas últimas não apresentavam índices significativos de insatisfação corporal, desejo de emagrecer e sintomas de TAs.

Os estudos analisados até o presente momento apontam, de forma geral, para a importância de se estudar a identidade e o papel de gênero no contexto dos TAs, devido ao fato de esses construtos proporcionarem dados para a análise do contexto sociocultural subjacente aos quadros psicopatológicos. Ou seja, os estudos relacionam os transtornos ao que é cultural e socialmente imposto para os homens e mulheres como ideal de beleza e sucesso, e demonstram que esse ideal parece ser mais presente nas atitudes e comportamentos de indivíduos com traços de personalidade femininos - incluindo homens com orientação homossexual - do que em indivíduos com traços masculinos.

Buscando lançar um olhar mais além da questão da sexualidade, Simoni e Bastos (2013) partiram do pressuposto de que a AN entre as mulheres jovens envolve aspectos da sexuação, ou seja, do processo de tornar-se mulher, da assunção do sexo feminino, tomando o sintoma anoréxico como uma possível resposta frente às consequências da sexuação e do encontro com o gozo feminino. As autoras partiram dos escritos de Freud e Lacan para elaborar um estudo exploratório e descritivo, de reflexão teórica, no qual propõem que a AN seja entendida como uma resposta à irrupção do gozo no corpo feminino, e não apenas uma 
recusa da feminilidade. "Enquanto a sexualidade infantil se configura de acordo com a organização fálica, as transformações da puberdade confrontam a adolescente com o gozo feminino não absorvido pelo falo. Agora, trata-se de um gozo do corpo, de um gozo suplementar, com o qual a jovem consente ou que a confronta com impasses na impossibilidade de fazê-lo passar ao significante” (Simoni \& Bastos, 2013, p. 418). As autoras enfatizam, portanto, a necessidade de que as peculiaridades do gozo feminino e de sua assunção sejam consideradas na clínica psicanalítica de pacientes com AN.

\section{Atitudes frente à sexualidade, experiências adversas e suas relações com os TAs}

Essa segunda categoria engloba as atitudes de mulheres acometidas por TAs frente à sexualidade, ou seja, a maneira como essas mulheres tendem a lidar com a sexualidade, de que forma a ocorrência de experiências adversas pode influenciar essas atitudes e de que modo esses eventos podem estar relacionados com a precipitação e/ou manutenção dos sintomas de TAs. Nessa categoria foram agrupados sete estudos que, de maneira geral, abordaram esses temas.

Por meio de um estudo exploratório e descritivo, de reflexão teórica, Ghizzani e Montomoli (2000) buscaram investigar o tema da sexualidade em mulheres com AN. Os autores abordaram vários aspectos que permeiam o quadro, enfatizando sobretudo a questão da imagem corporal, uma vez que as complexas atitudes das mulheres com AN frente aos seus corpos remetem à forma como elas lidam com sua sexualidade, aceitando-a ou recusando-a. A imagem corporal desempenha papel crucial nas atitudes frente às relações sexuais e, portanto, não é surpreendente que mulheres com AN apresentem dificuldades para se expressarem sexualmente, ou mesmo para desenvolverem relacionamentos íntimos, mantendo-se isoladas, ansiosas e emocionalmente retraídas. Temas como abuso sexual, capacidade de lidar com eventos estressores, perfeccionismo, padrões familiares, atitudes psicossexuais, entre outros, também foram discutidos pelos autores. Concluiu-se que a AN pode ser considerada um quadro psicopatológico multidimensional, caracterizado por uma variedade de transtornos orgânicos, psicodinâmicos e endocrinológicos. É impossível diferenciar os diferentes papéis desempenhados pelas alterações endocrinológicas e pelos comportamentos disfuncionais na promoção e/ou manutenção dos sintomas psicológicos e orgânicos. Muitos dos sintomas (especialmente as atitudes sexuais) fazem parte dos comportamentos típicos da AN ou são secundários à perda de peso e à depressão.

Com objetivo semelhante ao da pesquisa de Ghizzani e Montomoli (2000), o estudo de Romejko-Borowiec (2004) também investigou o desenvolvimento sexual de mulheres com 
TAs. Os autores realizaram uma vasta revisão da literatura científica acerca do tema, além de um estudo empírico no qual avaliaram 73 mulheres jovens e adultas com TAs, comparando-as com 31 mulheres sem condições clínicas. Os resultados corroboraram a literatura no que concerne à relação entre TAs e disfunção sexual. Os sintomas de TAs parecem estar relacionados com a adequação às normas impostas pela tradição cultural em relação aos papéis femininos, sendo considerados meios inconscientes de resolução de conflitos de identidade sexual. Os autores consideram que, ao desenvolver um transtorno desse tipo, as mulheres podem evitar e/ou prorrogar a necessidade de confrontar-se com os papéis exigidos das mulheres adultas.

Ruuska, Kaltiala-Heino, Koivisto e Rantanen (2003) realizaram um estudo que teve como objetivo avaliar possíveis relações entre TAs, puberdade e atitudes frente à sexualidade em uma amostra de 57 adolescentes do sexo feminino com AN e BN. Adolescentes com BN apresentavam ocorrência da menarca - que marca a entrada na puberdade e, portanto, o início das vivências relativas à sexualidade, etapa em que a menina deve se adaptar às mudanças no corpo e às novas demandas da maturidade sexual (Ruuska et al., 2003) - em idades mais precoces do que as observadas em adolescentes com AN e/ou sem TAs. No que concerne às atitudes frente à sexualidade, as adolescentes com AN apresentavam atitudes mais negativas do que aquelas diagnosticadas com BN, além de também apresentarem menor número de relacionamentos afetivos e interesse em namoro. Os autores realizaram o controle das variáveis referentes à idade das participantes, à idade da ocorrência da menarca e ao tempo de duração do TA, e ainda assim as atitudes negativas frente à sexualidade e ausência de relacionamentos afetivos encontravam-se mais relacionadas à $\mathrm{AN}$ do que à BN. De forma geral, os resultados sugerem que adolescentes com AN e BN apresentam diferentes formas de lidar com os desafios relacionados ao desenvolvimento sexual típicos da adolescência.

Capitaine, Rodgers e Chabrol (2011) partiram dos pressupostos da teoria da objetificação sexual para explorar a relação entre satisfação sexual, sintomas depressivos e problemas alimentares entre jovens universitárias com idades entre 18 e 28 anos. Segundo a teoria mencionada, o indivíduo vítima da objetificação sexual é tratado como uma coleção de partes de um corpo reduzido a um processo de erogeneização perversa, o que possibilita compreender as reverberações das relações sexuais indesejadas, propondo que a vitimização sexual é um aspecto da própria objetificação. Os resultados indicaram que experiências sexuais indesejadas estavam relacionadas a padrões alimentares disfuncionais e que os sintomas depressivos eram fatores mediadores de tal relação. Experiências sexuais negativas podem exercer impacto sobre a imagem corporal, levando à vivência de emoções negativas 
em relação à feminilidade e à sexualidade que, por sua vez, podem precipitar o comportamento disfuncional de restrição alimentar.

Ainda em relação às experiências sexuais indesejadas, o estudo de Castellini et al. (2013) teve por objetivo avaliar o curso longitudinal do funcionamento sexual, assim como a relação entre mudanças observadas na psicopatologia e história de abuso na infância com o funcionamento sexual em pacientes com AN e BN. Participaram da pesquisa 27 mulheres com AN e 31 com BN, que foram submetidas a um ano de tratamento com Terapia CognitivoComportamental (TCC), tendo sido avaliadas no início e ao final do tratamento. A avaliação indicou que as pacientes apresentaram melhora significativa em todos os domínios do funcionamento sexual, exceto aquelas que tinham histórico de abuso sexual. A redução da gravidade dos TAs estava diretamente associada à melhora do funcionamento sexual, novamente com a exceção das participantes com histórico de abuso sexual. Concluiu-se que as psicopatologias alimentares podem ser consideradas fatores de manutenção da disfunção sexual em indivíduos acometidos por TAs. Indivíduos com histórico de abuso sexual representam uma subpopulação de pacientes com profundo mal-estar envolvendo a percepção corporal e o funcionamento sexual. Esse mal-estar parece não ter sido adequadamente abordado durante a intervenção de TCC. Porém, os autores ressaltam que os resultados devem ser considerados preliminares, dado o pequeno número de participantes da amostra do estudo.

Collins, Fischer, Stojek e Becker (2014) desenvolveram um estudo no qual buscaram verificar de que modo a supressão de pensamento após a ocorrência de abuso sexual ou tentativa de abuso poderiam resultar no aumento de sintomas alimentares no início da vida adulta. Supressão de pensamento pode ser definida como estratégia utilizada para a regulação da emoção, e envolve tentativas de remover pensamentos indesejados da consciência. Trata-se de uma das formas mais eficazes de lidar com dificuldades emocionais decorrentes de traumas (Collins et al, 2014). Ao avaliar 319 universitárias, com idade média de 18 anos, os autores observaram que, ao suprimir pensamentos relacionados à vivência de abuso sexual recente (ou tentativa de abuso), as participantes apresentavam aumento dos sintomas de TAs. Foram controladas as seguintes variáveis: comportamentos alimentares disfuncionais anteriores ao abuso, e experiência de abuso sexual na infância. Concluiu-se, portanto, que ao suprimir os pensamentos relacionados ao abuso, as angústias resultantes da experiência traumática eram direcionadas para a alimentação, aumentando a ocorrência de sintomas disfuncionais e a probabilidade da precipitação de um quadro clínico de TA.

Por fim, apenas um artigo selecionado nesta revisão teve como objetivo explorar a relação entre TAs e sexualidade a partir da ótica de profissionais especializados no tratamento 
de pacientes com esses quadros (Eddy, Novotny, \& Westen, 2004). Os autores buscaram enfatizar as diferenças entre traços de personalidade de mulheres com AN e BN, hipotetizando que tais distinções poderiam estar relacionadas a comportamentos e atitudes frente à sexualidade. Dentre os 234 profissionais que participaram do estudo, 4/5 eram psicólogos e 1/5 eram psiquiatras. Os resultados sugerem que as relações entre TAs e sexualidade são complexas. Baixo peso corporal e histórico de sintomas anoréxicos podem estar associados com comportamentos infantilizados e sexualidade contida, enquanto que alta frequência de purgação e compulsão alimentar, além de histórico familiar de sintomas bulímicos, podem estar relacionados à sexualidade sedutora e, muitas vezes, destrutiva. Em termos de personalidade, os profissionais relataram que pacientes emocionalmente constritos, inibidos e supercontrolados, que tendem a restringir a alimentação e não têm consciência interoceptiva de sensações de fome, apresentam comportamentos sexuais restritivos bastante similares à restrição alimentar. Da mesma forma, pacientes emocionalmente descontrolados e desorganizados, que tendem a apresentar compulsão alimentar e purgação, manifestam comportamentos sexuais impulsivos e autodestrutivos, no que se assemelham às suas atitudes alimentares.

\section{Configurações socioculturais do feminino e os sintomas de TAs}

Esta categoria engloba quatro estudos que, de modo geral, abordaram a questão da feminilidade como construção sociocultural, buscando articulá-la com o desenvolvimento dos TAs. Um dos estudos recuperados (Hoskins, 2002) consistiu em uma exploração da formação da identidade feminina, criticando a permanência ortodoxa das teorias psicanalíticas clássicas do self, não obstante as teorias pós-modernas terem desafiado as formulações antigas ao dar ênfase à importância dos processos de autocriação em relação à cultura ou discurso. Na concepção pós-estruturalista, a sexualidade é pensada como uma multiplicidade de combinações que não surgem a partir da imposição psicossocial. Critica-se a concepção essencialista de uma identidade fixa e congelada, presente em teorias que lançam um olhar estereotipado sobre os indivíduos que manifestam sexualidades desviantes da condição normativa. Apesar dos inúmeros estudos acerca dos TAs que têm sido desenvolvidos nos últimos anos, a autora pontua que muito tem sido trabalhado em termos de psicopatologias individuais, negligenciando a compreensão das vivências das jovens como membros ativos da sociedade contemporânea, com todas as suas exigências para que as mulheres sejam belas, magras e bem-sucedidas. Ou seja, é preciso compreender de que forma a cultura influencia a vida de adolescentes do sexo feminino, considerando-se que os TAs afetam aspectos centrais 
do desenvolvimento da identidade. Dentre as diversas realidades pós-modernas que podem afetar a formação da identidade, a autora menciona: a forma como a sexualidade é retratada pelos programas de televisão, o aumento espantoso do número de cirurgias plásticas e a facilidade atual para modificar o corpo, bem como a exposição a novas construções de si e da realidade a partir do uso da internet; entre outros. Sugere-se a utilização de novas teorias do self na pesquisa e na prática, de forma a ampliar a compreensão dos profissionais de saúde a respeito do modo com as identidades são constituídas nas sociedades pós-modernas.

Ainda considerando a questão da construção da identidade enquanto fenômeno psíquico e sociocultural, Heenan (2005) defende a abordagem psicanalítica feminista, adaptada do livro Fat Is a Feminine Issue, de Susie Orbach (1978), no qual os distúrbios da alimentação são relacionados ao modo como as mulheres vivenciam a própria feminilidade, sendo que tais vivências, quando se tornam intoleráveis para o psiquismo, são cindidas e projetadas em nível do corpo. Heenan conduziu um estudo exploratório e descritivo, que teve como objetivo explorar o material clínico derivado de um grupo de terapia psicodinâmica feminista para mulheres com diversos problemas alimentares, buscando entrelaçar tanto os conteúdos discursivos quanto os inconscientes, para compreender a função do peso corporal para o gênero feminino. O estudo de Heenan se aproxima da pesquisa de Hoskins (2002), na medida em que trabalha com o conceito de corpo como interface entre a mente consciente e inconsciente, inserida em um mundo tanto interno quanto externo (social).

Heenan (2005) sugere que, para muitas mulheres, é comum buscar a felicidade simbólica que a dieta e o corpo esbelto supostamente ofereceriam, ou seja, atualmente, as mulheres crescem em um meio sociocultural no qual a felicidade e o bem-estar são equiparados ao fato de serem magras. Apesar das melhoras trazidas pela abordagem psicanalítica feminista, a autora finaliza o estudo afirmando que possibilitar a construção de uma relação satisfatória de mulheres com TAs com seus próprios corpos é uma tarefa extremamente desafiadora. Para que essa relação satisfatória possa ser um dia conquistada, as terapias deveriam ser combinadas com abordagens cognitivo-comportamentais.

Woolhouse, Day, Rickett e Milnes (2012) desenvolveram um estudo com enfoque qualitativo de pesquisa, que teve como objetivo investigar discursos de jovens mulheres acerca dos temas: comida, alimentação, feminilidades, corpo e incorporação de papéis sociais tradicionalmente femininos. Participaram do estudo 37 adolescentes de escolas de ensino médio e jovens adultas de uma universidade do Reino Unido. Os resultados indicaram que significados culturais dominantes sobre corpo, tamanho, forma, comida e alimentação foram frequentemente reproduzidos pelos discursos das participantes. Corpos magros foram 
retratados como símbolo de sucesso social, econômico e cultural. Restrição e abnegação indicavam controle, autodisciplina e virtude moral; gordura foi considerada marca de desvio, ausência de autodisciplina e algo a "ser queimado" e expurgado; alimentação foi significada como fonte de culpa e vergonha, e comida foi equiparada a algo pecaminoso e um inimigo a ser derrotado. No entanto, as participantes também puderam criar espaços discursivos alternativos para romper e desafiar significados culturalmente dominantes. De forma geral, evidenciou-se que os atos de comer com restrição e fazer dieta eram decorrentes, principalmente, de discursos neoliberais, mais do que de escolhas individuais. Portanto, uma estratégia encontrada para retirar-se da posição subjetiva de "garota feminina" ("girly girl”) foi forjar suas próprias práticas femininas enquanto escolhas próprias.

Por fim, no estudo de Green, Davids, Skaggs, Riopel, e Hallengren (2008), a questão sociocultural como fator de influência sobre a insatisfação corporal feminina foi abordada a partir do exame da conformidade de jovens universitárias, com idades entre 17 e 23 anos, com as normas culturais tradicionais que regem as atitudes e comportamentos tipicamente femininos. Os autores sugerem que mulheres em risco para desenvolvimento de TAs endossam os papéis de gênero tradicionalmente atribuídos às mulheres, tais como dependência e passividade, e apresentam exacerbada necessidade de aprovação social. Os resultados do estudo de Green et al. (2008) indicaram que a valorização da magreza configura o fator mais importante no que diz respeito à relação entre a alta conformidade com as normas tradicionais de gênero e altos índices de sintomas de TAs. Outras normas típicas do gênero feminino não foram relacionadas à sintomatologia de TAs, portanto, não foi possível concluir que todos os aspectos da feminilidade podem atuar como fatores de risco para a precipitação desses quadros psicopatológicos. No entanto, vale ressaltar que a feminilidade é um construto multidimensional, que não deve ser reduzido apenas à relação satisfatória ou insatisfatória com o corpo. É preciso entender que a vivência corporal remete a um sintoma de uma experiência mais profunda consigo mesma, com o devir da sexualidade, com o ser mulher e todas as vicissitudes envolvidas.

\section{Puberdade e atividade sexual}

Foram selecionados apenas dois estudos que abordaram questões acerca do desenvolvimento da sexualidade e atividades sexuais em mulheres acometidas por TAs. Kaltiala-Heino, Rimpelä, Rissanen e Rantanen (2001) buscaram examinar a associação entre puberdade precoce, desenvolvimento sexual prematuro e psicopatologias alimentares do tipo bulímico - ou seja, distúrbios caracterizados por compulsão e purgação alimentares, mas que 
não haviam sido diagnosticados como BN por não se tratar de uma amostra clínica - em adolescentes entre 14 e 16 anos, de ambos os sexos. A amostra consistiu em 19321 adolescentes do sexo masculino e 19196 do sexo feminino, recrutados em 258 escolas finlandesas. Os resultados indicaram que as adolescentes que apresentavam sintomas bulímicos também tiveram menarca precoce e experiências sexuais prematuras. Dentre os adolescentes do sexo masculino, o início das ejaculações na idade normativa foi considerado fator de proteção contra a ocorrência de traços bulímicos, e o risco foi considerado elevado para aqueles que apresentavam início precoce ou tardio. Conclui-se que, para que se possa desenvolver práticas preventivas para TAs e intervenções precoces, deve-se voltar a atenção para adolescentes com maturação precoce (no caso das meninas) e/ou tardia (no caso dos meninos), assim como para o início prematuro das atividades sexuais.

O segundo estudo inserido nesta categoria, desenvolvido por Pinheiro et al. (2010), teve por objetivo descrever o funcionamento sexual de mulheres com TAs, levando-se em consideração a escassez de literatura científica disponível acerca dos problemas de intimidade e funcionamento sexual apresentados por mulheres acometidas por TAs. Dentre as 242 mulheres avaliadas, 98\% informaram já ter experimentado relacionamentos íntimos, sendo que em 55\% desses relacionamentos houve relação sexual; 87\% da amostra referiram ter tido relacionamentos significativos com diversos níveis de estabilidade ao longo da vida. Aproximadamente $60 \%$ das participantes com TAs referiram perda da libido e ansiedade relacionada à sexualidade. Mulheres com AN demonstraram maior prevalência de perda da libido do que mulheres com BN e TA não-especificado. Ausência de relações sexuais foi associada com baixo índice de massa corporal (IMC) ao longo da vida e ocorrência precoce do TA; perda da libido foi associada com baixo IMC, altos níveis de consciência interoceptiva e traços de ansiedade; e ansiedade sexual foi associada a baixo IMC, condutas de evitação de danos e ineficácia. A incidência de disfunções sexuais nas mulheres com TAs foi maior do que na amostra normativa. Os autores concluíram que a intimidade sexual se refere a um aspecto fundamental dos relacionamentos saudáveis e pode ser rompida pela ocorrência de um TA. Portanto, deve ser frequentemente avaliada pela equipe de saúde, juntamente com outras esferas mais comumente avaliadas e valorizadas pelos profissionais, tais como o comportamento social e ocupacional, a prática de exercícios físicos, os hábitos alimentares, entre outras. 


\section{TAs e relação mãe-filha}

$\mathrm{Na}$ interface sexualidade e cuidado parental foi selecionado apenas um estudo (Lane, 2002), de caráter exploratório e descritivo, que teve como objetivo apresentar uma reflexão teórica psicanalítica acerca da AN e sua relação com outros problemas de autoagressão, tais como masoquismo e automutilação. O autor parte da psicanálise, que considera que a AN origina-se na relação precoce da criança com a mãe, que resulta em dificuldades na separação psicológica da dupla e no desenvolvimento de um self autônomo. A jovem mulher passa a se autoagredir como forma de expressar conflitos internos no corpo, tanto de forma simbólica quanto como uma forma de descarregar tensões e se autoconfortar, direcionar a dor mental para o corpo, autopurificar-se dos impulsos corporais, ou como forma passivo-agressiva de vingar-se das figuras parentais.

De modo geral, o autor sugere que tanto indivíduos com TAs quanto autoagressores provêm de famílias disfuncionais, com mães altamente controladoras, pais (genitores do sexo masculino) ausentes e um histórico de eventos traumáticos. São pacientes depressivas e obsessivas, excessivamente apegadas às mães, que por sua vez desencorajam suas tentativas de emancipação. Os sintomas teriam a função inconsciente de manter as mulheres em posição infantilizada, com sentimentos negativos frente à menstruação, maturidade sexual, desenvolvimento corporal e feminilidade em geral. Tais sintomas englobam comportamentos autodestrutivos, que teriam como objetivo remover pensamentos sobre sexo, tentações e atividades eróticas. Tanto os TAs quanto as automutilações configuram formas deliberadas de autoagressão, que funcionam como forma de catarse, "purificando" a jovem e, ao mesmo tempo, modulando estados dissociados de ansiedade, tensão sexual, raiva e sensação de vazio, despertando sentimento de alívio, descrito como “quase físico" (Lane, 2002). Nesse sentido, as pacientes fazem uso de substitutos que previnem a maturação e o desenvolvimento da feminilidade, fazendo com que a jovem regrida a fases pré-genitais do desenvolvimento psicossexual, com uso abundante de defesas típicas desse estágio. Essa regressão a distancia por um tempo da responsabilidade de responder às demandas da puberdade e da maturidade sexual.

\section{Considerações Finais}

A presente revisão integrativa da literatura teve como objetivo sintetizar a produção científica nacional e internacional acerca do tema da sexualidade feminina no contexto dos TAs. A maioria dos estudos selecionados apresentava delineamento metodológico não experimental, com enfoque descritivo e correlacional $(n=8)$, seguidos de estudos qualitativos 
com enfoque exploratório e descritivo $(n=6)$, sendo que apenas um dos estudos qualitativos envolvia investigação empírica, enquanto que os outros cinco traziam sínteses da literatura disponível acerca do tema. Em termos de hierarquia de evidências, a maioria dos estudos foi classificada como NE 4, que indica a utilização de métodos pouco robustos na realização da pesquisa.

Exceto pelos estudos de reflexão teórica, todos os artigos selecionados nesta revisão possuíam amostras amplas, variando entre 37 e 38517 participantes (incluindo todos os grupos de comparação). Os instrumentos utilizados eram, em sua grande maioria, padronizados e com importantes propriedades psicométricas. Assim, acredita-se que há grande possibilidade de generalização dos resultados encontrados pela grande maioria dos estudos selecionados, indicando significativa contribuição para a literatura científica na área abordada. No entanto, a maioria dos estudos selecionados apresenta uma importante limitação: dos 21, apenas sete incluíram em suas amostras indivíduos com diagnóstico de TA preestabelecido, o que pode prejudicar a aplicação dos resultados em intervenções clínicas, uma vez que o funcionamento psicodinâmico e comportamental de pacientes com esses quadros difere do funcionamento de pessoas sem tais psicopatologias, ainda que essas pessoas configurem população de risco e que apresentem comportamentos alimentares disfuncionais e insatisfação com a imagem corporal. Evidencia-se, portanto, a necessidade de estudos com pacientes com diagnóstico de TA preestabelecido por equipe multidisciplinar, de modo que os resultados possam dar subsídios para o aprimoramento da assistência à saúde dessa população.

Retomando a questão de pesquisa que norteou este estudo, percebeu-se que a sexualidade e a feminilidade se articulam de diferentes formas com o desenvolvimento e a manutenção dos sintomas de TAs. Os estudos selecionados buscaram diferenciar as experiências de mulheres com $\mathrm{AN}$ e $\mathrm{BN}$ no que diz respeito à realização de atividades sexuais, idade da menarca, vivência ou ausência de relacionamentos afetivos, atitudes frente à sexualidade, entre outros aspectos colocados em relevo. Evidenciou-se, de modo geral, que a AN está relacionada a atitudes negativas frente à sexualidade, baixa frequência de atividades sexuais e evitação de relacionamentos afetivos, ao passo que a BN está associada à menarca precoce, início prematuro da atividade sexual, com frequência acompanhada de abuso e tendência à promiscuidade sexual.

A feminilidade foi considerada fator de risco para o desenvolvimento de TAs, pois estava associada a altos índices de comportamentos alimentares restritivos, enquanto que a masculinidade foi considerada fator de proteção. Ao abordarem a questão das normas 
socioculturais femininas e sua relação com a precipitação de TAs, alguns autores concluíram que as mulheres que desenvolvem esses quadros apresentam maior propensão a serem femininas, infantis, temperamentais, ambiciosas, desejosas de receberem elogios e de galgarem uma posição social elevada. Em contrapartida, as mulheres sem TAs foram consideradas mais felizes consigo mesmas, confiantes, compreensivas, independentes, autossuficientes e capazes de tomar decisões. Nesse sentido, é possível concluir que a feminilidade configura o principal traço da identidade de gênero em mulheres com TAs.

A dieta e o corpo esbelto representam uma felicidade imaginária endossada pelo meio sociocultural. Os papéis de gênero tradicionalmente atribuídos ao feminino incluem a valorização da magreza como sinônimo absoluto de felicidade e bem-estar. No entanto, notam-se lacunas na literatura no que concerne ao trabalho com o significado subjetivo da experiência da sexualidade e da vivência do feminino para mulheres acometidas por TAs. As investigações analisadas nesta revisão apresentam evidências de que há dificuldades específicas, por parte das mulheres com $\mathrm{AN}$ e $\mathrm{BN}$, frente à sexualidade. No entanto, não foram encontrados estudos que fornecessem espaço para que essas mulheres pudessem expressar suas percepções, representações, sensações e sentimentos a respeito de suas experiências sexuais e afetivas.

Os estudos que se propõem a examinar aspectos que envolvem a constituição subjetiva e o desejo sexual são de natureza eminentemente teórica, basicamente na vertente psicanalítica, o que gera uma limitação importante no alcance de suas propostas uma vez que prescindem de validação empírica dos pressupostos teóricos que defendem. Por conseguinte, não foram detectadas evidências empíricas que deem sustentação a uma teorização acerca dos aspectos subjetivos e fenomenológicos da vivência da sexualidade e da feminilidade por pacientes diagnosticadas com TAs. Esses dados evidenciam a necessidade de estudos que investiguem empiricamente a questão da sexualidade feminina no contexto dos TAs, buscando articular a teoria psicanalítica com vivências narradas por pacientes.

\section{Referências}

Akobeng, A. K. (2005). Principles of evidence based medicine. Archives of Disease in Childhood, 90(8), 837-840.

Behar, R., Barrera, M., \& Michelotti, J. (2003). Características clínicas e identidad genérica en subtipos de trastornos de la conducta alimentaria. Revista Médica do Chile, 131(7), 748758.

Beyea, S. C., \& Nicoll, L. H. (1998). Writing in integrative review. AORN Journal, 67(4), 877-880. 
Broome, M. E. (2000). Integrative literature reviews for the development of concepts. In B. L. Rodgers \& K. A. Knafl (Eds.), Concept development in nursing ( $2^{\mathrm{a}}$ ed., pp. 231-250). Philadelphia, PA: Saunders.

Capitaine, M., Rodgers, R. F., \& Chabrol, H. (2011). Unwanted sexual experiences, depressive symptoms and disordered eating among college students. Eating Behaviors, 12(1), 86-89.

Castellini, G., Lo Sauro, C., Lelli, L., Godini, L., Vignozzi, L., Rellini, A. H., Faravelli, C., Maggi, M., \& Ricca, V. (2013). Childhood sexual abuse moderates the relationship between sexual functioning and eating disorder psychopathology in anorexia nervosa and bulimia nervosa: A 1-year follow-up study. Journal of Sexual Medicine, 10(9), 2190-2200.

Cella, S., Iannaccone, M., \& Cotrufo, P. (2013). Influence of gender role orientation (masculinity versus femininity) on body satisfaction and eating attitudes in homosexuals, heterosexuals and transsexuals. Eating and Weight Disorders, 15(2), 115-124.

Eddy, K. T., Novotny, C. M., \& Westen, D. (2004). Sexuality, personality and eating disorders. Eating Disorders, 12(3), 191-208.

Fernandes, L. M. (2000). Úlcera de pressão em pacientes críticos hospitalizados: Uma revisão integrativa da literatura. Dissertação de Mestrado, Universidade de São Paulo, Ribeirão Preto, SP.

Galvão, C. M., Sawada, N. O., \& Mendes, I. A. C. (2003). A busca das melhores evidências. Revista da Escola de Enfermagem da USP, 37(4), 43-50.

Ghizzani, A. \& Montomoli, M. (2002). Anorexia nervosa and sexuality in women: A review. Journal of Sex Education and Therapy, 25(1), 80-88.

Green, M. A., Davids, C. M., Skaggs, A. K., Riopel, C. M., \& Hallengren, J. J. (2008). Femininity and eating disorders. Eating Disorders, 16(4), 283-293.

Heenan, C. (2005). A feminist psychotherapeutic approach to working with women who eat compulsively. Counselling and Psychotherapy Research, 5(3), 238-245.

Hepp, U., Spindler, A., \& Milos, G. (2005). Eating disorder symptomatology and gender role orientation. International Journal of Eating Disorders, 37(3), 227-233.

Hoskins, M. L. (2002). Girl's identity dilemas: Spaces defined by definitions of worth. Health Care for Women International, 23(3), 231-247.

Hughes, R. G. (2008). Patient safety and quality: An evidence-based handbook for nurses. AHRQ Publication $\mathrm{n}^{\circ}$ 08-0043. Rockville, MD: Agency for Healthcare Research and Quality.

Januszek, K. (2007). Some aspects of sexual identity of girls suffering from anorexia nervosa. Archives of Psychiatry and Psychotherapy, 9(3), 53-62.

Kaltiala-Heino, R., Rimpelä, M., Rissanen, A., \& Rantanen, P. (2001). Early puberty and early sexual activity are associated with bulimic-type eating pathology in middle adolescence. Journal of Adolescent Health, 28(4), 346-352.

Lane, R. C. (2002). Anorexia, masochism, self-mutilation, and autoerotism: The spider mother. Psychoanalitic Review, 89(1), 101-123.

Leonidas, C. \& Santos, M. A. (2014). Social support networks and eating disorders: An integrative review of the literature. Neuropsychiatric Disease and Treatment, 10, 915-927.

Machado, V., Leonidas, C., \& Santos, M. A. (2012). Psychiatric readmission: An integrative review of the literature. International Nursing Review, 59(4), 447-457.

Meyer, C., Blisset, J., \& Oldfield, C. (2001). Sexual orientation and eating psychopathology: The role of masculinity and femininity. International Journal of Eating Disorders, 29(3), 314-318.

Moher D., Liberati A., Tetzlaff J., \& Altman D. G. The PRISMA Group. (2009). Preferred reporting items for systematic reviews and meta-analyses: The PRISMA statement. Annals of Internal Medicine, 151(4), 221-296. 
Moore, F. \& Keel, P. K. (2003). Influence of sexual orientation and age on disordered eating attitudes and behaviors in women. International Journal of Eating Disorders, 34(3), 370374.

Pai, M., McCulloch, M., Gorman, J. D., Pai, N., Enanoria, W., Kennedy, G., Tharyan, P., \& Colford Jr, J. M.. (2004). Systematic reviews and meta-analyses: an illustrated, step-bystep guide. National Medical Journal of India, 17(2), 86-95.

Pinheiro, A. P., Raney, T. J., Thornton, L. M., Fichter, M. M., Berretini, W. H., Goldman, D., Halmi, K. A., Kaplan, A. S., Strober, M., Treasure, J., Woodside, D. B., Kaye, W. H., \& Bulik, C. M. (2010). Sexual functioning in women with eating disorders. International Journal of Eating Disorders, 43(2), 123-129.

Romejko-Borowiec, A. (2004). Eating disorders as a specific method of solving the sexual identity crisis. Archives of Psychiatry and Psychotherapy, 6(4), 41-48.

Ruuska, J., Kaltiala-Heino, R., Koivisto, A. M., \& Rantanen, P. (2003). Puberty, sexual development and eating disorders in adolescente outpatients. European Child \& Adolescent Psychiatry, 12(5), 214-220.

Santos, C. M. C., Pimenta, C. A. M., \& Nobre, M. R. C. (2007). The PICO strategy for the research question construction and evidence search. Revista Latino-Americana de Enfermagem, 15(3): 508-511.

Scorsolini-Comin, F., \& Santos, M. A. (2010). The scientific study of happiness and health promotion : An integrative literature review. Revista Latino-Americana de Enfermagem, 18(3), 471-479.

Scorsolini-Comin, F. \& Santos, M. A. (2010). Psicologia positiva e os instrumentos de avaliação no contexto brasileiro. Psicologia: Reflexão e Crítica, 23(3), 440-448.

Simoni, J. M. \& Bastos, A. (2013). Quando a anorexia é uma questão de sexuação. Arquivos Brasileiros de Psicologia, 65(3), 409-420.

Sousa, V. D., Driessnack, M., \& Mendes, I. A. C. (2007). Revisão dos desenhos de pesquisa relevantes para enfermagem. Parte 1: Desenhos de pesquisa quantitativa. Revista LatinoAmericana de Enfermagem, 15(3), 502-507.

Stillwell, S. B., Fineout-Overholt, E., Melnyk, B. M., \& Williamson, K. M. (2010). Evidencebased practice, step by step: Asking the clinical question: A Key step in evidence-based practice. The American Journal of Nursing, 110(3), 58-61.

Veit, C. M. \& Castro, E. K. (2013). Coping religioso/espiritual e câncer de mama: Uma revisão sistemática da literatura. Psicologia, Saúde e Doenças, 14(1), 1-22.

Whittemore, R., \& Knafl, K. (2005). The integrative review: updated methodology. Journal of Advanced Nursing, 52(5), 546-553.

Woolhouse, M., Day, K., Rickett, B., \& Milnes, K. (2012). “Cos girls aren't supposed to eat like pigs are they?” Young women negotiating gendered discursive constructions of food and eating. Journal of Health Psychology, 17(1), 46-56.

Yean, C., Benau, E. M., Dakanalis, A., Hormes, J. M., Perone, J., \& Timko C. A. (2013). The relationship of sex and sexual orientation on self-esteem, body shape satisfaction, and eating disorder symptomatology. Frontiers in Psychology, 4. doi: 10.3389/fpsyg.2013.00887 


\section{Anexo II. Autorização formal do coordenador do GRATA para realização da pesquisa}

UNIVERSIDADE DE SÃO PAULO

FACULDADE DE FILOSOFIA, CIÊNCIAS E LETRAS DE RIBEIRÃO PRETO

DEPARTAMENTO DE PSICOLOGIA E EDUCAÇ̃̃O

NEPPS - Núcleo de Ensino e Pesquisa em Psicologia da Saúde

Av. Bandeirantes, 3900 - Monte Alegre - 14040-901 - Ribeirão Preto - SP

Fone (0xx 16) $36023645-81329896$

\section{DECLARAÇÃO}

Declaro, para os devidos fins, que estou ciente e de acordo com o desenvolvimento do projeto de pesquisa, nível de Doutorado, intitulado "Das (im)possibilidades do feminino: A sexualidade de mulheres com transtornos alimentares", a ser desenvolvido pela estudante Carolina Leonidas, sob a orientação do Prof. Dr. Manoel Antônio dos Santos, docente do departamento de Psicologia e Educação da FFCLRP-USP.

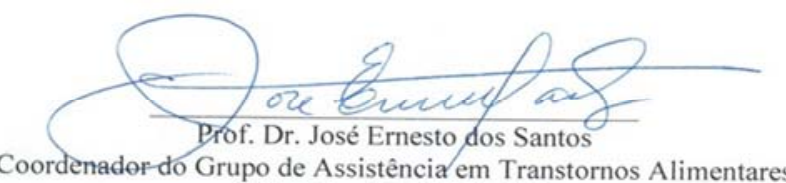
GRATA - HCFMRP-USP 
Anexo III. Critério de Classificação Econômica Brasil 2015
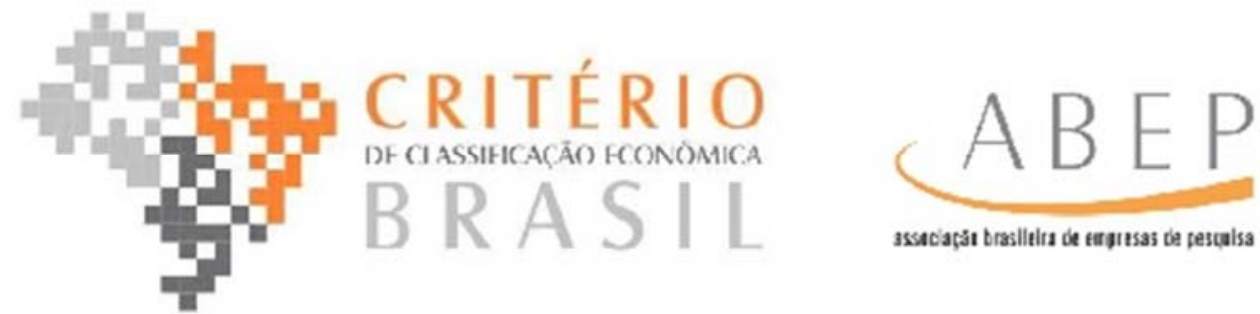

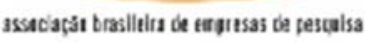

Alterações na aplicação do Critério Brasil, válidas a partir de 01/01/2015

A metodologia de desenvolvimento do Critério Brasil que entra em vigor no inicio de 2015 está descrita no livro Estratificação Socioeconômica e Consumo no Brasil dos professores Wagner Kamakura (Rice University) e José Afonso Mazzon (FEA /USP), baseado na Pesquisa de Orçamento Familiar (POF) do IBGE.

A regra operacional para classificação de domicilios, descrita a seguir, resulta da adaptação da metodologia apresentada no livro às condições operacionais da pesquisa de mercado no Brasil.

As organizações que utilizam o Critério Brasil podem relatar suas experiências ao Comitê do CCEB. Essas experiências serão valiosas para que o Critério Brasil seja permanentemente aprimorado.

A transformação operada atualmente no Critério Brasil foi possivel graças a generosa contribuição e intensa participação dos seguintes profissionais nas atividades do comitê:

Luis Pilli (Coordenador) - LARC Pesquisa de Marketing

Bianca Ambrósio -TNS

Bruna Suzzara - IBOPE

Marcelo Alves - Nielsen

Margareth Reis - GFK

Paula Yamakawa - IBOPE

Renata Nunes - Data Folha

Tatiana Wakaguri - IBOPE

Sandra Mazzo - IPSOS

Valéria Tassari - IPSOS

A ABEP, em nome de seus associados, registra o reconhecimento e agradece o envolvimento desses profissionais. 


\section{SISTEMA DE PONTOS}

\section{Variáveis}

\begin{tabular}{|c|c|c|c|c|c|}
\hline & \multicolumn{5}{|c|}{ Quantidade } \\
\hline & 0 & 1 & 2 & 3 & $40 u+$ \\
\hline Banheiros & 0 & 3 & 7 & 10 & 14 \\
\hline Empregados domésticos & 0 & 3 & 7 & 10 & 13 \\
\hline Automóveis & 0 & 3 & 5 & 8 & 11 \\
\hline Microcomputador & 0 & 3 & 6 & 8 & 11 \\
\hline Lava louca & 0 & 3 & 6 & 6 & 6 \\
\hline Geladeira & 0 & 2 & 3 & 5 & 5 \\
\hline Freezer & 0 & 2 & 4 & 6 & 6 \\
\hline Lava roupa & 0 & 2 & 4 & 6 & 6 \\
\hline DVD & 0 & 1 & 3 & 4 & 6 \\
\hline Micro-ondas & 0 & 2 & 4 & 4 & 4 \\
\hline Motocicleta & 0 & 1 & 3 & 3 & 3 \\
\hline Secadora roupa & 0 & 2 & 2 & 2 & 2 \\
\hline
\end{tabular}

\section{Grande instrucão do chefe de familia eacesso a servicos públices}

\begin{tabular}{|c|c|}
\hline \multicolumn{2}{|l|}{ Escolaridade da pessoa de referência } \\
\hline Analfabeto / Fundamental I incompleto & 0 \\
\hline Fundamental I completo / Fundamental II incompleto & 1 \\
\hline Fundamental II completo / Médio incompleto & 2 \\
\hline Médio completo/Superior incompleto & 4 \\
\hline Superior completo & 7 \\
\hline \multicolumn{2}{|l|}{ Serviços pứblicos } \\
\hline Năo & Sim \\
\hline Água encanada & 4 \\
\hline Rua pavimentada & 2 \\
\hline
\end{tabular}

\section{Distribuicão das classes}

As estimativas do tamanho dos estratos atualizados referem-se ao total Brasil e resultados das Macro Regiöes, além do total das 9 Regiöes Metropolitanas e resultados para cada um das RM's (Porto Alegre, Curitiba, São Paulo, Rio de Janeiro, Belo Horizonte, Brasília, Salvador, Recife e Fortaleza).

As estimativas para o total do Brasil e Macro Regiões são baseadas em estudos probabilisticos nacionais do Datafolha e IBOPE Inteligência. E as estimativas para as 9 Regiöes Metropolitanas se baseiam em dados de estudos probabilisticos da GFK, IPSOS e IBOPE Media (LSE). 


\begin{tabular}{|c|c|c|c|c|c|c|c|c|c|c|}
\hline Classe & Brasil & Sudeste & Sul & Nordeste & $\begin{array}{l}\text { Centro } \\
\text { Oeste }\end{array}$ & Norte & & & & \\
\hline A & $2,7 \%$ & $3,3 \%$ & $3,2 \%$ & $1,1 \%$ & $3,7 \%$ & $1,5 \%$ & & & & \\
\hline B1 & $5,0 \%$ & $7,0 \%$ & $6,3 \%$ & $2,1 \%$ & $5,7 \%$ & $2,5 \%$ & & & & \\
\hline B2 & $18,1 \%$ & $22,7 \%$ & $21,3 \%$ & $10,2 \%$ & $20,3 \%$ & $11,2 \%$ & & & & \\
\hline C1 & $22,9 \%$ & $27,3 \%$ & $29,0 \%$ & $14,9 \%$ & $22,6 \%$ & $14,4 \%$ & & & & \\
\hline $\mathrm{C2}$ & $24,6 \%$ & $23,9 \%$ & $24,5 \%$ & $24,5 \%$ & $25,9 \%$ & $28,2 \%$ & & & & \\
\hline$D-E$ & $26,6 \%$ & $15,9 \%$ & $15,6 \%$ & $47,2 \%$ & $21,8 \%$ & $42,1 \%$ & & & & \\
\hline Classe & 9RM's & POA & CWB & SP & $\mathbf{R}$ & BH & BSB & SSA & REC & FOR \\
\hline A & $4,3 \%$ & $4,5 \%$ & $6,5 \%$ & $5,0 \%$ & $3,1 \%$ & $3,9 \%$ & $10,6 \%$ & $1,8 \%$ & $2,7 \%$ & $3,6 \%$ \\
\hline B1 & $6,6 \%$ & $7,2 \%$ & $9,2 \%$ & $8,1 \%$ & $5,2 \%$ & $5,8 \%$ & $11,3 \%$ & $3,5 \%$ & $4,0 \%$ & $4,4 \%$ \\
\hline B2 & $20,7 \%$ & $23,7 \%$ & $26,5 \%$ & $25,1 \%$ & $18,3 \%$ & $20,3 \%$ & $23,2 \%$ & $12,6 \%$ & $12,2 \%$ & $12,1 \%$ \\
\hline C1 & $25,0 \%$ & $28,4 \%$ & $27,1 \%$ & $27,9 \%$ & $24,3 \%$ & $24,7 \%$ & $22,2 \%$ & $21,1 \%$ & $18,6 \%$ & $16,7 \%$ \\
\hline C2 & $25,0 \%$ & $23,7 \%$ & $21,1 \%$ & $23,1 \%$ & $27,4 \%$ & $26,7 \%$ & $18,8 \%$ & $30,5 \%$ & $27,3 \%$ & $24,7 \%$ \\
\hline D-E & $18,4 \%$ & $12,5 \%$ & $9,6 \%$ & $10,9 \%$ & $21,7 \%$ & $18,5 \%$ & $13,9 \%$ & $30,5 \%$ & $35,1 \%$ & $38,5 \%$ \\
\hline
\end{tabular}

\section{Cortes de Critério Brasil}

\begin{tabular}{|c|c|}
\hline Classe & Pontos \\
\hline A & $45-100$ \\
\hline B1 & $38-44$ \\
\hline B2 & $29-37$ \\
\hline C1 & $23-28$ \\
\hline C2 & $17-22$ \\
\hline D-E & $0-16$ \\
\hline
\end{tabular}

\section{Estimativa para a Renda Média Domiciliar para os estratos do Critério Brasil}

Abaixo são apresentadas as estimativas de renda domiciliar mensal para os estratos sócioeconômicos. Os valores se baseiam na PNAD 2013 e representam aproximações dos valores que podem ser obtidos em amostras de pesquisas de mercado, mídia e opinião. A experiência mostra que a variância observada para as respostas à pergunta de renda é elevada, com sobreposições importantes nas rendas entre as classes. Isso significa que pergunta de renda não é um estimador eficiente de nivel sócio-econômico e não substitui ou complementa o questionário sugerido abaixo. $\mathrm{O}$ objetivo da divulgação dessas informações é oferecer uma ideia de caracteristica dos estratos sócio-econômicos resultantes da aplicação do Critério Brasil.

\begin{tabular}{|cc|}
\hline $\begin{array}{c}\text { Estrato Socio } \\
\text { Econômico }\end{array}$ & $\begin{array}{c}\text { Renda média } \\
\text { Domiciliar }\end{array}$ \\
\hline A & $20.272,56$ \\
\hline B1 & $8.695,88$ \\
\hline B2 & $4.427,36$ \\
\hline C1 & $2.409,01$ \\
\hline C2 & $1.446,24$ \\
\hline D -E & 639,78 \\
\hline TOTAL & $\mathbf{2 . 8 7 6 , 0 5}$ \\
\hline
\end{tabular}




\title{
Anexo IV. Carta de aceite do Comitê de Ética em Pesquisa FFCLRP-USP
}

\author{
Universidade de São Paulo
}

Faculdade de Filosofia, Ciências e Letras de Ribeirão Preto

Comitê de Ética em Pesquisa

Campus de Ribeirão Preto

Of.CEtP/FFCLRP-USP/027-jsI

Prezada Pesquisadora,

Comunicamos a V. Sa. que o projeto de pesquisa intitulado "DAS (IM)POSSIBILIDADES DO FEMININO: A SEXUALIDADE DE MULHERES COM TRANSTORNOS ALIMENTARES" foi reanalisado pelo Comitê de Ética em Pesquisa da FFCLRP-USP, em sua $119^{a}$ Reunião Ordinária, realizada em 25.04.2013, e enquadrado na categoria: APROVADO (CAAE n. $\left.{ }^{\circ} 11955112.4 .0000 .5407\right)$.

Solicitamos que eventuais modificaçōes ou emendas ao projeto de pesquisa sejam apresentadas ao CEP, de forma sucinta, identificando a parte do projeto a ser modificada e suas justificativas, e que, ao término do estudo, um relatório final seja entregue, via Plataforma Brasil.

Atenciosamente,

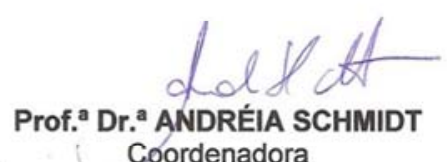

Coordenadora

\author{
A Senhora \\ Carolina Leonidas \\ Programa de Pós-graduação em Psicologia da FFCLRP USP \\ $c / c:$ \\ Prof. Dr. Manoel Antônio dos Santos \\ Departamento de Psicologia da FFCLRP USP \\ CEP - Comité de Etica em Pesquisa da FFCLRP \\ Fone: (16) 3602-4811 \\ Fax: (16) 3633-2660 (direto) ou 3633-5015 \\ Avenida Bandeirantes, 3900 - bloco 3 - sala 16 - 14040-901 - Ribeirăo Preto - SP - Brasil \\ Homepage: http://hwww.ffclirp usp. br - e-mail: coetp@ @ffclirp usp. br
}




\section{APÊNDICES}

\section{Apêndice I - Roteiro de Entrevista Semiestruturada}

\section{PACIENTES}

\section{Dados sociodemográficos:}

Nome:

Naturalidade: Procedência:

Idade: Nível de escolaridade:

Ocupação:

Situação conjugal: Filhos: ( ) sim

( ) não

Quantos:

Renda familiar:

$\mathrm{N}^{0}$ de pessoas que moram na residência:

Tipo de moradia (própria, alugada, emprestada):

Religião: Praticante: ( ) sim

( ) não Frequência semanal:

\section{Informações acerca do transtorno alimentar}

- Atualmente, quais são suas dificuldades com a alimentação?

- Desde quando você percebe que isso vem acontecendo? (Investigar se houve momentos de melhora ou de agravamento e que fatores a participante associa a esses momentos)

\section{Situação emocional da participante}

- Pensando nas suas emoções, depois que o transtorno alimentar começou, que sentimentos você passou a experimentar com mais freqüência? Como está hoje? (Investigar a que comportamentos esses sentimentos estão associados)

- Qual é a principal dificuldade que você passou a enfrentar após a instalação do quadro?

- O que faz para enfrentar suas dificuldades? O que ajuda a amenizar esses problemas? Em que situações essa ajuda traz bons resultados?

\section{Informações relativas às experiências afetivo-sexuais}

- Você namora? Há quanto tempo? Como você caracterizaria o relacionamento? (Em caso de resposta negativa, investigar o motivo)

- E os relacionamentos anteriores, como você os caracterizaria? (Investigar temas como: desejo de intimidade, grau de satisfação, planos futuros, motivos do término da relação)

- Já teve relações sexuais? Com que idade iniciou essas atividades? 
- Como você percebe essas atividades atualmente? (Investigar questões relacionadas a prazer e ocorrência de orgasmo)

- Você percebe alguma dificuldade na área da sexualidade?

- Como você acha que seu parceiro se sente com o relacionamento de vocês? (Investigar de forma mais aprofundada as questões sexuais)

- Você acredita que o transtorno alimentar tenha alguma relação com a sua sexualidade?

\section{Informações relativas à vivência familiar}

- Como você caracterizaria a relação que você mantém com seus pais?

- Com quantos anos você teve sua primeira menstruação? Como você se sentiu nessa época?

- Como seus pais reagiram frente à sua menarca? E como você se sentiu frente à reação deles?

- O sexo era um assunto conversado em família?

- Conte-me a respeito da época em que você começou a se interessar por namoro: você compartilhou esse interesse com seus pais? Como eles reagiram? O que isso fez você sentir?

- Quanto às suas primeiras relações sexuais: você contou aos seus pais? Como eles reagiram? (Em caso de resposta negativa, investigar o motivo)

- Você considera que seus pais gostam de ter uma filha do sexo feminino? Por quê?

\section{Desfecho da entrevista}

- Conte-me como foi para você participar desta pesquisa.

- Você acha que teria mais algum assunto que nós poderíamos conversar para compreender esse tema?

- Haveria outras questões que você julga importantes e que, em sua opinião, seria importante eu saber para compreender a percepção que você tem da sua sexualidade?

- Por favor, escolha um nome que eu possa utilizar para referir-me a você na pesquisa. 


\section{Apêndice II - Roteiro de Entrevista Semiestruturada}

\section{MÃES E PAIS}

\section{Dados sociodemográficos:}

Nome:

Nome da filha acometida:

Naturalidade:

Procedência:

Idade: Nível de escolaridade:

Ocupação:

Situação conjugal: Filhos: ( ) sim

( ) não

Quantos:

Renda familiar:

$\mathrm{N}^{\mathrm{o}}$ de pessoas que moram na residência:

Tipo de moradia (própria, alugada, emprestada):

Religião: Praticante: ( ) sim ( ) não Frequência semanal:

\section{Informações acerca do transtorno alimentar}

- Atualmente, quais são as dificuldades de sua filha com a alimentação?

- Desde quando você percebe que isso vem acontecendo?

- Há algum fator que você associa com o início da ocorrência do transtorno? Por quê?

\section{Situação emocional da filha}

- Depois que o transtorno alimentar começou, que sentimentos você considera que sua filha passou a experimentar com mais frequência? Como está hoje? (Investigar a que comportamentos esses sentimentos estão associados)

- Qual são as principais dificuldades que você passou a enfrentar após a instalação do quadro de sua filha?

- O que faz para enfrentar suas dificuldades? O que ajuda a amenizar esses problemas? Em que situações essa ajuda traz bons resultados?

- Como você caracterizaria o seu papel de mãe/pai de uma filha com transtorno alimentar? Em que implica esse papel?

\section{Informações relativas à vivência familiar e às experiências afetivo-sexuais da filha}

- Como você caracterizaria a relação que você mantém com sua filha?

- Com quantos anos ela teve sua primeira menstruação? Como você se sentiu nessa época? 
- Quando sua filha começou a desenvolver os atributos de um corpo feminino, como foi para você?

- Conte-me a respeito da época em que sua filha começou a se interessar por namoro: ela compartilhou esse interesse com você? Como você reagiu? O que isso fez você sentir?

- Quanto às primeiras relações sexuais de sua filha: ela contou a você? Como você reagiu? (Em caso de resposta negativa, investigar o motivo)

- E hoje em dia, como você lida com as relações afetivas e sexuais de sua filha?

- O sexo é algo conversado em família? Como são essas conversas? (Em caso de resposta negativa, investigar o motivo)

- Como você se sente tendo uma filha do sexo feminino? Por quê?

\section{Desfecho da entrevista}

- Conte-me como foi para você participar desta pesquisa.

- Você acha que teria mais algum assunto que nós poderíamos conversar para compreender esse tema?

- Haveria outras questões que você julga importantes e que, em sua opinião, seria importante eu saber para compreender a percepção que você tem da sua sexualidade e da sexualidade de sua filha?

- Por favor, escolha um nome que eu possa utilizar para referir-me a você na pesquisa. 


\section{Apêndice III}

\section{Termo de Consentimento Livre e Esclarecido}

\section{(PACIENTES acima de 18 anos)}

Eu me chamo Carolina Leonidas, sou estudante do programa de pós-graduação em Psicologia da Universidade de São Paulo (USP) e estou realizando uma pesquisa de Doutorado com a finalidade de investigar as vivências relacionadas com a sexualidade e feminilidade de mulheres com transtornos alimentares.

Esta pesquisa está sendo desenvolvida sob orientação do Prof. Dr. Manoel Antônio dos Santos, pesquisador vinculado ao LEPPS - Laboratório de Ensino e Pesquisa em Psicologia da Saúde da Faculdade de Filosofia, Ciências e Letras de Ribeirão Preto - USP. Este estudo foi aprovado pelo Comitê de Ética em Pesquisa (CEP) da referida faculdade, o que significa que o projeto está de acordo com as normas e princípios éticos que regulamentam as pesquisas com seres humanos. Caso necessário, você pode entrar em contato com o CEP da FFCLRP-USP pelo telefone: (16) 3062-4811 ou pelo e-mail coetp@ffclrp.usp.br ou ainda pessoalmente, na sala 16 do Bloco 3, de segunda a terça-feira das 8 às 17 horas.

Faz parte do estudo conhecer um pouco da história de cada participante por meio de uma conversa individual, que deve durar cerca de 60 minutos. Você poderá falar à vontade a respeito dos temas que lhe forem colocados.

Caso esteja de acordo, você participará de uma entrevista, que abordará questões relativas ao transtorno alimentar, às relações afetivo-sexuais que você estabeleceu ao longo de sua vida ao relacionamento entre você e sua família. Eu também irei conversar com seus pais, para compreender as questões mencionadas a partir de vários pontos de vista, pois isso favorece a profundidade da pesquisa. É importante dizer que nada do que você informar durante a entrevista será divulgado, nem comentado com seus pais.

A entrevista permite o aprofundamento em determinado tema de pesquisa, indo além de uma conversa superficial para alcançar uma rica discussão a respeito de seus pensamentos e sentimentos. A partir da relação estabelecida pela entrevistadora com a pessoa entrevistada, a entrevista pode ser compreendida como um diálogo dinâmico e mútuo, no qual ocorrem interações e trocas entre as partes, e de onde podem surgir os sentidos e significados da experiência investigada. A entrevistadora introduz o tema e a pessoa entrevistada tem liberdade para discorrer sobre ele, podendo assim explorar amplamente a questão. 
Como já mencionado anteriormente, seus pais também serão convidados a participar desta pesquisa. As entrevistas serão realizadas individualmente, em sala reservada da instituição hospitalar e com condições apropriadas de conforto e privacidade. Caso seja necessário, poderemos agendar os encontros fora do contexto hospitalar, de acordo com sua disponibilidade e de seus pais.

Eu gravarei essa conversa, se for permitido por você. O motivo de estar gravando é para não se perder nada do que me for dito, evitando passar despercebido algum detalhe importante. Tudo o que você me disser somente será utilizado para esse tipo de estudo e você não será identificada em momento algum, podendo até escolher um outro nome (fictício), caso desejar, com o qual você gostaria que eu a identificasse nesse estudo. Mesmo depois de começarmos a pesquisa você poderá desistir a qualquer momento de participar do estudo, caso não concorde ou não se sinta mais à vontade para prosseguir, sem que isso traga prejuízo para a continuidade do seu atendimento junto ao serviço.

Ao aceitar participar desse estudo você estará contribuindo para que se saiba mais sobre a relação entre a vivência da sexualidade e os transtornos alimentares, bem como os sentimentos e necessidades emocionais das pessoas que são atendidas neste serviço (Grupo de Assistência em Transtornos Alimentares do Ambulatório de Nutrologia do HC-FMRP-USP) e, com isso, os profissionais poderão ajudar melhor você e outras pessoas que estão sendo atendidas.

Você não corre nenhum risco significativo ao participar dessa pesquisa. Caso você experimente algum tipo de desconforto psicológico, poderá conversar com a equipe de Psicologia do serviço, composta por psicólogos e estagiários de Psicologia. Eventuais despesas que você tiver para participar desse estudo serão ressarcidas pela pesquisadora. A entrevista será agendada em um dos dias de seu retorno ao serviço, ou em algum outro dia e lugar que você considerar mais conveniente.

Diante do exposto, declaro que estou ciente das informações recebidas e que concordo voluntariamente em participar dessa pesquisa, recebendo uma cópia desse Termo, o que me permitirá entrar em contato com os pesquisadores em algum outro momento, caso eu deseje ou sinta necessidade de obter novos esclarecimentos a respeito desta pesquisa. 
Ribeirão Preto de de $201 \ldots$

Nome da participante:

Assinatura da participante:....

Assinatura da pesquisadora-responsável:

Fones para contato:

(16) 99163-8929 (Carolina Leonidas, pesquisadora-responsável).

(16) 36023645 (Prof. Dr. Manoel Antônio dos Santos), de 2a a 6a feira, das 8h às 17h.

Endereço: NEPPS - FFCLRP-USP. Departamento de Psicologia e Educação. Centro de Psicologia e Pesquisa Aplicada. Bloco 5. Av. Bandeirantes, 3900, Monte Alegre, 14040-901 Ribeirão Preto-SP. 


\section{Apêndice IV}

\section{Termo de Consentimento Livre e Esclarecido}

\section{(pais ou responsáveis legais de pacientes menores de 18 anos)}

Eu me chamo Carolina Leonidas, sou estudante do programa de pós-graduação em Psicologia da Universidade de São Paulo (USP) e estou realizando uma pesquisa de Doutorado com a finalidade de investigar as vivências relacionadas com a sexualidade e feminilidade de mulheres com transtornos alimentares.

Essa pesquisa está sendo desenvolvida sob orientação do Prof. Dr. Manoel Antônio dos Santos, pesquisador vinculado ao LEPPS - Laboratório de Ensino e Pesquisa em Psicologia da Saúde da Faculdade de Filosofia, Ciências e Letras de Ribeirão Preto-USP. Este estudo foi aprovado pelo Comitê de Ética em Pesquisa (CEP) da referida faculdade, o que significa que o projeto está de acordo com as normas e princípios éticos que regulamentam as pesquisas com seres humanos. Caso necessário, você pode entrar em contato com o CEP da FFCLRP-USP pelo telefone: (16) 3062-4811 ou pelo e-mail coetp@ffclrp.usp.br, ou ainda pessoalmente, na sala 16 do Bloco 3 , de segunda a terça-feira das 8 às 17 horas.

Faz parte do estudo conhecer um pouco da história de cada participante por meio de uma conversa individual, que deve durar cerca de 60 minutos. Caso esteja de acordo que a sua filha participe do estudo, eu realizarei com ela uma entrevista que abordará questões sobre o transtorno alimentar, as relações afetivo-sexuais que ela estabeleceu ao longo da vida e as relações entre ela e a família. Eu gravarei essa conversa, se for permitido por ela. O motivo de estar gravando é para não se perder nada do que me for dito, evitando que algum detalhe importante passe despercebido.

A entrevista permite o aprofundamento no tema da pesquisa, indo além de uma conversa superficial, pois se pretende fomentar uma rica discussão a respeito de pensamentos e sentimentos. A partir da relação entre a entrevistadora e o entrevistado, a entrevista pode ser compreendida como um diálogo dinâmico e mútuo, no qual ocorrem interações e trocas entre as partes, e de onde podem surgir os sentidos e significados da experiência investigada. A entrevistadora introduz o tema e a pessoa entrevistada tem liberdade para discorrer sobre ele, podendo, assim, explorar amplamente a questão.

Ao ser selecionada para participar deste estudo, sua filha será informada de que você e seu marido/sua esposa também serão convidados a participarem. As entrevistas serão realizadas individualmente, em sala reservada da instituição hospitalar e com condições 
apropriadas de conforto e privacidade. Caso seja necessário, poderemos agendar os encontros fora do contexto hospitalar, de acordo com a disponibilidade dos participantes. Após anuência por meio da assinatura deste TCLE, os participantes serão entrevistados seguindo um roteiro de entrevista previamente elaborado, e poderão falar à vontade a respeito dos temas que lhe forem colocados.

Tudo o que sua filha me disser somente será utilizado para fins deste estudo e ela não será identificada em momento algum, podendo até escolher um outro nome (fictício) caso desejar, com o qual ela gostaria que eu a identificasse nesse estudo. Mesmo depois de começarmos a pesquisa ela poderá desistir a qualquer momento de participar do estudo, caso não concorde ou não se sinta mais à vontade para prosseguir, sem que isso traga prejuízo para a continuidade do atendimento dela junto ao serviço.

Ao concordar com a participação de sua filha neste estudo você estará contribuindo para que se saiba mais sobre a relação entre a vivência da sexualidade e os transtornos alimentares, bem como os sentimentos e necessidades emocionais das pessoas que são atendidas no serviço (Grupo de Assistência em Transtornos Alimentares do Ambulatório de Nutrologia do HC-FMRP-USP). Com essas informações, os profissionais poderão ajudar melhor outras pessoas que estão sendo atendidas e seus familiares.

Sua filha não corre nenhum risco significativo ao participar desta pesquisa. Caso experimente algum tipo de desconforto psicológico, ela poderá conversar com a equipe de Psicologia do serviço, composta por psicólogos e estagiários de Psicologia. Eventuais despesas que ela tiver para participar deste estudo serão ressarcidas pelos pesquisadores. A entrevista será agendada em um dia de retorno ao serviço, ou em algum outro dia e local que ela e vocês considerarem mais conveniente.

Diante do exposto, declaro que estou ciente das informações recebidas e que concordo voluntariamente que minha filha participe desta pesquisa, recebendo uma cópia desse Termo, o que me permitirá entrar em contato com os pesquisadores em algum outro momento, caso eu deseje ou sinta necessidade de obter novos esclarecimentos a respeito desta pesquisa.

Ribeirão Preto de de $201 \ldots$ 
Nome da mãe/pai/responsável:

Assinatura da mãe/pai/responsável:

Assinatura da pesquisadora-responsável:

Fones para contato:

(16) 99163-8929 (Carolina Leonidas, pesquisadora-responsável).

(16) 36023645 (Prof. Dr. Manoel Antônio dos Santos), de 2 a $6^{\mathrm{a}}$ feira, das 8h às 17h.

Endereço: NEPPS - FFCLRP-USP. Departamento de Psicologia e Educação. Centro de Psicologia e Pesquisa Aplicada. Bloco 5. Av. Bandeirantes, 3900, Monte Alegre, 14040-901 Ribeirão Preto-SP. 


\section{Apêndice V \\ Termo de Consentimento Livre e Esclarecido \\ (MÃES E PAIS)}

Eu me chamo Carolina Leonidas, sou estudante do programa de pós-graduação em Psicologia da Universidade de São Paulo (USP) e estou realizando uma pesquisa de Doutorado com a finalidade de investigar as vivências relacionadas com a sexualidade e feminilidade de mulheres com transtornos alimentares.

Esta pesquisa está sendo desenvolvida sob orientação do Prof. Dr. Manoel Antônio dos Santos, pesquisador vinculado ao LEPPS - Laboratório de Ensino e Pesquisa em Psicologia da Saúde da Faculdade de Filosofia, Ciências e Letras de Ribeirão Preto - USP. Este estudo foi aprovado pelo Comitê de Ética em Pesquisa (CEP) da referida faculdade, o que significa que o projeto está de acordo com as normas e princípios éticos que regulamentam as pesquisas com seres humanos. Caso necessário, você pode entrar em contato com o CEP da FFCLRP-USP pelo telefone: (16) 3062-4811 ou pelo e-mail coetp@ffclrp.usp.br, ou ainda pessoalmente, na sala 16 do Bloco 3, de segunda a terça-feira das 8 às 17 horas.

Faz parte do estudo conhecer um pouco da relação dos pais com a filha acometida por transtorno alimentar por meio de uma conversa individual, que deve durar cerca de 60 minutos. Caso esteja de acordo, você participará de uma entrevista que abordará questões sobre o transtorno alimentar de sua filha, aspectos das relações afetivo-sexuais que ela estabelece em sua vida, a forma como você - em seu papel de mãe/pai - lida com essas questões afetivo-sexuais e, por fim, as relações entre você e sua filha de uma forma geral. Eu também irei conversar com a sua filha e com seu/sua marido/esposa, para compreender as questões mencionadas a partir de vários pontos de vista, favorecendo maior profundidade da pesquisa.

A entrevista permite o aprofundamento no tema da pesquisa, indo além de uma conversa superficial, pois se pretende fomentar uma rica discussão a respeito de pensamentos e sentimentos. A partir da relação entre a entrevistadora e o entrevistado, a entrevista pode ser compreendida como um diálogo dinâmico e mútuo, no qual ocorrem interações e trocas entre as partes, e de onde podem surgir os sentidos e significados da experiência investigada. A entrevistadora introduz o tema e a pessoa entrevistada tem liberdade para discorrer sobre ele, podendo, assim, explorar amplamente a questão. 
Ao ser selecionada para participar deste estudo, sua filha será informada de que você e seu marido/sua esposa também serão convidados a participarem. As entrevistas serão realizadas individualmente, em sala reservada da instituição hospitalar e com condições apropriadas de conforto e privacidade. Caso seja necessário, poderemos agendar os encontros fora do contexto hospitalar, de acordo com a sua disponibilidade. Após sua anuência por meio da assinatura deste TCLE, você será entrevistada(o) seguindo um roteiro de entrevista previamente elaborado, e poderá falar à vontade a respeito dos temas que lhe forem colocados.

Nada do que você me disser será transmitido a sua filha ou ao seu cônjuge. Eu gravarei essa conversa, se for permitido por você. O motivo de estar gravando é para não se perder nada do que me for dito, evitando que algum detalhe importante passe despercebido. Tudo o que você me disser somente será utilizado para os fins deste estudo e nem você não será identificado(a) em momento algum, podendo até escolher um outro nome (fictício), caso desejar, com o qual você gostaria que eu a(o) identificasse nesse estudo. Mesmo depois de começarmos a pesquisa você poderá desistir a qualquer momento de participar do estudo, caso não concorde ou não se sinta mais à vontade para prosseguir, sem que isso traga prejuízo para a continuidade do atendimento de sua filha junto ao serviço.

Ao aceitar participar deste estudo você estará contribuindo para que se saiba mais sobre a relação entre a vivência da sexualidade e os transtornos alimentares, bem como os sentimentos e necessidades emocionais das pessoas que são atendidas neste serviço (Grupo de Assistência em Transtornos Alimentares do Ambulatório de Nutrologia do HC-FMRP-USP) e, com isso, os profissionais poderão ajudar melhor sua filha e outras pessoas que estão sendo atendidas.

Você não corre nenhum risco significativo ao participar desta pesquisa. Caso você experimente algum tipo de desconforto psicológico, poderá conversar com a equipe de Psicologia do serviço, composta por psicólogos e estagiários de Psicologia. Eventuais despesas que você tiver para participar deste estudo serão ressarcidas pela pesquisadora. A entrevista será agendada em um dos dias de retorno de sua filha ao serviço, ou em algum outro dia e local que você considerar mais conveniente.

Diante do exposto, declaro que estou ciente das informações recebidas e que concordo voluntariamente em participar dessa pesquisa, recebendo uma cópia desse Termo, o que me permitirá entrar em contato com os pesquisadores em algum outro momento, caso eu deseje ou sinta necessidade de obter novos esclarecimentos a respeito desta pesquisa. 
Ribeirão Preto de de $201 \ldots$

Nome do(a) participante:

Assinatura do(a) participante:

Assinatura da pesquisadora-responsável:

Fones para contato:

(16) 99163-8929 (Carolina Leonidas, pesquisadora-responsável).

(16) 36023645 (Prof. Dr. Manoel Antônio dos Santos), de 2a a $6^{\mathrm{a}}$ feira, das 8h às 17h. Endereço: NEPPS - FFCLRP-USP. Departamento de Psicologia e Educação. Centro de Psicologia e Pesquisa Aplicada. Bloco 5. Av. Bandeirantes, 3900, Monte Alegre, 14040-901 Ribeirão Preto-SP. 